Rômulo da Silva Farias

\title{
ESTUDO TEÓRICO-EXPERIMENTAL DO EFEITO DA LAJE NA TRANSFERÊNCIA DE FORÇAS EM LIGAÇÕES VIGA-PILAR MISTO PREENCHIDO
}

Dissertação apresentada à Escola de Engenharia de São Carlos, da Universidade de São Paulo, como parte integrante dos requisitos para obtenção do título de Mestre em Engenharia de Estruturas.

Orientadora: Ana Lúcia H. de Cresce El Debs

São Carlos 
AUTORIZO A REPRODUÇÃO E DIVULGAÇ̃̃O TOTAL OU PARCIAL DESTE TRABALHO, POR QUALQUER MEIO CONVENCIONAL OU ELETRÔNICO, PARA FINS DE ESTUDO E PESQUISA, DESDE QUE CITADA A FONTE.

Ficha catalográfica preparada pela Seção de Tratamento da Informação do Serviço de Biblioteca - EESC/USP

Farias, Rômulo da Silva

Estudo teórico-experimental do efeito da laje na transferência de forças em ligações viga-pilar misto preenchido / Rômulo da Silva Farias ; orientadora Ana Lúcia H. de Cresce El Debs. -- São Carlos, 2008.

Dissertação (Mestrado-Programa de Pós-Graduação e Área de Concentração em Engenharia de Estruturas) -- Escola de Engenharia de São Carlos da Universidade de São Paulo, 2008 .

1. Pilares mistos preenchidos. 2. Ligação viga-pilar. 3. Ligação mista. 4. Estruturas mistas. 5. Aderência açoconcreto.I. Titulo. 
Candidato: Engenheiro RÔMULO DA SILVA FARIAS

Dissertação defendida e julgada em 07/05/2008 perante a Comissão Julgadora:

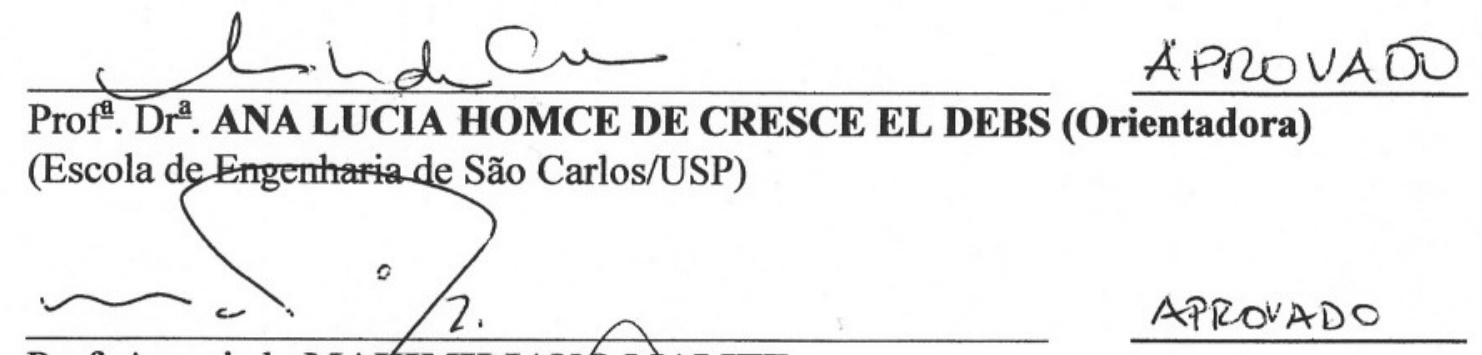

Prof. Associado MAXIMILIANO MALITE

(Escola de Engenharia de São Carlos/USP)

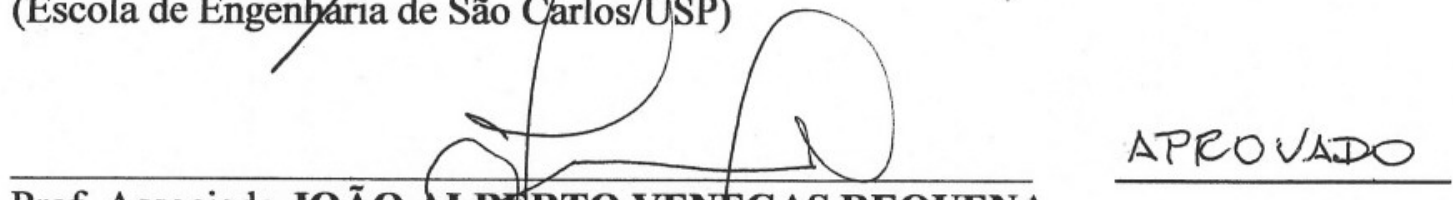

Prof. Associado JOÃo AEBu RTO VENEGAS REQUENA

(Universidade Estadual de Cappinas/UNICAMP)
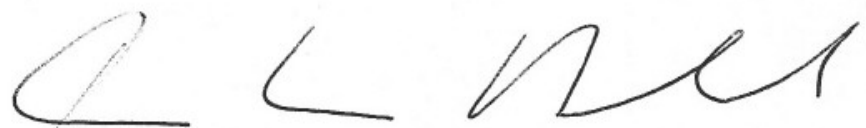

Prof. Associado MARCIO ANTONIO RAMALHO

Coordenador do Programa de Pós-Graduação em

Engenharia Civil (Engenharia de Estruturas)

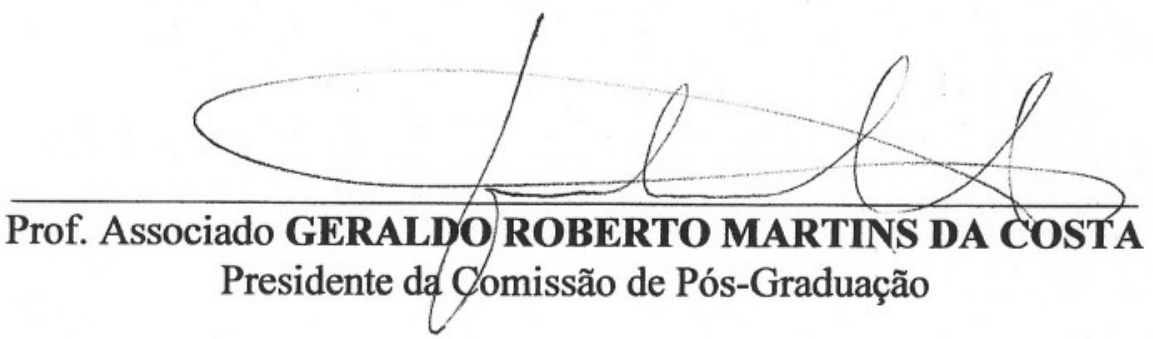


Com muita gratidão e amor, dedico este trabalho aos meus Pais e aos meus irmãos. 


\section{AGRADECIMENTOS}

Agradeço principalmente a Deus e aos meus pais, João e Luzinete, pela ajuda e apoio em todos os momentos necessários e aos meus irmãos André e Kerohlayne.

A todo o povo de Maceió (e do Feitosa), cidade abençoada onde o sol brilha mais forte e o mar é mais azul.

A Prof. Ana Lúcia pela orientação realizada e por sempre estar disposta a auxiliar nas diversas dúvidas ao longo destes dois anos. A sua confiança foi essencial para impulsionar o termino do trabalho.

A Silvana de Nardin pela grande ajuda nas diversas etapas do desenvolvimento do trabalho.

A minha namorada Aline pelo apoio, confiança e compreensão neste momento da minha vida.

Ao meu grande amigo Pedro César, que Deus ilumine o seu caminho e que você continue sendo essa grande pessoa.

Ao amigo Saulo José, que Deus recompense a sua sempre e calma sabedoria e seu grande coração.

Ao amigo Walter Luiz, pela ajuda, conversas e brincadeiras no cafezinho nestes dois anos.

A todos os amigos da comunidade Alagoana em São Carlos e agregados. Dentre eles especialmente ao Netto e ao André Doria.

Aos amigos do curso de mestrado, principalmente ao Antonio, Luiz Aquino, João César, Fabio Yoshio e Rafael Pedrine.

Aos funcionários do Laboratório de estruturas pelo auxílio na etapa experimental do trabalho.

Aos professores Samuel Giongo (USP), Flávio Barboza (UFAL) e Aline Barboza (UFAL), pelos conselhos e apoio dado.

A FAPESP e ao CNPQ pela bolsa concedida e a FAPESP pelo financiamento do projeto. 
"O vento vai para o sul, e faz o seu giro vai para o norte; volve-se e revolve-se na sua carreira, e retoma os seus circuitos. Todos os ribeiros vão para o mar, $e$ contudo o mar não se enche; ao lugar para onde os rios

correm, para ali continuam a correr. Todas as coisas estão cheias de cansaço; ninguém o pode exprimir: os olhos não se fartam de ver, nem os ouvidos se enchem de ouvir. [...]

Porque na muita sabedoria há muito enfado; e o que aumenta o conhecimento aumenta a tristeza."

Eclesiastes 1:6-8, 18 


\section{RESUMO}

FARIAS, R.S. (2008). Estudo teórico-experimental do efeito da laje na transferência de forças em ligações viga-pilar misto preenchido. Dissertação (Mestrado) - Escola de Engenharia de São Carlos, Universidade de São Paulo, São Carlos.

Este trabalho tem como objetivo analisar a influência da laje de concreto armado em uma ligação viga-pilar misto mediante um estudo experimental e uma modelagem numérica. A ligação considerada é constituída por uma viga de aço unida a um pilar misto preenchido através de barras rosqueadas que trabalham como parafusos passantes. Esse tipo de ligação já foi investigado em trabalhos anteriores, mediante análise experimental em modelos que não incluíam a laje, resultando em uma indesejável ruptura dos parafusos. A análise da ligação completa, com a presença da laje de concreto tornando a ligação uma ligação mista, além de ser mais realista, melhora as características de resistência e rigidez do modelo, além de tornar mais dúctil o seu comportamento. Para isso foram analisados três modelos experimentais que se diferenciam pela ausência ou tipo de conector de cisalhamento presente na região interna do pilar misto. Os resultados obtidos mostraram que a ruptura da ligação passou a ser determinada pela laje, associada ao escoamento da armadura longitudinal sem que a ligação viga-pilar fosse comprometida. Para a análise numérica foi utilizado o pacote computacional DIANA ${ }^{\circledR}$, baseado no método dos elementos finitos. Os modelos numéricos foram desenvolvidos e calibrados pelos resultados experimentais, produzindo resultados bastante satisfatórios. Finalmente foi realizada uma análise numérica paramétrica variando a armadura longitudinal da laje e a resistência do concreto com o objetivo de se entender melhor a influência desses parâmetros no comportamento da ligação investigada.

Palavras-chave: Pilares mistos preenchidos, Ligação viga-pilar, Ligação mista, Estruturas mistas, Aderência aço-concreto. 


\section{ABSTRACT}

FARIAS, R.S. (2008). Experimental and theorical analysis of slab effect on the force transfer strength of steel beam to concrete filled columns connection. Dissertação (Mestrado) - Escola de Engenharia de São Carlos, Universidade de São Paulo, São Carlos.

The main objective of this work was to analyze the contribution of the concrete slab for the behavior of a steel beam-concrete filled composite column connection through an experimental program and also a numerical modeling. The considered connection was constituted of steel beams connected to a concrete filled tubular column of rectangular cross section by means of passing bars. This type of connection was studied before through an experimental analysis of connections that did not include the slab, resulting in failure of the passing bars. In the present study, the presence of the slab is considered, turning the connection a composite one. The studied model is more representative of the real structure, and also improves the resistance and the stiffness of the connection, turning the behavior more ductile. Three specimens were tested, where the studied variable was the type of shear connector, angles or stud-bolts, and one specimen without connectors as a reference. The obtained results showed that the failure was determined by the slab, associated to the yielding of the longitudinal reinforcement, without affecting the beam column connection. The finite element based software DIANA ${ }^{\circledR}$ was used to the numerical analysis. The numerical models were developed and calibrated by the experimental results, producing a good agreement. Finally, a parametric analysis was done, varying the slab longitudinal reinforcement and the concrete strength in order to better understand the influence of these parameters in the behavior of the studied connection.

Keywords: Concrete filled collumns, beam-column connection, Composite connection. 


\section{SUMÁRIO}

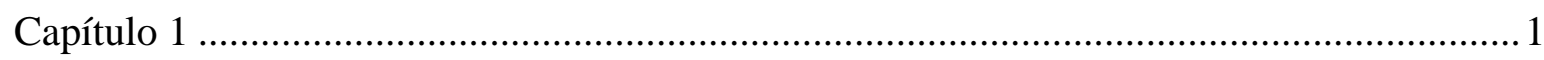

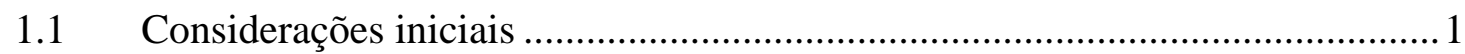

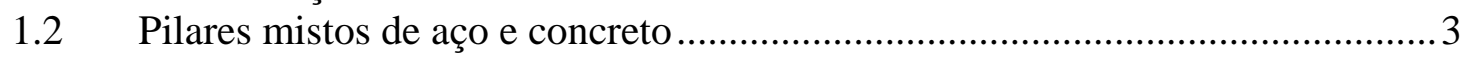

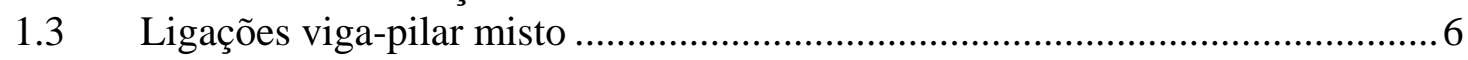

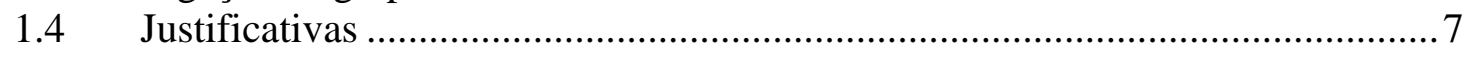

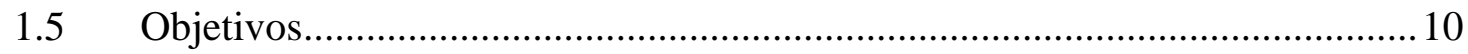

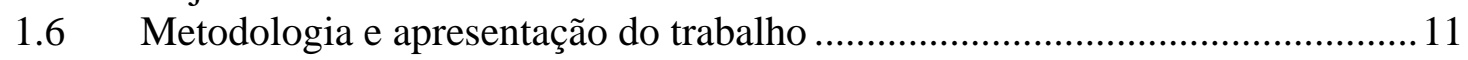

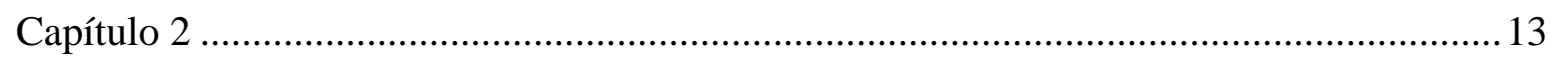

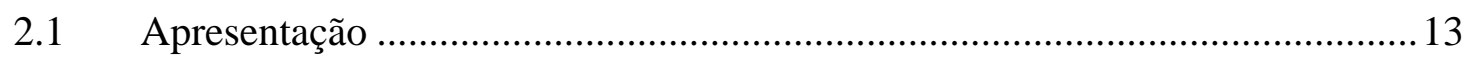

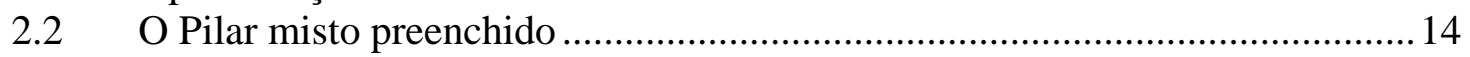

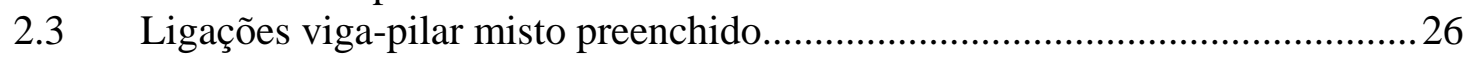

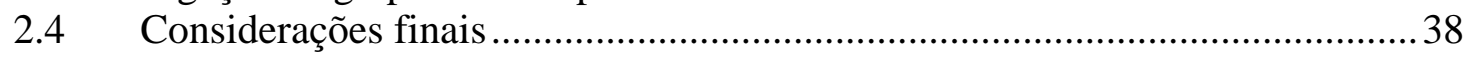

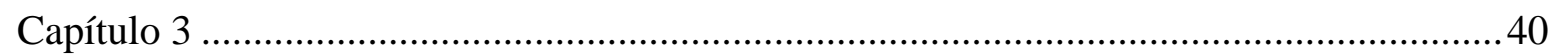

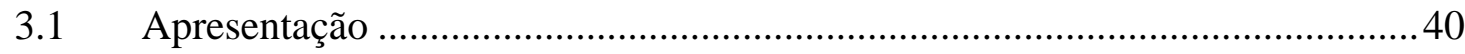

3.2 Importantes aspectos da aderência no pilar misto preenchido .........................41

3.3 Mecanismos de transferência de forças ...................................................... 46

3.4 Aderência nos pilares mistos preenchidos................................................... 49

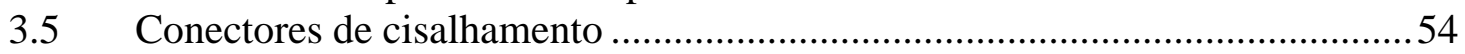

3.6 Modelagem numérica da interface aço-concreto .............................................59

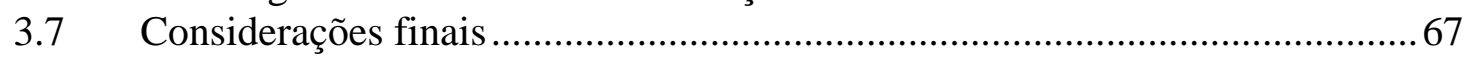

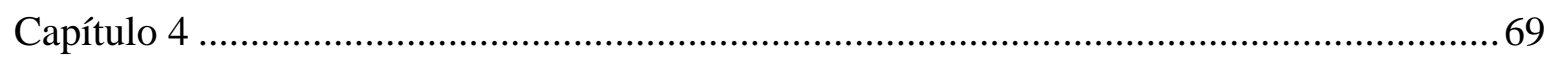

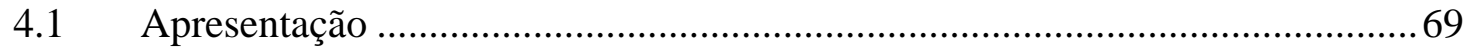

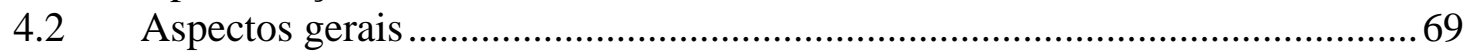

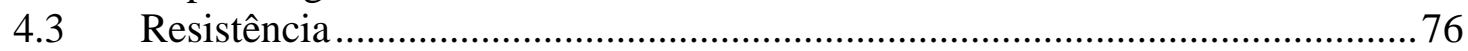

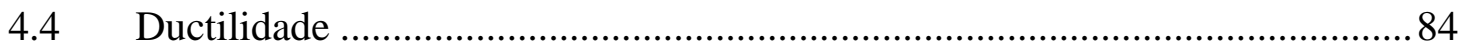

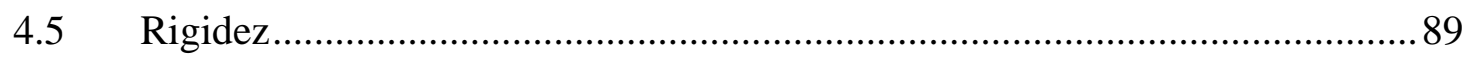

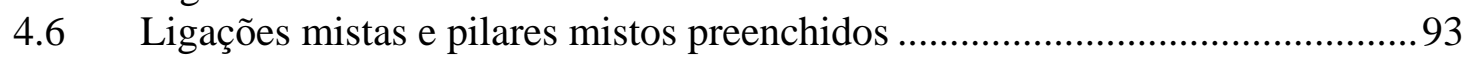

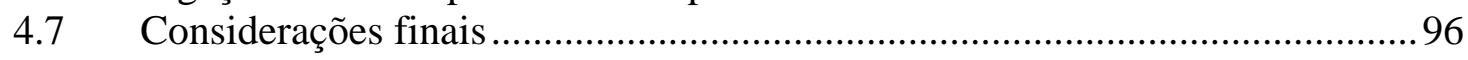

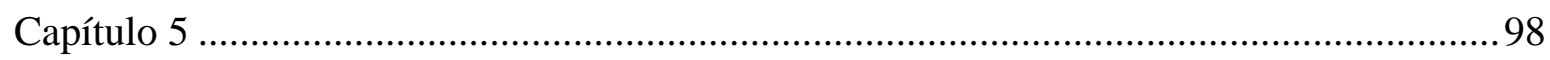

5.1 Apresentação do Programa experimental ...................................................... 98

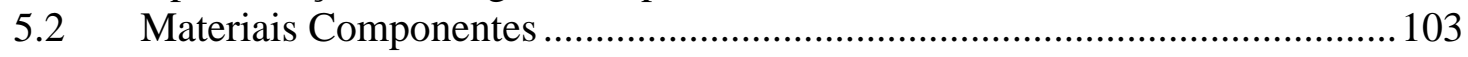

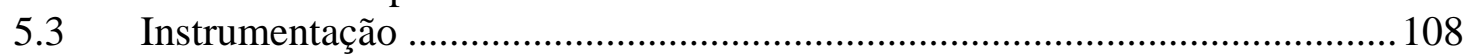

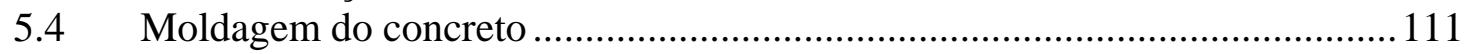

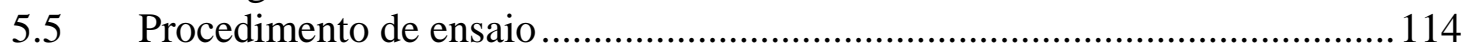

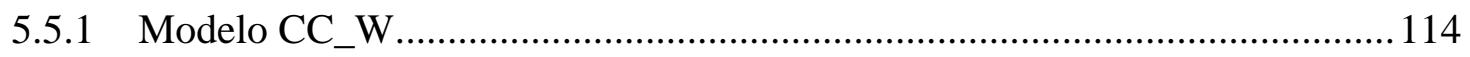

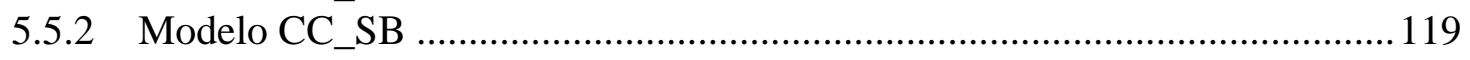

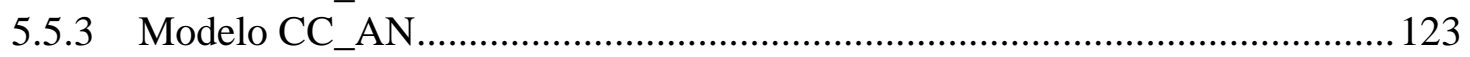

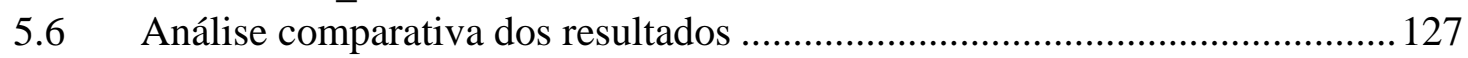

5.6.1 Deformação no núcleo de concreto e no perfil de aço do pilar preenchido ... 127

5.7 Deformações na viga de aço ..................................................................... 131

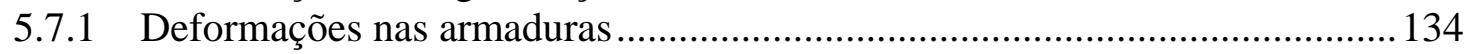

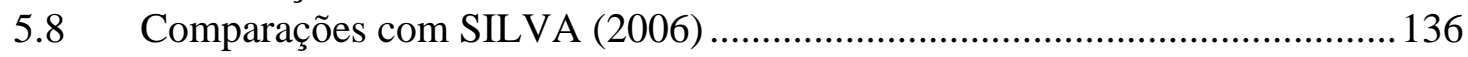

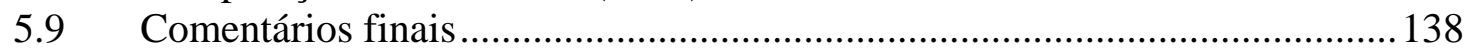




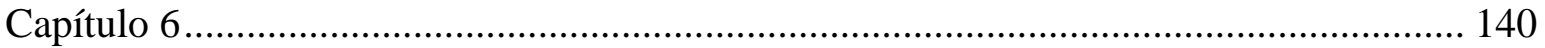

6.1 Apresentação ..................................................................................... 140

6.2 Modelo inicial ....................................................................................... 140

$6.3 \quad$ Elementos finitos.................................................................................. 142

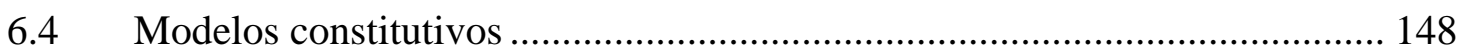

$6.5 \quad$ Modelo numérico final........................................................................... 153

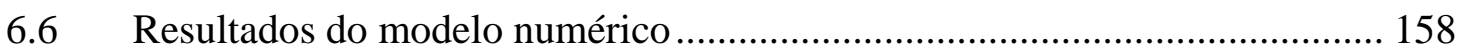

6.7 Análise paramétrica........................................................................................ 167

6.7.1 Análise da influência da taxa de armadura ..................................................... 168

6.7.2 Análise da influência da ancoragem das armaduras ....................................... 171

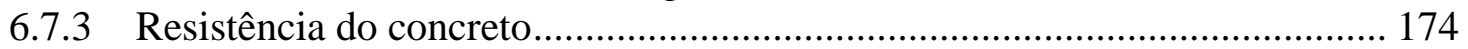

6.8 Considerações finais ................................................................................. 176

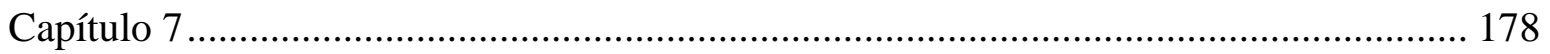

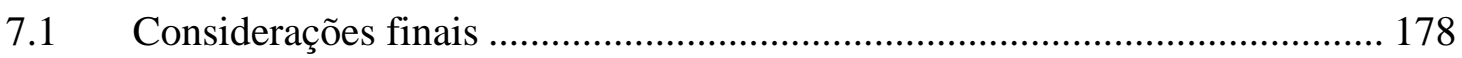

7.1.1 A respeito do tema e da revisão bibliográfica................................................ 178

7.1.2 A respeito da análise experimental ............................................................... 181

7.1.3 A respeito da análise numérica .................................................................... 183

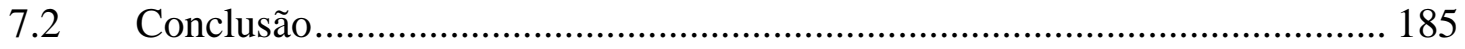

7.3 Sugestões para futuros trabalhos................................................................... 186 


\section{Capítulo 1}

\section{Introdução}

\subsection{Considerações iniciais}

O desenvolvimento da economia e a industrialização criam um ambiente propício para o surgimento de novos sistemas estruturais e de técnicas construtivas inovadoras. Devido aos aspectos técnicos e econômicos, há sempre a tendência de associar o concreto com o aço formando um elemento estrutural único. Essa associação é mais comum nas estruturas de concreto armado, mas nas últimas décadas o seu uso também acontece com freqüência nas estruturas mistas de aço e concreto.

Elementos mistos de aço e concreto são geralmente definidos como a união de um perfil metálico e um elemento de concreto, de forma que os dois materiais trabalhem em conjunto, formando assim um único elemento estrutural.

A filosofia das estruturas mistas é baseada na utilização dos materiais de forma que sejam aproveitadas as vantagens de ambos e que as suas desvantagens sejam minimizadas. Para que os dois materiais trabalhem de forma conjunta, é necessário promover sua interação a partir do uso de conectores de cisalhamento ou com a simples consideração da aderência e do atrito entre os componentes da seção mista.

Os tipos de elementos mistos de aço e concreto utilizados comumente são vigas mistas, pilares mistos, lajes mistas e ligações mistas.

Nos últimos anos os sistemas mistos de aço e concreto têm sido utilizados com mais freqüência, principalmente nos países mais industrializados localizados na Europa e na Ásia. 
A Figura 1-1 mostra exemplos de edifícios construídos utilizando sistemas mistos ou algum elemento misto de aço e concreto.

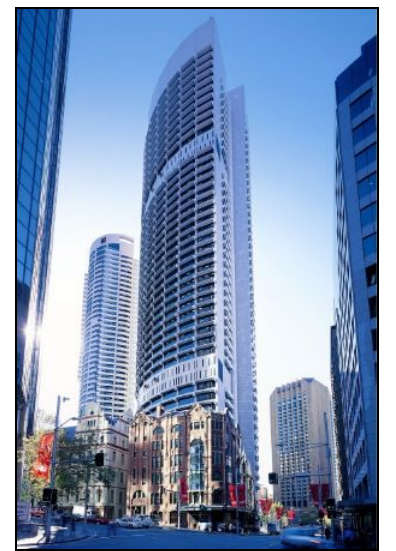

a) Grosvenor Place - Sidney, Austrália. Pilares mistos revestidos

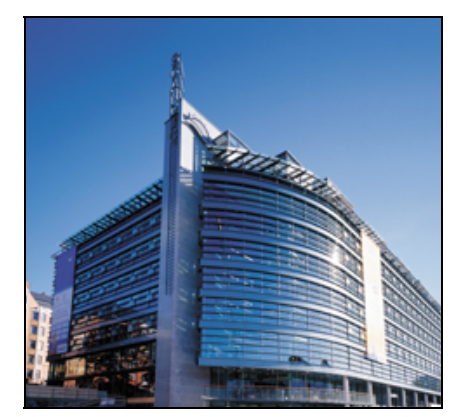

c) Scandic Hotel - Finlândia. Estrutura Híbrida

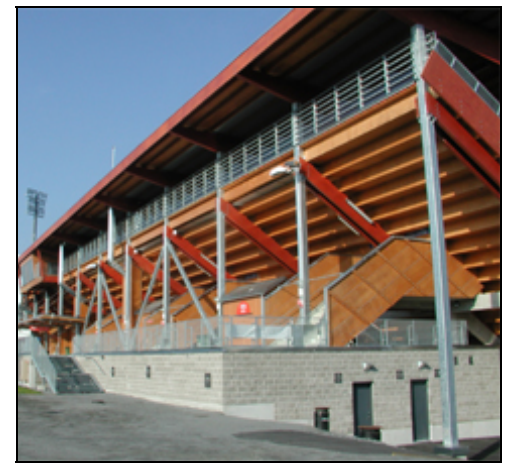

b) Jalkapallon Stadion - Finlândia. Pilares mistos Preenchidos

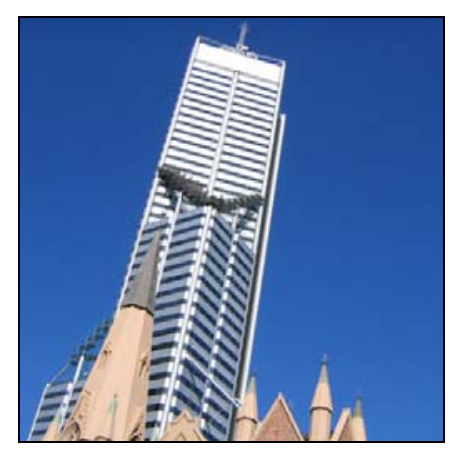

d) Central Park Tower - Perth, Austrália. Estrutura Mista

Figura 1-1 - Exemplos de Edifícios com o uso de elementos mistos de aço e concreto.

O elemento mais comum nas estruturas mistas é a viga mista. A viga mista de aço e concreto é formada por um componente de aço e uma laje de concreto moldada no local ou mista, no qual a laje é apoiada sobre a face superior do perfil metálico. Para que os dois materiais atuem em conjunto na resistência aos esforços de flexão é necessária a introdução de conectores de cisalhamento entre os dois componentes. A Figura 1-2 apresenta exemplos de vigas mistas de aço e concreto. 

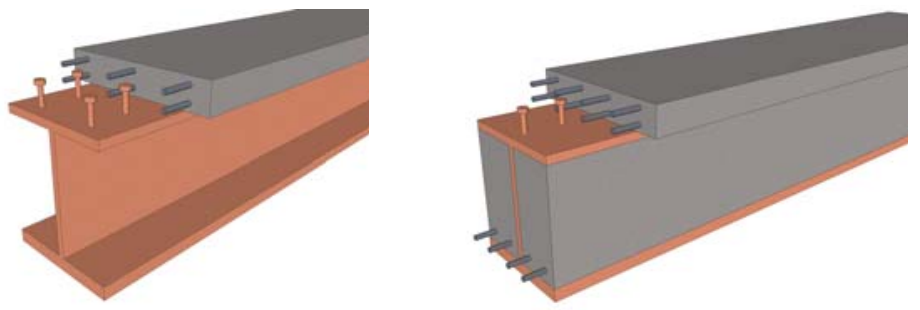

Figura 1-2 - Vigas mistas de aço e concreto.

As lajes mistas de aço e concreto são constituídas por fôrmas metálicas e concreto, sendo que aquelas atuam como fôrma e como único elemento resistente antes da cura do concreto. A Figura 1-3 mostra dois tipos de lajes mistas.

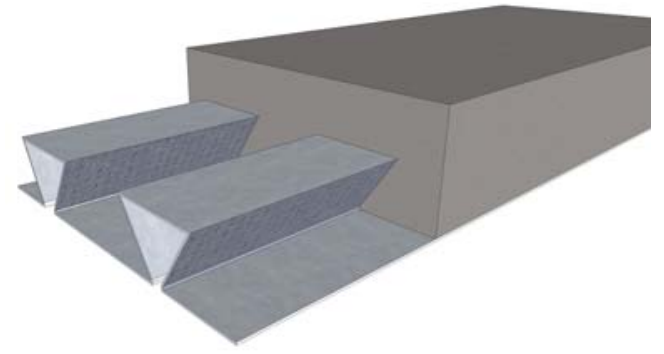

a) Com fôrma reentrante

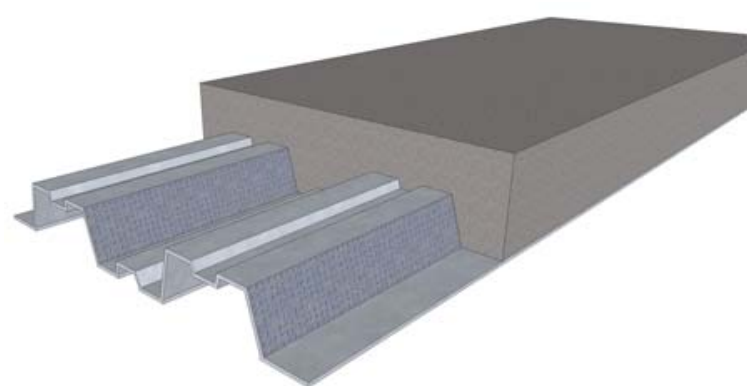

b) Com fôrma trapezoidal

Figura 1-3 - Lajes mistas aço-concreto.

As ligações mistas são aquelas que promovem a participação da laje na transmissão de momento fletor de uma viga mista para um pilar ou para o vão adjacente de outra viga mista.

\subsection{Pilares mistos de aço e concreto}

Pilares mistos de aço e concreto são elementos estruturais formados pela união e trabalho conjunto destes dois materiais, onde os esforços de compressão são predominantes. Os pilares mistos podem ser subdivididos basicamente em dois tipos: os pilares mistos revestidos e os pilares mistos preenchidos, em função do posicionamento do concreto na seção transversal. 
O pilar misto revestido resulta do revestimento ou envolvimento do perfil metálico pelo concreto, podendo ser revestido tanto de forma parcial quanto total. A idéia que deu origem ao pilar misto revestido foi a intenção de proteger o perfil metálico da ação do fogo e de agentes agressivos que possam causar a corrosão do aço. Outro fator importante está no fato do concreto contribuir para a capacidade resistente do elemento estrutural e melhorar o desempenho do perfil isolado quanto a problemas de instabilidade. A Figura 1-4 mostra algumas seções transversais de pilares mistos revestidos.

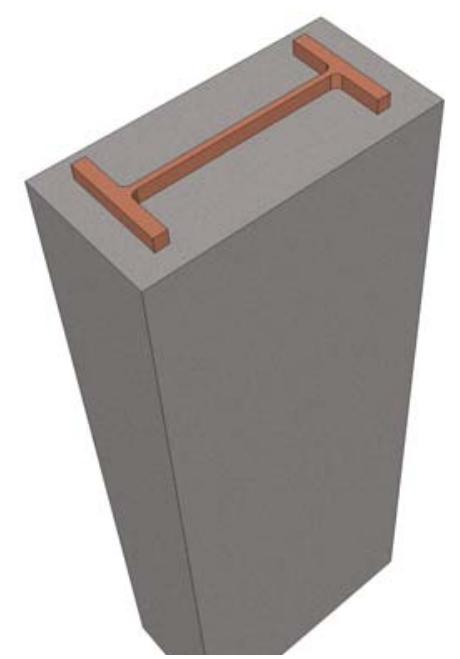

a) Pilar misto com perfil de seção "I" revestido

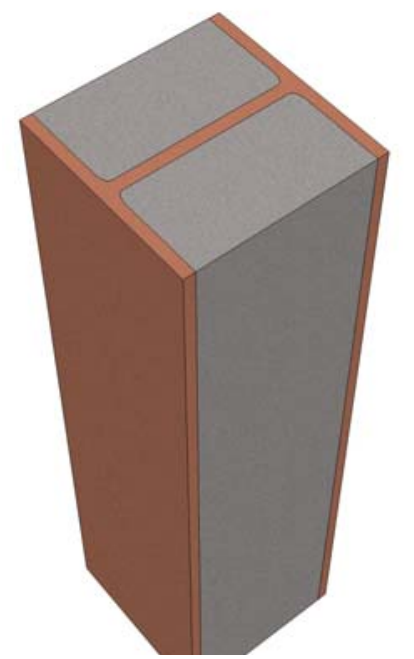

b) Pilar misto parcialmente revestido

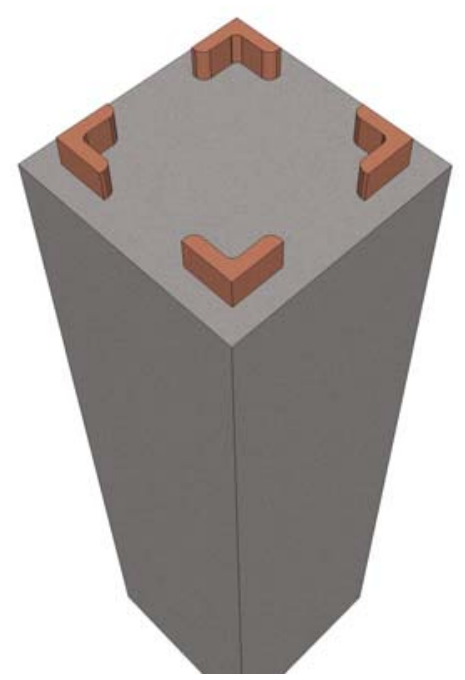

c) Pilar misto revestido, com perfis cantoneira.

Figura 1-4 - Exemplos de pilares mistos revestidos.

Os pilares mistos preenchidos são formados pelo preenchimento de perfis tubulares com concreto estrutural. O tubo metálico serve como fôrma para o concreto e, além de contribuir para resistência do pilar, pode contribuir também para o acréscimo da resistência do concreto devido ao efeito de confinamento. É comum dimensionar o perfil tubular para resistir ao peso próprio e às cargas permanentes e de construção (cargas iniciais que surgirão antes do preenchimento do concreto).

O perfil tubular pode ter diversas geometrias da seção transversal, como circular, retangular e quadrado, e pode ser confeccionado tanto por extrusão como pela soldagem de 
chapas metálicas. O núcleo de concreto do pilar misto aumenta a capacidade resistente da seção e a rigidez do sistema, além do conjunto aço-concreto possibilitar melhora de desempenho em relação ao concreto armado e ao perfil metálico. A Figura 1-5 mostra a geometria de diversas seções transversais de pilares mistos preenchidos.

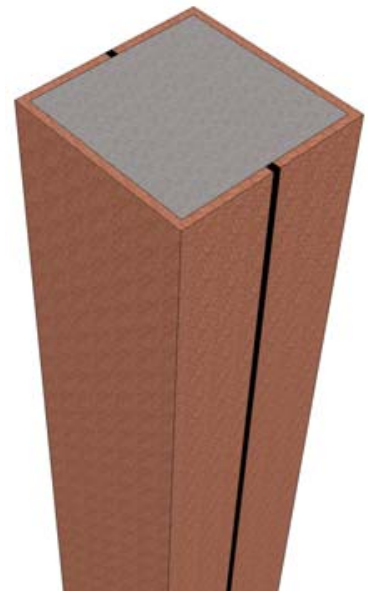

a) Pilar misto de seção quadrada Confeccionado pela soldagem de dois perfis "U".

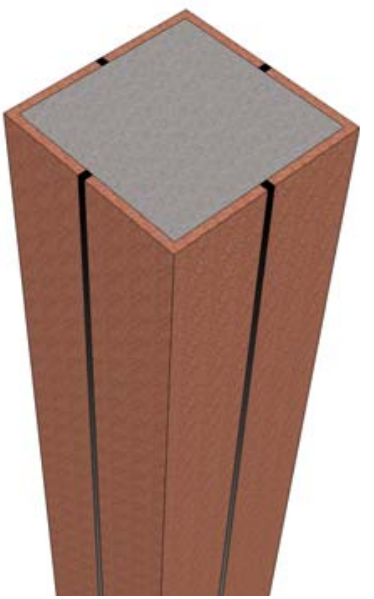

b) Pilar misto de seção quadrada Confeccionado pela soldagem de quatro perfis cantoneiras.

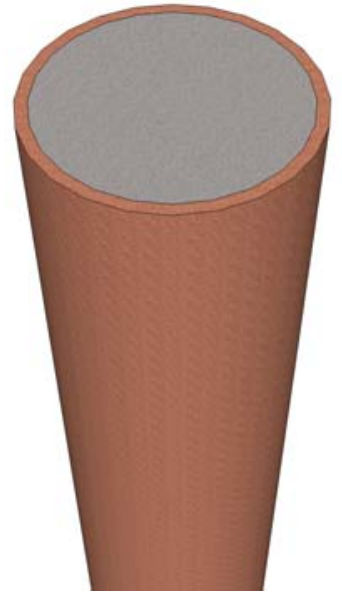

c) Pilar misto de seção circular -

Tubo confeccionado por extrusão

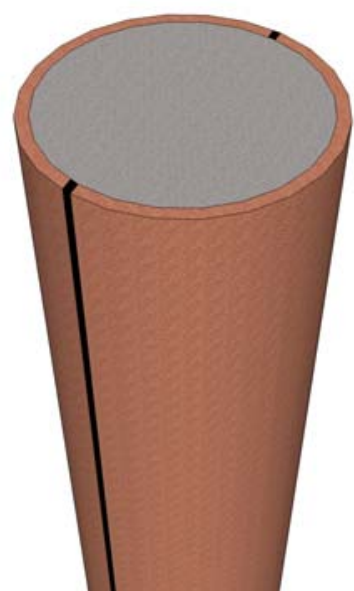

d) Pilar misto de seção circular - Tubo confeccionado por soldagem de chapas

Figura 1-5 - Exemplos de seções de pilares mistos preenchidos.

\subsubsection{Pilares mistos preenchidos}

O uso do pilar misto preenchido começou no final do século 19, utilizados em construções de grande porte e em pontes. Este elemento estrutural torna-se mais atraente em locais onde há a ocorrência de abalos sísmicos, devido a suas propriedades de resistência, ductilidade e capacidade de absorver energia.

O pilar misto preenchido possui propriedades que o tornam interessante para diversas aplicações da Engenharia de Estruturas. Dentre as suas propriedades, pode-se citar a capacidade resistente à compressão, alta capacidade de absorver energia, comportamento dúctil, e um sistema construtivo que permite rapidez de execução, resultando em um processo construtivo racionalizado e com baixo nível de desperdícios. 
É valido citar que outra vantagem do pilar misto preenchido em relação ao concreto armado está no fato de que a dispensa do uso de fôrmas ocasiona a diminuição do desperdício dos materiais, reduzindo o custo total da edificação.

Tabela 1-1 - Vantagens do pilar misto preenchido.

\begin{tabular}{cc}
\hline Vantagens em relação ao concreto armado & $\begin{array}{c}\text { Vantagens em relação às estruturas } \\
\text { metálicas }\end{array}$ \\
\hline Redução do peso próprio & Estabilidade \\
\hline Maior velocidade de construção & Aumento da resistência ao fogo \\
\hline Dispensa de fôrmas & Aumento da resistência à corrosão \\
\hline Dispensa de escoramento & Redução do consumo de aço estrutural \\
\hline Racionalização da construção & -- \\
\hline $\begin{array}{c}\text { Aumento da área útil, devido à redução da seção } \\
\text { transversal. }\end{array}$ & -- \\
\hline
\end{tabular}

A utilização do pilar misto preenchido é mais freqüente em países asiáticos, como o Japão, em alguns países da Europa e na Austrália, o que justifica que os diversos estudos e pesquisas a respeito do tema se concentrem nestes locais.

\subsection{Ligações viga-pilar misto}

Os estudos a respeito das ligações viga-pilar misto preenchido ainda são muito recentes, e novos métodos de promover a ligação entre os dois elementos vêm surgindo nos últimos tempos.

As ligações viga-pilar misto são geralmente subdivididas em dois grandes grupos, as ligações externas e as ligações internas.

As ligações externas consistem na ligação da viga metálica diretamente ao tubo metálico através da soldagem direta de chapas metálicas ou do uso de conectores e parafusos. 
As ligações externas apresentam vantagens em relação a custo e facilidade de execução, mas geralmente são definidas como ligações flexíveis e com baixo desempenho quanto à resistência. O maior problema das ligações externas está na transferência de tensões do tubo de aço para o núcleo de concreto, pois nesta região pode ocorrer concentração de tensões no tubo, prejudicando o desempenho do pilar. Os códigos normativos exigem que, para garantir a transferência de tensões de forma adequada na região de ligação (região de introdução de cargas), deve ser previsto o uso de conectores de cisalhamento no tubo metálico.

As ligações internas são aquelas em que são utilizados dispositivos mecânicos que, inseridos no pilar misto, transferem parte dos esforços diretamente ao núcleo de concreto do pilar. Dentre estes dispositivos, podem ser citadas as chapas metálicas inseridas no tubo metálico, ou a ancoragem de barras de aço e conectores diretamente no núcleo de concreto. Em geral as ligações internas apresentam melhor desempenho que as externas, pois os esforços são distribuídos para os dois componentes do pilar de forma mais uniforme, e algumas ligações internas podem ser consideradas como ligações rígidas, mas o uso das ligações internas acarreta um custo maior em relação ao consumo de material e mão de obra, além de apresentar algumas dificuldades de execução.

\subsection{Justificativas}

Apesar das boas características estruturais e construtivas e da crescente utilização dos pilares mistos preenchidos, alguns aspectos relativos ao seu comportamento estrutural ainda permanecem obscuros e merecem estudos mais aprofundados. Um destes aspectos diz respeito às ligações viga-pilar preenchido e ao mecanismo de transferência de forças dos pavimentos para os pilares. A capacidade resistente da ligação está associada não apenas à sua resistência, mas também à sua capacidade de transferir adequadamente os esforços das vigas 
para o pilar misto, mobilizando o núcleo de concreto, evitando, com isso, que ocorra ruptura local do tubo de aço devido à concentração de tensões.

O método de dimensionamento simplificado para pilares mistos preenchidos, previsto no Projeto de Revisão da NBR 8800 (ABNT, 2007), tem como hipótese a interação completa entre o aço e o concreto, ou seja, a não ocorrência de deslocamento relativo significativo entre os dois materiais. O cisalhamento na superfície de contato entre o perfil de aço e o concreto é tratado de forma diferente na região de introdução de carga e nos trechos intermediários. A região de introdução de carga é considerada como sendo aquela onde são localizadas variações de esforços solicitantes, como em ligações viga-pilar. É prescrito nesta mesma norma que nestas regiões deve-se evitar o escorregamento significativo entre o aço e o concreto, para garantir a transferência de tensões entre os dois materiais evitando assim que a ruína ocorra de forma localizada em apenas um dos componentes. Então, nas ligações vigapilar misto, deve ser verificado se a tensão cisalhante solicitante entre os dois materiais é superior à tensão resistente de cálculo, de forma a evitar o escorregamento relativo. Se a aderência entre os dois materiais não for suficiente para garantir a interação e a transferência de forças, deve ser prevista a inclusão de conectores de cisalhamento nesta região.

Um tipo de ligação viga-pilar misto preenchido proposto inicialmente por Prion e Mclellan (1994) e que apresenta bons resultados de resistência e rigidez foi estudada no Brasil por De Nardin (2004) e Silva (2006). A ligação consiste de barras rosqueadas que transpassam o pilar misto e funcionam como parafusos passantes. A Figura 1-6 ilustra melhor a ligação proposta pelos autores. 

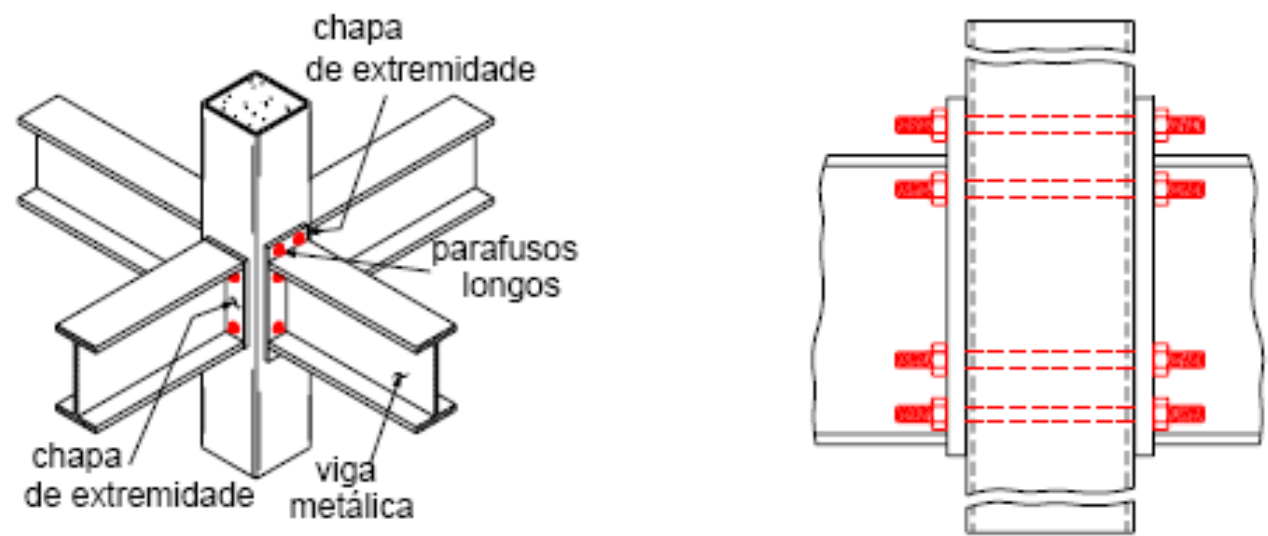

Figura 1-6 - Ligação proposta por Prion e Mclellan (1994).

No estudo realizado por De Nardin (2004) foram analisados aspectos referentes à resistência e à rigidez deste tipo de ligação quando solicitada predominantemente por momento fletor. A ligação mostrou desempenho superior em relação a outros tipos de ligações analisadas no mesmo trabalho.

Em estudo mais recente, Silva (2006) apresentou resultados de ensaios em pilares mistos com e sem a presença de conectores de cisalhamento, estudando o mesmo tipo de ligação com parafusos passantes, mas com ênfase nos esforços de cisalhamento. Os resultados mostraram a eficiência dos conectores na transferência de forças nos modelos de pilares. Entretanto, esses conectores não chegaram a ser completamente mobilizados no ensaio da ligação, já que houve antes a ruptura dos parafusos (Figura 1-7) e o afastamento da chapa de extremidade em relação ao pilar. Estes resultados mostram a importância de melhor se investigar a questão da aderência aço-concreto nos pilares mistos preenchidos e seu papel na transferência de forças das vigas para os pilares.

A laje de concreto armado presente na ligação pode adicionar rigidez e resistência à ligação, melhorando o comportamento geral da mesma. Diversos estudos enfocando a contribuição da laje em ligações viga-pilar começaram a ganhar importância nos últimos anos devido à ocorrência de abalos sísmicos no continente asiático, em que as ligações 
apresentaram um comportamento superior em rigidez e resistência devido à contribuição da laje de concreto armado quando submetida a estes tipos de solicitações.

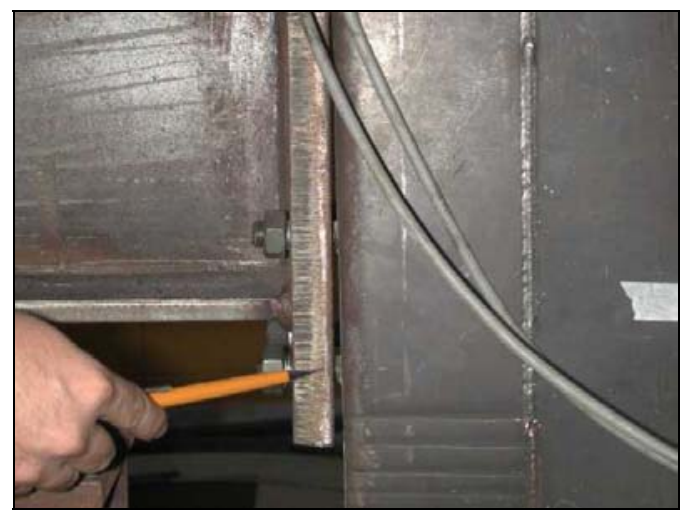

Figura 1-7 - Ruína do modelo experimental verificado por Silva (2006)

Desta forma, para o melhor entendimento do comportamento das ligações viga-pilar misto, torna-se necessário avaliar o papel da laje na transferência de tensões entre os dois materiais, com isso incentivando a utilização de sistemas estruturais com pilares mistos preenchidos.

\subsection{Objetivos}

Conforme comentado anteriormente, os resultados decorrentes de De Nardin (2003) e Silva (2006) revelaram a necessidade de estudos específicos abordando a questão da aderência aço-concreto nas ligações viga-pilar, dada sua importância para o comportamento das estruturas utilizando pilares mistos preenchidos e a carência de resultados sobre o assunto.

Sendo assim, o objetivo principal deste trabalho é investigar as ligações viga de aço pilar misto preenchido, buscando avaliar, sobretudo, a contribuição da laje na transferência de forças do pavimento para o pilar.

Como objetivo específico, coloca-se a investigação dos mecanismos de transferência das forças de cisalhamento das vigas para os pilares mistos preenchidos. Para a melhor 
compreensão desses mecanismos, será ainda investigado o papel de dois tipos de conectores de cisalhamento: os do tipo pino com cabeça e as cantoneiras, sendo o comportamento das ligações com conectores comparados ao de uma ligação de referência, que contará apenas com a aderência aço-concreto para efetivar essa transferência.

Desse modo, acredita-se poder contribuir para a elucidação das questões relativas ao comportamento das ligações envolvendo pilares mistos preenchidos, e com isso tornam a sua utilização mais freqüente e permitindo a incorporação das vantagens inerentes ao sistema construtivo.

\subsection{Metodologia e apresentação do trabalho}

A fim de atingir os objetivos propostos, as atividades foram desenvolvidas por meio de estudos teóricos e investigação experimental, abrangendo 7 capítulos.

A revisão bibliográfica do trabalho foi subdivida em três etapas com o intuito de facilitar o entendimento e a exposição dos trabalhos analisados. Desta forma, no Capítulo 2 são apresentados os diversos aspectos relativos aos pilares mistos preenchidos, sua utilização e comportamento estrutural. No mesmo capítulo são apresentados diversos detalhes de ligação viga-pilar misto preenchido, dando destaque às suas vantagens e desvantagens, sem se prender aos métodos de cálculo destes elementos. No Capítulo 3 são apresentados os diversos aspectos referentes à aderência nos pilares mistos preenchidos e aos mecanismos de transferência de forças. Comenta-se de forma sucinta o papel dos conectores de cisalhamento. Finalmente, são apresentados métodos de implementação da aderência em modelos numéricos, dando ênfase aos elementos de interface. No capítulo 4 são abordadas as ligações mistas, já que a inclusão da laje de concreto ao modelo experimental transforma o modelo numa ligação mista. São abordados aspectos quanto à rigidez, resistência e ductilidade das 
ligações mistas. O papel dos componentes, armaduras, conectores e etc. também são abordados neste capítulo.

A etapa de investigação experimental é apresentada no Capítulo 5, no qual são apresentados os detalhes do modelo experimental analisado, bem como materiais constituintes, dimensões e forma de carregamento, etc. Todas as etapas relevantes da investigação experimental são apresentadas, desde a caracterização dos materiais à instrumentação do modelo. A descrição de cada ensaio é realizada e os resultados de cada modelo são apresentados individualmente. Posteriormente são realizadas comparações entre os resultados de cada modelo considerando ou não a presença dos conectores de cisalhamento. Por fim, os resultados experimentais são comparados com os resultados obtidos por Silva (2006), a fim de avaliar a influência da inclusão da laje no comportamento da ligação.

A análise numérica é abordada no Capitulo 6. Foi utilizado para a análise numérica o método dos elementos finitos, que foi realizada no software DIANA. Inicialmente, são apresentados os tipos de elementos e os modelos constitutivos utilizados no modelo numérico. Após a análise dos resultados do modelo numérico final e a comparação com os resultados experimentais, uma vez validado o modelo numérico, é realizada uma análise paramétrica com o modelo numérico consolidado, com o intuito de investigar parâmetros que não foram avaliados experimentalmente e ampliar as conclusões.

Finalizando, no Capítulo 7 são apresentados os aspectos conclusivos e sugestões para novos trabalhos e pesquisas a respeito do tema. 


\section{Capítulo 2}

\section{Pilar misto e sua ligação viga-pilar}

\subsection{Apresentação}

Este capítulo mostra, de forma geral, as características e o comportamento estrutural dos pilares mistos preenchidos e de alguns detalhes de ligação viga-pilar encontrados nas diversas referências bibliográficas consultadas.

Inicialmente, é apresentado o pilar misto ressaltando suas aplicações e vantagens em relação a outros elementos estruturais. Nesta etapa é descrito o comportamento estrutural do pilar e os modos mais comuns de ruína. Algumas características específicas são ressaltadas como a ductilidade e a capacidade resistente. Posteriormente, são expostas as propriedades específicas dos materiais (aço e concreto) que são relevantes no comportamento do pilar misto, como o confinamento no concreto e a flambagem no tubo de aço.

Os detalhes de ligação viga-pilar misto preenchido também são apresentados. Para facilitar a abordagem, o assunto foi subdividido em ligações externas e ligações internas. Neste tópico, são explorados apenas os tipos de ligação e algumas de suas características relevantes, sem se aprofundar nos métodos de dimensionamento, já que grande parte dos trabalhos encontrados na literatura é de caráter experimental.

Finalmente, são apresentadas algumas considerações a respeito da ligação viga-pilar misto preenchido com parafusos passantes (PRION; MCLELLAN, 1994), que corresponde ao detalhe de ligação analisada no presente trabalho. 


\subsection{O Pilar misto preenchido}

\subsubsection{Introdução}

Os pilares mistos preenchidos são elementos estruturais formados por um componente de aço, podendo ser um perfil tubular retangular ou circular, que é preenchido com concreto estrutural. Podem ser utilizadas armaduras de aço na seção de concreto, para contribuir na capacidade resistente do pilar misto. As características dos dois materiais constituintes contribuem para o comportamento do elemento como um todo, de forma que são exploradas as vantagens de cada material, minimizando suas desvantagens.

As vantagens da utilização dos pilares mistos são referentes ao aproveitamento das propriedades de resistência dos dois materiais (resistência à compressão do concreto e resistência à tração do aço), e da minimização dos problemas referentes aos mesmos materiais (resistência à tração do concreto e estabilidade do perfil de aço). O concreto no interior do tubo minimiza problemas de flambagem no perfil de aço, já o perfil pode aumenta a resistência do concreto devido ao efeito do confinamento. Outras vantagens do pilar misto preenchido é a possibilidade de aumentar o grau de industrialização da construção, já que o tubo de aço serve como fôrma para o concreto.

Diversos tipos de seção transversal podem ser utilizados no pilar misto preenchido mas, em sua maioria, são tubos de aço de seção circular ou quadrada. A confecção do tubo de aço pode ser realizada por composição via soldagem de perfis de aço específicos, ou o tubo pode ser fabricado por extrusão.

A utilização dos pilares mistos preenchidos começou por volta do fim do século 19, em alguns países da Europa. A concepção de que o aço e o concreto atuassem de forma conjunta, despertou o interesse de diversos profissionais da área (ZANDONINI, 1994). 
Shams e Saadeghvaziri (1997) afirmaram que a popularização dos pilares mistos preenchidos resulta das características como o acréscimo de rigidez da estrutura, de suas propriedades resistentes como resistência mecânica, capacidade de absorver energia e ductilidade, que são adequadas a locais sujeitos à ocorrência de abalos sísmicos.

De uma forma geral, a utilização dos pilares mistos preenchidos é uma boa alternativa para estruturas de grande porte, edifícios altos e reservatórios; a capacidade de dissipação de energia o torna adequado também para construções sujeitas aos abalos sísmicos e a impactos de tráfego, como os viadutos (SHANMUGAN; LAKSHMI, 2001).

De forma simplificada, o tubo de aço é o responsável por resistir às ações provenientes da fase construtiva e do peso próprio da estrutura, pois nesta etapa, o tubo ainda não foi preenchido com concreto. Após o preenchimento e o endurecimento do concreto, este passa a trabalhar em conjunto com o tubo de aço resiste às ações de serviço atuantes na estrutura.

Em países como o Japão e a Austrália, o pilar misto preenchido tornou-se uma prática cada vez mais popular para a construção de edifícios altos. O principal desafio nestes países é tornar o sistema competitivo em relação às estruturas de concreto armado e estruturas metálicas, viabilizando seu uso em estruturas convencionais. O crescimento e a popularização do sistema devem-se, principalmente, à velocidade de execução e à minimização do custo referente à não utilização de fôrmas, já que nestes países, o custo local da madeira atinge valores bastantes elevados (UY, 1998).

Uy (1998) ressalta que a evolução dos métodos de dimensionamento, bem como a aferição de parâmetros como ductilidade, resistência e estabilidade, podem aumentar a competitividade do sistema.

Do ponto de vista arquitetônico, uma vantagem do uso dos pilares mistos preenchidos está no fato de que a redução da seção transversal dos pilares possibilita um melhor 
aproveitamento da área construída, como ocorreu na construção do edifício Baiyooke II Tower, em Bangkok (KILPATRICK; RANGAN, 1999).

\subsubsection{Comportamento Estrutural}

Sucintamente a capacidade resistente da seção de um pilar misto submetido à compressão centrada pode ser dada pela soma da resistência dos seus materiais constituintes (concreto, aço e armaduras), como dado pela Equação 2.1.

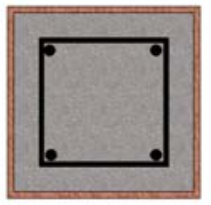

$N_{R, p l d}$

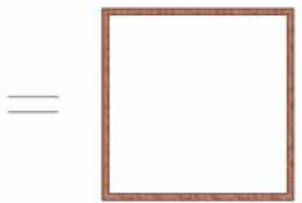

$=A_{a} f_{y d}$

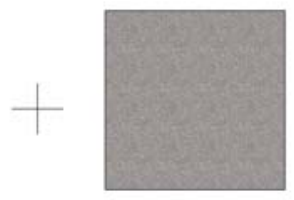

$+A_{c} f_{c d}$

$N_{R, p l d}$ : Resistência à plastificação total da seção

$A_{c}: \quad$ Área de concreto

$A_{s}: \quad$ Área da armadura imersa no concreto

$A_{a}: \quad$ Área de aço

$f_{c d}$ : Resistência de calculo à compressão do concreto

$f_{y s d}$ : Resistência de calculo ao escoamento da armadura

$f_{y d}$ : Resistência de calculo ao escoamento do aço

Na análise, pode ser levado em consideração o aumento da resistência do concreto devido ao efeito do confinamento, principalmente para pilares curtos e de seção circular, bem como os efeitos da flambagem do perfil tubular. Outros efeitos podem ser considerados para representar, de forma mais real, o comportamento estrutural do pilar misto preenchido, como a aderência aço-concreto, a retração e a fluência do concreto, flambagem local e as tensões residuais do perfil de aço.

Os modos de ruína possíveis no pilar misto preenchido solicitado por força normal centrada são: 
- Esmagamento do concreto

- Flambagem global do tubo de aço

- Escoamento do tubo de aço

O modo de ruína dos pilares preenchidos é predominantemente governada pela esbeltez do pilar. Para pilares curtos e medianamente esbeltos, a ruína pode ocorrer por escoamento do tubo de aço ou por esmagamento do concreto. Já para pilares esbeltos, a ruína ocorre geralmente por flambagem do tubo de aço.

Para Shams e Saadeghvaziri (1997), experimentalmente são observados apenas dois tipos de ruína nos pilares preenchidos: flambagem do tubo de aço (pilares esbeltos) e esmagamento do concreto (pilares curtos). Os fatores que afetam a resistência e a ductilidade do pilar preenchido são: a esbeltez, a espessura do tubo e a resistência dos componentes.

Huang et al. (2002) concluíram, a partir de estudos experimentais, que a esbeltez e a espessura do tubo de aço são os principais fatores que determinam tanto o modo de ruína como a capacidade resistente do pilar misto preenchido.

O processo construtivo do pilar misto preenchido requer que o tubo de aço tenha capacidade de resistir ao seu peso próprio e às ações provenientes da construção (peso próprio da laje, vigas e etc.), pois nesta etapa, o tubo ainda não foi preenchido pelo concreto. Desta forma, Han e Yao (2003) analisaram experimentalmente o efeito do pré-carregamento no tubo de aço antes do preenchimento com concreto. Os resultados indicaram que o précarregamento no tubo de aço causa um acréscimo de deformação e uma perda de resistência de até $15 \%$ para alguns casos.

Neste estágio, quando ocorre a concretagem do núcleo, o tubo de aço deve ser capaz de resistir à pressão lateral aplicada internamente pelo concreto em estado fresco. 
Ao longo da vida útil, as ações de serviço são resistidas pelo conjunto aço-concreto. Outros tipos de ações, como aquelas devidas aos efeitos de longa duração, como a deformação lenta do concreto (fluência) e a retração podem atuar no pilar misto preenchido. A deformação lenta do concreto causa redução das tensões no concreto e, consequentemente, acréscimo de tensões no tubo de aço.

A forma da seção transversal também influi no comportamento dos pilares mistos preenchidos, pois pilares de seção circular e retangular apresentam comportamentos distintos, principalmente quanto à ductilidade. Nos pilares mistos de seção circular o efeito do confinamento é mais pronunciado resultando em comportamento dúctil em todos os estágios de carregamento. Por outro lado os pilares de seção quadrada apresentam perda considerável de ductilidade após atingir a carga de ruptura e a forma da seção diminui a contribuição do confinamento. Como resultado, o desempenho da aderência entre o aço e o concreto na interface é inferior (FUJIMOTO et al., 2004).

O comportamento dúctil dos pilares mistos preenchidos é uma característica importante. Comparado aos elementos de aço e de concreto armado, o pilar preenchido apresenta melhor desempenho em relação à ductilidade.

O grau de ductilidade é afetado pela resistência dos materiais, embora Cederwall, Engstrom e Gravers (1990) tenham confirmado experimentalmente que apenas nos pilares esbeltos o concreto contribui para a ductilidade, e que o aço contribui de forma mais significativa para o aumento da ductilidade. O uso das armaduras de aço no núcleo de concreto traz efeitos benéficos para a ductilidade do pilar misto.

Uy (1998) realizou um estudo experimental com o intuito de avaliar o parâmetro de ductilidade em pilares curtos, variando parâmetros como a resistência do concreto, resistência do aço e o tipo de carregamento aplicado (compressão simples e flexo-compressão). Os resultados indicaram que o aumento da resistência dos materiais que compõem o pilar misto 
causa perda considerável de ductilidade, principalmente quando este pilar é solicitado por flexo-compressão.

Outro estudo experimental para avaliar a ductilidade de pilares preenchidos compostos por materiais de alta resistência foi realizado por Liu, Gho e Yuan (2003). Neste estudo, foi concluído que apesar do uso dos materiais de alta resistência ocasionar perda de ductilidade, ainda assim os pilares apresentam comportamento satisfatório quanto à ductilidade.

Fujimoto et al. (2004) afirmam que o concreto de alta resistência nos pilares mistos preenchidos leva à perda de ductilidade, mas a combinação com o aço de alta resistência pode garantir ductilidade adequada, principalmente em seções compactas.

\subsubsection{O concreto no pilar misto preenchido}

Nos pilares mistos preenchidos, o concreto tem o papel de adicionar rigidez e contribuir para a capacidade resistente do pilar quanto à instabilidade local do perfil tubular. A rigidez do concreto contribui para minimizar os problemas de flambagem local do perfil tubular. Outras características do material são importantes para o comportamento estrutural do pilar misto, dentre elas se destaca o aumento da resistência do concreto devido ao confinamento. Fatores como retração e fluência também influem no comportamento do pilar, apesar de alguns autores afirmarem que a influência de tais propriedades é demasiadamente pequena. O uso do concreto de alta resistência também é um assunto abordado com freqüência pelos pesquisadores, principalmente quando este é aliado ao aço de alta resistência.

O ganho de resistência do concreto pelo seu envolvimento com o tubo de aço, devido ao efeito de confinamento, é um dos aspectos mais abordados por pesquisadores da área. Diversos são os parâmetros que interferem no grau de confinamento dos pilares mistos, como a resistência do concreto, a espessura e o comprimento do tubo e o tipo de carregamento. As normas que abordam o dimensionamento do pilar misto, como o EUROCODE 4 (2004) o PR 
- NBR 8800 (2007) e o ANSI/AISC (2006) consideram o aumento da resistência do concreto pelo confinamento.

Além dos modelos de confinamento encontrados em algumas normas, modelos matemáticos podem ser encontrados na literatura como em Sakino e Sun (1994) e Sakino et al (1998)

O efeito do confinamento só é mais expressivo em seções circulares, podendo ser desprezado em seções quadradas e retangulares, ocorrendo apenas nos cantos da seção. Para solicitações de flexo-compressão, à medida que há um acréscimo de momento aplicado o efeito do confinamento tende a ser menor (SHANMUGAM; LAKSHMI, 2001).

Liu, Gho e Yuan (2003) realizaram um estudo experimental com pilares mistos solicitados por carregamento axial, com o intuito de avaliar o confinamento do concreto. Além das propriedades mecânicas do concreto, o efeito de confinamento depende diretamente da esbeltez do pilar misto e da espessura do tubo de aço, pois para pilares com tubos de pequena espessura a ruína pode ocorrer por flambagem local do tubo de aço, com carregamento inferior ao necessário para mobilizar o confinamento do concreto. Os autores afirmam que os resultados indicam discrepância entre resultados experimentais e as formulações presentes no AISC/ANSI 360 (em torno de 16\%), indicando que a formulação da norma é conservadora em relação a consideração do confinamento..

O efeito de confinamento na flexo-compressão tende a ser menor, ou até insignificante, quando o pilar é solicitado por flexo-compressão. Fujimoto et al. (2004) estudaram o comportamento de pilares mistos preenchidos com a aplicação de carga axial excêntrica, sendo observado que o efeito de confinamento não deve ser considerado para este tipo de solicitação. 
Para descrever o confinamento do concreto no pilar misto preenchido solicitado por carregamento axial, pode-se dividir o comportamento do concreto em três etapas distintas. Na primeira etapa, ao início do carregamento do pilar misto preenchido, o concreto possui um coeficiente de Poisson menor que o do aço (0,2 para o concreto e 0,3 para o aço). Desta forma, a expansão lateral do concreto é muito pequena. Quando se inicia a fissuração do concreto (segunda etapa), o concreto ultrapassa o seu limite elástico e seu coeficiente de Poisson atinge um valor em torno de 0,5, ocasionando expansão lateral do concreto e, consequentemente, o surgimento de uma pressão interna aplicada pelo concreto no tubo de aço. Neste instante, o núcleo de concreto assume um estado tri-axial de tensões e o tubo de aço, um estado biaxial de tensões aumentando, desta forma, a resistência total do conjunto, até a ruína (terceira etapa) (SHAMS; SAADEGHVAZIRI, 1997).

Sakino et al. (2004) analisaram o efeito de confinamento em pilares curtos mediante ensaios experimentais e expressões analíticas. Foram ensaiados 114 pilares mistos preenchidos (seção circular e quadrada), com variação da resistência dos dois materiais, espessura do tubo e dimensões da seção transversal. Foi comprovado que a carga última dos pilares mistos preenchidos de seção circular é sempre superior às expressões analíticas que não consideram o confinamento, e o mesmo não ocorrendo para seções quadradas. Esses resultados evidenciam o aumento da capacidade resistente do pilar misto preenchido de seção circular pelo efeito de confinamento do concreto. Alguns resultados obtidos pelos autores estão expostos na Tabela 2-1, evidenciando o efeito benéfico do confinamento em pilares curtos de seção circular.

Pelos resultados obtidos por Sakino et al. (2004) é possível observar o acréscimo de resistência devido ao confinamento do concreto na maior parte dos resultados. Para relações $\mathrm{D} / \mathrm{t}$ altas o confinamento tende a ser menor e o mesmo ocorre para relação fyk/fck baixas. O aumento da resistência devido ao confinamento ocorre apenas para pilares de seção circular, 
pois no mesmo estudo ensaios de pilares de seção quadrada e retangular não apresentaram resultados positivos.

Tabela 2-1 - Resultados experimentais obtidos por Sakino et al. 2004.

\begin{tabular}{cccccc}
\hline $\begin{array}{c}f y k \\
(\mathrm{MPa})\end{array}$ & $\begin{array}{c}\mathrm{fck} \\
(\mathrm{MPa})\end{array}$ & $\mathrm{fyk} / \mathrm{fck}$ & $\mathrm{D} / \mathrm{t}$ & $\begin{array}{c}\text { Carga de ruptura } \\
\text { experimental }(\mathrm{kN})\end{array}$ & $\begin{array}{c}\text { Relação experimental e analítico (sem } \\
\text { efeito do confinamento) }\end{array}$ \\
\hline 308 & 25,4 & 12,12 & 50,4 & 941 & 1,16 \\
\hline 308 & 40,5 & 7,6 & 50,4 & 1064 & 1,02 \\
\hline 576 & 40,5 & 14,2 & 26,8 & 1657 & 1,22 \\
\hline 507 & 40,5 & 12,51 & 52,5 & 3583 & 1,12 \\
\hline 525 & 40,5 & 12,96 & 79,4 & 5,633 & 1,17 \\
\hline 853 & 40,5 & 21,06 & 16,7 & 2446 & 1,19 \\
\hline 853 & 77 & 11,07 & 16,7 & 2713 & 1,01 \\
\hline 279 & 40,5 & 10,98 & 100 & 3277 & 0,99 \\
\hline 279 & 25,4 & 10,94 & 152 & 5540 & \\
\hline
\end{tabular}

A retração e a fluência são temas bastante abordados nas estruturas de concreto armado, pois estas propriedades têm a devida importância no comportamento do concreto ao longo da vida útil. Para os pilares mistos os códigos normativos incluem a consideração destes fenômenos de forma simplificada, por meio da penalização da rigidez do concreto.

Segundo Bradford e Gilbert (1990), os efeitos da fluência e da retração do concreto são significativos no comportamento do pilar misto preenchidos, mas podem ser desprezados no dimensionamento.

Nos pilares mistos preenchidos a retração do concreto tende a ser menor do que nos pilares de concreto armado; devido principalmente, às condições favoráveis de umidade dentro do tubo (SHANMUGAN; LAKSHMI, 2001).

Como a retração é menor nos pilares mistos preenchidos, a fissuração do concreto pode ser considerada desprezível, mas a fluência (deformação lenta do concreto) tem efeito significativo, sendo estimada uma perda de cerca de 15\% da resistência total da coluna (SHAMS; SAADEGHVAZIRI, 1997). 
A compactação do concreto também influi no comportamento estrutural dos pilares mistos. Segundo Han e Yao (2003), resultados experimentais indicam que pilares com concreto bem compactado apresentam resultados de resistência e rigidez superiores aos dos pilares com concreto com compactação regular. Nos pilares mistos preenchidos, a compactação do concreto influencia diretamente a aderência aço-concreto, possibilitando melhorar a capacidade de transferência de tensões entre os dois materiais.

O uso de concreto de alta resistência nos pilares mistos preenchidos é uma prática comum em alguns países, como a Austrália e o Japão, para a construção de edifícios altos, pois as vantagens proporcionadas pela utilização de tal material conseguem viabilizar o uso do pilar misto preenchido nestes locais. O maior benefício da utilização do concreto de alta resistência está no fato de permitir que a seção de concreto resista à maior parte da solicitação axial, permitindo que os esforços provenientes do momento fletor sejam resistidos em grande parte pelo tubo de aço (UY, 1998 e 2003).

Outro benefício da utilização do concreto de alta resistência em pilares mistos é o aumento do confinamento no concreto e consequentemente a capacidade de carga do pilar misto (em torno de 30\%) (CEDERWAAL; ENGSTRON; GRAVERS, 1990). No mesmo trabalho ficou evidenciado experimentalmente que o concreto de alta resistência permite aumentar a capacidade resistente do pilar após o tubo de aço atingir seu patamar de escoamento, pois nesta fase de carregamento o concreto consegue ainda contribuir na capacidade resistente do pilar, isto para carregamento centrado ou com pequena excentricidade.

O concreto de alta resistência também contribui para a capacidade resistente do pilar misto quanto à flambagem em pilares esbeltos, pois sua baixa deformabilidade diminui a capacidade de deformação do pilar misto preenchido (FUJIMOTO et al., 2004). 


\subsubsection{O perfil tubular no pilar misto preenchido}

O perfil tubular de aço do pilar misto preenchido é responsável pela resistência da maior parcela de carga, já que possui patamar de resistência maior que o do concreto e é capaz de resistir às tensões de tração, ao contrário do concreto. O principal aspecto a ser ressaltado a respeito do perfil tubular é a ruína por flambagem local. Para pilares mistos esbeltos, a ruína passa a ser governada pela flambagem do perfil tubular. A flambagem local também é um aspecto importante, mas muitas vezes, negligenciado pelos trabalhos científicos. Os códigos normativos apresentam limites para evitar que a ruína do pilar misto ocorra devido à flambagem local do perfil tubular, limitando a relação largura-espessura do perfil. A ruína por flambagem do tubo de aço é tratada pelos códigos utilizando o mesmo procedimento para perfis metálicos tubulares sem preenchimento do concreto, apenas considerando o aumento da rigidez da seção devido ao concreto. Diversos trabalhos mostram experimentalmente que a força de ruptura do pilar misto por flambagem é muito superior à fornecida por estes códigos. Outro aspecto que merece destaque a respeito do aço no pilar misto é a presença de tensões residuais e o pré-carregamento do tubo, anterior ao preenchimento do concreto.

Para pilares muito esbeltos, a ruína ocorre na maioria das vezes, por flambagem do tubo de aço, apesar do núcleo de concreto contribuir de forma positiva neste tipo de ruína. Uma das formas de melhorar a capacidade resistente do pilar misto preenchido é utilizar enrijecedores no tubo de aço, melhorando o comportamento do pilar misto quanto à flambagem.

Outras alternativas de enrijecer o tubo de aço foram estudas por autores, como Huang et al. (2002), que em estudo experimental, inseriu barras de aço soldadas no perfil atuando como enrijecedores. Os resultados demonstraram que o uso destes enrijecedores diminuiu o efeito da flambagem local do tubo de aço e, quanto menor o espaçamento dos enrijecedores, 
melhor o desempenho do pilar misto preenchido. O mesmo autor ressalta que o uso dos conectores de cisalhamento na seção transversal melhora o comportamento da seção, mas possibilita a ocorrência de problemas de flambagem localizada no tubo de aço devido à concentração de tensões na região dos conectores.

Uy (1998) destaca que o estabelecimento de um método de dimensionamento que considere a flambagem local do tubo de aço e a esbeltez do pilar misto preenchido de forma mais realista é necessário, já que resultados experimentais demonstraram que as formulações normativas apresentam valores conservadores.

Wang (1998), em seu estudo experimental, realizou ensaios em uma série de pilares mistos preenchidos esbeltos. Os resultados experimentais foram comparados aos procedimentos do Eurocode 4 (1992). Os resultados obtidos pelas normas apresentaram valores bastante conservadores. A relação entre os resultados analíticos e experimentais variou entre 0,58 e 0,92 .

Outra característica dos pilares mistos preenchidos esbeltos é que, depois de atingida a sua resistência máxima, apresentam uma menor capacidade residual resistente, quando comparada a pilares curtos, além de apresentarem deslocamentos superiores para a mesma carga aplicada (KILPATRICK; RANGAN, 1999).

O pilar misto preenchido tem por volta de $50 \%$ mais capacidade resistente quanto à flambagem local da seção, quando comparada ao mesmo perfil tubular de aço comum. O principal fator que interfere nesse comportamento é a relação entre a espessura do tubo e a dimensão da seção transversal.

O uso de materiais de alta resistência, concretos com resistência à compressão acima de 50 MPa e aços com resistência ao escoamento acima de $600 \mathrm{MPa}$, nos pilares mistos preenchidos tem sido estudado e utilizado com grande freqüência nos últimos anos, já que as 
vantagens que o sistema possibilita tornam-se mais evidentes quando aliado ao uso destes materiais, como mostrou o estudo experimental de Kilpatrick e Rangan (1999).

\subsection{Ligações viga-pilar misto preenchido}

As ligações viga-pilar são geralmente classificadas de acordo com sua resistência, rigidez e ductilidade. O PR - NBR 8800 (2007) classifica, as ligações de acordo com a rigidez, em: rotuladas, semi-rígidas e rígidas. As ligações rotuladas são comumente chamadas de ligações flexíveis.

Quanto à resistência, as ligações podem ser classificadas em:

- Resistência total: A ligação tem resistência igual ou maior que a dos elementos conectado, por isso, a formação de rótulas plásticas ocorrerá nos elementos e não na ligação.

- Resistência parcial: A resistência da ligação é menor que a dos elementos conectados, desta forma a formação de rótulas plásticas ocorrer inicialmente nas ligações.

- Rotuladas: A ligação só tem capacidade de transmitir esforços normais e de cisalhamento.

O estudo das ligações viga-pilar misto é muito recente, causando assim o surgimento de um número muito variado de ligações. Muitos detalhes de ligação são adaptados das ligações de aço em perfis tubulares, às vezes com a adição de algum elemento ancorado no núcleo de concreto. Além das ligações mistas (onde a laje da viga mista contribui no comportamento da ligação), os autores subdividem os tipos de ligações viga-pilar misto preenchido em duas grandes categorias: as ligações externas são aquelas onde a ligação é feita 
diretamente no tubo de aço e as ligações internas são aquelas onde parte dos esforços é transferida também ao núcleo de concreto através da ancoragem de elementos no mesmo. O critério para a escolha da ligação depende do tipo de aplicação. Em aplicações convencionais para estruturas com carregamento estático, o critério é baseado na rigidez e resistência; em estruturas sujeitas a abalos sísmicos, o critério é baseado na dissipação de energia e na estabilidade (BEUTEL; THAMBIRATNAM; PERERA, 2000).

De Nardin (2006) afirma que grande parte dos trabalhos internacionais a respeito de ligações viga-pilar misto preenchido são realizados em locais onde a ocorrência de abalos sísmicos possui uma freqüência significativa. Desta forma, o ideal é tentar adaptar estas ligações para a realidade brasileira.

O principal problema nas ligações viga-pilar misto preenchido diz respeito à transferência de tensões entre os dois materiais na superfície de contato, que ocorre via mecanismos de transferência de forças (adesão química, aderência mecânica e atrito). Nesta região, é necessário o equilíbrio entre as forças atuantes e para que isto ocorra, o deslizamento relativo entre os dois materiais não pode assumir um valor significativo. Se a tensão de cisalhamento entre o tubo de aço e o núcleo de concreto exceder a resistência de aderência entre os dois materiais, ocorrerá deslizamento relativo que causará mudanças permanentes na interface. (ROEDER; MACRAE; WATERS, 2000).

\subsubsection{Ligações externas}

As ligações externas são caracterizadas pelo baixo custo e pela simplicidade de execução, podendo ser enrijecidas ou não enrijecidas. France, Davison e Kirby (1998) apresentam alguns tipos de ligação viga-pilar misto preenchido usuais. Estas ligações são realizadas por meio da soldagem de perfis no tubo de aço; estes perfis são parafusados na alma ou mesa da viga de aço. Os perfis mais utilizados são as cantoneiras e os perfis de seção 
“T” (Figura 2-1). Um tipo mais simples de ligação é realizado pela soldagem de uma chapa diretamente no perfil tubular (Figura 2-2).

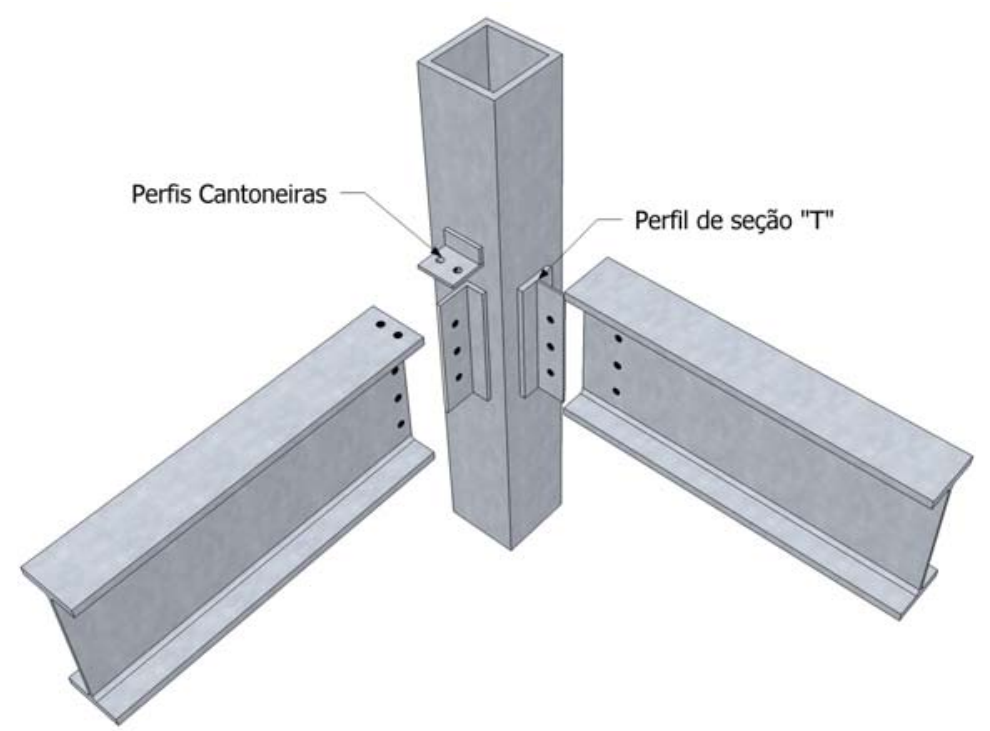

Figura 2-1 - Ligação viga-pilar misto - Externa com soldagem de perfis de aço.

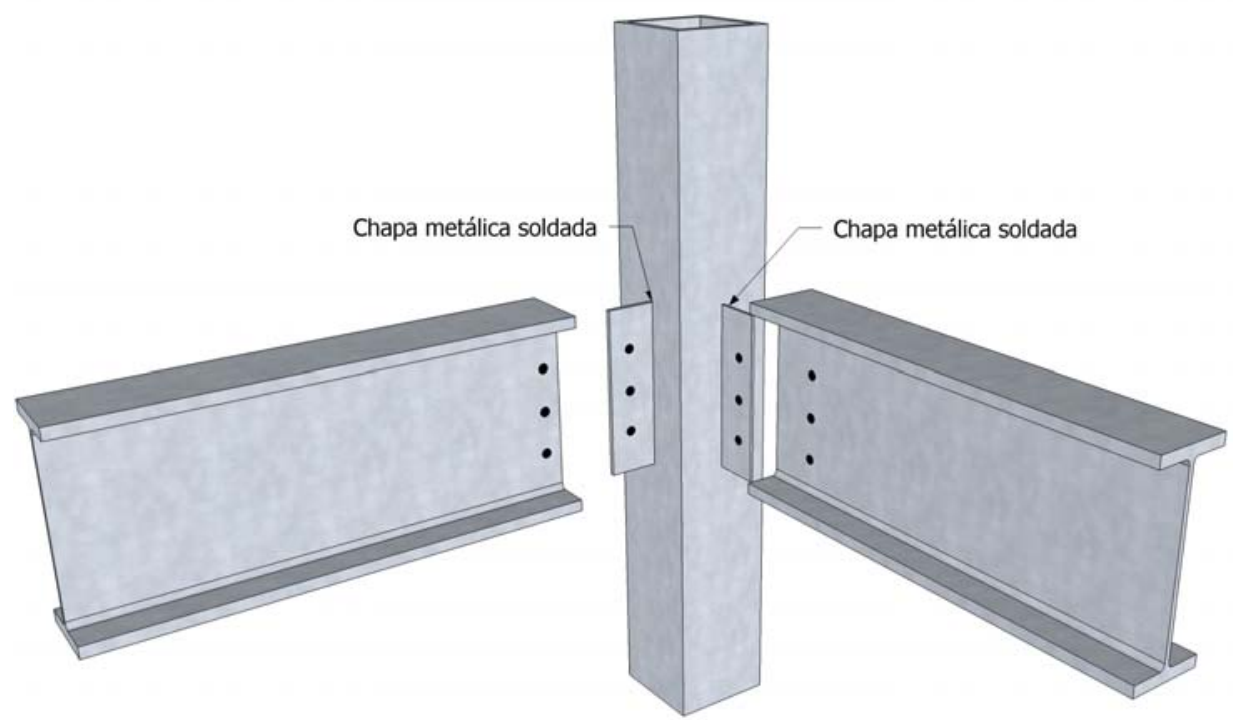

Figura 2-2 - Ligação viga-pilar misto - Externa com soldagem de chapa de aço.

Um dos problemas que podem ocorrer nas ligações soldadas é sua baixa rigidez e a ocorrência de concentração de tensões no tubo de aço (podendo levar à ruptura do tubo de aço na região da ligação). Como a ligação é feita apenas via tubo de aço, deve ser garantida a transferência de tensões entre aço e concreto, evitando a ruína causada por efeitos localizados no tubo de aço. A deformação localizada na parede do tubo pode ocasionar problemas 
internos no núcleo de concreto, como a concentração de tensões de compressão na região inferior e o desprendimento do concreto em relação ao perfil, na região superior. Outra forma de ruína possível é o escoamento nas mesas da viga de aço. O desprendimento do concreto leva à perda do efeito de confinamento do concreto na região da ligação.

France, Davison e Kirby (1998) ressaltam que a utilização de parafusos na ligação em substituição à solda possibilita melhoraria no desempenho, mas, em contrapartida, torna necessário o aumento da espessura do tubo e dificulta a execução da ligação. Sendo assim, os autores propõem a utilização de um processo térmico para a perfuração do tubo de aço, o “flowdrill process”, que possibilita o uso de parafusos, sem a necessidade de aumentar a espessura do tubo de aço, mantendo a facilidade de execução. A Figura 2-3 mostra a técnica sugerida e as ligações estudadas. Os resultados obtidos mostraram que a rigidez e a resistência da ligação dependem diretamente das dimensões da chapa de extremidade utilizada.

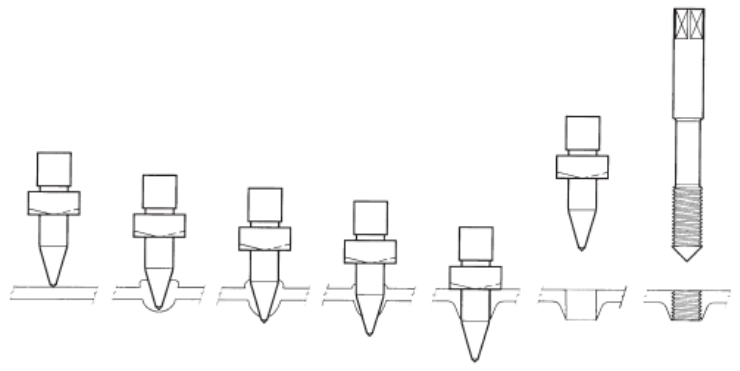

a) "Flowdrill process" para ligação direta das chapas de aço
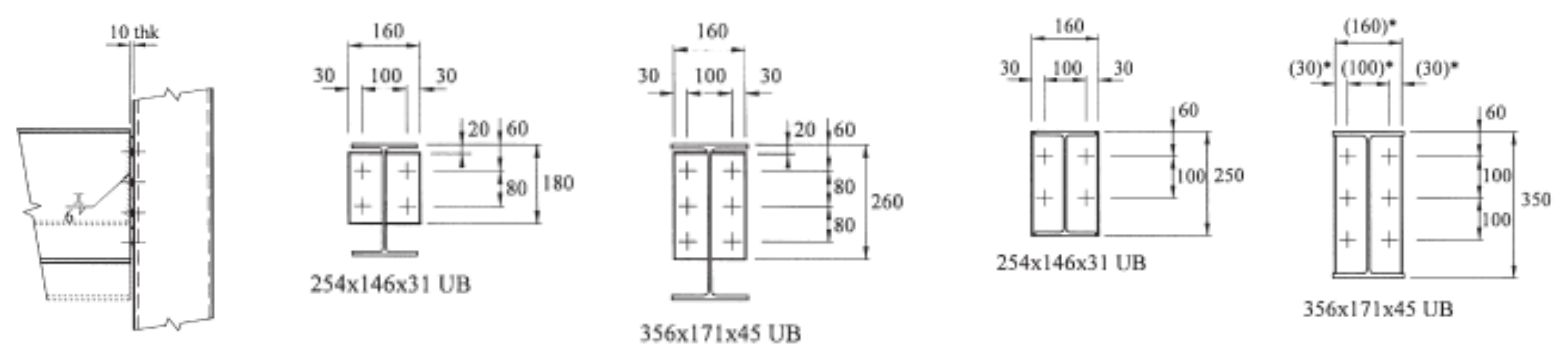

b) Ligações estudadas

Figura 2-3 - Ligação estudada por France, Davison e Kirby (1998)

Para melhorar o desempenho das ligações externas podem ser utilizadas diversas formas de enrijecimento da região de ligação. Tal enrijecimento diminui a ocorrência da 
flambagem do tubo de aço e de esmagamento do concreto, sendo que a ruína é localizada diretamente na ligação.

O uso de diafragmas para enrijecimento da ligação é uma alternativa apresentada por diversos autores (Figura 2-4), podendo ser utilizados apenas enrijecedores externos ou internos, passando através do núcleo de concreto. Nishiyama et. al (2004) realizaram ensaios experimentais em ligações viga-pilar misto preenchido utilizando diafragmas e verificaram que as ligações enrijecidas apresentam ganho de rigidez em torno de 25\%. Uma das vantagens da utilização do diafragma que atravessa internamente o pilar é a possibilidade do aumento da resistência da ligação devido ao aumento do confinamento do concreto.

Alostaz e Schneider (1996) analisaram numericamente o comportamento de ligações viga-pilar misto preenchido de seção circular, analisando a inclusão do diafragma na ligação externa. Os resultados indicaram que tal inclusão melhora o desempenho da ligação em relação à resistência e à rigidez, reduzindo o diâmetro do tubo de aço do pilar misto.
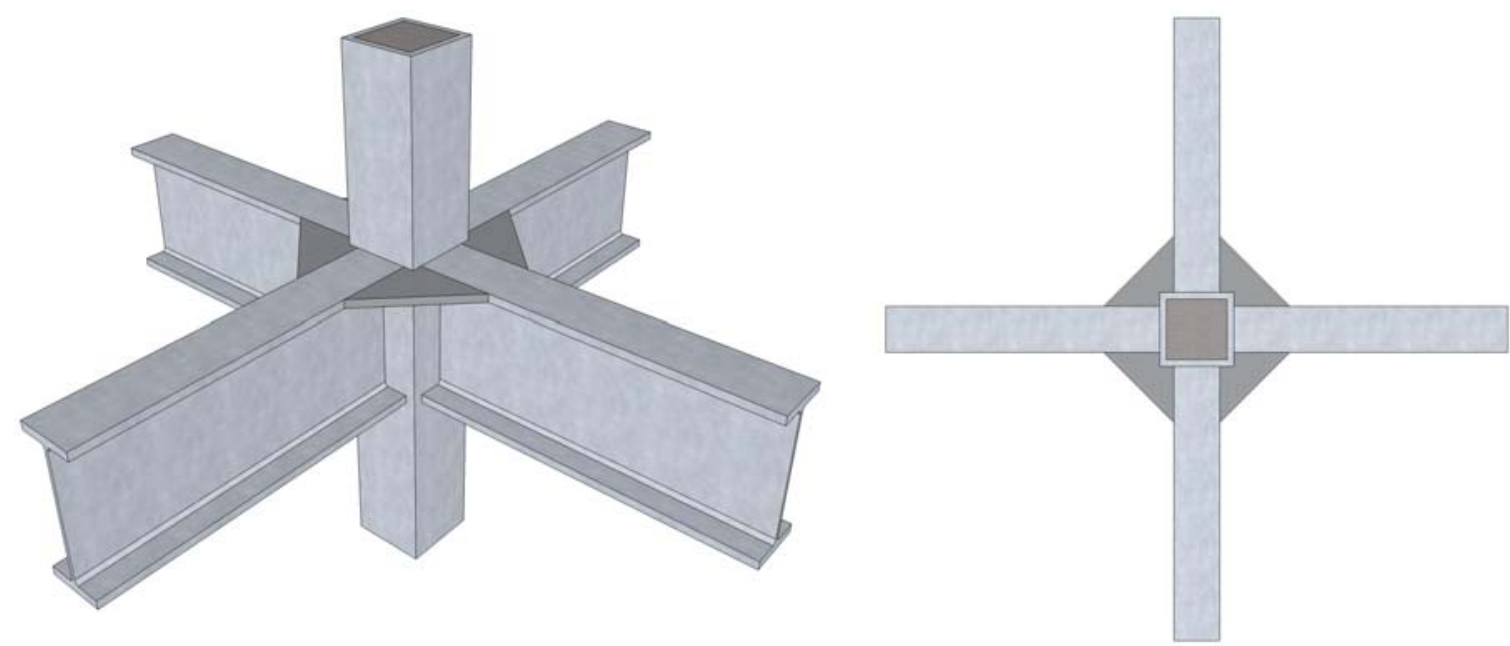

Figura 2-4 - Ligação externa com o uso de diafragmas externos.

Para promover a transferência de esforços entre o aço e concreto, podem ser utilizados conectores de cisalhamento ou outro mecanismo de transferência internamente no tubo de aço, como foi realizado por Ricles, Peng \& Lu (2004). Neste estudo, foram analisados vários 
detalhes de ligação externa com o uso de conectores de cisalhamento internamente no pilar. Na Figura 2-5 estão expostas algumas das ligações estudadas.

O uso dos conectores de cisalhamento internamente não resultou em influência significativa sobre o comportamento destas ligações. Os resultados indicaram que o uso de perfis de aço parafusados na mesa e ligados ao pilar por meio de parafusos passantes apresentou o melhor desempenho entre as ligações. Foi concluído também que as ligações soldadas resultam em concentração de tensões nos pilares, prejudicando seu desempenho. O uso dos diafragmas depende diretamente da viga de aço, pois se esta não possuir dimensões adequadas, o diafragma não será eficiente.

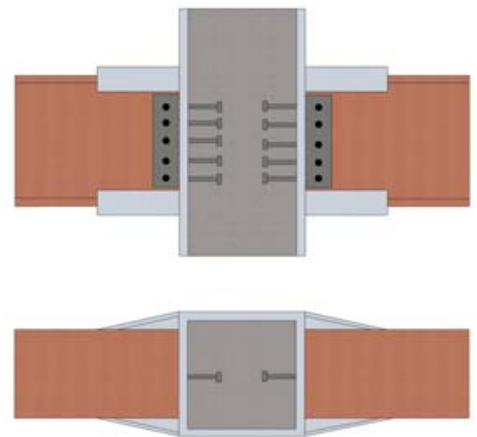

a) Ligação com enrijecedores externos

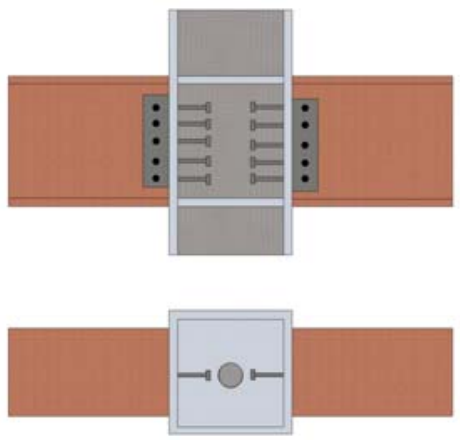

b) Ligação com diafragmas internos

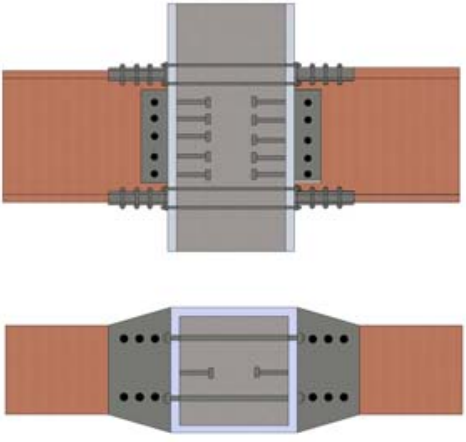

c) Ligação com parafusos passantes e chapas parafusadas nas mesas da viga de aço

Figura 2-5 - Ligações externas, com o uso de conectores de cisalhamento internos, Ricles, Peng e Lu (2004)

\subsubsection{Ligações internas}

As ligações internas são projetadas para transmitir diretamente as forças das mesas da viga para o núcleo de concreto. Essas ligações podem ser realizadas via ancoragem de elementos como chapas, parafusos passantes, conectores de cisalhamento e armaduras de aço no núcleo de concreto. 
Este tipo de ligação geralmente apresenta desempenho superior quando comparadas com as ligações externas. Em contrapartida apresentam desvantagens em relação aos custos e dificuldades de execução. Em algumas ligações internas existe a possibilidade da ocorrência de problemas na concretagem, como o surgimento de nichos ou aumento de vazios no concreto.

A alta capacidade de dissipação de energia, propriedade adequada para locais sujeitos a abalos sísmicos, é uma das características apresentada pelas ligações internas. Por isso, boa parte das referências bibliográficas a respeito destas ligações envolve o comportamento perante cargas provenientes de abalos sísmicos e, geralmente pilares de seção circular.

Um tipo de ligação viga-pilar misto preenchido estudada por Azizinamini, Shekar e Saadeghvaziri (1995) e por Alostaz e Schneider (1996), no qual a ligação é realizada pela ancoragem da viga diretamente no núcleo de concreto é mostrado na Figura 2-6.

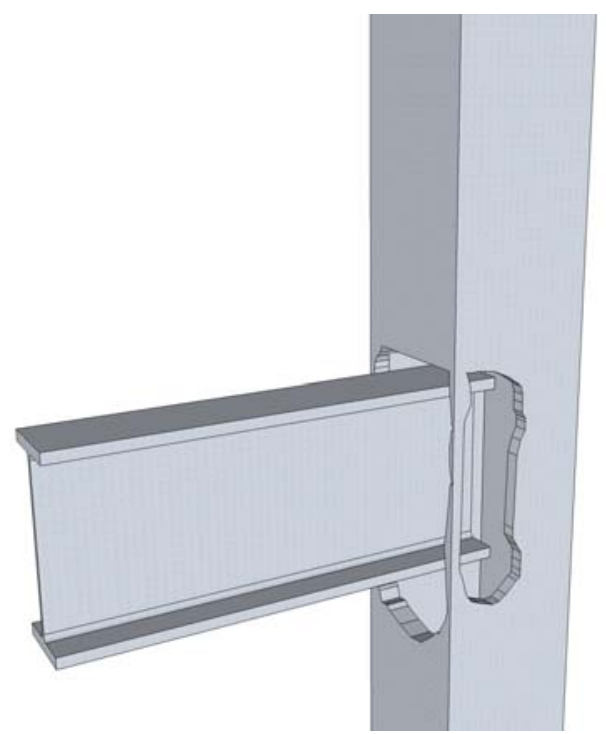

Figura 2-6 - Ligação interna com a ancoragem direta da viga de aço (AZIZINAMINI; SHEKAR ; SAADEGHVAZIRI, 1995).

As mesas da viga ancoradas no concreto atuam como enrijecedores para o pilar, pois tais mesas acabam criando uma biela de compressão que atua em conjunto com a alma da viga. As mesas também ajudam a diminuir as tensões presentes no tubo de aço. Os resultados 
experimentais obtidos pelos autores mostraram que a ligação apresenta comportamento rígido e desempenho superior, quando comparada a outras ligações. A capacidade de dissipação de energia desta ligação é ideal para locais com a probabilidade de ocorrência de sismos. A desvantagem desta ligação é que só pode ser utilizada com perfis tubulares de grande espessura e possui alto custo de execução devido à necessidade do corte do perfil tubular para ancoragem da viga.

A ancoragem de uma chapa “Gusset” no concreto é outro detalhe de ligação proposta por Roeder, Macrae e Waters, (1994) (Figura 2-7). Adicionalmente podem ser utilizados conectores tipo pino com cabeça na chapa. O estudo indicou que a penetração da chapa modifica a distribuição de forças e momentos entre os dois materiais. A utilização de conectores de cisalhamento na chapa "Gusset” não aparentou ser eficiente para a transferência de tensões, pois os conectores são flexíveis e o desenvolvimento da resistência ao cisalhamento destes ocorre apenas quando estes sofrem deformação significativa. O uso de algum mecanismo com alta rigidez na chapa pode melhorar o desempenho deste detalhe de ligação.

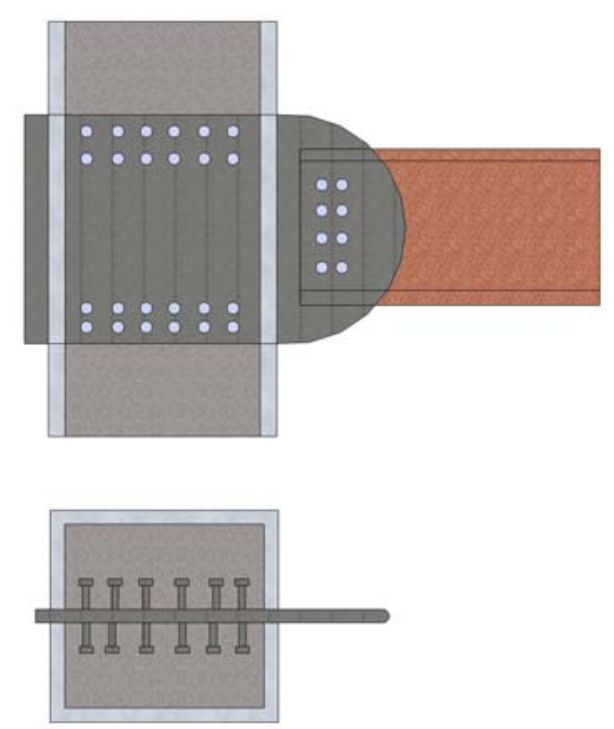

a) Ancoragem de chapa "gusset" - Roeder, Macrae e Waters, (1994)

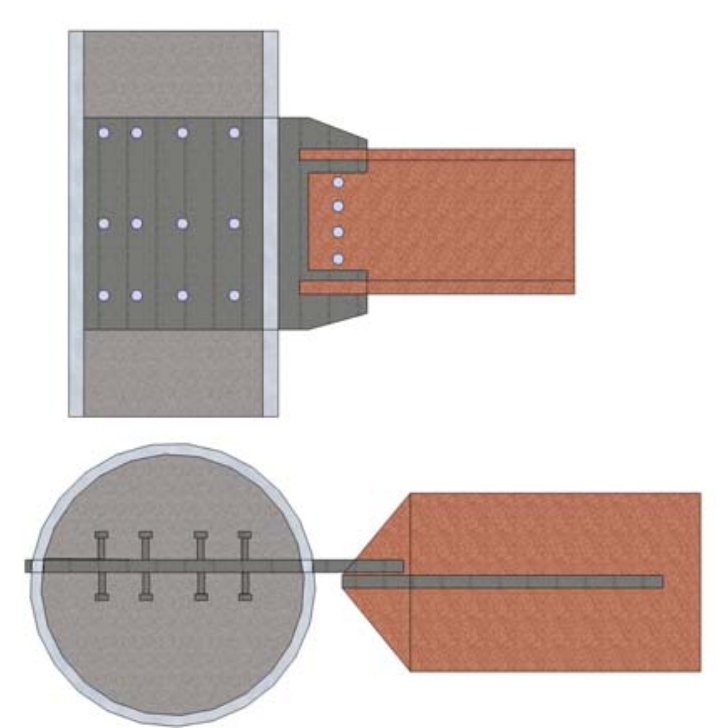

b) Ancoragem de chapa metálica - Alostaz e Schneider, (1996)

Figura 2-7 - Ligação interna com o uso de chapa "gusset". 
Uma variação de detalhe de ligação foi estudada por Alostaz e Schneider (1996), diferenciada apenas pelo tipo de chapa ancorada no núcleo de concreto (Figura 2-7b). Da mesma forma, foram utilizados conectores de cisalhamento tipo "pino com cabeça” na chapa de aço. A ligação se comportou como uma ligação flexível. Embora apresente custo relativamente alto, apresentou bom desempenho para uma ligação flexível. Os conectores promoveram o aumento da rigidez quando comparada com a mesma ligação sem conectores, mas seu uso aumenta o custo da ligação sem trazer grandes benefícios.

Gardner e Goldsworthy propõem uma ligação externa com ancoragem interna dos parafusos no núcleo de concreto (Figura 2-8). Resultados demonstraram que a ancoragem dos parafusos aumenta a rigidez e a capacidade resistente da ligação, à medida em que é aumentado o comprimento de ancoragem dos parafusos.
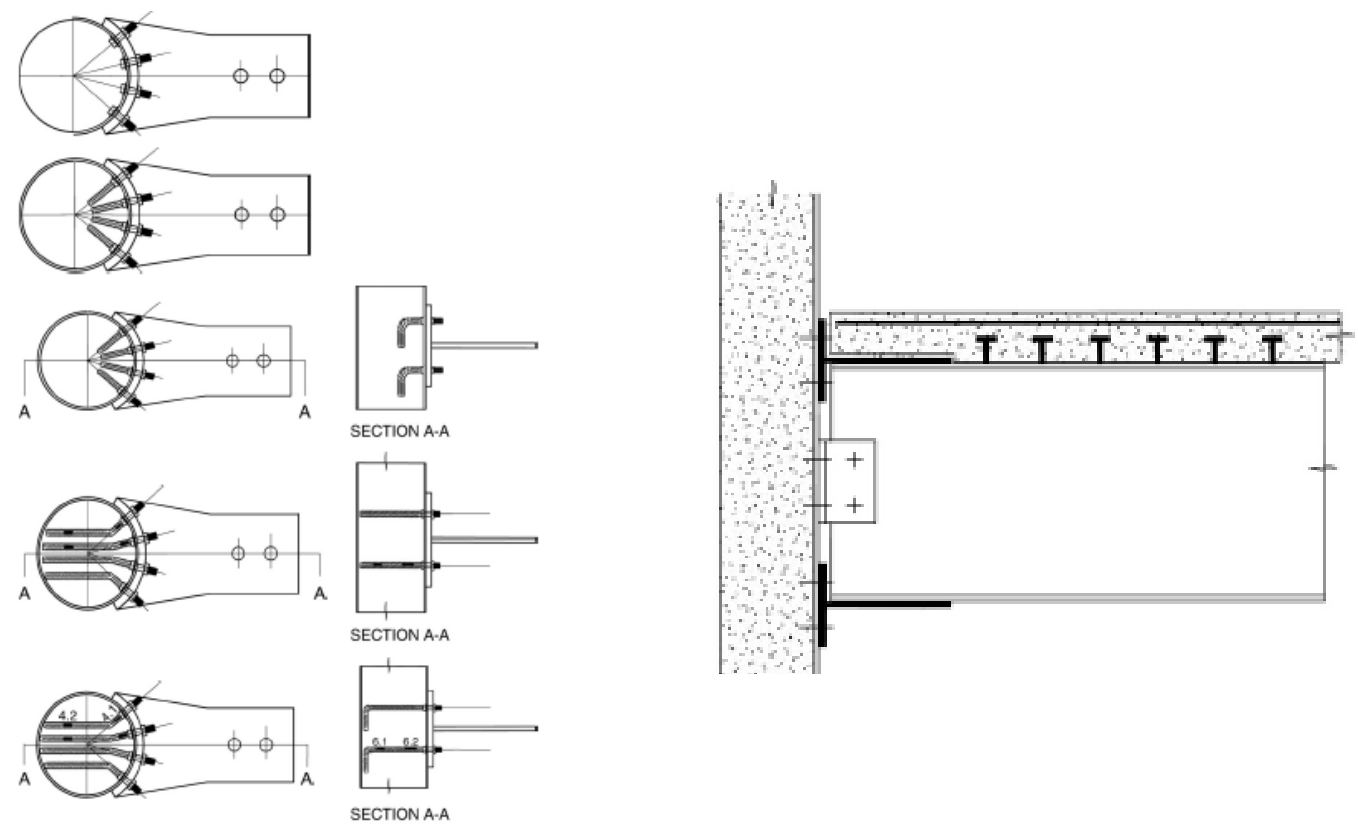

Figura 2-8 - Ligação interna com ancoragem de parafusos no concreto.

A ancoragem de armaduras no núcleo de concreto do pilar misto é mais uma forma de promover o enrijecimento das ligações viga-pilar misto estudada por diversos autores como Beutel, Thambiratnam e Perera (2001). Em seu estudo, foi analisado experimentalmente o comportamento de uma ligação viga-pilar misto de seção circular com a ancoragem de barras 
de aço no núcleo de concreto (Figura 2-9). As armaduras ancoradas no núcleo de concreto aumentam o custo da ligação, mas melhoram consideravelmente seu desempenho quanto à dissipação de energia, resistência e rigidez. Neste caso, a ligação se comporta como uma ligação rígida e a utilização das armaduras reduz a concentração de tensões nas mesas da viga aço, levando esses esforços para o núcleo de concreto. Um aspecto importante neste tipo de ligação é a ancoragem adequada das armaduras (ganchos e comprimento de ancoragem). Segundo Alostaz e Schneider (1996), a ancoragem das armaduras via ganchos com uma inclinação de $90^{\circ}$ resultam em melhor desempenho e eficiência quando comparada com o mesmo tipo de ligação com diferentes configurações de ancoragem.
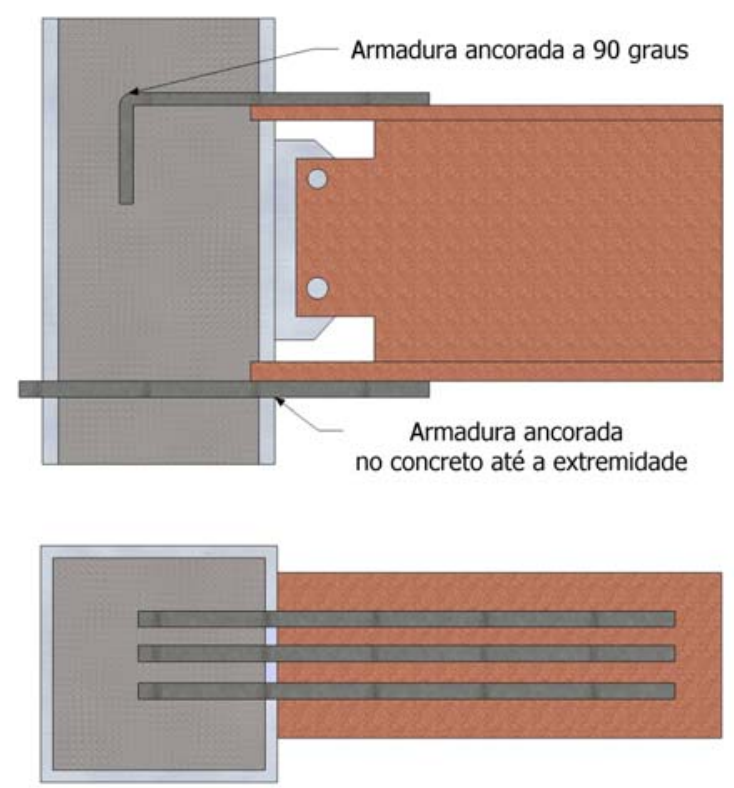

Figura 2-9- Ligação interna com ancoragem de armaduras de aço (Alostaz e Schneider, 1996 e Beutel, Thambiratnam e Perera, 2001).

A ancoragem das armaduras no pilar misto também foi estudada por Ashadi e Bouwkamp (1995), mas na ligação viga-pilar, a viga era de concreto armado e onde as armaduras de flexão da viga eram ancoradas no núcleo de concreto do pilar misto (Figura 2-10). A proposta do trabalho foi de avaliar a resistência deste tipo de ligação perante ações provenientes de abalos sísmicos. As amostras variavam pelo tipo de ancoragem e pelo arranjo de armaduras. Foi avaliada a aderência entre as armaduras e o concreto para caracterizar o 
comportamento da ancoragem. Os resultados indicaram que a ancoragem com ganchos e a soldada no fim do pilar fazendo que a ruína ocorra na armadura e não na aderência, concluindo que este tipo de ancoragem é a ideal. Da mesma forma, as ligações com estas ancoragens tiveram o melhor desempenho. Os autores concluíram que as ligações tiveram bom desempenho, mas ocorreram problemas de cisalhamento da região de ligação, quanto à dissipação de energia, desta forma deve-se prever uma armadura de cisalhamento adicional nas extremidades da viga.

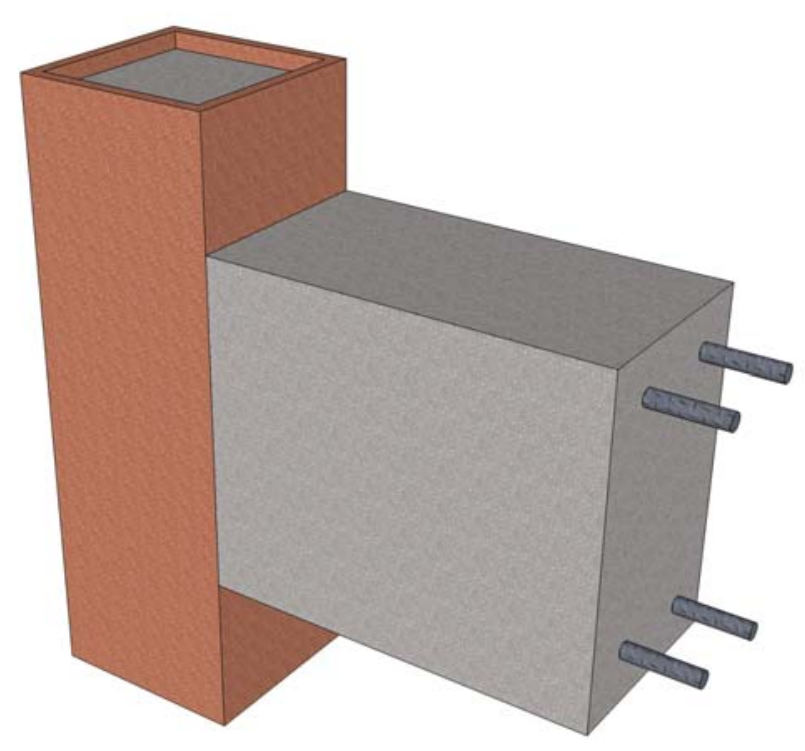

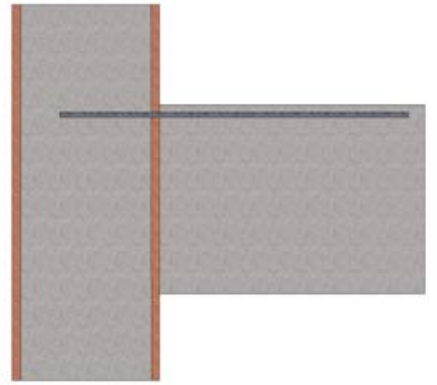

Ancoragem normal

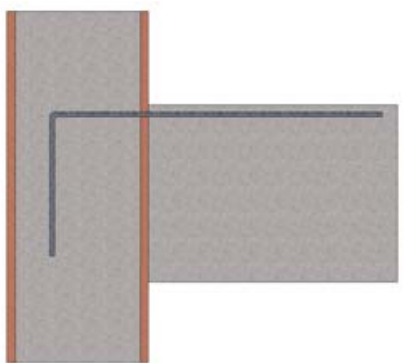

Ancoragem com gancho a 90 graus

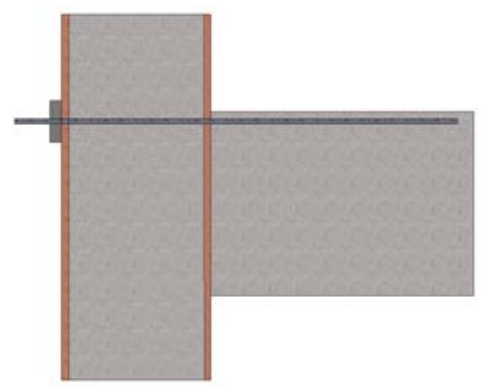

Ancoragem soldada até extremidade do tubo metalico

Figura 2-10 - Ligação interna com ancoragem de armaduras de aço - Viga de concreto armado - Ashadi e Bouwkamp (1995). 


\subsubsection{Ligação viga-pilar misto com o uso de parafusos passantes}

Esse detalhe de ligação foi proposto por Prion \& Mclellan (1994) apud De Nardin (2003) e consiste da utilização de barras rosqueadas que são pós-tracionadas e chapa de extremidade da viga de aço. Os parafusos atravessam o tubo de aço e o núcleo de concreto até a outra extremidade do pilar. A transferência de esforços da viga para o pilar misto nesse tipo de ligação ocorre por forças de cisalhamento na interface aço-concreto (aderência e conectores). A Figura 2-11 apresenta a ligação proposta pelos autores.
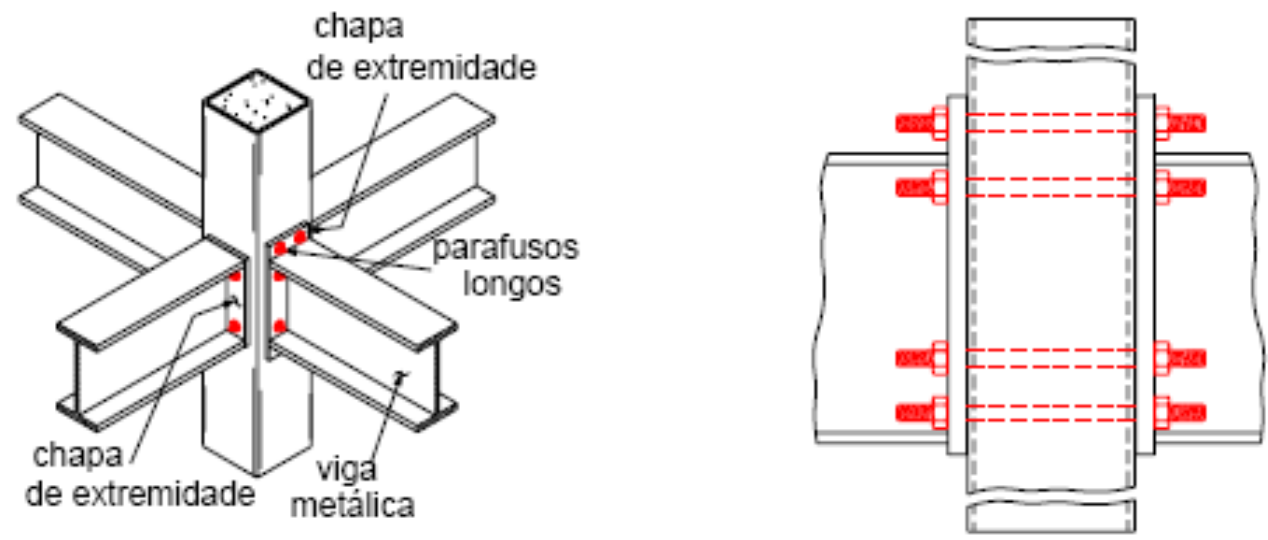

Figura 2-11 - Ligação com parafusos passantes (Prion \& Mclellan, 1994)

A ligação foi estudada com e sem aderência entre as barras e o núcleo de concreto. A diferença entre os dois modelos está na colocação dos parafusos, antes ou depois da concretagem. Para os elementos sem aderência, são inseridos tubos plásticos na moldagem do concreto para, posteriormente, serem inseridos os parafusos, quando o concreto se encontra em estado endurecido. No estudo realizado pelos autores, os parafusos eram submetidos apenas a esforços de cisalhamento.

De Nardin (2003) estudou o mesmo tipo de ligação com modelos com e sem aderência entre os parafusos passantes e o núcleo de concreto. Com base nos ensaios realizados foi observado que a presença ou não da aderência nos parafusos não interfere no comportamento Momento x Rotação da ligação. A ligação apresentou desempenho superior em relação à 
resistência e rigidez quando comparada com outras ligações estudadas no mesmo trabalho (ligações soldadas).

Silva (2006) analisou o mesmo tipo de ligação, principalmente no aspecto da transferência de tensões entre o tubo de aço e o núcleo de concreto do pilar misto. A análise experimental foi realizada com ensaios do tipo "push-out", onde o carregamento foi aplicado apenas no núcleo de concreto, ou seja, a transferência de forças entre os dois materiais ocorria por cisalhamento na interface. Foram analisados três modelos: um dos modelos sem conectores de cisalhamento no pilar misto e os outros dois com a variação do tipo de conector. Os conectores utilizados foram: conector tipo pino com cabeça (“stud bolt”) e cantoneiras soldadas à face interna do tubo de aço.

Na análise experimental foi observada que a transferência de tensões entre os dois materiais do pilar misto é pequena, para o modelo sem conectores, prejudicando o desempenho do pilar. A presença dos conectores melhorou a transferência de tensões entre aço e concreto, sendo que as cantoneiras resultaram em melhor desempenho.

A análise experimental apresentou uma série de dificuldades, principalmente na identificação da forma de ruína da ligação, que ocorreu devido à ruína dos parafusos, prejudicando a análise da transferência de tensões entre aço e concreto. Acredita-se que a presença da laje de concreto armado (ligação mista) pode contornar tal problema, já que a laje acrescenta rigidez à ligação.

\subsection{Considerações finais}

As características vantajosas e as propriedades específicas dos pilares mistos preenchidos podem possibilitar o crescimento da utilização do sistema estrutural e o tornar 
competitivo em vários tipos de estruturas. Alguns trabalhos experimentais criticam os códigos normativos por produzirem resultados conservadores e apontam como solução para a competitividade do sistema, o uso de métodos de cálculos, mais realistas que levem em consideração as não-linearidades do elemento, como o confinamento e as flambagem local e global.

O confinamento e o estudo dos pilares esbeltos são os assuntos mais abordados pelos pesquisadores. Em contrapartida, alguns assuntos são escassos de trabalhos, como a consideração da aderência entre o aço e o concreto. A grande maioria dos trabalhos é de caráter experimental, sendo e os poucos trabalhos de análise numérica não entram em maiores detalhes, necessários para dar continuidade a tais estudos.

As ligações entre o pilar misto e a viga de aço é outro assunto abordado apenas por meio de análise experimental. Como estas ligações são utilizadas em locais com grande probabilidade de abalos sísmicos, boa parte dos trabalhos aborda apenas o comportamento destas ligações para este tipo de solicitação.

Das ligações consideradas, percebe-se que as ligações internas, nas quais é realizada a ancoragem da ligação no núcleo de concreto, apresentam desempenho superior em resistência e rigidez, em relação às ligações externas mas, em contrapartida, estes são detalhes mais difíceis de executar e apresentam custo relativamente alto. 


\section{Capítulo 3}

\section{Aderência e mecanismos de transferência de forças}

\subsection{Apresentação}

São apresentados, neste capítulo, os principais aspectos referentes à aderência entre o aço e o concreto nos pilares mistos preenchidos e os mecanismos de transferência de forças entre estes materiais. A abordagem de tal tema apresenta importância, já que é por meio destes mecanismos que ocorre a transferência de forças no modelo de ligação estudado.

Inicialmente, são apresentados os principais aspectos da aderência no pilar misto preenchido, destacando a importância da aderência no comportamento estrutural desses elementos. Em seguida, os mecanismos de transferência de forças entre aço e concreto (adesão química, aderência mecânica e atrito) são descritos.

Posteriormente, alguns estudos experimentais a respeito da aderência nos pilares mistos preenchidos são relatados e discutidos. O comportamento dos conectores de cisalhamento também é abordado neste capítulo, dando maior ênfase ao conector tipo pino com cabeça, que foi um dos dispositivos mecânicos utilizados para promover o comportamento conjunto aço-concreto nos elementos investigados experimentalmente.

Por fim, a modelagem numérica da aderência entre aço e concreto é abordada. Apresentam-se alguns modelos numéricos encontrados na literatura técnica, destacando a representação da aderência por elementos de interface, já que foi a estratégia escolhida para a modelagem numérica. 


\subsection{Importantes aspectos da aderência no pilar misto preenchido}

Para o bom desempenho do pilar misto preenchido é necessária a garantia do trabalho conjunto de aço e concreto; caso contrário, o elemento não poderá ser considerado misto. Desta forma, um dos aspectos mais importantes em relação aos pilares mistos preenchidos é a capacidade de transferência de tensões de cisalhamento entre o concreto e o aço. Quando essa transferência de tensões no pilar misto não é promovida de forma eficaz, pode ocorrer concentração de tensões em um dos componentes, levando à ruína prematura do elemento estrutural.

A transferência de tensões entre o aço e o concreto requer atenção especial na região de introdução de cargas, na qual ocorre variação localizada de algum esforço solicitante, como nas ligações do pilar com a viga. A forma de introdução das cargas no pilar vai depender do tipo de vinculação do pilar com o restante da estrutura, como mostrado por Johansson (2001) na Figura 3-1. Para o caso da Figura 3-1a, onde não há continuidade dos pilares e, portanto, não há transferência de momento fletor da viga para o pilar, os esforços são transferidos da viga para o pilar com aplicação direta da carga nos dois componentes da seção por chapas de extremidade ou por outro mecanismo adequado.

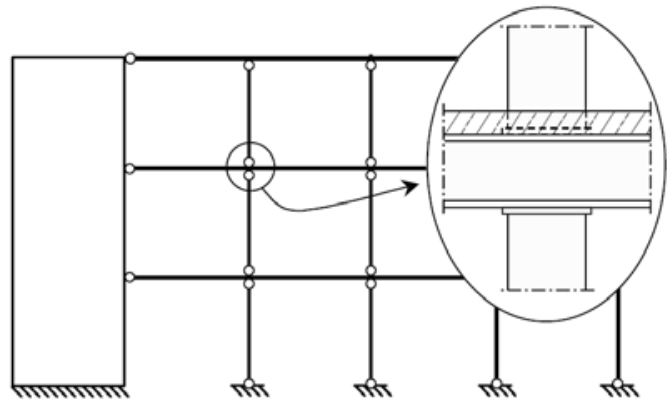

a) Pilares simplesmente apoiados

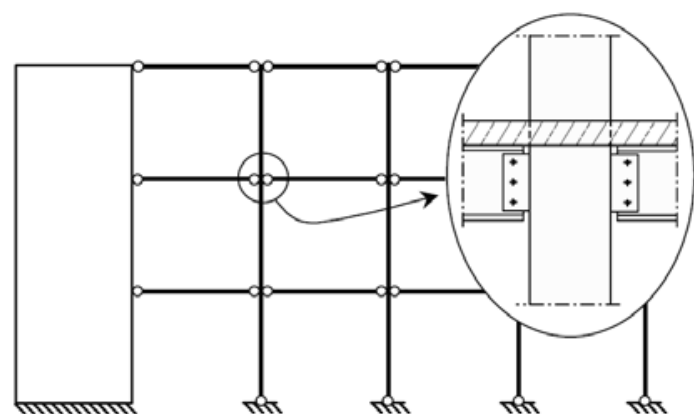

b) Pilares contínuos

Figura 3-1 - Condições de vinculação no pilar misto (JOHANSON, 2001) 
Para o caso da Figura 3-1b, a transferência de tensões entre os dois componentes da seção mista acontece pelos mecanismos de transferência de forças: adesão química, aderência mecânica e atrito. Nesta situação, é necessária a compatibilidade de deformações entre os dois materiais e a não ocorrência de deslizamento relativo significativo. Portanto, a capacidade da interface resistir ao cisalhamento é o fator preponderante para a ocorrência do equilíbrio de forças, sendo o momento fletor o responsável por mobilizar as tensões na interface, pois este gera um binário de forças na seção (Figura 3-2).

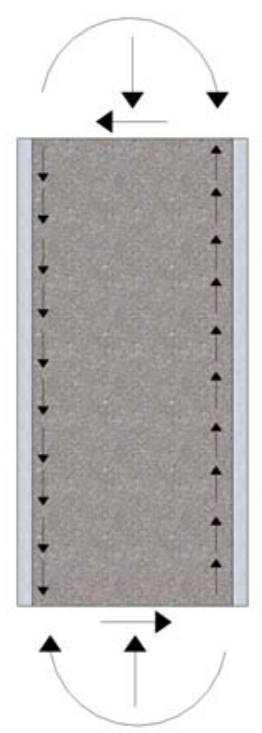

Figura 3-2 - Equilibrio na transferência de forças

Os estudos para o melhor entendimento do comportamento da aderência entre o aço e o concreto nos pilares mistos preenchidos, na maioria das vezes, são realizados por meio de ensaios experimentais do tipo "push-out” (Figura 3-3), onde é possível obter curvas de força e deslizamento relativo. A partir destas curvas é possível identificar, em alguns casos, as três parcelas teóricas da aderência (aderência química, aderência mecânica e atrito). Dentre os estudos realizados com esse enfoque destacam-se os trabalhos de Shakir-Khalil (1993a) e o de Parsley, Yura e Jirsa (2000) e no Brasil o estudo realizado por Silva (2006) merece destaque. 


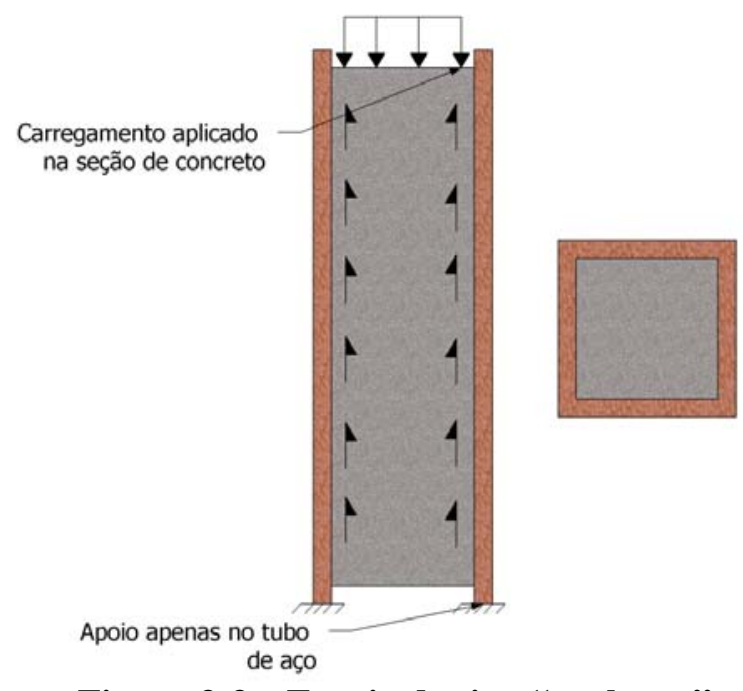

Figura 3-3 - Ensaio do tipo "push-out”

O grande problema dos ensaios do tipo "push-out" em pilares mistos preenchidos é a baixa representatividade do comportamento da aderência na região de introdução de cargas, justamente a região de maior interesse de conhecimento destes mecanismos. Situação mais realista foi estudada experimentalmente por Shakir-Khalil (1993b e 1994) onde ensaios do tipo "push-out" em pilares mistos preenchidos, cujos modelos representavam região de ligação viga-pilar. Silva (2006) além dos ensaios do tipo "push-out" em pilares mistos preenchidos de seção quadrada, realizou ensaios de modelos de ligação viga-pilar. Estes últimos são modelos físicos mais representativos, pois a rotação da ligação introduz efeitos importantes na interface aço-concreto. A rotação da ligação ocasiona esforços concentrados de compressão no concreto na região inferior da ligação e a separação dos dois materiais na interface (“uplift”) na região superior da ligação, como exposto na Figura 3-4. 


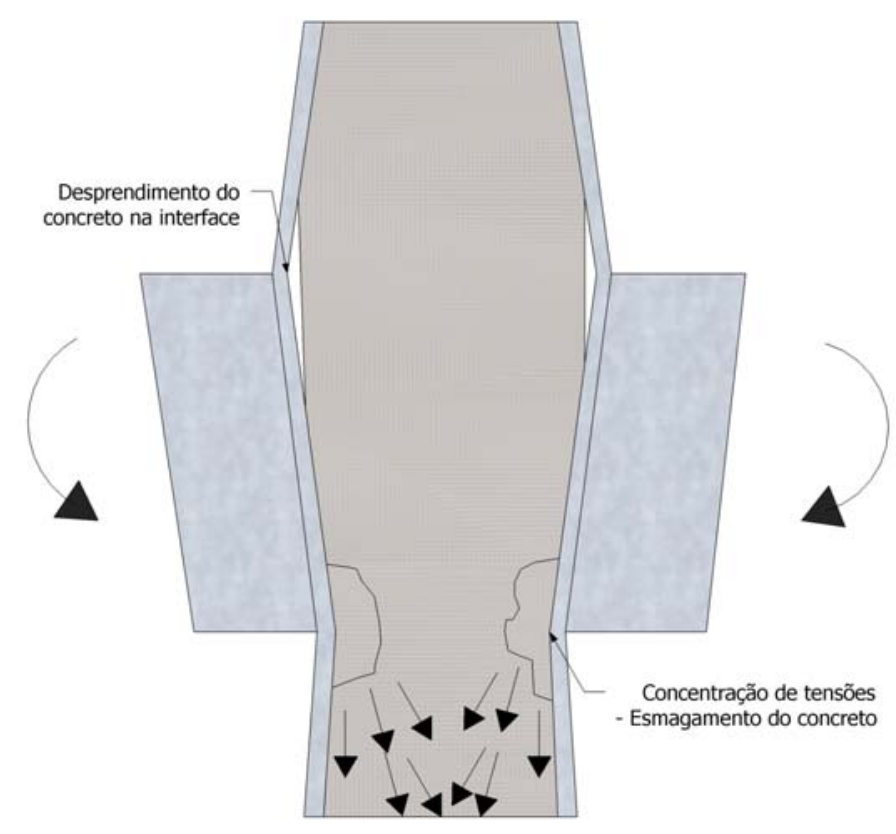

Figura 3-4 - Comportamento do pilar na ligação

No dimensionamento, os códigos normativos (PR - NBR 8800, EUROCODE 4 e AISC/ANSI 360) prescrevem que seja verificada se a tensão tangencial de cálculo supera a tensão resistente de aderência. Caso a tensão de cisalhamento ultrapasse a tensão resistente de aderência, devem ser previstos a utilização de conectores de cisalhamento para resistir aos esforços solicitantes de cisalhamento. Essa verificação deve ser realizada na região de introdução de cargas do pilar misto preenchido. Os valores de resistência de aderência recomendados pelos códigos normativos estão expostos na Tabela 3-1. O comprimento de introdução de cargas é dado pelo PR - NBR 8800 (2007) e pelo EUROCODE 4 (2004) como sendo duas vezes a menor dimensão da seção do pilar misto ou $1 / 3$ do comprimento do pilar, adotando o que for menor. Para o AISC/ANSI 360 (2005) o comprimento de introdução de cargas é tomado como apenas duas vezes a menor dimensão da seção do pilar.

O esforço solicitante na região de introdução de cargas vai depender do tipo de ligação utilizado. O PR-NBR 8800 (2007) apresenta um procedimento para obter a solicitação de cálculo na região de introdução de cargas (Tabela 3-2). 
Tabela 3-1 - Resistência de aderência

\begin{tabular}{|c|c|c|}
\hline \multirow{5}{*}{ PR - NBR 8800 (2007) e EUROCODE 4 (2004) } & $\begin{array}{l}\text { Pilar misto totalmente } \\
\text { revestido }\end{array}$ & $0,3 \mathrm{MPa}$ \\
\hline & $\begin{array}{l}\text { Pilar misto preenchido } \\
\text { circular }\end{array}$ & $0,55 \mathrm{MPa}$ \\
\hline & $\begin{array}{l}\text { Pilar misto preenchido } \\
\text { retangular }\end{array}$ & $0,4 \mathrm{MPa}$ \\
\hline & $\begin{array}{l}\text { Pilar misto } \\
\text { parcialmente revestido } \\
\text { (Mesas) }\end{array}$ & $0,2 \mathrm{MPa}$ \\
\hline & $\begin{array}{l}\text { Pilar misto } \\
\text { parcialmente revestido } \\
\text { (Alma) }\end{array}$ & $0 \mathrm{MPa}$ \\
\hline \multirow{2}{*}{ ANSI/AISC 360/05 } & Pilar misto preenchido & $0,4 \mathrm{MPa}$ \\
\hline & Pilar misto revestido & $0 \mathrm{MPa}$ \\
\hline
\end{tabular}

Tabela 3-2 - Esforços solicitantes de cálculo na região de introdução de cargas (PR-NBR 8800, 2007)

$$
V_{S d . l}=V_{S d}\left(1-\frac{N_{R d a, p l}}{N_{R d, p l}}\right)
$$

Viga ligada apenas no perfil de aço

Viga ligada apenas no concreto do pilar

$$
\begin{aligned}
& M_{S d . l}=M_{S d}\left(1-\frac{M_{R d a, p l}}{M_{R d, p l}}\right) \\
& V_{S d . l}=V_{S d}\left(\frac{N_{R d a, p l}}{N_{R d, p l}}\right) \\
& M_{S d . l}=M_{S d}\left(\frac{M_{R d a, p l}}{M_{R d, p l}}\right)
\end{aligned}
$$

Onde:

$V_{S d . l}$ : Força cortante solicitante de cálculo no comprimento de introdução de carga

$V_{S d}$ : Força cortante solicitante de cálculo na ligação

$M_{S d . l}$ : Momento fletor solicitante de cálculo no comprimento de introdução de carga

$M_{S d}$ : Momento fletor solicitante de cálculo na ligação

$N_{R d a, p l}$ : Força axial resistente de cálculo do perfil de aço à plastificação total

$N_{R d, p l}$ : Força axial resistente de cálculo do pilar misto à plastificação total

$M_{R d a, p l}$ : Parcela do momento fletor resistente de cálculo do perfil de aço à plastificação total

$M_{R d, p l}$ : Momento fletor resistente cálculo do pilar misto à plastificação total

Caso sejam utilizados conectores de cisalhamento na interface, o PR-NBR 8800 (2007) e o EUROCODE 4 (2004) permitem adicionar à tensão resistente de aderência, uma 
parcela de resistência devida as forças de atrito dos conectores de cisalhamento. Nos trechos entre as regiões de introdução de carga é necessário prever conectores de cisalhamento para garantir o fluxo de cisalhamento entre a interface e o aço, apenas para o caso onde a resistência de aderência for inferior aos esforços solicitantes de cálculo.

\subsection{Mecanismos de transferência de forças}

Diversos autores idealizam que os mecanismos de transferência de forças de cisalhamento através da aderência possam ser subdivididos em três parcelas distintas. (Figura $3-5)$

- Aderência química ou adesão

- Aderência mecânica

- Atrito

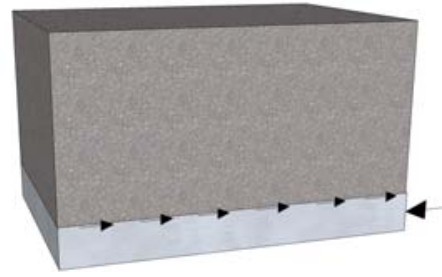

a) Aderência química ou Adesão

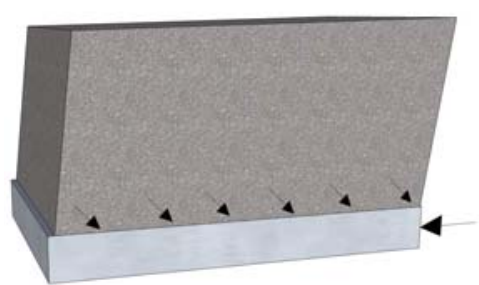

b) Aderência mecânica

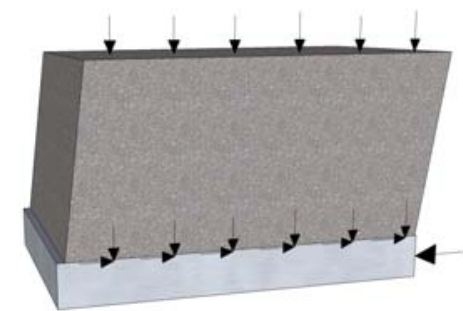

c) Atrito

Figura 3-5 - Mecanismos idealizados de transferência de forças

\subsubsection{Aderência química ou adesão}

A aderência química ou adesão é considerada um mecanismo frágil eliminado nos estágios iniciais de carregamento e tem relação direta com as propriedades do concreto, sendo produzida ao longo da interface dos dois materiais pelas reações químicas do cimento na sua hidratação. Nos diagramas força-deslizamento de ensaios do tipo "push-out", a adesão pode 
ser facilmente percebida e diferenciada dos demais mecanismos, pois a ruína da adesão por ocorrer para pequenos deslocamentos. Segundo Johansson (2000), nos pilares mistos preenchidos as forças resistentes devida à adesão química são vencidas quando o deslocamento relativo entre o concreto e aço atinge valores da ordem de $0,01 \mathrm{~mm}$. A resistência da adesão química é diretamente influenciada pela retração e pela compactação do concreto (HAN; YAO, 2003).

\subsubsection{Aderência mecânica}

A aderência mecânica se manifesta em conjunto com o atrito, de forma que alguns autores consideram ambos um só fenômeno. A aderência mecânica está ligada à rugosidade do tubo de aço, sendo mobilizada pelo micro engrenamento entre o concreto e a superfície irregular do tubo de aço. Desta forma, quanto maior a rugosidade da superfície interna do tubo de aço, maior a parcela resistente atribuída à aderência mecânica.

Virdi e Dowling (1980) estudaram a aderência em pilares mistos preenchidos de seção circular e observaram que a ruptura da aderência mecânica ocorre quando o concreto atinge deformações de aproximadamente de $0,35 \%$ na interface, ou seja, quando ocorre o esmagamento local do concreto.

$\mathrm{Na}$ análise experimental realizada por Shakir-Khalil (1993b), foi observado que a presença das ligações viga-pilar em ensaios do tipo "push-out" aumenta a contribuição da aderência mecânica, pois tais ligações introduzem a rotação no mecanismo.

A mesma observação foi feita por Parsley, Yura e Jirsa (2000) nos elementos ensaiados com a presença das ligações, nos quais ocorreu uma contribuição maior da aderência mecânica devido à rotação das ligações. Os mesmos autores afirmam que a aderência mecânica apenas contribui de forma significativa na região das ligações, pois nos ensaios de "push-out” em modelos de pilar essa contribuição pode ser desprezada. 


\subsubsection{Atrito}

O atrito se manifesta após a ruptura da adesão entre o aço e o concreto, e depende da força normal aplicada na interface e do coeficiente de atrito entre os dois materiais.

Jonhanson (2000) afirma que o coeficiente de atrito nos pilares mistos preenchidos varia entre 0,2 a 0,6 , mas a utilização do valor médio 0,6 pode ser mais adequado para a análise de modelos numéricos e analíticos de pilares mistos preenchidos. O mesmo autor subdivide o atrito em duas parcelas: atrito passivo e atrito ativo, sendo que o atrito passivo corresponde à parcela referente à aderência mecânica entre os dois materiais.

Shakir-Khalil (1993b) afirma que a parcela de atrito em pilares mistos preenchidos de seções retangulares ou quadradas é pequena e se manifesta apenas nos cantos da seção, sendo maior em pilares de seção circular, onde o atrito se manifesta em todo o perímetro do tubo de aço.

Diferentemente dos outros mecanismos de transferência de forças, que apresentam alto grau de variação ao longo do comprimento do pilar, o atrito tende a ser quase constante (PARSLEY; YURA; JIRSA, 2000).

Johansson (2000) apresenta outros mecanismos externos que influem diretamente no comportamento da aderência (Figura 3-6), como a curvatura do pilar, variações na dimensão do tubo de aço e micro-irregularidades na superfície interna do tubo de aço. 


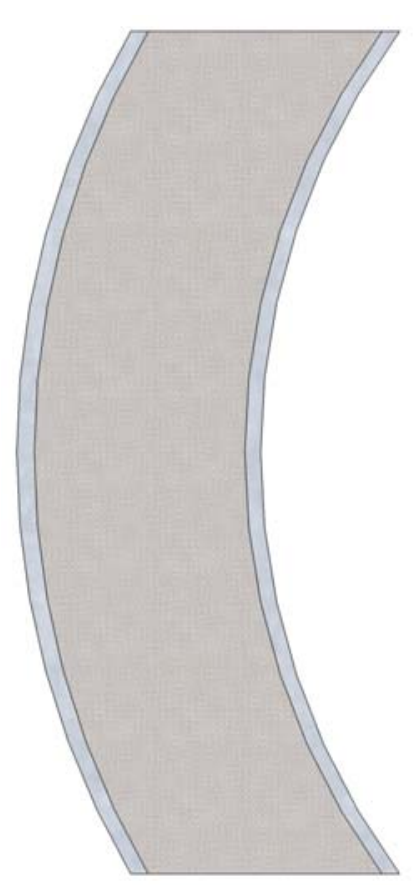

a) Curvatura do pilar

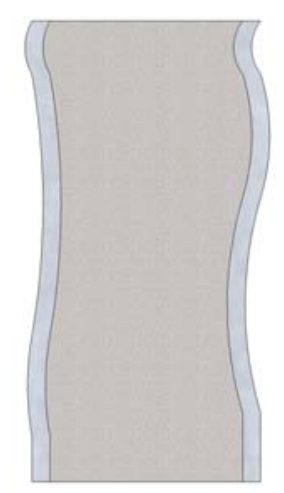

b) Variações do tubo de aço ao longo do seu comprimento

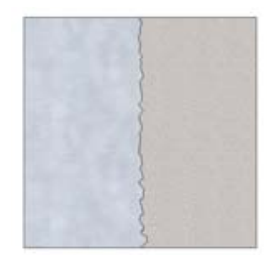

b) Micro irregularidades na superfície de contato entre os materiais

Figura 3-6 - Mecanismos externos que influem na resistência de aderência dos pilares mistos

\subsection{Aderência nos pilares mistos preenchidos}

$\mathrm{Na}$ análise do comportamento estrutural dos pilares mistos preenchidos é considerada a aderência total entre os dois materiais, admitindo-se a continuidade integral das deformações e a manutenção da integridade da interface entre os dois materiais. A importância da aderência no comportamento estrutural dos pilares mistos preenchidos começou a ser estudada por volta de 1980 com o trabalho desenvolvido por Virdi e Downling (1980). Ao longo dos anos, diversos trabalhos experimentais foram realizados enfocando a aderência entre o aço e o concreto, em sua maioria através de ensaios do tipo "push-out".

Com o intuito de avaliar o papel da aderência, alguns trabalhos experimentais foram realizados onde a aderência era retirada de algumas amostras com a aplicação de produtos químicos ou filme plástico na interface de contato dos dois materiais, desta forma foi possível comparar estes resultados com de pilares mistos com aderência entre o aço e o concreto. 
Um destes estudos se destaca o realizado por Kilpatrick e Rangan (1990). Neste trabalho os autores realizaram ensaios em pilares mistos de seção circular, com a variação da aderência em três níveis (máxima, parcial e mínima). A aderência máxima era realizada através da colocação de pinos e nervuras na região interna do tubo de aço e a mínima foi realizada através da retirada da adesão química entre os dois materiais pela aplicação de óleos na superfície interna. A chamada aderência parcial se tratava apenas da aderência natural entre a pasta de cimento e o tubo de aço. Nos ensaios foi variado o comprimento do pilar misto. Os resultados indicaram que a aderência só trazia efeitos benéficos em relação a resistência para pilares muito curtos. À medida que se aumentava o comprimento do pilar o nível de aderência entre os dois materiais não influenciou na capacidade resistente do pilar misto. A Tabela 3-3 mostra os resultados experimentais obtidos pelos autores.

Tabela 3-3 - Resultados experimentais de Kilpatrick e Rangan (1999)

\begin{tabular}{|c|c|c|c|}
\hline & $\begin{array}{c}\text { Pilares curtos } \\
\mathrm{L} / \mathrm{D}=3,5 \\
\mathrm{Nmax}(\mathrm{kN})\end{array}$ & $\begin{array}{c}\text { Pilares medianamente } \\
\text { esbeltos } \\
\mathrm{L} / \mathrm{D}=10 \\
\text { Nmax }(\mathrm{kN})\end{array}$ & $\begin{array}{c}\text { Pilares esbeltos } \\
\text { L/D }=19 \\
\text { Nmax }(\mathrm{kN})\end{array}$ \\
\hline Aderência máxima & 1063 & 442 & 287 \\
\hline Aderência parcial & 1020 & 450 & 290 \\
\hline Aderência mínima & 990 & 440 & 299 \\
\hline
\end{tabular}

Como dito anteriormente, Virdi e Dowling (1980) realizaram um dos primeiros trabalhos enfocando a aderência nos pilares mistos preenchidos. $\mathrm{O}$ estudo de caráter experimental analisou pilares curtos de seção circular utilizando ensaios do tipo "push-out", e variando a resistência à compressão e a idade do concreto, comprimento e diâmetro do tubo de aço. Foi avaliada também a tecnologia de obtenção do concreto (adensamento) e do tubo de aço e sua influência na aderência, já que a rugosidade interna do tubo de aço é peça fundamental no mecanismo de atrito. Em alguns dos modelos foram aplicados lubrificantes para reduzir a influência da aderência. Os resultados indicaram que a ruptura da aderência ocorre quando o concreto atinge uma deformação de $0,2 \%$ a $0,4 \%$. A ruptura dos modelos 
cuja aderência foi reduzida por lubrificante ocorreu praticamente com a mesma força verificada nos demais modelos, mas a redução da aderência eliminar a rigidez inicial devido à adesão química. Em relação às propriedades do concreto, foi observado que a resistência de aderência cresce à medida que cresce a resistência à compressão do concreto e a idade do concreto, pois para concretos com mais de 21 dias ocorreu decréscimo da resistência de aderência. Os autores destacam também que o adensamento correto do concreto pode aumentar a resistência de aderência. Em relação às propriedades geométricas (comprimento e espessura do tubo) não houve variação da resistência da aderência. A principal conclusão do estudo foi que o atrito é o mecanismo predominante, principalmente próximo à ruína do pilar misto.

Através de análise experimental, Cederwall, Engstron \& Grauers (1990) observaram que a aderência influencia a ductilidade dos pilares mistos preenchidos, principalmente quando se utiliza concreto de alta resistência. No estudo, a análise experimental foi realizada com ensaios de compressão axial, variando a forma de aplicação da carga (na seção de concreto, no tubo de aço e na seção mista) e utilizando concreto de alta resistência. A redução da aderência foi realizada com a utilização de filme plástico na interface dos dois materiais e foi verificado que os modelos com aderência apresentaram melhor desempenho para carregamento axial. O efeito benéfico é referente ao aumento da rigidez do pilar, foi comprovado que a aderência não aumenta de forma significa a resistência do pilar misto.

Apesar da comprovação do efeito benéfico da aderência no comportamento estrutural do pilar misto preenchido, a aderência não traz contribuição aos pilares mistos preenchidos flexo-comprimidos (OKAMATO; MAENO, 1988). Uma alternativa para que a aderência contribua na flexo-compressão, é inserir nervuras internas no tubo de aço (MATUMARA; MATAI, 1992). 
Shakir-Khalil (1993a e 1993b) realizou diversos ensaios experimentais do tipo "pushout" em pilares mistos preenchidos de seções circular e quadrada, com e sem conectores de cisalhamento. Em alguns elementos amostras a aderência foi reduzida com a aplicação de óleo na superfície interna do perfil de aço. Além de modelos de pilar, foram analisados modelos de ligação, que permitiram obter as seguintes conclusões:

- A aderência contribui para o comportamento mecânico dos pilares mistos preenchidos, já que os pilares cuja aderência foi reduzida apresentaram um desempenho mecânico pior quando comparados com as outras amostras.

- A parcela de transferência devido ao atrito entre o aço e o concreto torna-se mais evidente nos pilares de seção circular, pois atuam em toda a face de contato do tubo metálico. Nos pilares de seção quadrada estes mecanismos são mais pronunciados nos cantos do tubo de aço. Com isso, a resistência de aderência é maior nos pilares de seção circular.

- Os valores da resistência de aderência apresentaram alta variabilidade com elementos apresentando valores entre $0,2 \mathrm{MPa}$ e $0,9 \mathrm{MPa}$, para o mesmo tipo de concreto.

- Quanto menor a dimensão da seção transversal, maior a resistência de aderência. Quanto ao comprimento do tubo de aço, não afeta de forma significativa o valor da resistência da aderência. Portanto a espessura e as dimensões da seção transversal do tubo afetam diretamente o comportamento da aderência.

- A curva que relaciona a carga aplicada com o deslocamento do núcleo do concreto apresenta, na maioria das vezes, comportamento bi-linear para os modelos sem conectores. 
Parsley, Yura e Jirssa (2000) também analisaram a aderência em pilares mistos preenchidos por meio de ensaios do tipo "push-out". Os resultados demonstraram que quanto maior a espessura do tubo de aço, maior a tensão resistente de aderência e desta forma maior a contribuição da aderência no comportamento do pilar misto. Em função dos resultados os autores sugerem que a tensão resistente de aderência seja relacionada com a espessura do tubo e com as dimensões do núcleo de concreto nos códigos normativos.

Outro fator que contribui de forma significativa para a aderência em pilares mistos preenchidos são as imperfeições geométricas, tanto a rugosidade da parede do tubo de aço, como a variação da seção transversal ao longo do comprimento do pilar. O fato de a aderência ser menor em tubos de paredes finas tem relação direta com o fato destes tubos apresentarem maior flexibilidade, possibilitando o surgimento de imperfeições (SHANMUGAM; LAKSMI, 2001).

Han e Yao (2003) afirmam que parte dos resultados sobre a aderência em pilares mistos preenchidos acaba sendo mascarada por ser desprezada a influência da compactação e de outras propriedades do concreto, sendo esta a principal causa da grande variabilidade de resultados encontrada na literatura. $\mathrm{O}$ estudo realizado pelos autores indica que concretos com boa compactação apresentam aumento expressivo da resistência de aderência. Resultado semelhante ao apresentado por Virdi e Dowling (1980). Além disso, a boa compactação do concreto nos pilares mistos preenchidos aumenta a capacidade resistente e melhora as condições de estabilidade. Os resultados indicam um ganho de $20 \%$ a $30 \%$ da capacidade resistente da coluna quando o concreto apresenta uma boa compactação. 


\subsection{Conectores de cisalhamento}

O comportamento dos elementos mistos de aço e concreto é fundamentado no trabalho conjunto dos seus componentes. Por este motivo, deve-se garantir que a transferência de tensões cisalhantes seja realizada de forma adequada. Como a ruína da aderência química ocorre com baixos níveis de carregamento, podem ser utilizados dispositivos mecânicos como os conectores de cisalhamento para garantir o comportamento conjunto do elemento estrutural.

O que determina o comportamento do conector de cisalhamento no elemento misto é o seu grau de conexão, que pode ser avaliado de acordo com a resistência e com a rigidez. $\mathrm{O}$ grau de conexão é determinado pela relação entre a capacidade resistente do conector ao momento fletor e a capacidade resistente da seção mista. A Figura 3-7 ilustra os graus de conexão de uma viga mista.
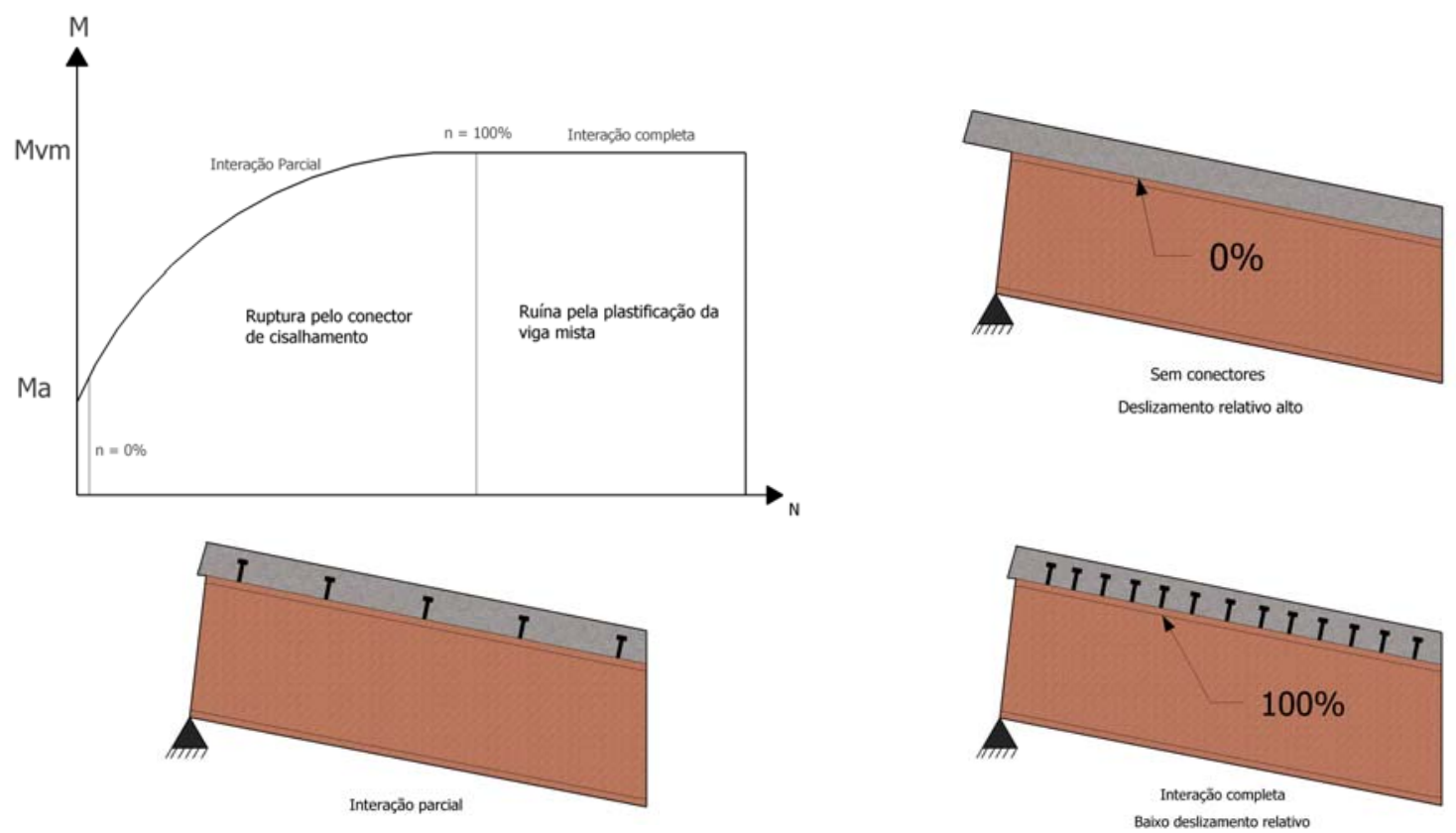

Figura 3-7 - Graus de interação - conectores de cisalhamento

Quando o elemento misto (no caso uma viga mista) não possui conectores de cisalhamento $(\eta=0 \%)$, os dois materiais atuam de forma separada, desta forma tendo duas 
linhas neutras cortando a seção mista. Para este caso o deslizamento relativo entre os dois materiais é alto e o não aproveitamento correto da seção resistente de concreto ocasiona no aumento da viga metálica. Para interação parcial $(0 \%<\eta<100 \%)$ a capacidade resistente da viga é limitada pela ruptura no conector de cisalhamento. Para o caso de interação total $(\eta=$ 100\%) apenas uma linha neutra corta a seção e o alto grau de conexão faz com que a capacidade resistente do elemento seja governada pela resistência da viga metálica. Neste ponto a adição de conectores e o aumento do grau de interação $(\eta>100 \%)$ não acrescentam resistência ao elemento misto.

O grau de interação é determinado pela resistência e pela quantidade de conectores e pela rigidez dos elementos (viga metálica e laje de concreto). Quanto maior o grau de interação, menor o deslizamento relativo e consequentemente maior a rigidez, embora em casos práticos a não ocorrência de deslizamento relativo entre os dois materiais não é possível, pois a ductilidade dos conectores exige que este sejam mobilizados apenas quando já atingiu um determinado nível de carga e consequentemente um deslizamento relativo. A Figura 3-8 ilustra a relação de rigidez com o grau de interação dos conectores.

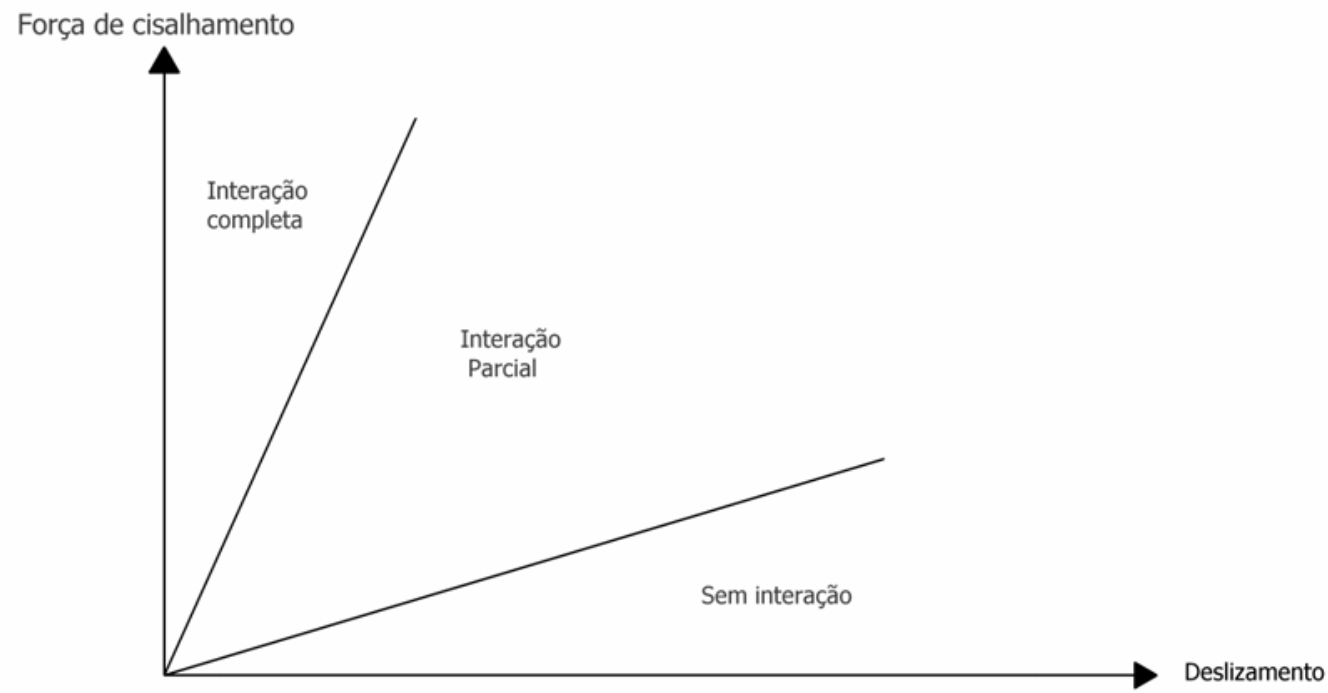

Figura 3-8 - Graus de interação de acordo com a rigidez 
A caracterização do comportamento dos conectores de cisalhamento pode ser determinada através da sua curva força $\mathrm{x}$ deslizamento relativo (Figura 3-9), onde esta consegue demonstrar as suas principais propriedades:

- Rigidez inicial

- Resistência máxima

- Capacidade de deformação

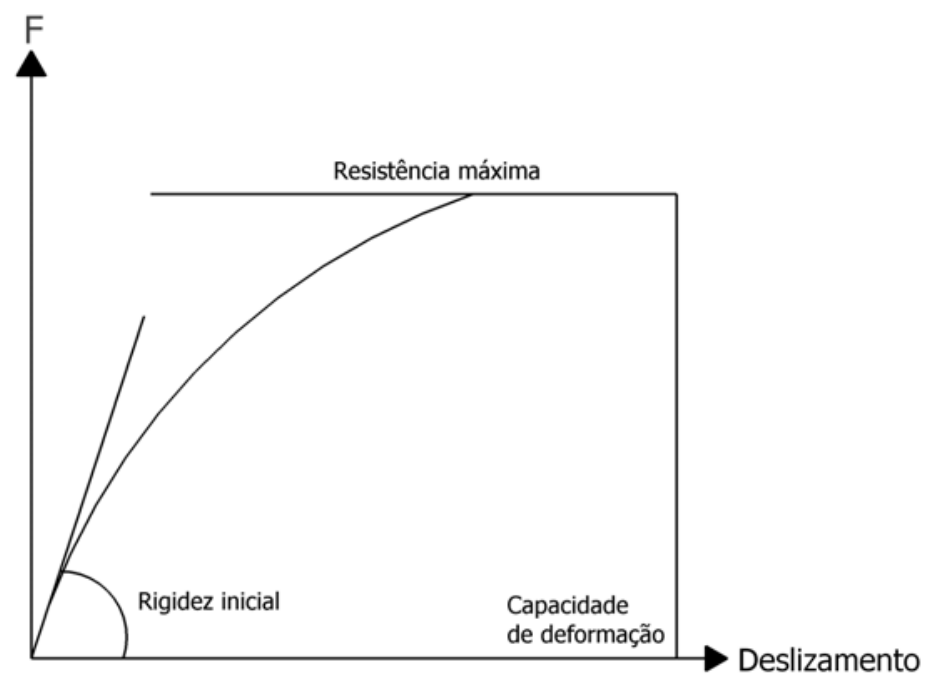

Figura 3-9 - Curva força $x$ deslizamento relativo do conector de cisalhamento

O conector de cisalhamento mais utilizado é o tipo pino com cabeça (Figura 3-10) ou "stud bolt" (OLLGARD; SLUTTER; FISCHER, 1971). Desenvolvido na década de 40 pela Nelson Stud Welding, o conector consiste de um pino projetado para soldagem por arco elétrico com cabeça de diâmetro padronizado.

Os conectores normalmente possuem comportamento dúctil, sendo mobilizados apenas após a ruptura da adesão química entre aço e concreto. Em ensaios experimentais do tipo "push-out" em pilares mistos preenchidos é observada uma concentração de tensões no tubo de aço logo abaixo dos conectores A eficiência dos conectores depende do tipo de seção, do posicionamento dos conectores e da resistência de aderência (SHAKIR-KHALIL, 1993b). 


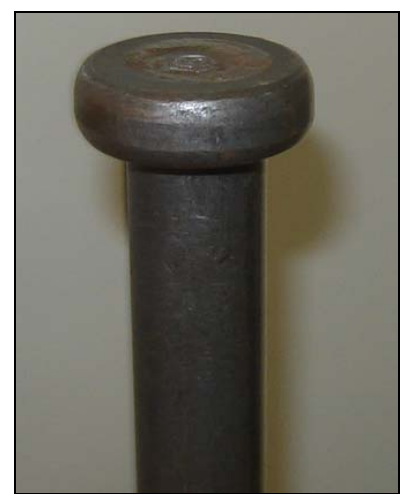

Figura 3-10 - Conector tipo pino com cabeça

SHIM, LEE \& CHANG (2001) afirmam que a resistência última dos conectores tipo pino com cabeça depende das propriedades do concreto (resistência à compressão e módulo de elasticidade), da área da cabeça do conector e de sua resistência à tração. As propriedades do concreto influem no comportamento do conector, já que em grande parte das vezes a ruína ocorre por esmagamento do concreto. Desta forma, para concretos de alta resistência, a resistência dos conectores depende apenas de suas propriedades. Na Figura 3-11 são apresentados os modos de falha que podem ocorrer nos conectores de cisalhamento tipo pino com cabeça imersos no concreto (Shim, Lee \& Yoon, 2004).

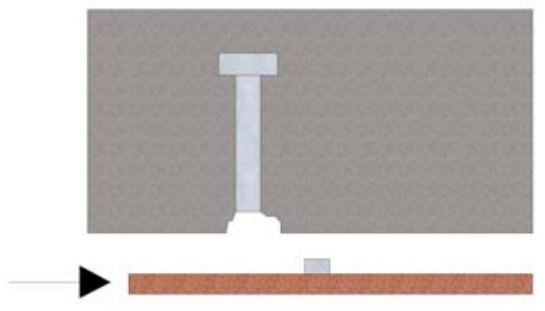

a) Ruína do concreto governada pelo conector de cisalhamento

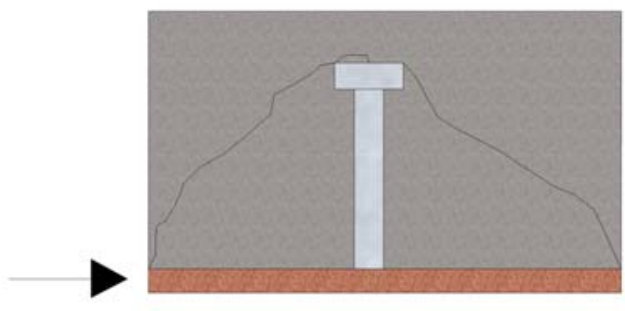

b) Ruína governada pelas propriedades do concreto - esmagamento

Figura 3-11 - Modos de falha possíveis nos conectores de cisalhamento

O PR - NBR 8880 (2007) permite a utilização do conector tipo pino com cabeça e de perfis laminados de seção "U" como conectores de cisalhamento. Na determinação da resistência do conector são considerados os modos de falha: ruptura do conector de 
cisalhamento ou esmagamento do concreto. A Tabela 3-4 apresenta as expressões de cálculo da resistência dos conectores por algumas normas.

Tabela 3-4 - Força resistente de conectores tipo pino com cabeça

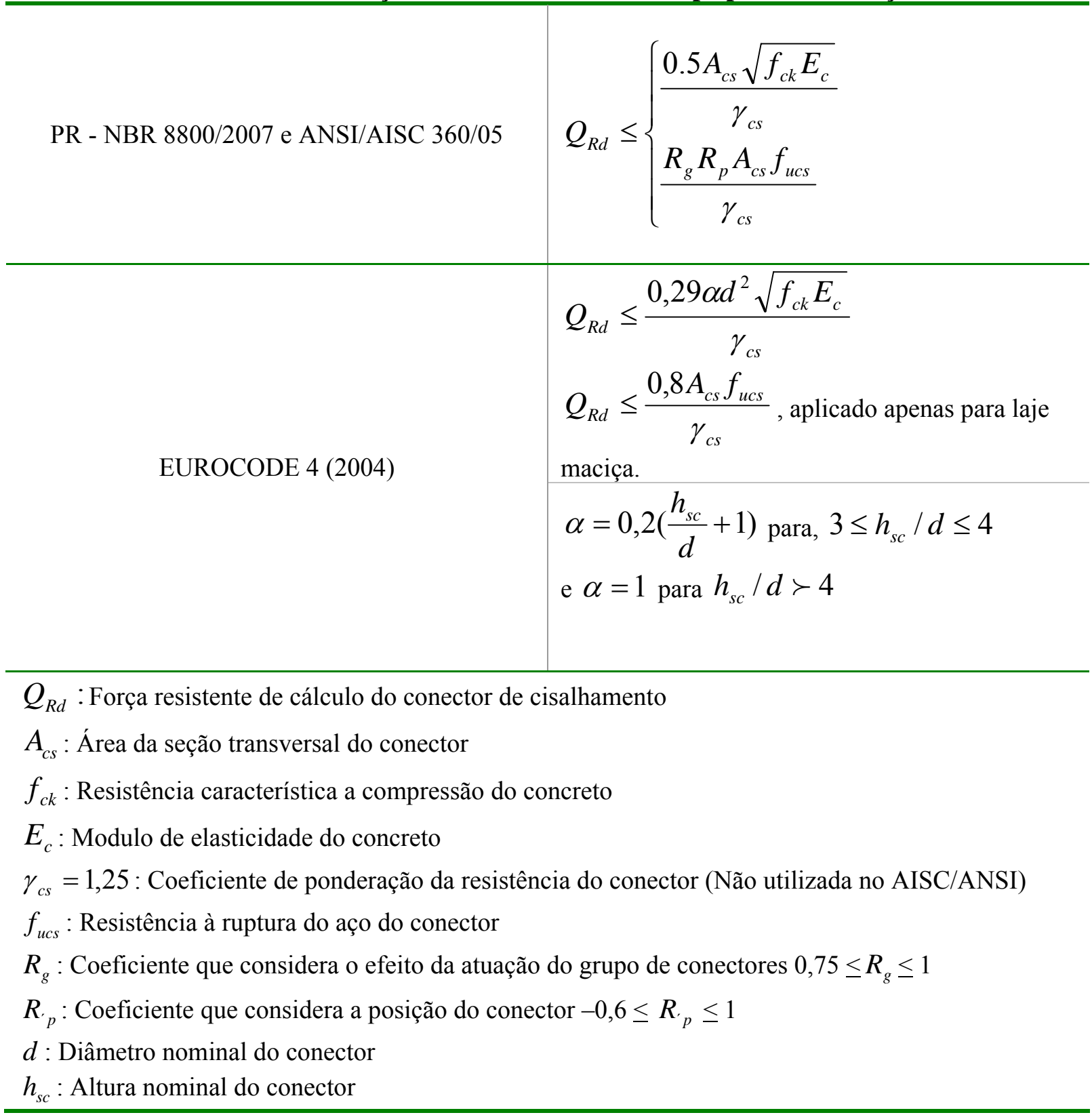

Na literatura técnica são encontrados outros tipos de conectores de cisalhamento como o Perfonbond rib (VALENTE; CRUZ, 2004) e os conectores tipo HVB (QUEIROZ; PIMENTA, 2001). Outra alternativa é a utilização de perfis metálicos soldados nos elementos estruturais funcionando como um conector (perfis "T"ou perfis cantoneiras), ou ainda usar 
alternativas para conectores de cisalhamento, como a apresentada por Higgin e Mitchell (2001).

\subsection{Modelagem numérica da interface aço-concreto}

A análise numérica dos sistemas mistos aço-concreto apresenta um alto grau de complexidade, tanto pelo comportamento não-linear dos materiais como pela sua interação. $\mathrm{O}$ concreto é um material frágil que tem respostas diferentes frente a solicitação de tração ou de compressão. Sua resistência à tração é pequena, sendo até negligenciada pelos códigos normativos. No comportamento à compressão, o concreto apresenta significativa mudança de rigidez quando atinge cerca de $50 \%$ de sua resistência; depois de atingido o pico de resistência o concreto assume comportamento de amolecimento. Outros efeitos não-lineares são observados no concreto como a fissuração, deformação lenta, confinamento e expansão lateral não-linear.

O aço possui comportamento caracterizado como elasto-plástico tanto na tração como na compressão. A modelagem da interação entre os dois materiais nos sistemas mistos possui comportamento altamente não-linear, sendo necessária à caracterização da interface da forma mais realista possível, para que a resposta do modelo numérico seja coerente com o seu comportamento real.

$\mathrm{Na}$ aderência entre aço e concreto, o aumento das tensões cisalhantes na interface ocasiona o surgimento de diversas fissuras no concreto próximo à interface. $\mathrm{O}$ aparecimento de uma macro-fissura na interface caracteriza a separação entre os dois materiais. Após a perda da aderência, ocorre um deslizamento relativo e a perda da capacidade de transferência de tensões entre os dois materiais (SOH, CHIEW e DONG, 1999). 
De uma forma geral o comportamento da interface pode ser modelado numericamente por meio um modelo de atrito, como o modelo de Coulomb. O modelo de atrito de Coulomb baseado no modelo de plasticidade de Mohr-Coulomb, pode ser utilizado para caracterizar tal comportamento. A caracterização do critério é realizada pelos valores da coesão e do ângulo de atrito interno. A Figura 3-12 representa o critério de atrito de Coulomb, onde "c" é a coesão, $\varphi$ é o ângulo de atrito, $t_{t}$ é a tensão tangencial, $t_{n}$ é a tensão normal e $f_{t}$ é a resistência à tração do material (neste caso do concreto).

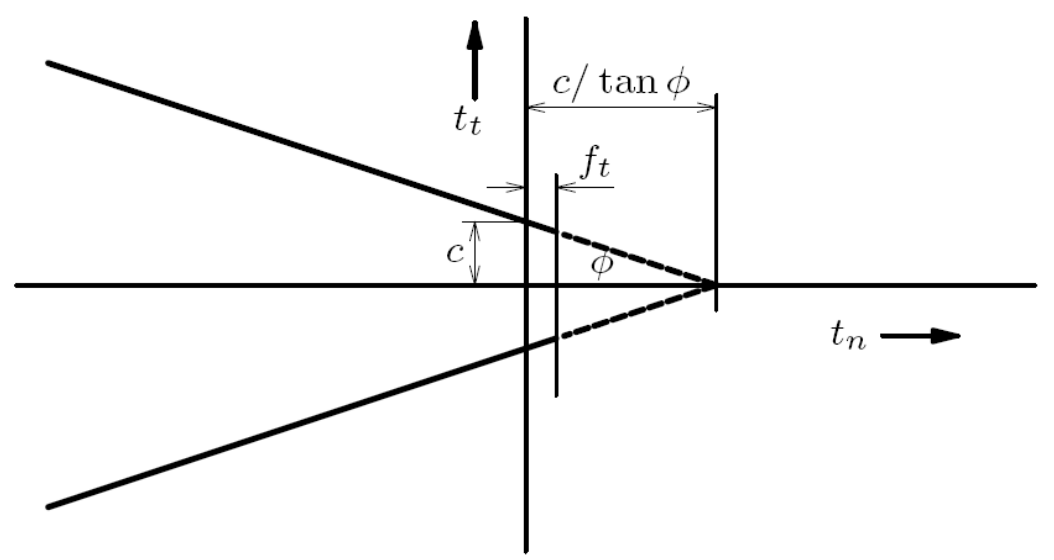

Figura 3-12 - Critério de atrito de Coulomb

Apesar deste modelo ser bastante utilizado, diversos autores ressaltam sua sensibilidade numérica em aplicações práticas e a apresentação de diversos problemas de convergência.

Outra forma de caracterizar o comportamento da aderência aço-concreto é a sua representação através de curvas do tipo "bond-slip", que representam a relação entre tensão de cisalhamento e deslizamento relativo entre os materiais. A obtenção de tal relação pode ser feita experimentalmente através de ensaios de arrancamento ("pull-out test"), que são realizados normalmente em problemas de aderência entre as armaduras de aço e o concreto, em estruturas de concreto armado. 
Yankelevsky (1985), utilizando equações de equilíbrio de forças que atuam na interface aço-concreto, propôs um método para a caracterização da curva "bond-slip". A curva é dividida em trechos ou zonas que caracterizam o comportamento de tal situação, senso que as condições para satisfazer as equações de equilíbrio podem ser obtidas experimentalmente. A partir desta estratégia o autor pôde criar um elemento finito que considera a aderência e o deslizamento na interface aço-concreto.

Kevser \& Mehlhorn (1987) apresentam a modelagem de problemas de aderência utilizando elementos finitos e ressaltam que o tipo de elemento mais simples para a modelagem do problema de aderência foi desenvolvido por Ngo \& Scordelis em 1967 e denominado de "elemento de ligação" (bond-link element). Este elemento finito não possui dimensões e representa a ligação da interface por elementos de mola que representam a rigidez da interface nas duas direções (Figura 3-13).

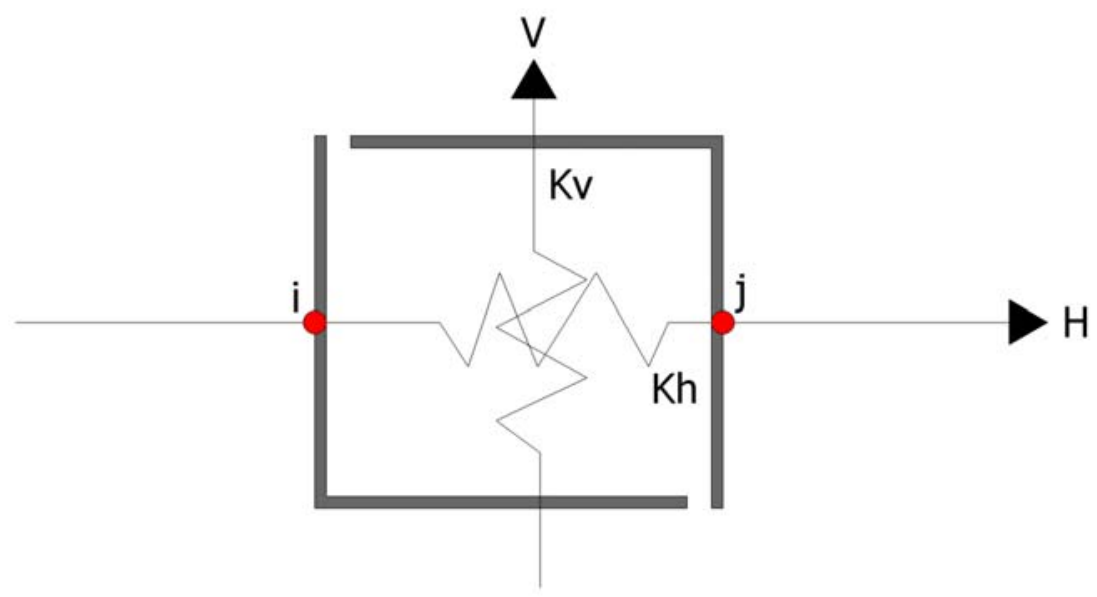

Figura 3-13 - Elemento de ligação (Ngo e Scordelis)

Em análises numéricas de elementos mistos, dois tipos de modelos podem ser adotados para a interface: modelos com aderência perfeita ou com aderência parcial. Os modelos com aderência parcial tendem a ser mais realistas e apresentam os melhores resultados. A modelagem do comportamento da interface aço-concreto deve ser realizada de 
forma coerente, já que a interação entre os materiais interfere no comportamento estrutural do elemento como deslocamento e modo de ruína (JEONG, KIM \& KIM, 2005).

A inclusão dos conectores de cisalhamento no modelo numérico é outro aspecto importante (espaçamento, quantidade e características). Dependendo do grau de precisão requerido na análise, pode ser utilizado um modelo com aderência perfeita entre os materiais; isto se for considerada a interação total (SPACONE \& EL-TAWIL, 2004).

Um modelo mais simples para a simulação dos conectores, apresentado por Spacone e El-Tawil (2004), consiste na utilização de elementos de mola com a rigidez dos conectores (Figura 3-14). Neste modelo, as molas podem ser distribuídas ao longo do elemento estrutural ou serem dispostas localmente. A análise é feita apenas na direção tangencial, desprezando o deslocamento normal do concreto em relação ao aço. A utilização de elementos de mola pode ser empregada também na modelagem da aderência entre os dois materiais sem a presença de conectores.

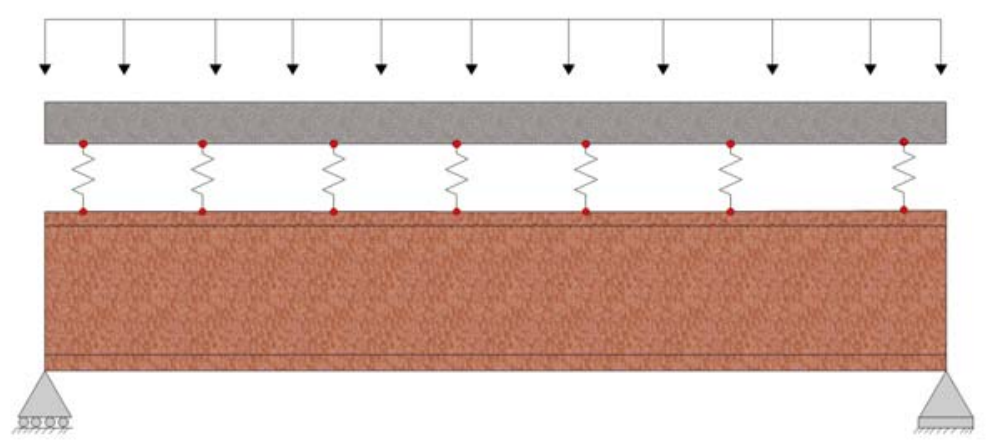

Figura 3-14 - Modelagem dos conectores por elementos de mola (SPACONE; EL-TAWIL, 2004)

Outra forma de modelar numericamente a aderência é proposta por Salari e Spacone (2001), na qual é inserida uma força tangencial distribuída ao longo da interface aço-concreto (Figura 3-15). Os modelos propostos por Salari e Spacone (2001) possuem a desvantagem de representar a aderência como um fenômeno com comportamento linear, sem incluir o efeito do amolecimento no comportamento da interface. 


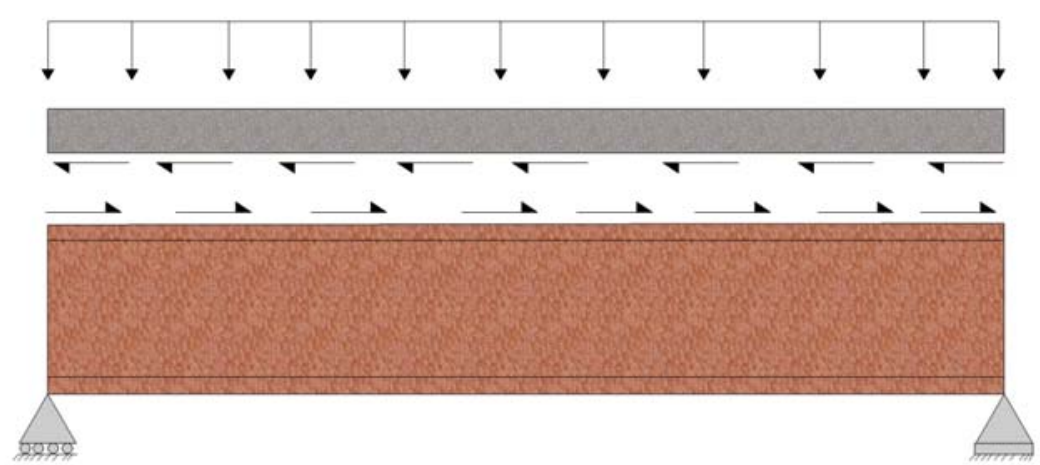

Figura 3-15 - Modelagem da aderência por carrregamento tangencial (SALARI; SPACONE, 2001)

Cabot \& Mazars (1990) afirmam que a resposta não-linear do concreto próximo à barra de aço pode ser representada por uma interface fictícia, na qual é possível especificar a lei constitutiva que governa o problema. A principal vantagem de tal procedimento é a possibilidade de incorporar na interface os diversos mecanismos presentes no problema, como o atrito. A caracterização do comportamento da interface pode ser obtida por meio de estudos experimentais, como os ensaios de arrancamento. Como alternativa, pode-se utilizar um modelo de dano que represente a danificação do concreto ao redor da armadura. Os autores ressaltam que a omissão da interface entre o aço e o concreto pode conduzir a resultados insatisfatórios.

A utilização dos elementos de interface permite implementar a aderência inicial entre os materiais e incluir o trecho descendente no comportamento da aderência, dando condições de obter resultados mais representativos. Desta forma, a modelagem com elemento de interface pode ser mais adequada que o uso de elementos de contato para análise de problemas de interface que incluem o deslizamento relativo nos dois materiais ( $\mathrm{SOH}, \mathrm{CHIEW}$ e DONG, 2002).

Segundo Soh, Chiew e Dong (1999), na literatura são encontrados dois tipos de modelos de interface: "lumped model" (Figura 3-16) e "distributed model". No primeiro, o modelo constitutivo da interface é imposto em uma interface de espessura nula. Para o 
segundo, o modelo constitutivo da interface é aplicado a uma interface de espessura definida. Para o modelo distribuído pode-se utilizar um elemento finito convencional, mas para o modelo do tipo "lumped” é necessário um elemento finito especial, definido como "elemento de interface".
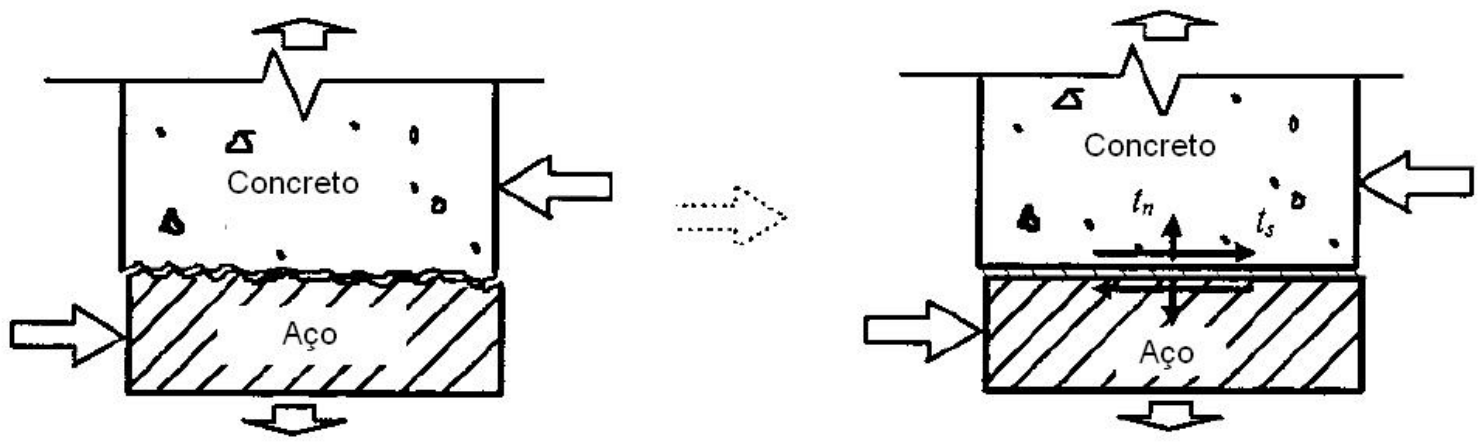

Figura 3-16 - Representação da interação Aço-Concreto pelo elemento de interface - "Lumped Model”

Sendo assim, o elemento finito de interface é um elemento finito especial desenvolvido para problemas em que seja necessário representar o comportamento da interface aço-concreto. $\mathrm{O}$ elemento finito de interface relaciona as tensões normais e cisalhantes no nó com o deslocamento relativo na direção correspondente. (Figura 3-17)

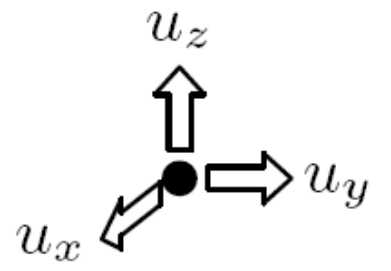

a) Deslocamentos nodais

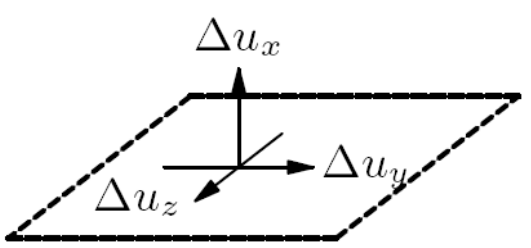

b) Deslocamentos relativos

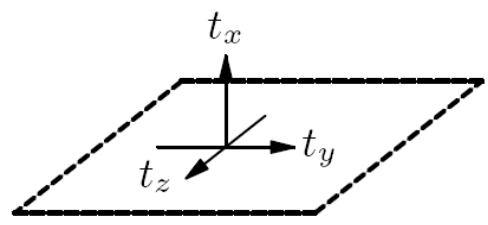

c) Tensões na interface (tractions)

Figura 3-17 - Variáveis dos elementos de interface

Para a simulação do comportamento da interface aço-concreto, a escolha dos parâmetros para calibração do modelo constitutivo da interface apresenta dificuldades, pois estes parâmetros dependem da microestrutura física dos materiais e ensaios experimentais que forneçam estes parâmetros de forma precisa são inexistentes. O modelo de comportamento da 
interface na direção normal possui uma dificuldade maior na calibração, pois a resistência à tração da interface entre aço-concreto é muito baixa e possui uma alta variação.

A lei constitutiva que relaciona a tensão cisalhante e o deslocamento tangencial pode ser encontrada em trabalhos experimentais descritos na literatura, para algumas situações. Uma das vantagens do uso do elemento de interface é a possibilidade de incluir o trecho descendente ("slip softening") na interface. Soh, Chiew e Dong (1999) propuseram um modelo que pode ser calibrado experimentalmente para diversas situações (Figura 3-18). A relação entre tensão normal e deslizamento normal é relacionada apenas pela rigidez inicial, com uma perda de rigidez linear quando é atingida a resistência máxima. Na relação com o cisalhamento é utilizada uma função cúbica que relaciona três valores de rigidez: inicial, de pico e de plastificação.

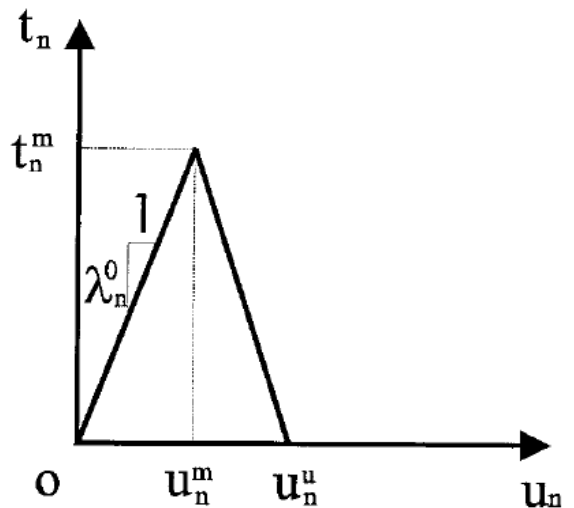

a) Relação entre deslizamento relativo normal e tensão normal na interface

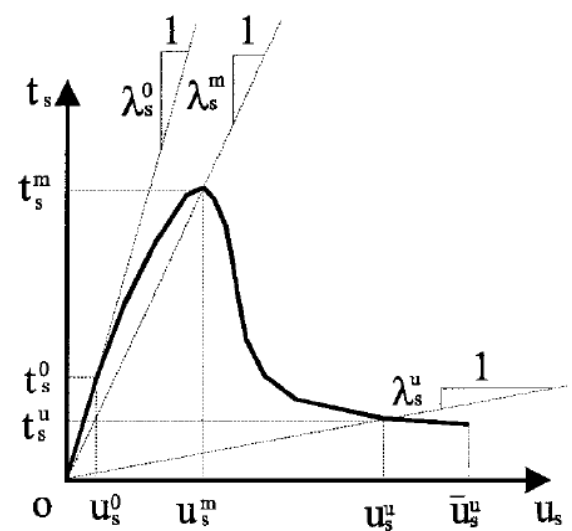

a) Relação entre deslizamento relativo tangencial e tensão tangencial na interface

Figura 3-18 - Modelo de Soh, Chiew e Dong (1999).

Hajjar, Schiler E Molodan (1998) realizaram análises via método dos elementos finitos em pilares mistos preenchidos. A rigidez da interface foi calibrada com resultados experimentais ("push-out") de diversos trabalhos experimentais. Foi utilizado um modelo bastante simplificado (bilinear), onde a calibração era feita apenas na rigidez inicial da 
interface e no deslizamento limite para a ruptura da aderência. Os resultados indicaram que o valor de 0,6 Mpa para a perda da aderência representou bem os problemas analisados.

Jeong, Kim e Ahn (2005) utilizaram o modelo de "bond-slip" associado ao método dos elementos finitos para a modelagem numérica de lajes mistas. A curva que relaciona o deslizamento relativo dos materiais e a tensão tangencial foi obtida em ensaios do tipo "pushout", nos quais modelos similares ao da laje mista foram ensaiados (espaçamento e posicionamento dos conectores). A espessura da interface era nula e o modelo foi gerado com elementos finitos sólidos, considerando carregamento estático e carregamento cíclico.

Em trabalho similar, Jeong, Kim e Kim (2005) realizaram análises numéricas para o mesmo modelo de laje mista, onde foi dada ênfase ao elemento de interface relacionado com os ensaios do tipo "push-out". Os autores afirmam que a modelagem do conector (Figura 3-19b) pode se tornar extremamente complicada, pois requer um número alto de elementos e pode gerar concentração de tensões, que podem atrapalhar a convergência. Portanto, este tipo de análise torna-se ineficiente para fins práticos. Os autores utilizaram então um modelo global, onde os conectores são substituídos por elementos de interface que simulam a interação entre os materiais (Figura 3-19c). O método utilizado pelos autores apresentou bons resultados. 


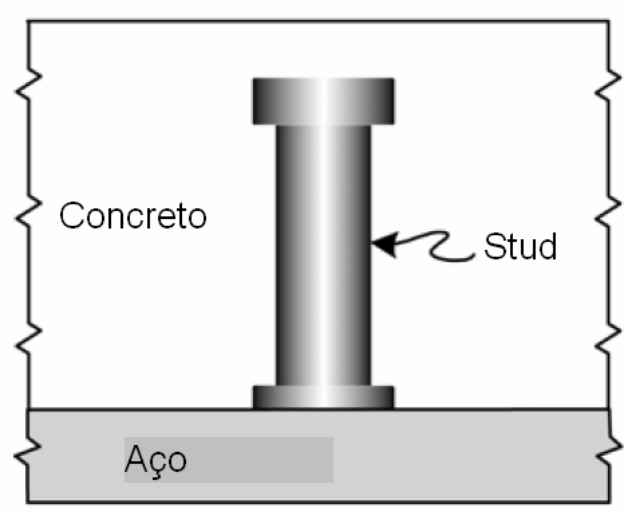

a) Modelo real

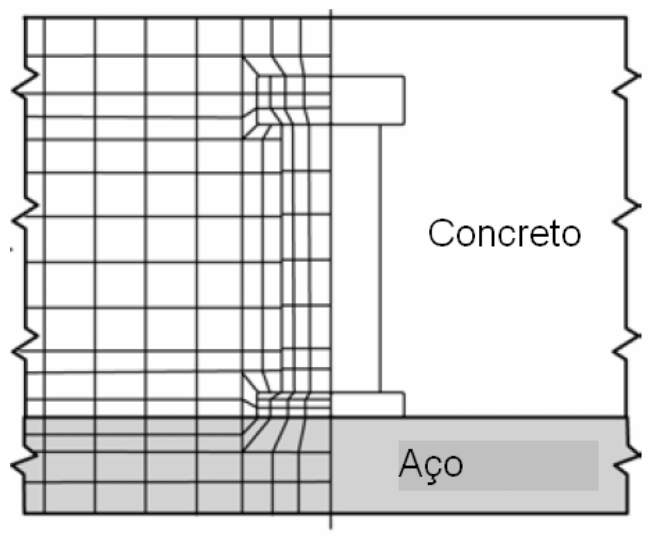

b) Modelo detalhado de elementos finitos

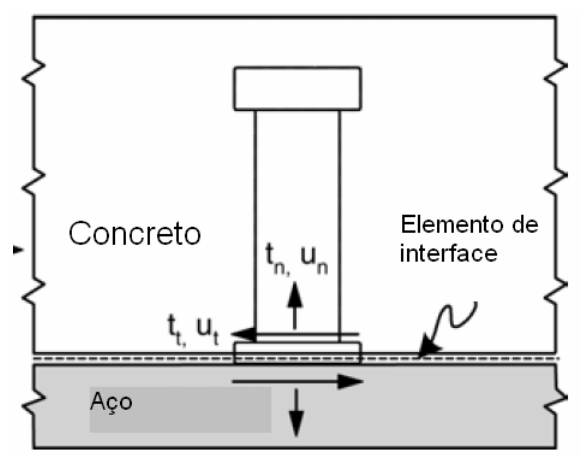

c) Modelo global com elemento de interface

Figura 3-19 - Simulação dos conectores por elemento de interface

\subsection{Considerações finais}

A aderência é uma propriedade de grande importância no comportamento estrutural dos pilares mistos preenchidos, principalmente nas regiões de ligação (região de introdução de cargas). A caracterização do comportamento da aderência através de ensaios do tipo "pushout" é a forma mais utilizada pelos pesquisadores, como nos trabalhos de Shakir-Khalil (1993a e 1993b), Parsley, Yura e Jirsa (2000) e Silva (2006). No entanto, esse tipo de caracterização não consegue representar corretamente os mecanismos de transferência de forças na região de ligação, pois tal comportamento é influenciado pela rotação da ligação. 
A aderência influencia o comportamento do pilar misto preenchido quando este é solicitado por carregamento axial, principalmente quanto à rigidez. Os trabalhos experimentais avaliam este comportamento com a redução da aderência pela aplicação de lubrificantes na interface. Apesar da contribuição da aderência nos pilares mistos preenchidos comprimidos axialmente, alguns autores comprovaram que a aderência não contribui em pilares flexo-comprimidos.

A modelagem numérica da aderência entre aço-concreto é um tema abordado em grande número de trabalhos. O uso dos elementos de interface com a implementação da curva "bond-slip" apresentou-se como a forma mais atraente para a modelagem numérica, já que alguns autores ressaltam a facilidade de convergência e de implementação. Outro aspecto importante no uso dos elementos de interface é a redução das não-linearidades no modelo numérico, quando comparado com o uso dos elementos de contato com o modelo de atrito de Coulomb. 


\section{Capítulo 4}

\section{Ligações mistas}

\subsection{Apresentação}

Neste capítulo é abordado, de forma geral, o comportamento das ligações mistas. Inicialmente, é feita uma abordagem destacando os fatores determinantes do seu comportamento e alguns estudos experimentais realizados. São apresentados também os tipos de ligações mistas e as variações de elementos presentes na mesma.

Em seguida, é destacado o comportamento das ligações mistas quanto as suas propriedades de capacidade resistente, rigidez e ductilidade. Nesta etapa, foi dada ênfase no papel da laje de concreto e a influência das armaduras no comportamento da ligação mista. Foram destacadas também algumas formulações apresentadas pelos códigos normativos (PR NBR 8800, EUROCODE 4, e ANSI/AISC 360).

Finalmente, são apresentados alguns poucos trabalhos que tratam do uso de pilares mistos preenchidos em ligações mistas.

\subsection{Aspectos gerais}

Segundo o PR - NBR 8800 (2007), uma ligação é denominada mista quando a laje de concreto participa da transmissão de momento fletor de uma viga mista para um pilar ou para outra viga mista no vão adjacente. A interação da laje de concreto com a viga metálica e a presença das armaduras da laje influem na resistência, rigidez e ductilidade da ligação. As 
ligações mistas são utilizadas em vigas mistas contínuas e semicontínuas sendo que, nas últimas, a ligação pode ser obtida a partir de uma ligação metálica flexível ou semi-rígida.

Queiroz e Pimenta (2001) afirmam que, de maneira geral as ligações mistas possuem grande rigidez inicial, mas não possuem resistência à flexão inferior à da viga suportada por ela, sendo assim classificada como uma ligação de resistência parcial. As ligações de resistência parcial devem ser projetadas de forma a garantir que a capacidade de rotação seja suficiente para que a falha ocorra nos elementos estruturais e não na ligação.

A importância da laje nas ligações envolvendo vigas mistas foi observada quando da ocorrência de abalos sísmicos, onde ligações metálicas inicialmente consideradas ligações rotuladas obtiveram acréscimo de resistência e rigidez devido à presença da laje. Estudos experimentais comprovaram que após a ruína das ligações consideradas rígidas, as ligações simples, flexíveis ou rotuladas, acrescentavam rigidez e resistência à estrutura (GREEN et al., 2004).

Vários tipos de ligações mistas podem ser encontrados na literatura, variando de acordo com o tipo de viga metálica, laje de concreto, pilar e ligação metálica. Esta diversidade gera um número expressivo de tipos de ligação, cujo comportamento é fortemente influenciado pelos seguintes parâmetros:

- Ligação metálica e seus componentes (parafusos, chapas, soldas e etc.).

- Armaduras da laje de concreto

- $\quad$ Tipo de laje (maciça, steel deck, etc.).

- Características geométricas e arranjo dos conectores de cisalhamento

- Grau de interação entre laje e viga.

- Tipo de pilar e dimensões (pilar metálico, misto, concreto e etc.). 
- Detalhamento da armadura da laje em torno do pilar.

- Tipo de carregamento: estático, dinâmico.

Apesar do grande número de variações de ligações mistas encontradas na literatura, as ligações metálicas utilizadas nestes estudos são similares. Os tipos mais comuns de ligações metálicas empregadas em ligações mistas são:

- Ligação soldada direta (Figura 4-1a).

- Ligação com chapa de alma (Figura 4-1b).

- Ligação parafusada com chapa de extremidade (comprimento parcial, total ou estendido) (Figura 4-1c).

- Ligação parafusada com cantoneira de alma e/ou cantoneira de assento (Figura 4-1d).

Os primeiros estudos a respeito das ligações mistas tiveram início nos anos 70, a partir da publicação de Barnard (1970). Posteriormente diversos estudos experimentais foram realizados. A Tabela 4-1 (SILVA; SIMÕES; CRUZ, 2001) ilustra em ordem cronológica, alguns trabalhos experimentais relevantes a respeito das ligações mistas. 


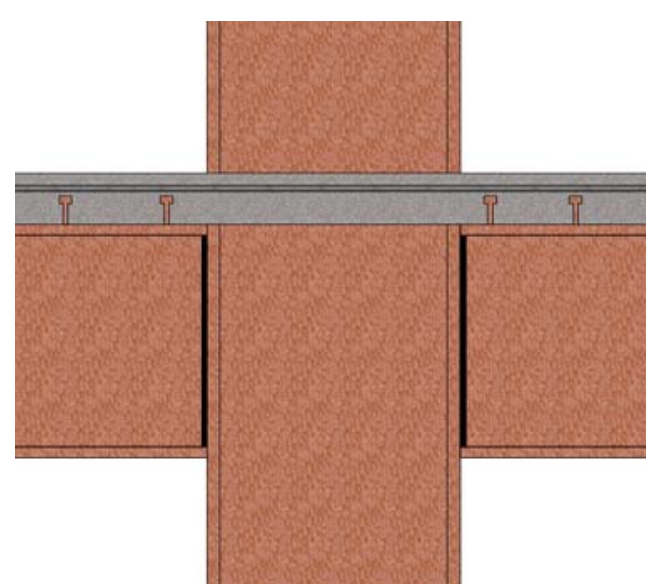

a) Ligação com soldagem da viga metálica

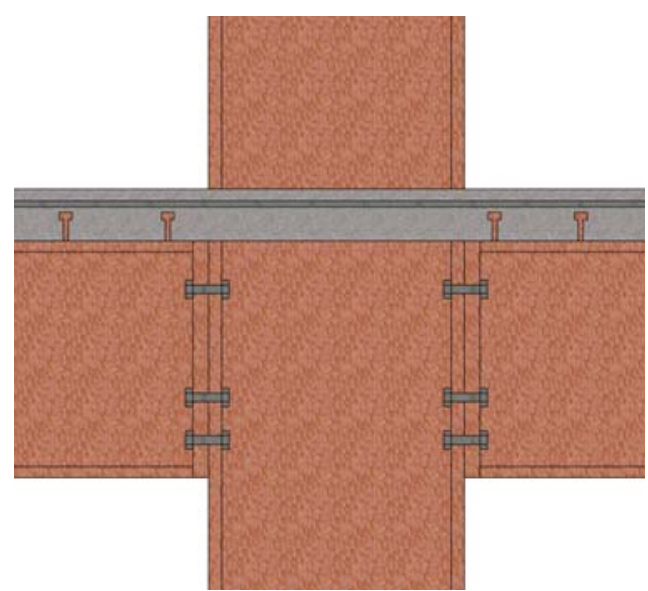

c) Ligação com chapa de extremidade

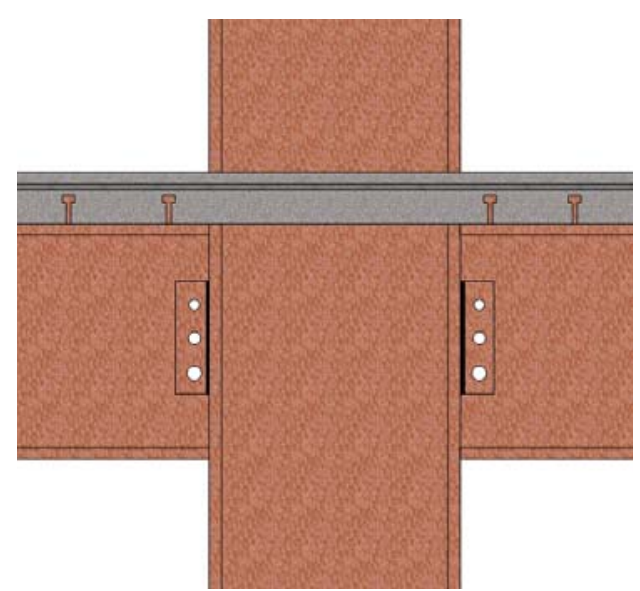

b) Ligação com chapa de alma

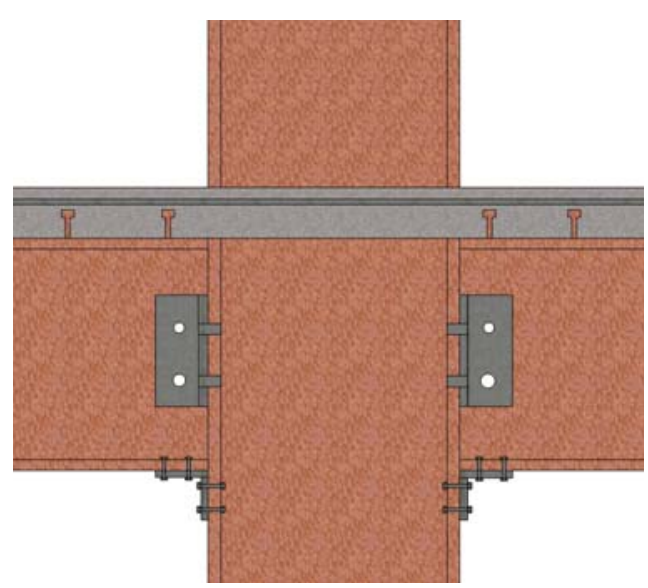

d) Ligação com cantoneiras (alma e assento)

Figura 4-1 - Ligações mistas mais usuais

O comportamento geral de uma ligação mista é caracterizado pelas seguintes propriedades:

- Resistência

- Ductilidade

- Rigidez 
Tabela 4-1 - Trabalhos experimentais a respeito das ligações mistas ao longo dos anos

\begin{tabular}{|c|c|}
\hline Autores (datas) & Detalhes \\
\hline $\begin{array}{l}\text { Johnson \& Hope- } \\
\quad \text { Gill (1972) }\end{array}$ & $\begin{array}{l}\text { Ligação mista com cantoneiras de assento parafusadas na mesa. Variação das } \\
\text { dimensões da viga de aço. }\end{array}$ \\
\hline $\begin{array}{l}\text { Owens \& Echeta } \\
\text { (1981) }\end{array}$ & $\begin{array}{l}\text { Ligação com chapa de extremidade. Variação da relação força } \\
\text { cortante/momento fletor aplicado }\end{array}$ \\
\hline $\begin{array}{l}\text { Van Dalen \& Godoy } \\
\text { (1982) }\end{array}$ & Análise do deslizamento relativo entre a laje de concreto e a viga de aço. \\
\hline $\begin{array}{l}\text { Johnson \& Law } \\
\text { (1983) }\end{array}$ & Análise dos conectores de cisalhamento e do confinamento do pilar misto. \\
\hline Benussi et al. (1986) & $\begin{array}{l}\text { Ligação com chapa de extremidade parcial e estendida. Análise da interação } \\
\text { entre a laje de concreto e o pilar. Efeito da taxa de armadura. }\end{array}$ \\
\hline $\begin{array}{l}\text { Ammerman \& Leon } \\
\text { (1986) }\end{array}$ & Estudo do comportamento das ligações com cargas cíclicas. \\
\hline Davison et al. (1990) & $\begin{array}{l}\text { Vários tipos de ligação. Influencia da orientação do pilar e do arranjo das } \\
\text { armaduras na laje de concreto }\end{array}$ \\
\hline Leon (1990) & $\begin{array}{l}\text { Comportamento de ligações com cantoneiras parafusadas, sem o efeito do } \\
\text { momento no pilar. }\end{array}$ \\
\hline Puhali et al. (1990) & $\begin{array}{l}\text { Análise da interação entre a laje de concreto e o pilar e a influência da atuação } \\
\text { de momentos não balanceados na laje }\end{array}$ \\
\hline $\begin{array}{l}\text { Altmann et al. } \\
\text { (1991) }\end{array}$ & $\begin{array}{l}\text { Estudo da rigidez entre a viga metálica e o pilar. Variação da taxa de armadura } \\
\text { na laje }\end{array}$ \\
\hline $\begin{array}{l}\text { Aribert \& Lachal } \\
\quad(1992)\end{array}$ & $\begin{array}{l}\text { Estudo de ligação com chapa de extremidade. São analisadas diversas seções } \\
\text { de viga e pilar e a interação entre a laje de concreto e a viga de aço. }\end{array}$ \\
\hline Xiao et al. (1994) & $\begin{array}{l}\text { Análise da resistência, rigidez e rotação de diferentes ligações, com variação } \\
\text { da ligação metálica e da taxa de armadura. }\end{array}$ \\
\hline $\begin{array}{l}\text { Anderson \& Najati } \\
\quad(1994)\end{array}$ & $\begin{array}{l}\text { Variação do tipo de chapa de extremidade (parcial, completa e estendida) e da } \\
\text { taxa de armadura. }\end{array}$ \\
\hline $\begin{array}{c}\text { Bode \& } \\
\text { Kronenberger (1994) }\end{array}$ & Influência da viga de aço e da laje de concreto \\
\hline Li et al. (1994) & Estudo do tipo e direção do carregamento (momento e cortante) \\
\hline
\end{tabular}

Tal caracterização pode ser representada pelo diagrama momento $x$ rotação da ligação

(NETHERCORT, 1995), no qual podem ser obtidas informações a respeito da resistência, rigidez e ductilidade da ligação, como exemplificado na Figura 4-2. 


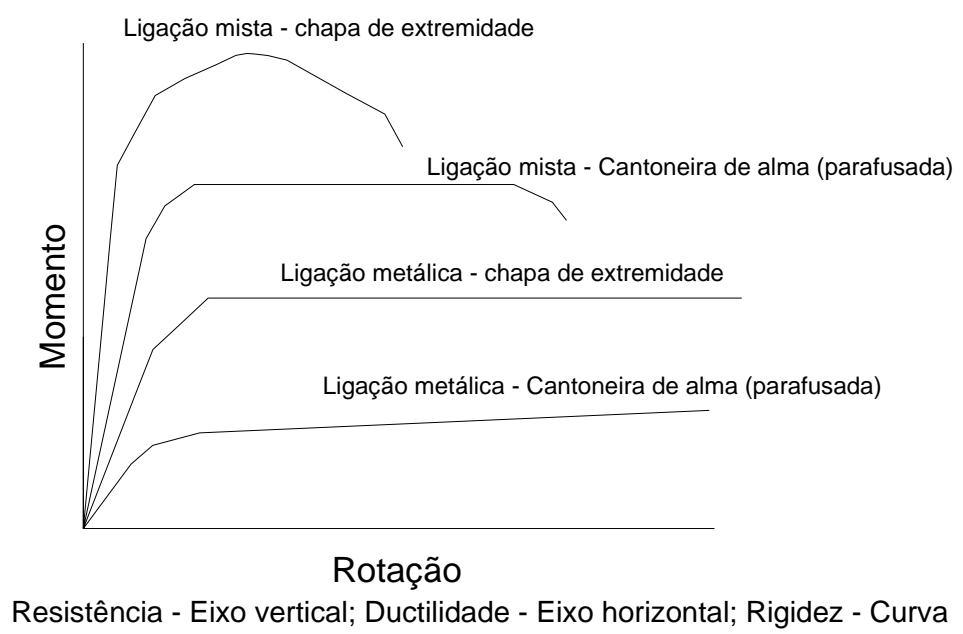

Figura 4-2 - Diagrama momento x rotação de ligação viga-pilar (exemplificação)

As ligações mistas podem ser classificadas de acordo com sua resistência, rigidez e ductilidade. A Figura 4-3 mostra esquematicamente as classificações das ligações.

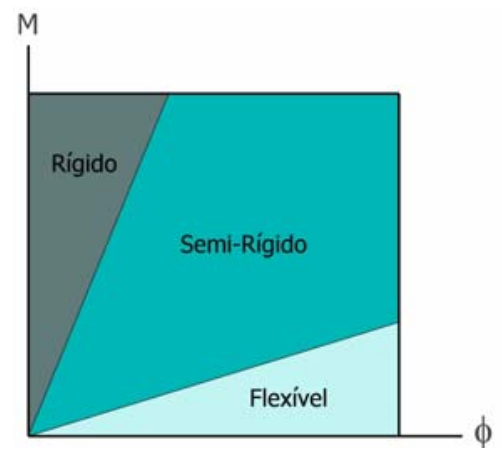

a) Classificação quanto à rigidez

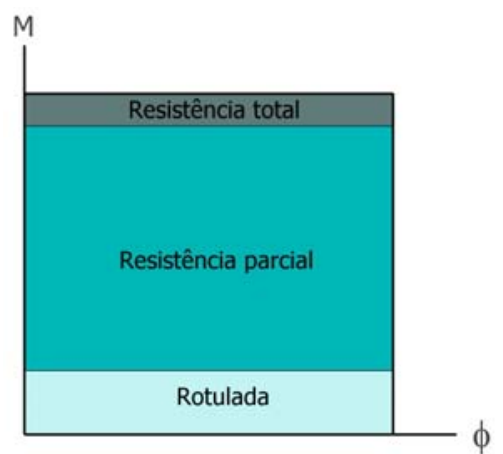

b) Classificação quanto à resistência

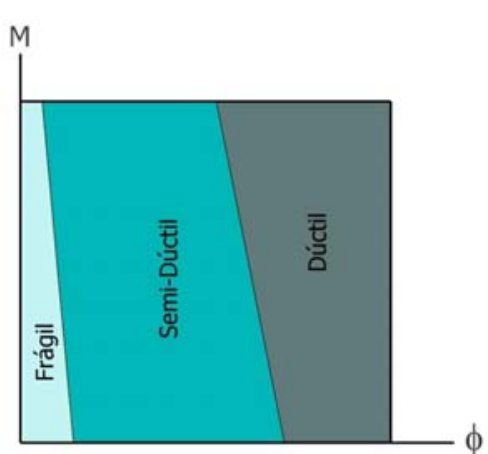

c) Classificação quanto à ductilidade

Figura 4-3 - Classificação das ligações

Quanto à rigidez, as ligações podem ser classificadas em ligações rígidas, flexíveis (rotulada) e semi-rígidas. Quanto à resistência, as ligações podem ser classificadas como:

- Resistência total: Quando a resistência da ligação é maior que a dos elementos conectados, ou seja, a ruína da estrutura ocorre por formação de rótulas plásticas nos elementos (vigas e pilares) e não na ligação.

- Resistência parcial: Quando a resistência é menor que a dos elementos conectados, resultando na formação de rotulas plásticas na ligação. 
- Rotuladas: A ligação só tem capacidade de transmitir esforços normais e cortantes.

O PR - NBR 8800 (2007) aborda apenas três tipos de ligações mistas: Ligação metálica com chapa de extremidade (altura total) parafusada na alma, mostrada na Figura 4-4a e ligação metálica com cantoneiras parafusadas na alma e mesa inferior (ligação mista vigaviga), mostrada na Figura 4-4b e Figura 4-4c. Apesar de a norma abordar apenas três tipos de ligações mistas, é permitido utilizar, alternativamente, no procedimento de cálculo, considerando a relação momento x rotação de ligações mistas pré-qualificadas, conforme a norma americana ANSI/AISC 360 (2005), mantendo, é claro, o nível de segurança exigido pela norma brasileira.

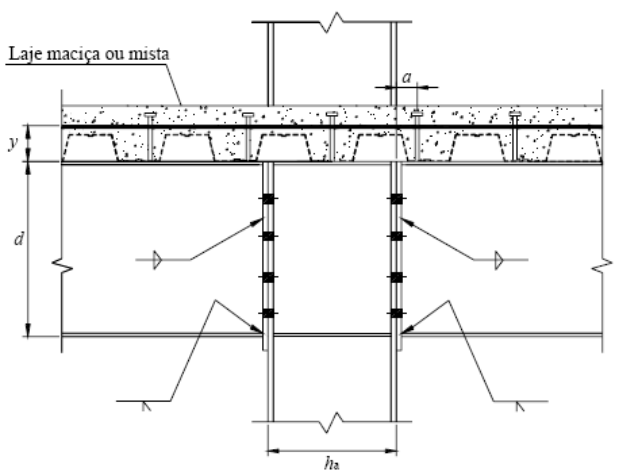

a) Ligação mista com chapa de extremidade com altura total

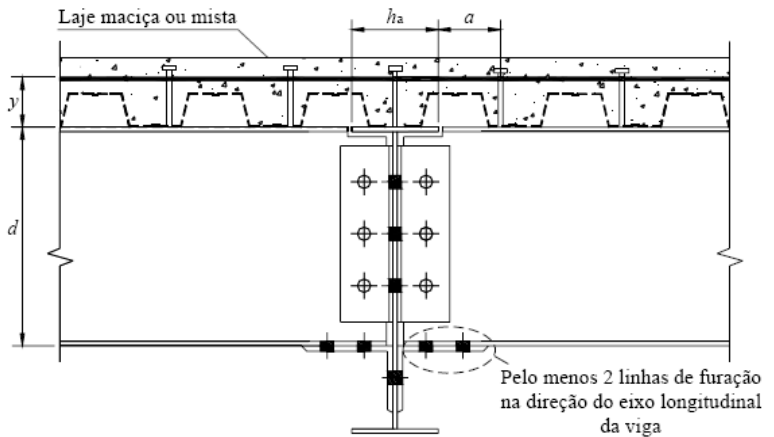

b) Ligação mista com cantoneiras parafusadas na alma (duas por viga) e na mesa inferior da viga apoiada

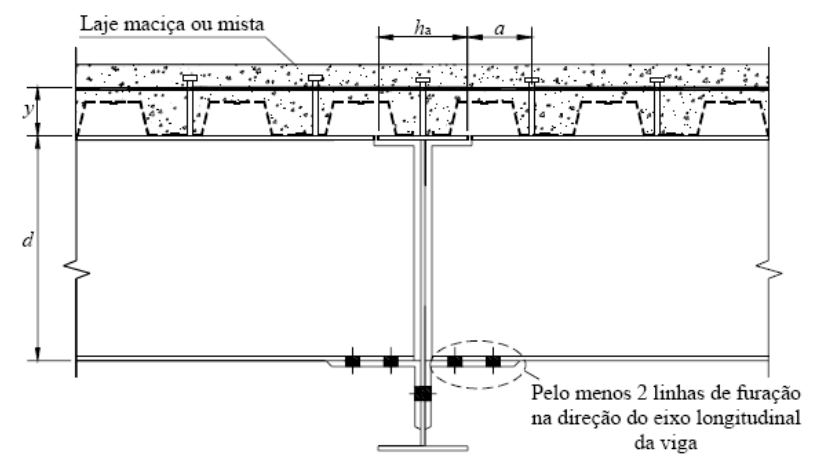

c) Ligação mista com cantoneira parafusada na mesa inferior da viga apoiada

Figura 4-4 - Ligações mistas abordadas pelo PR-NBR 8800 (2007) 


\subsection{Resistência}

A capacidade de transferência de momento fletor na ligação mista depende dos componentes da laje de concreto (as armaduras e os conectores de cisalhamento) e da ligação metálica. Segundo Nethercort (1995), a resistência da ligação mista é influenciada pela:

- Taxa de armadura da laje de concreto

- Resistência à tração dos conectores

- Resistência à compressão do pilar (flambagem local)

- Resistência à compressão da viga metálica (flambagem local)

O mecanismo de transferência de tensões em uma ligação mista é exemplificado na Figura 4-5.

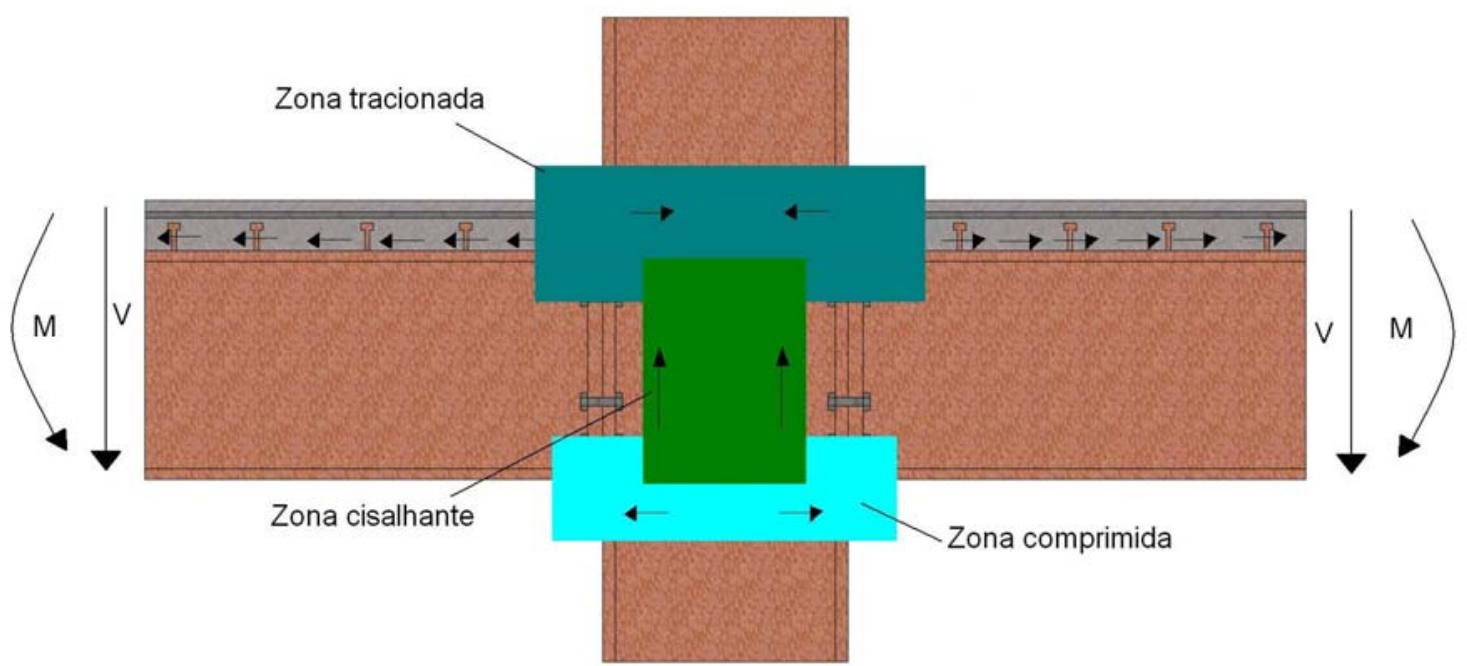

Figura 4-5 - Transferência de tensões em uma ligação mista

De acordo com o esquema apresentado na Figura 4-5, a ligação mista é solicitada por forças de tração na região superior, compressão na região superior, e cisalhamento na alma do pilar. A fim de simplificar o estudo das ligações mistas, um procedimento comum consiste na subdivisão da ligação em regiões resistentes. 
Na região tracionada os esforços de tração são resistidos pelas armaduras presentes na laje de concreto e pela parte superior da ligação de aço. Os esforços de compressão, por sua vez são resistidos pela parte inferior da ligação metálica e pelo pilar.

Contribuem para a resistência da região tracionada da ligação mista, os seguintes componentes:

- Resistência à tração da armadura de concreto

- Resistência dos conectores utilizados na viga mista.

- Resistência da ligação metálica

- Resistência ao cisalhamento entre a laje de concreto e a viga metálica.

O comportamento da laje de concreto na ligação mista pode ser dividido em 4 fases distintas, ao longo do carregamento aplicado (BERNUZZI; NOÉ; ZANDONINI, 1991).

- Comportamento elástico sem a presença de fissuras no concreto.

- Comportamento elástico com o surgimento de fissuras no concreto.

- Comportamento inelástico com perda de rigidez do concreto

- Comportamento plástico com contribuição de resistência dos conectores e da ligação metálica, ocorrendo também deformações nas armaduras da laje.

Leon (1998) afirma que a laje participa na transferência de forças e afeta a distribuição de deformações na estrutura; e por este motivo, sua incorporação e efeito devem ser considerados no dimensionamento.

O efeito da laje no comportamento das ligações mistas é controlado na verdade pelas armaduras presentes na região da ligação e pelo grau de interação da laje com a viga de aço. Bernuzzi, Noé e Zandonini (1991) afirmam que a resistência e a rigidez das ligações mistas podem ser controladas apenas com a escolha adequada da ligação de aço e o detalhamento 
correto das armaduras da laje de concreto. A incorporação das armaduras da laje de concreto ao longo do pilar acrescenta alto grau de continuidade com baixo custo.

A garantia de continuidade que as armaduras geram no elemento permite que uma ligação metálica simples atinja valores de resistência da magnitude de uma seção mista, como apresentado no estudo experimental de Puhali, Smotlak e Zandonini (1990).

O acréscimo de armadura na laje de concreto ocasiona acréscimo de resistência e rigidez na ligação. A armadura vai governar a capacidade resistente da ligação mista, até certo valor, sendo que para altas taxas de armadura o comportamento da ligação mista é determinado por outros componentes (XIAO; CHOO; NETHERCORT, 1994).

Nethercort (1995) afirma que a taxa de armadura ideal em uma ligação mista encontrase entre $0,7 \%$ e $2,0 \%$, e depende da ligação metálica e do arranjo construtivo das armaduras.

A ancoragem é outro aspecto importante no comportamento das ligações mistas. Silva, Simões e Cruz (2004) ressaltam esta importância afirmando que quando a ancoragem é executada de forma adequada se consegue garantir o bom comportamento da ligação; se realizada de forma inadequada acredita-se que a ligação mista possa trabalhar como uma ligação rotulada. Elnashai apud Silva Simões \& Cruz (2004) afirma que no mínimo 40\% da armadura deve circular o pilar na região de ligação para garantir uma boa ancoragem.

A inclusão de armaduras nas proximidades do pilar apresenta-se como uma boa alternativa para melhorar o comportamento da ligação, sendo esta armadura diminui a concentração de fissuras na laje e, consequentemente, a deformação localizada neste trecho da ligação, como foi demonstrado em estudo experimental realizado por Lam e Fu (2006). Neste estudo foi utilizada interação total entre a laje de concreto e a viga de aço e a espessura da laje foi considerada como um parâmetro fixo. Os resultados mostraram que o aumento da taxa de 
armadura, com os demais parâmetros fixados, permitiu o aumento da capacidade resistente e da capacidade de rotação da ligação.

No dimensionamento das ligações mistas, a força resistente da armadura é dada simplesmente pela tensão de escoamento das armaduras localizadas na largura efetiva da laje de concreto (Equação (4.1)).

$F_{s R d}=A_{s} f_{s d}$

$F_{\text {sRd }}$ : Força resistente da armadura na região de ligação

$A_{s}$ : Área de aço da armadura presente na largura efetiva da laje de concreto

$f_{s d}$ : Resistência de cálculo do aço

A largura efetiva da laje de concreto é definida pelas normas de acordo com o exposto na Tabela 4-2.

Tabela 4-2 - largura efetiva da laje

O valor da largura efetiva para cada lado da linha de centro da viga é tomado como o menor valor entre: ANSI/AISC 360/05 e PR - NBR 8800/2007 (para
vigas biapoiadas)

PR - NBR 8800(2007) a) $1 / 8$ do vão viga mista

b) $1 / 2$ da distancia entre o centro da viga mista e o centro da viga mista adjacente

c) A distancia entre o eixo da viga até a borda da laje. (Laje em balanço)

Para as vigas mistas contínuas e semicontínuas, admite-se, para o item a) citado anteriormente, o valor do vão sendo a distância entre os pontos de momento nulo. De forma simplificada, pode-se utilizar os seguintes valores:

- Região de momento positivo

4/5 da distância entre apoios para vão extremos e 7/10 para vão interno

- Região de momento negativo

1/4 da soma dos vão adjacentes

Para vigas em balanço admite-se o vão sendo o comprimento em balanço mais o trecho de momento negativo adjacente.

Os valores são os mesmos do item anterior, adicionando na largura efetiva a distância entre a linha de centro da viga mista com a linha de centro dos conectores de cisalhamento da viga. 
Os conectores de cisalhamento têm papel importante no comportamento das ligações mistas. O conector mais próximo do pilar na região de ligação é determinante para o comportamento da ligação mista, desde que a interação entre a laje de concreto e a viga de aço seja completa.

Fu e Lam (2006) estudaram o efeito da distância entre o primeiro conector e o pilar, concluído, no estudo experimental, concluiu que a formação de fissuras na laje depende do posicionamento deste conector, pois a primeira fissura próxima ao pilar se prolonga até este conector, independente da armadura da laje. Após o surgimento desta fissura ocorre um pequeno deslizamento entre a laje e a viga de aço neste trecho. Se o conector estiver a uma distância, significante, a fissuração na laje de concreto é muito intensa, prejudicando o desempenho da ligação. No mesmo estudo experimental, houve variação do espaçamento e do posicionamento dos conectores, mantendo o mesmo grau de interação e o posicionamento do primeiro conector. Os resultados indicaram o mesmo comportamento na ligação mista. Apesar do posicionamento dos conectores não afetarem o comportamento das ligações mistas, o grau de interação entre a viga e a laje de concreto deve interferir neste comportamento (SILVA; SIMÕES; CRUZ, 2001).

MOORE (2004) ressalta dois pontos essenciais no dimensionamento dos conectores de cisalhamento na região das ligações mistas. O primeiro é a utilização de conectores em quantidade suficiente para que a ruptura não ocorra neles, possibilitando que a falha seja governada pela redução da capacidade rotacional da ligação (escoamento das armaduras). O segundo ponto é a garantia da capacidade rotacional, por meio do posicionamento adequado do primeiro conector, que deve estar a uma distância de pelo menos 100 mm da face da pilar.

O PR - NBR 8880 (2007) preconiza que a capacidade resistente de cálculo dos conectores, na região da ligação mista, deve ser superior à das armaduras. A mesma norma 
permite, além da utilização dos conectores pino com cabeça, o uso de perfis laminados de seção "U” como conectores de cisalhamento.

A ligação de aço influencia a capacidade resistente da ligação mista, e o grande número de componentes presentes na ligação (parafusos, soldas e etc.). As ligações em aço mais usuais na literatura são as ligações com chapa de extremidade parafusada no pilar (parcial, completa ou estendida), e ligações com cantoneiras de alma e/ou de assento.

As ligações com chapa soldada na alma foram utilizadas inicialmente nos Estados Unidos e na Austrália, onde se popularizou devido à facilidade de fabricação. Este tipo de ligação em aço gera um pequeno braço de alavanca e sua capacidade de transmitir momento é baixa. Nas ligações mistas, entretanto ao considerar a presença da laje é verificado um aumento da capacidade resistente e da transferência de momento devido à introdução das armaduras da laje. As ligações com cantoneiras parafusadas na alma da viga de aço também são comuns nas estruturas metálicas convencionais. O estudo deste tipo de ligação nas ligações mistas começou a ganhar força na década de 80, com resultados de diversos trabalhos experimentais. Estes estudos indicaram que a introdução da armadura da laje nesta ligação melhorou o seu desempenho, tornando-a uma ligação de resistência parcial (AHMED; LI; NETHERCORT, 1996).

Leon (1998) afirma que ligações mistas com chapas ou cantoneiras parafusadas ou soldadas na alma da viga de aço são flexíveis e de baixa resistência. Os motivos para o baixo desempenho deste tipo de ligação são:

- Deformação dos parafusos

- Pequeno braço de alavanca entre as forças de tração e compressão na ligação

- Capacidade limitada das cantoneiras ou das chapas de ligação. 
O mesmo autor ressalta que as ligações com chapas de extremidade parafusadas apresentam desempenho superior às ligações citadas anteriormente, e que o uso de cantoneiras de assento pode ser uma maneira de melhorar o desempenho. Diversos trabalhos que abordam este tipo de ligação podem ser citados, como Silva, Simões e Cruz (2001), Ahmes e Nethercort (1996) e Xiao, Choo e Nethercort (1995).

O desempenho das ligações com chapa de extremidade tende a ser superior ao das ligações mistas com chapas e cantoneiras ligadas à alma da viga de aço. Loh e Bradford (2005) avaliam que a modelagem desse tipo de ligação (componente de aço) possui alto grau de dificuldade, já que seu comportamento é influenciado pelos diversos componentes, como a chapa de extremidade e os parafusos. E mais, a contribuição da chapa de extremidade no comportamento da ligação mista é baixa e por isto pode ser negligenciado.

O modelo de dimensionamento das ligações mistas do PR-NBR 8800 (2007) despreza o comportamento da ligação em aço na região tracionada, desde que sejam respeitados os limites apresentados. Desta forma, a verificação da ruína por ruptura dos parafusos em uma ligação mista com chapa de extremidade é desprezada. O EUROCODE 4 (2004) afirma que o dimensionamento da ligação em aço em uma ligação mista deve ser idêntico ao apresentado pelo EUROCODE 3, com a inclusão do comportamento das armaduras da laje de concreto e dos conectores de cisalhamento.

Xiao, Choo e Nethercort (1995) apresentam um método de dimensionamento para a ligação mista com chapa de extremidade. O método aborda todos os casos possíveis para o posicionamento da linha neutra e assume que, quando a linha neutra se localiza abaixo das linhas de parafusos, estes sofrem plastificação no momento da ruína da ligação. Essa hipótese foi justificada por análise experimental e numérica realizada pelos autores. De acordo com a análise experimental, a possibilidade de ruptura da ligação por ruína dos parafusos é remota. Os autores afirmam que este tipo de ruína não ocorre de forma isolada e sim associada à 
ruptura de outros elementos. Experimentalmente a ruptura dos parafusos foi observada apenas quando foram utilizados parafusos de pequeno diâmetro, chapa de extremidade de pequena espessura e baixa taxa de armadura.

A região de compressão da ligação mista é constituída apenas pela viga de aço e pela alma do pilar. A verificação desta região depende do tipo de ligação de aço utilizada. Para ligação de aço com chapa de extremidade, a verificação da resistência da mesa comprimida da viga de acordo com o PR - NBR 8800 (2007), pode ser feita pela Equação (4.2), é baseada na resistência ao esmagamento da mesa.

$F_{i R d}=\frac{M_{R d}}{d-1 / 2\left(t_{f s}+t_{f i}\right)}$

$F_{i R d}$ : Força resistente da mesa inferior da viga de aço

$M_{R d}$ : Momento fletor resistente de cálculo da viga de aço (plastificação total da seção transversal)

$d$ : Altura da seção transversal da viga

$t_{f \mathrm{~s}}:$ Espessura da mesa superior

$t_{f i}$ : Espessura da mesa inferior

Na região comprimida deve ser verificada a ruína da mesa do pilar de aço. O procedimento adotado é o mesmo para ligações em aço. A região central do pilar solicitado por cisalhamento, deve ser verificada a possibilidade de ruína por escoamento da alma do pilar.

Para pilares mistos revestidos, o EUROCODE (2004) considera o aumento da resistência devido à presença do concreto, tanto na região comprimida quanto na região cisalhada. Para pilares mistos preenchidos, o código normativo não faz menção alguma. 


\subsection{Ductilidade}

A deformação das armaduras e a fissuração da laje são fatores preponderantes no comportamento dúctil das ligações mistas, que é indicado por sua capacidade de rotação. A rotação de uma ligação pode ser caracterizada como a variação do ângulo entre a tangente do eixo da viga e o eixo do pilar, após a deformação da ligação. De uma forma simplificada, a rotação pode ser dividida em duas componentes, sendo uma a rotação na zona da ligação e outra a componente horizontal devida à deformação do pilar por cisalhamento (Figura 4-6).

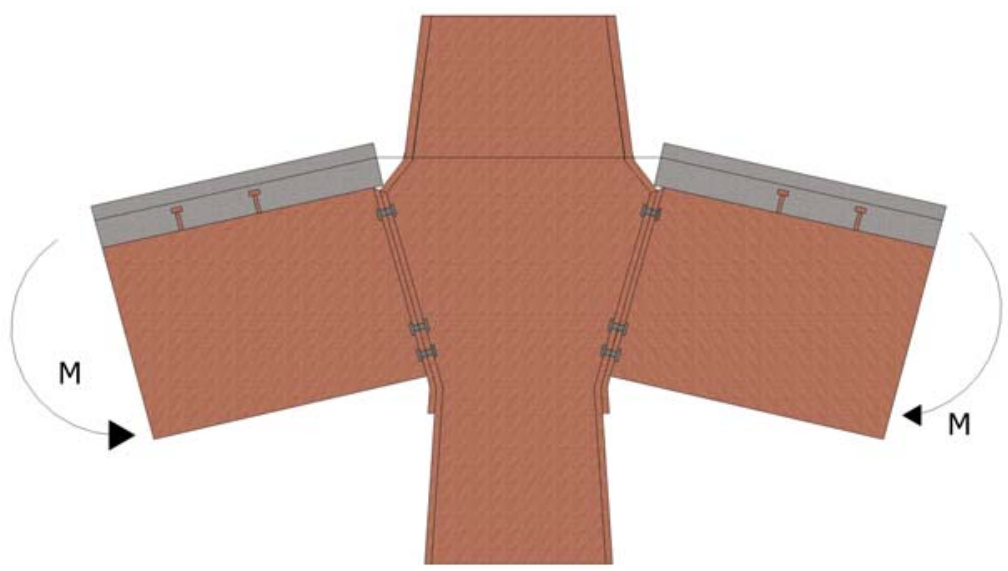

a) Rotação da zona de ligação

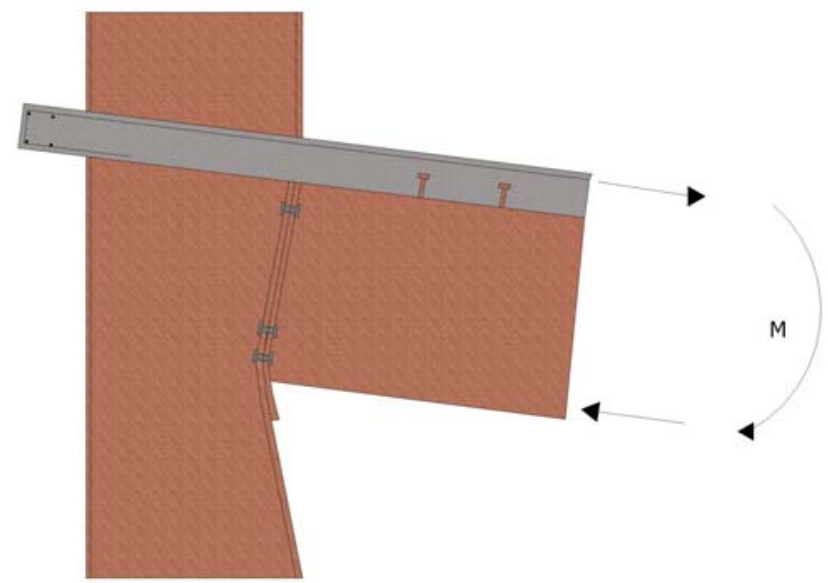

b) Rotação pela deformação da alma da coluna devido ao cisalhamento

Figura 4-6 - Componentes da rotação nas ligações mistas 
Nethercort (1995) afirma que, normalmente, a capacidade rotacional das ligações mistas é de 0,03 radianos para a formação de rótula plástica na ligação. Algumas ligações conseguem atingir valores de 0,02 radianos de rotação, sem haver perda de resistência, atingido valores de até 0,04 radianos na plastificação.

A resistência das ligações mistas é inferior ao momento resistente de plastificação da viga mista. Por este motivo, a ligação mista deve ter capacidade mínima de rotação para o desenvolvimento do momento plástico positivo na viga para que a formação de rótula plástica ocorra na viga e não na ligação.

A capacidade de rotação necessária para uma ligação mista depende da curvatura da viga, que depende de outros diversos fatores, tais como:

- A resistência da viga.

- Altura da viga de aço

- $\quad$ Rigidez da ligação e momento da viga.

- Momento solicitante (quanto menor a solicitação, menor a deformação e conseqüentemente, menor a curvatura da viga).

- Tipo de carregamento (distribuído, pontual e etc.).

- Vão da viga

Li, Nethercort e Lawson (1999) avaliaram a rotação requerida nas ligações mistas. Segundo os autores, resultados experimentais e analíticos indicam que a capacidade de rotação mínima de uma ligação mista fica em torno de 20 mRad. Quando a rotação requerida pelo projeto é menor que este valor, o resultado é satisfatório. Resultados experimentais indicam que a rotação de uma ligação mista pode chegar a valores superiores a 30 mRad, com 
taxas de armaduras de até $1 \%$. Neste estudo, os autores investigaram a capacidade de rotação requerida em ligações mistas e concluíram que:

- O uso de aço de alta resistência ocasiona um aumento da rotação requerida, pois quanto maior a resistência, maior será a capacidade de deformação para plastificação da viga (ductilidade).

- A variação das dimensões da seção da viga pouco afeta a rotação requerida quando não há variação nos demais parâmetros.

- Vigas com carregamento distribuído apresentam menor rotação requerida

A capacidade de rotação necessária da ligação mista pode ser obtida através de estudo experimental especifico. O PR - NBR 8880 (2007) apresenta valores que podem ser adotados para obter a capacidade de rotação especifica da ligação, que depende do tipo de carregamento (distribuído, pontual no centro da viga e duas cargas concentrada nos terços da viga), da resistência do aço (350 MPa ou 275 MPa), e da relação comprimento do tramo e altura da viga mista.

A capacidade de rotação das ligações mistas depende da deformação dos diversos componentes que a constituem, como:

- Deformação da armadura

- Deformação dos conectores de cisalhamento

- Deformação da região comprimida da viga de aço.

- Deslizamento relativo entre a laje de concreto e a viga de aço.

Moore (2004) apresentou resultados de ensaios experimentais de ligações mistas, com variação apenas na taxa de armadura da laje (0,6 \% e 0,2\%) e no diâmetro da armadura (8 mm e $10 \mathrm{~mm}$ ). Os resultados indicaram que os modos de ruína foram distintos com a variação de 
tais parâmetros. As armaduras com diâmetro de 10 mm apresentam capacidade de deformação menor que as armaduras de $8 \mathrm{~mm}$. Por este motivo, as ligações com mesma taxa de armadura e com variação apenas do diâmetro da barra apresentaram comportamentos de ductilidade diferenciados.

Diversos trabalhos indicam a importância do deslizamento relativo entre a laje de concreto e a viga, na capacidade rotacional da ligação. O deslizamento relativo entre a laje de concreto e a viga de aço contribui na capacidade de rotação da ligação mista (LI; NETHERCORT; CHOO, 1996). Este deslizamento depende, inicialmente, do conector de cisalhamento mais próximo do pilar, pois, ao longo do carregamento, este conector resiste sozinho ao deslizamento na região de ligação. Dificuldades são encontradas para incorporar o efeito do deslizamento no dimensionamento da ligação (ARIBERT, 1995).

Para o cálculo da capacidade da deformação da armadura da laje é assumido o diagrama tensão $x$ deformação da armadura envolvida pelo concreto (Figura 4-7). O equacionamento para o cálculo da deformação da armadura utilizado pelo PR - NBR 8800 está exposto na Tabela 4-3, e o calculo das deformações dos conectores de cisalhamento encontra-se na Tabela 4-4.

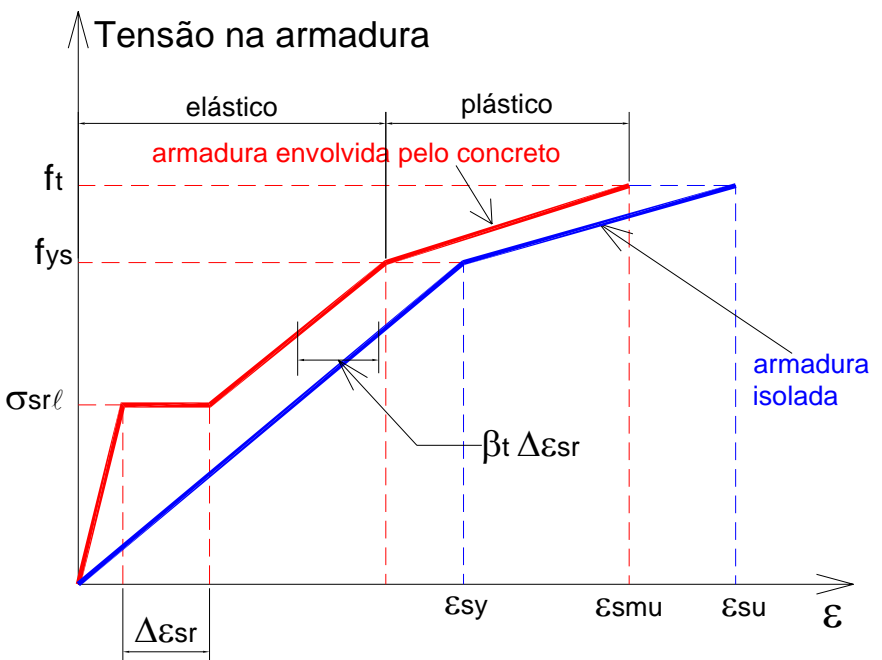

Figura 4-7 - Diagrama tensão x deformação da armadura envolvida pelo concreto 
Tabela 4-3 - Deformação das armaduras nas ligações mistas - PR-NBR 8800

\begin{tabular}{|c|c|c|}
\hline \multicolumn{3}{|c|}{$\Delta u s=L \varepsilon_{\text {smu }}$} \\
\hline$L=\frac{h_{a}}{2}+a_{c} \leq 250 \mathrm{~mm}$ & $\begin{aligned} a_{c} & \leq\left\{\begin{array}{l}a \\
L_{t}\end{array}\right. \\
L_{t} & =\frac{K_{c} \phi}{7,2 \rho}\end{aligned}$ & $K_{c}=\frac{1}{\left(1+\frac{h_{c}}{2 y_{o}}\right)} \geq 0,7$ \\
\hline$\varepsilon_{s m u}=\varepsilon_{s y}-\beta_{t} \Delta \varepsilon_{s r}+\delta_{o}\left(1-\frac{\sigma_{s r 1}}{f_{y s}}\right)\left(\varepsilon_{s u}-\varepsilon_{s y}\right)$ & $\Delta \varepsilon_{s r}=\frac{f_{c t m} K_{c}}{\rho E_{s}}$ & $\sigma_{s r l}=\frac{f_{c t m} K_{c}}{\rho}\left(1+\frac{\rho E_{s}}{E_{c}}\right)$ \\
\hline $\begin{array}{l}\text { Onde: } \\
\Delta u s \text { : Capacidade de deformação das armaduras } \\
L \text { : Comprimento de referência do concreto envolvi } \\
\varepsilon_{\text {smu }} \text { : Deformação da armadura envolvida pelo con } \\
h_{a}: \text { Largura do elemento de apoio }\end{array}$ & $\begin{array}{l}\text { pela armadura } \\
\text { eto }\end{array}$ & \\
\hline \multicolumn{3}{|c|}{$a_{c}$ : Distancia da face do elemento de apoio ao conector de cisalhamento mais próximo. } \\
\hline \multicolumn{3}{|c|}{$L_{t}:$ Comprimento de introdução de força no concreto a partir da primeira fissura } \\
\hline \multicolumn{3}{|c|}{$K_{c}$ : Coeficiente que leva em conta o equilíbrio e a distribuição de tensões na laje de concreto } \\
\hline \multicolumn{3}{|c|}{$\phi:$ Diâmetro das barras de armadura } \\
\hline \multicolumn{3}{|l|}{$\rho:$ Taxa de armadura } \\
\hline \multicolumn{3}{|l|}{$h_{c}:$ Altura da laje de concreto } \\
\hline \multicolumn{3}{|c|}{$y_{o}$ : Distância entre os centros geométricos da laje de concreto e da seção mista homogeneizada } \\
\hline \multicolumn{3}{|l|}{$\varepsilon_{\text {sy }}:$ Deformação de escoamento da armadura isolada } \\
\hline \multicolumn{3}{|l|}{$\varepsilon_{s u}:$ Deformação de ruptura da armadura isolada } \\
\hline \multicolumn{3}{|l|}{$\beta_{t}=0,4$} \\
\hline \multicolumn{3}{|l|}{$\delta_{o}=0,8$} \\
\hline \multicolumn{3}{|l|}{$f_{y s}:$ Tensão de escoamento da armadura } \\
\hline \multicolumn{3}{|l|}{$f_{c t m}:$ Resistência média do concreto à tração } \\
\hline \multicolumn{3}{|l|}{$E_{s}:$ Modulo de elasticidade do aço } \\
\hline$E_{c}:$ Modulo de elasticidade do concreto & & \\
\hline
\end{tabular}


Tabela 4-4 - Deformação dos conectores de cisalhamento (ligações mistas) - PR-NBR 8800 (2007)

$$
S^{(B)}=2 S^{(A)} \frac{F_{s}^{(B)}}{F_{s}^{(A)}} \quad \begin{gathered}
S^{(A)}=\frac{0,7 Q_{r k}}{K_{r}} \\
\cline { 2 - 2 }{ }^{(A)}=K_{c s} S^{(A)} \\
F_{s}^{(B)}=A_{s l} f_{y s}
\end{gathered}
$$

Onde:

$S^{(B)}$ : Capacidade de deformação dos conectores

$S^{(A)}$ : Deformação dos conectores no trecho elástico

$Q_{r k}:$ Resistência característica do conector

$K_{r}$ : Rigidez inicial de um conector de cisalhamento

$K_{c s}$ : Rigidez do conjunto de conectores de cisalhamento

$F_{s}^{\left({ }^{(A)}\right.}$ : Força máxima nos conectores de cisalhamento

$F_{s}^{(B)}$ : Força máxima nas armaduras

Segundo o PR-NBR 8800 (2007) a capacidade de rotação de uma ligação mista pode ser estimada pela equação (4.3), onde a cada componente da ligação mista são atribuídos os valores de deslocamentos e seus limites.

$\theta_{u}=\frac{\Delta u_{s}+\Delta_{u i}+S^{(B)}}{d+y}$

$\theta_{u}$ : Capacidade de rotação da ligação

$\Delta_{u s}$ : Deslocamento máximo da armadura (Tabela 4-3)

$S^{(B)}$ : Deslocamento máximo dos conectores

$\Delta_{u i}$ : Deslocamento do trecho inferior da ligação podendo ser adotado como $3 \mathrm{~mm}$

$y$ : Distância da mesa superior da viga de aço até a armadura da laje de concreto

$d$ : Altura da viga de aço

\subsection{Rigidez}

Para o dimensionamento das ligações mistas é necessária a caracterização da rigidez inicial da ligação. Os componentes que influenciam a rigidez da ligação mista são as armaduras, os conectores de cisalhamento e as características da ligação de aço. Segundo 
Aribert (1992), a armadura da laje pode controlar a rigidez da ligação até um valor limite, e a partir deste a rigidez ao cisalhamento passa a ter maior influência sobre a rigidez.

Uma forma de representar o comportamento de uma ligação é utilizar um método analítico, chamado de método dos componentes. O EUROCODE 3 e EUROCODE 4 (2004) permitem a utilização deste método, que consiste na subdivisão da ligação em componentes básicos, que são representados por elementos de mola. Queiroz e Pimenta (2001), afirmam que o método pode conduzir a resultados bastante satisfatórios.

Os componentes da ligação são: as armaduras, os conectores, a ligação de aço, os parafusos, etc. A representação do comportamento de cada componente é feito por curvas força $x$ deslocamento e a caracterização destes componentes pode ser obtidas por estudos experimentais ou de análises teóricas sofisticadas, como o método dos elementos finitos.

O refinamento do método consiste na inclusão de não-linearidades no comportamento dos componentes e na subdivisão da ligação em uma quantidade significativa de componentes. Huber (1999) realizou um extenso trabalho em que apresenta modelos mais refinados para método dos componentes, com a inclusão de não-linearidades.

Nas ligações mistas, ao início do carregamento leva ao desenvolvimento de fissuração na laje de concreto, causando deformações nas armaduras mais próximas ao pilar. Para uma ligação mista cruciforme, com momentos aplicados nas duas extremidades das vigas a deformação é baseada na metade da largura do elemento de apoio. O PR - NBR 8800 (2007) traz expressões para estimar a rigidez inicial das armaduras no caso de ligações mistas com momentos balanceados atuando nas duas extremidades. Já no Eurocode 4 o cálculo da rigidez das armaduras permite considerar a atuação de momentos desbalanceados. A Tabela 4-5 apresenta o cálculo da rigidez das armaduras pelos códigos normativos. 
Tabela 4-5 - Cálculo da rigidez inicial das armaduras

\begin{tabular}{|c|c|c|c|}
\hline Ligação simples & \multicolumn{2}{|c|}{ EUROCODE 4} & $k_{s}=\frac{A_{s}}{3,6 h}$ \\
\hline \multirow{3}{*}{ Ligação dupla } & $\begin{array}{l}\text { EUROCODE 4/ } \\
\text { PR - NBR } 8880\end{array}$ & $M_{E d 1}=M_{E d 2}$ & $k_{s}=\frac{A_{s}}{(h / 2)}$ \\
\hline & \multirow{2}{*}{ EUROCODE 4} & \multirow{2}{*}{$M_{E d 1}>M_{E d 2}$} & $\begin{array}{l}M_{E d 1}: \\
\qquad k_{s}=\frac{A_{s}}{h\left(\frac{1+\beta}{2}+K_{\beta}\right)}\end{array}$ \\
\hline & & & $\begin{array}{l}M_{E d 2}: \\
k_{s}=\frac{A_{s}}{h\left(\frac{1-\beta}{2}\right)}\end{array}$ \\
\hline \multicolumn{3}{|c|}{$K_{\beta}=\beta\left(4,3 \beta^{2}-8,9 \beta+7,2\right)$} & $\beta=\left|1-M_{E d 1} / M_{E d 2}\right| \leq 2$ \\
\hline \multicolumn{4}{|c|}{$\begin{array}{l}\text { Onde: } \\
M_{E d 1}: \text { Momento solicitante na ligação (lado mais solicitado) }\end{array}$} \\
\hline \multicolumn{4}{|c|}{$M_{E d 2}$ Momento solicitante na ligação (lado menos solicitado) } \\
\hline \multicolumn{4}{|c|}{$k_{s}:$ Rigidez inicial das armaduras da laje } \\
\hline \multicolumn{4}{|c|}{$A_{s}:$ Área de aço da armadura } \\
\hline \multicolumn{4}{|c|}{$\begin{array}{l}\beta \text { : Coeficiente que leva em consideração a diferença dos momentos solicitantes nos dois lados da } \\
\text { ligação }\end{array}$} \\
\hline
\end{tabular}

Aribert (1996) avaliou a importância do deslizamento entre a laje de concreto e a viga de aço na rigidez das ligações mista; neste estudo foi desenvolvido um modelo para a consideração do deslizamento entre laje-viga e para correção da rigidez dos conectores de cisalhamento devido ao deslizamento. A Tabela 4-6 apresenta os procedimentos do cálculo da rigidez dos conectores de cisalhamento adotados pelo PR-NBR 8000 (2007) e pelo EUROCODE 4 (2004). 
Tabela 4-6 - Cálculo da rigidez inicial dos conectores de cisalhamentos

$$
k_{c s}=\frac{n k_{r}}{\alpha}
$$

$$
\alpha=v-\frac{(v-1)(d+y)}{d_{s}(\xi+1)} \quad \xi=\frac{I_{a}}{d_{s}{ }^{2} A_{s l}} \quad v=\sqrt{\frac{(\xi+1) n k_{r} L_{1} d_{s}{ }^{2}}{E_{a} I_{a}}}
$$

Onde:

$k_{r}$ : Rigidez de um conector de cisalhamento $(100 \mathrm{kN} / \mathrm{mm}-120 \mathrm{kN} / \mathrm{mm})$

$n$ : número de conectores na região de momento negativo

$y$ : Distância da mesa superior da viga de aço até a armadura da laje de concreto

$d$ : Altura da viga de aço

$d_{s}$ : Distância do centróide da viga de aço ao centróide da armadura da laje

$I_{a}$ : Momento de inércia da seção transversal do perfil de aço

$E_{a}$ : Módulo de elasticidade do aço

$L_{1}$ : Comprimento da viga na região de momento negativo. Pode ser adotado 15\% do vão.

O modelo de rigidez do PR-NBR 8800 (2007) para ligações mistas leva em conta a contribuição da rigidez das armaduras, dos conectores e da parte inferior da ligação de aço. A Figura 4-8 apresenta o modelo de rigidez inicial adotado pelo PR-NBR 8880 (2007) e a equação (4.4) apresenta a formulação do PR-NBR 8800 (2007) para o cálculo da rigidez inicial de uma ligação mista.

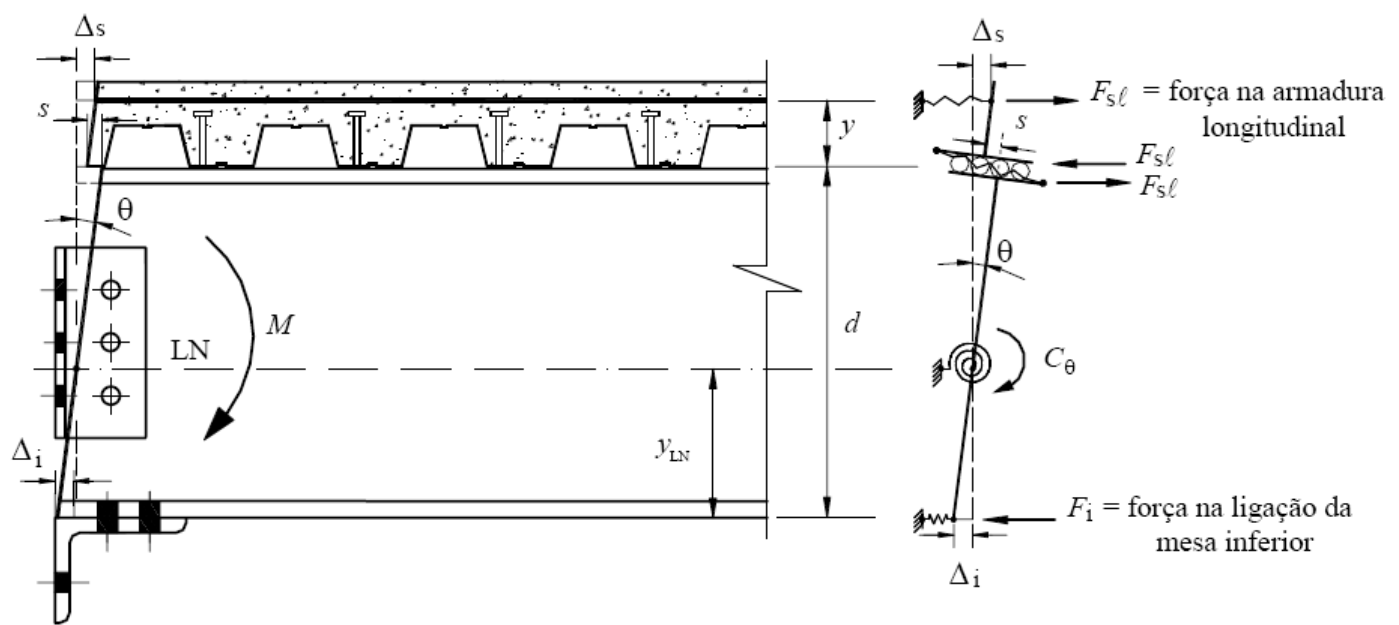

Figura 4-8 - Modelo de rigidez de ligações mistas - PR-NBR 8800 (2007) 
$C=\frac{(d+y)^{2}}{\frac{1}{k_{s}}+\frac{1}{k_{c s}}+\frac{1}{k_{i}}}$

$C$ : Rigidez inicial da ligação

$y$ : Distância da mesa superior da viga metálica à armadura da laje de concreto

$d$ : Altura da viga de aço

$k_{s}$ : Rigidez inicial das armaduras da laje

$k_{c s}$ : Rigidez inicial dos conectores de cisalhamento

$k_{i}$ : Rigidez inicial da região inferior da ligação

A rigidez inicial da ligação de aço depende dos diversos componentes que a constituem (chapas, parafusos, cantoneiras, soldas e etc.). O PR-NBR 8800 (2007) aborda apenas três tipos de ligações mistas, mas na literatura e em outras normas como o EUROCODE 3, EUROCODE 4 (2004) e AISC/ANSI 360 (2005) são encontrados procedimentos para outros tipos de ligações que podem ser adaptadas para utilização nas ligações mistas. Os valores de rigidez dos diversos componentes da ligação de aço podem ser obtidos no EUROCODE 3 para o dimensionamento das ligações mistas, desde que seja considerado o efeito das armaduras, conectores de cisalhamento, deslizamento relativo da laje e outros.

\subsection{Ligações mistas e pilares mistos preenchidos}

A maioria dos estudos experimentais com ligações mistas trata de ligações com pilares de aço com seção “H”, para os quais um dos modos de ruína está associado à compressão na alma do pilar devido à zona de compressão da ligação e por cisalhamento na alma do pilar quando os momentos não são balanceados. Em alguns estudos são inseridos enrijecedores no pilar para evitar que ocorra este último modo de falha. Em alguns trabalhos, para melhorar o desempenho do pilar de aço na região da ligação mista, são utilizados pilares mistos 
revestidos. A contribuição do concreto na resistência da região comprimida do pilar pode ser considerado no dimensionamento apresentado no EUROCODE 4 (2004), mas não há nenhuma referência nesta norma quanto aos pilares mistos preenchidos.

No caso do revestimento do perfil de aço na região de ligação, a presença do concreto não influi diretamente na resistência da ligação, mas pode contribuir para a sua rigidez e capacidade de deformação da ligação Tschemmernegg (1992).

Devido a esta contribuição, Loh, Uy e Bradford (1992), utilizaram pilares mistos preenchidos no estudo de ligações mistas, justificando o aumento da rigidez dos pilares quando comparada com seções "H” de aço. Como desvantagem, os autores afirmam que as ligações viga-pilar misto preenchido apresentam problemas de execução e exigem cuidados adicionais no detalhamento. A ligação proposta pelos autores consiste num sistema de conectores comercial, “blind boltings”, utilizados para conectar as vigas de aço ao tubo de aço do pilar. Foram ensaiados 6 diferentes modelos, com variação da taxa de armadura na laje, quantidade e posicionamento dos conectores de cisalhamento na viga mista. Para os modelos com alta taxa de armadura e conectores de cisalhamento, a falha ocorreu por flambagem local da alma da viga. Nos modelos com baixa taxa de armadura, a falha ocorreu na laje de concreto armado.

Foi observado que a deformação nas armaduras da laje não variou com a variação no número de conectores de cisalhamento e que as armaduras posicionadas mais distantes do pilar são as mais solicitadas. O benefício de se utilizarem pilares mistos preenchidos com ligações mistas foi comprovado, pois como o pilar tem grande rigidez, não ocorreu falha por flambagem local do pilar. Apesar da ocorrência de ruína por flambagem local da alma da viga, os autores afirmam que o dimensionamento correto das armaduras da laje e dos conectores pode determinar o grau de rotação e a capacidade resistente da ligação. 
De Nardin (2007) analisou experimentalmente dois tipos de ligação viga-pilar misto preenchido com a incorporação da laje de concreto, sendo um com laje maciça de concreto e outro com laje mista com fôrma incorporada. A ligação viga-pilar foi realizada com o uso de chapa passante e foi utilizado pilar misto de seção quadrada, conforme indica a Figura 4-9. Ligações similares foram estudadas sem a presença da laje com o intuito de verificar o papel da laje de concreto no comportamento da ligação.

Todos os modelos com a presença da laje apresentaram momento resistente muito superior ao das ligações viga-pilar misto. Outros aspectos relevantes são os deslocamentos e as deformações na viga. O deslocamento da viga foi mais acentuado nos modelos com a presença da laje de concreto. As deformações na viga indicaram que nas ligações mistas, a linha neutra se localiza na laje de concreto armado nos estágios iniciais de carregamento. As ligações viga-pilar apresentaram comportamento de uma ligação rotulada ou flexível, enquanto as ligações mistas apresentaram comportamento semi-rígido.

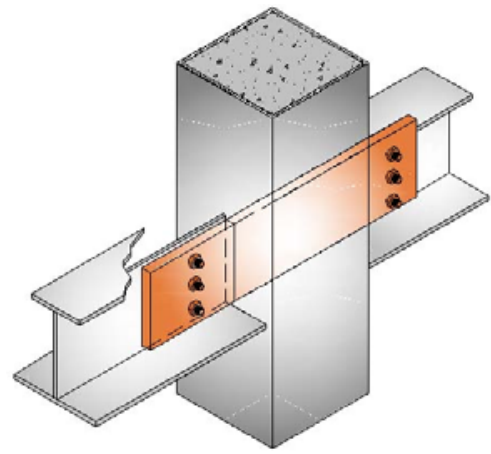

a) Ligação viga-pilar misto com chapa passante.

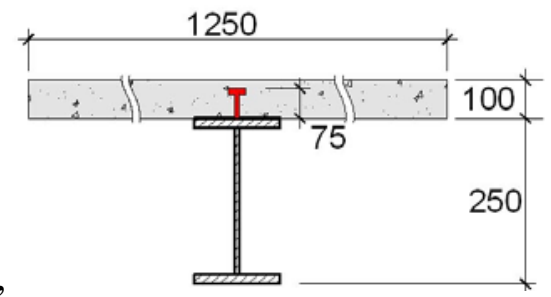

c) Modelo com laje maciça de concreto armado.

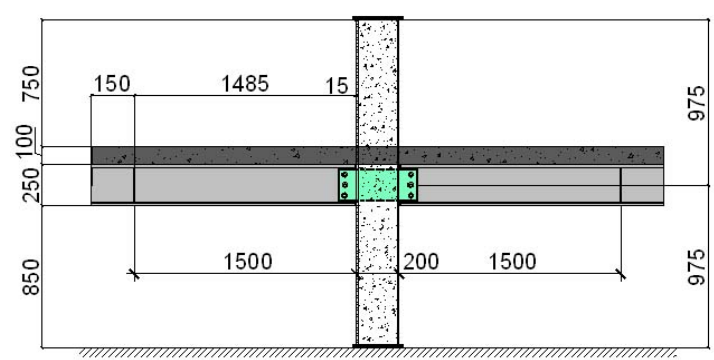

b) Modelo de ligação mista analisada (De Nardin, 2007).

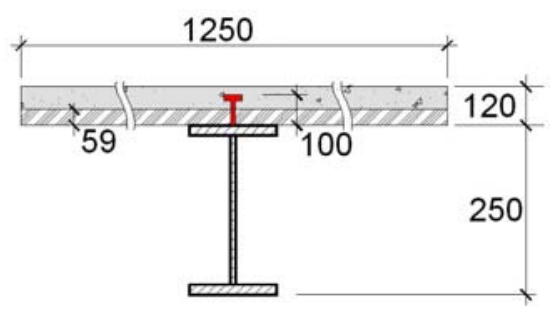

d) Modelo com laje com fôrma incorporada.

Figura 4-9 - Modelos estudados experimentalmente por De Nardin (2007) 


\subsection{Considerações finais}

A partir das análises dos inúmeros trabalhos experimentais encontrados na literatura, foi possível comprovar a influência da armadura da laje no comportamento geral (rigidez, ductilidade e resistência) das ligações mistas. Diversos parâmetros vinculados às armaduras da laje são preponderantes para o desempenho das ligações mistas, como a ancoragem, a taxa de armadura e o arranjo das armaduras nas proximidades do pilar.

Outro ponto importante no comportamento das ligações mistas é o grau de interação entre a laje de concreto e a viga de aço, e o posicionamento do primeiro conector de cisalhamento. Neste sentido a quantidade e o posicionamento dos conectores de cisalhamento não influem no comportamento da ligação, desde que o grau de interação e o posicionamento do primeiro conector permaneçam inalterados.

Os detalhes de ligação de aço utilizada nas ligações mistas apresentadas na literatura são na sua grande maioria ligações de chapa de extremidade. O PR-NBR 8800 (2007) despreza a contribuição da ligação de aço na região tracionada, e o comportamento da ligação metálica é considerado apenas na região comprimida. Alguns trabalhos encontrados na literatura apresentam formulações que consideram a resistência e a rigidez da ligação de aço na região tracionada.

O tipo de pilar utilizado não traz grande influência na resistência das ligações mistas, já que a resistência é controlada pelos diversos componentes da ligação. A inclusão do concreto no pilar adiciona rigidez à ligação mista, devido ao ganho de resistência do pilar na região de compressão e de cisalhamento. Na literatura são encontrados diversos trabalhos com o uso de pilares mistos revestidos em ligações mistas; O próprio EUROCODE (2004) fornece formulações para estimar aumento da rigidez na zona de compressão e na zona de cisalhamento para este tipo de pilar. Para pilares mistos preenchidos o mesmo não ocorre, 
sendo que nenhum dos códigos normativos analisados apresenta formulações especificas para este tipo de pilar; Na literatura técnica o assunto também é pouco abordado.

A grande maioria dos trabalhos encontrados na literatura tem caráter experimental, e poucos trabalhos apresentam propostas de modelos analíticos. Trabalhos com o uso de simulações numéricas para a modelagem do comportamento das ligações mistas são escassos, e os poucos trabalhos que realizam tal abordagem não apresentam muitos detalhes a respeito da modelagem numérica. 


\section{Capítulo 5}

\section{Análise experimental}

\subsection{Apresentação do Programa experimental}

Para a investigação experimental, a escolha da geometria e detalhes dos modelos físicos foi realizada com base em pesquisas anteriores, como DE NARDIN (2003) e SILVA (2006), de forma a dar continuidade a estes trabalhos, reforçando, adicionando e complementando conclusões a respeito do tema.

O estudo experimental foi realizado nas dependências do Laboratório de Estruturas do Departamento de Engenharia de Estruturas da EESC. As etapas do estudo experimental referentes à confecção dos perfis de aço e aos ensaios para obtenção das propriedades físicas do aço foram realizadas, respectivamente, na Oficina Mecânica do Departamento de Engenharia Mecânica e no Núcleo de Ensaios de Materiais e Análise de Falhas do Departamento de Engenharia de Materiais, Aeronáutica e Automobilística.

Para o desenvolvimento da investigação experimental foram realizadas as etapas descritas na Tabela 5-1:

Tabela 5-1 - Etapas da investigação experimental

\begin{tabular}{ll}
\hline a) & Definição dos modelos físicos \\
\hline b) & Aquisição dos materiais (vigas metálicas, parafusos, conectores, barras de aço, etc.). \\
\hline c) & Confecção dos perfis de aço, para a composição do pilar misto. \\
\hline d) & Confeç̧ão da fôrma para a moldagem da laje de concreto armado \\
\hline e) & Estudo de dosagem do concreto utilizado no núcleo do pilar preenchido e na laje \\
\hline f) & Instrumentação dos modelos \\
\hline g) & Montagem da armadura da laje de concreto armado \\
\hline h) & Moldagem do concreto da laje e do pilar misto \\
\hline i) & Caracterização dos materiais componentes \\
\hline j) & Ensaio da ligação viga-pilar misto preenchido \\
\hline h) & Análise dos resultados \\
\hline
\end{tabular}


Foram utilizados os seguintes materiais para a confecção dos modelos físicos:

- Perfis de aço tubulares de seção quadrada: obtidos a partir da soldagem de dois perfis em aço tipo SAE 1020, de seção “U” (200 x 100 x 6,3 mm) formados a frio.

- Núcleo: em concreto com 50 MPa de resistência a compressão.

- Vigas de aço de seção "I" soldadas: VS 250 x $37 \mathrm{~kg} / \mathrm{m}$, confeccionadas em aço ASTM A36.

- Laje de concreto armado (124 cm x $30 \mathrm{~cm}$ x $10 \mathrm{~cm})$, confeccionada em concreto C50 e barras de armadura em aço CA-50.

- Conectores de cisalhamento: tipo pino com cabeça com diâmetro de 19 mm ou perfis cantoneira L50x6,3 mm, confeccionados em aço SAE 1020), soldados no interior do perfil de aço do pilar misto.

- Ligação viga-pilar: com chapa de extremidade e barras rosqueadas que atravessam o pilar preenchido.

- Barras rosqueadas de alta resistência: utilizadas como longos parafusos para fazer a ligação entre a viga mista e o pilar preenchido.

Os modelos ensaiados representam detalhes cruciformes de ligação viga-pilar, nos quais a ligação é constituída por chapas de extremidade e parafusos passantes (barras rosqueadas) unindo, assim, as vigas de aço ao pilar misto. A seção transversal dos pilares foi mantida a mesma utilizada nos estudos de DE NARDIN (2003) e SILVA (2006). O detalhe de ligação viga-pilar é idêntico à utilizada em SILVA (2006), diferenciada pela inclusão da laje de concreto armado.

Ao todo, a investigação experimental é composta por três modelos de ligação vigapilar misto preenchido que se diferenciam apenas pela ausência ou presença de conectores de 
cisalhamento no interior dos perfis de aço. A Figura 5-1 mostra as dimensões, detalhes, e nomenclatura utilizados nos três modelos físicos ensaiados.
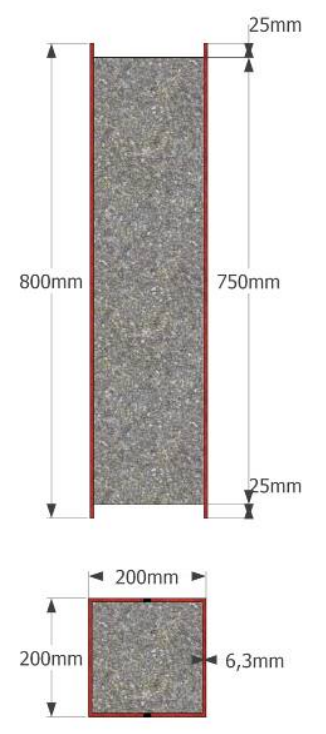

a) Modelo sem conectores CC_W - (Composite connection - Without) -
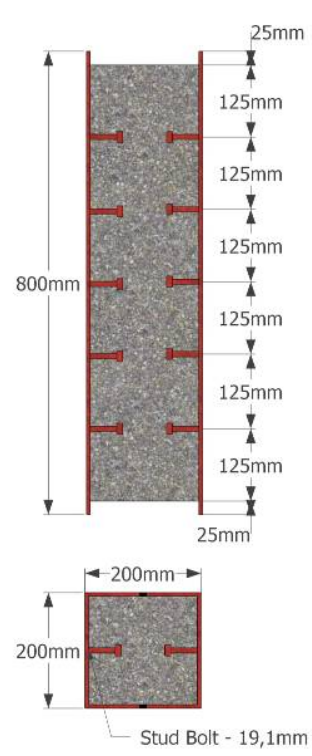

b) Conectores de cisalhamento tipo pino com cabeça (“stud bolt”) - CC_SB (Composite connection - Stud Bolt)
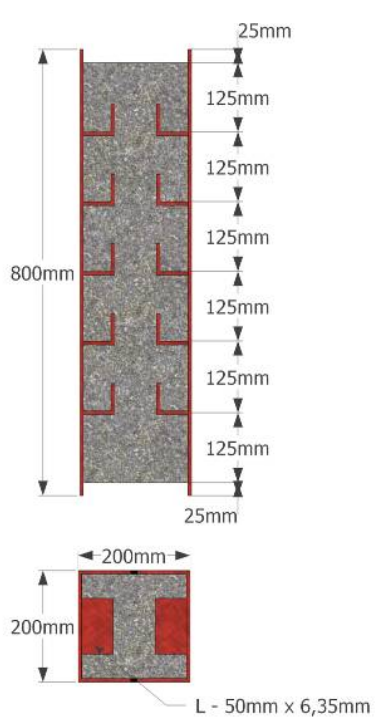

c) Cantoneiras metálicas - Modelo CC_AN (Composite connection - Angle)

Figura 5-1 - Dimensões e detalhes do pilar misto estudado.

Devido à presença e participação da laje de concreto armado na transferência de momento fletor da viga mista para o pilar preenchido, este tipo de ligação pode ser considerado uma ligação mista. Os detalhes da viga de aço estão expostos na Figura 5-2 e os detalhes geométricos da ligação e da montagem do modelo são mostrados na Figura 5-3. 


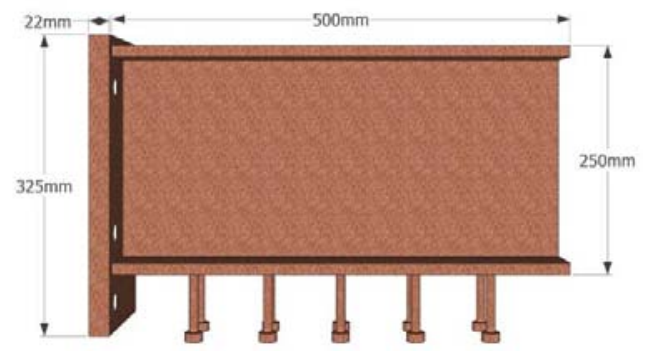

a) Dimensões da viga de aço

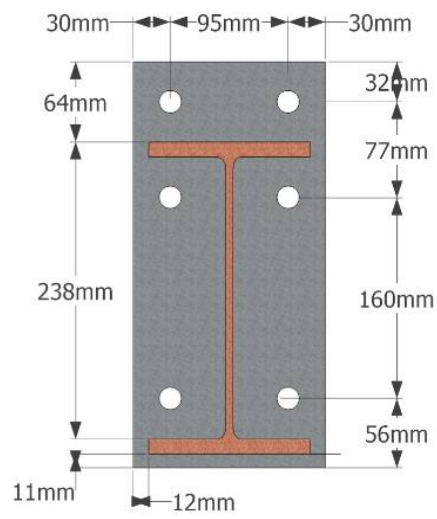

b) Detalhes da chapa de extremidade utilizada na ligação

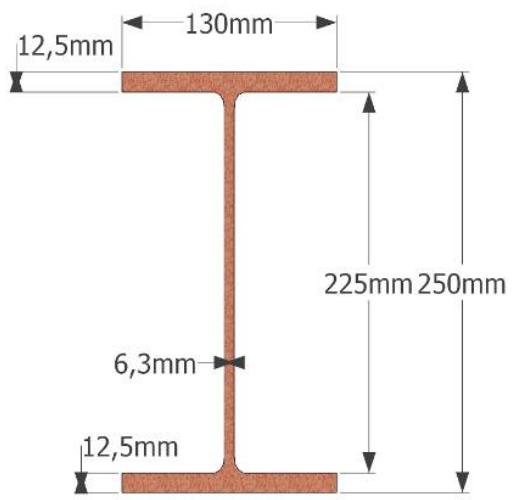

c) Seção da viga de aço VS 250 x $37 \mathrm{~kg} / \mathrm{m}$

Figura 5-2 - Detalhes da viga de aço utilizada na ligação.

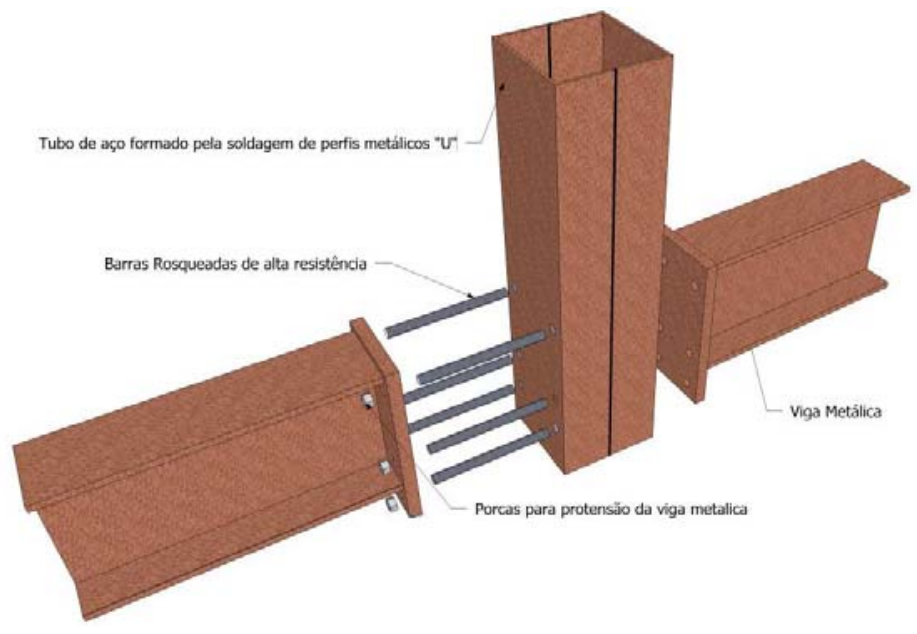

a) Esquema de montagem

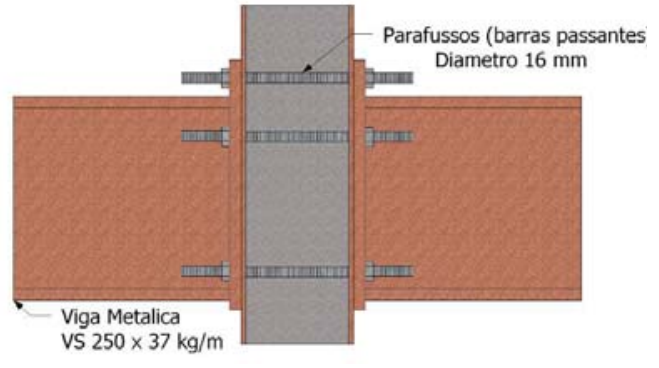

b) Detalhes da ligação

Figura 5-3 - Detalhes da ligação viga-pilar misto.

A laje de concreto possui uma taxa de armadura em torno de $1 \%$, dimensões de $124,5 \mathrm{~cm}$ x $30 \mathrm{~cm}$ e espessura de $10 \mathrm{~cm}$. Foi adotado cobrimento de $2 \mathrm{~cm}$ na armadura da laje. 
A Figura 5-4 mostra as dimensões da laje de concreto armado e a disposição das armaduras positivas e negativas. Perpendicularmente à viga, foi utilizada uma armadura de distribuição.

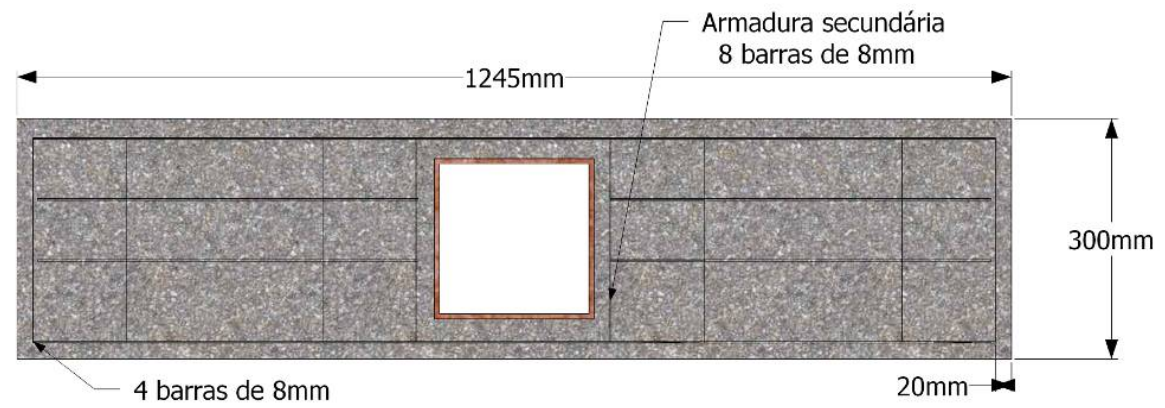

a) Armadura positiva

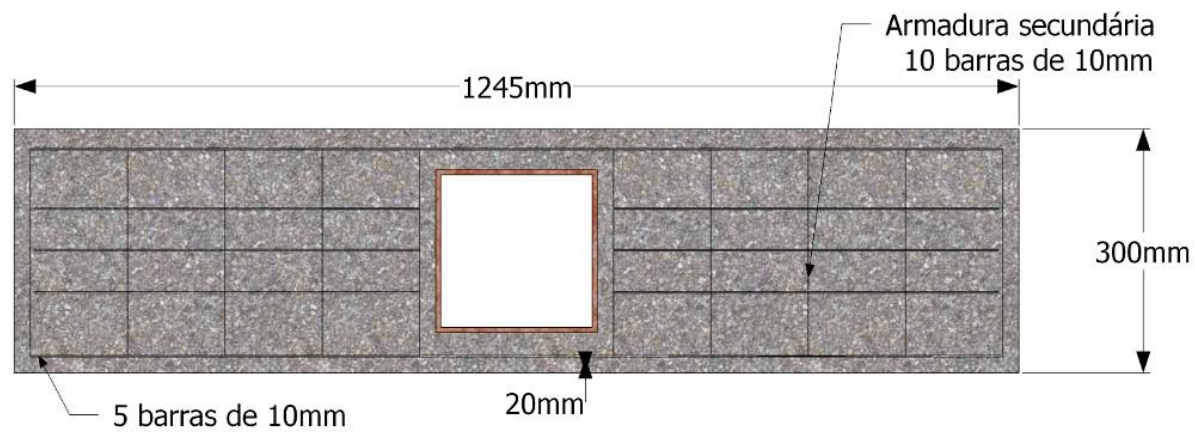

b) Armadura Negativa

Figura 5-4 - Detalhes da laje de concreto armado

Em cada um dos modelos de ligação foi aplicada uma força de compressão no núcleo de concreto do pilar preenchido e a ligação mista, apoiada diretamente em vigas de aço bastante robustas, a uma distância de $40 \mathrm{~cm}$ da face do pilar, recebia as forças de reação. Desta forma, com a aplicação da força na seção de concreto, foi possível analisar a transferência de esforços de cisalhamento entre o concreto e o aço, tanto no pilar misto quanto na região de ligação. Com este esquema de ensaio tornou-se possível analisar a contribuição de cada um dos mecanismos de transferência de forças (adesão química, aderência mecânica e atrito) entre os materiais e a contribuição dos conectores de cisalhamento (tipo pino com 
cabeça e cantoneiras) no comportamento da ligação. A Figura 5-5 mostra o esquema de ensaio.

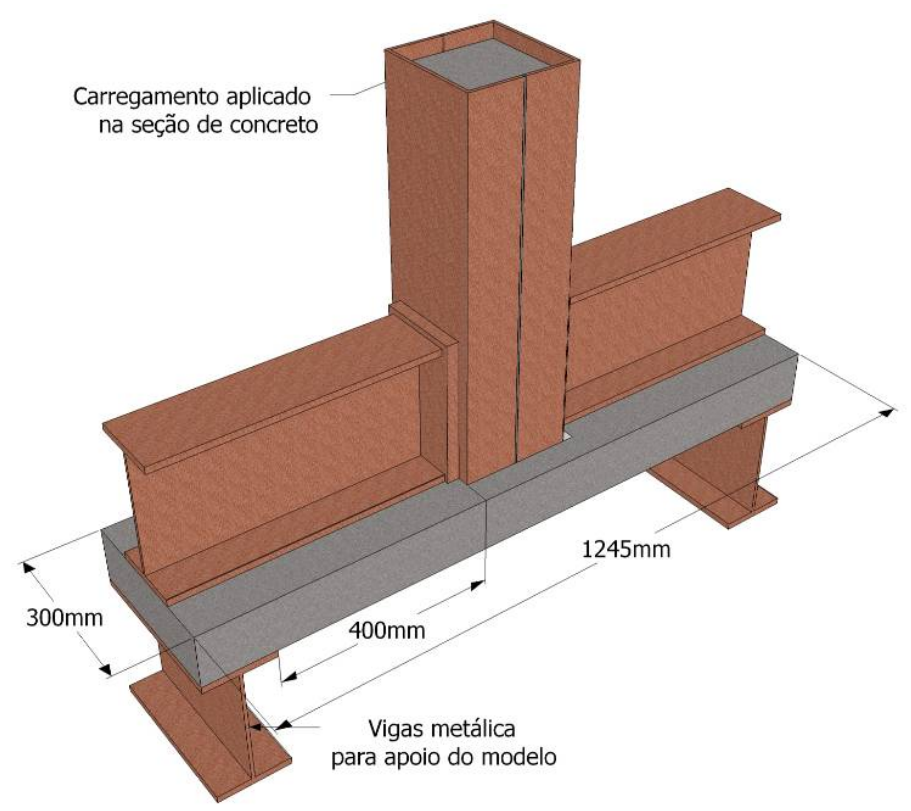

Figura 5-5 - Esquema de ensaio.

Como o modelo estudado é idêntico àquele analisado experimentalmente por SILVA (2006), diferenciando-se do mesmo apenas pela inclusão da laje de concreto armado, os resultados obtidos possibilitarão analisar a contribuição da laje de concreto no comportamento deste detalhe de ligação.

\subsection{Materiais Componentes}

\subsubsection{Aço}

Os perfis de aço formados a frio que compõem o pilar misto foram obtidos a partir da soldagem de perfis de seção "U”. O aço tipo SAE 1020 foi utilizado para a confecção dos perfis que foram solados formando uma seção quadrada com $200 \mathrm{~mm}$ de lado e 6,3 $\mathrm{mm}$ de espessura. 
Uma vez cortados os perfis "U” no comprimento de $80 \mathrm{~cm}$ e feita a soldagem dos conectores de cisalhamento, o fechamento do tubo foi realizado a partir da soldagem dos perfis. A Figura 5-6 mostra algumas etapas da confecção dos perfis de aço que compõem o pilar misto de seção quadrada.

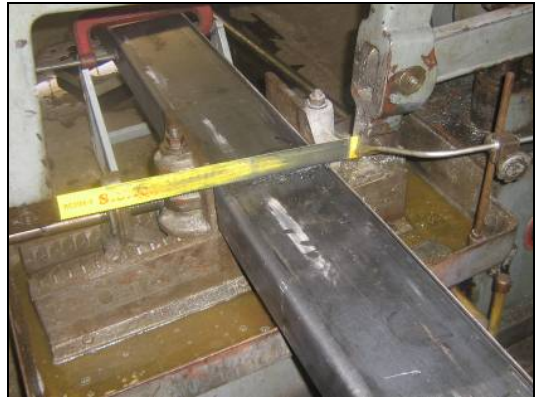

a) Corte dos perfis de seção “U”

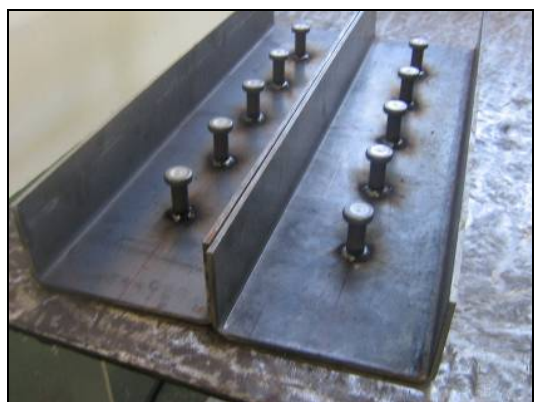

c) Perfil "U" com conector tipo pino com cabeça

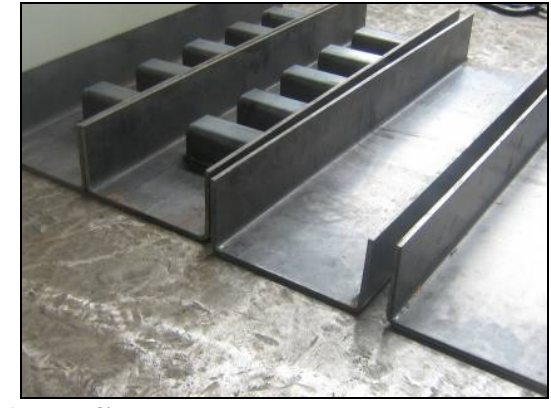

b) Perfis cortados com conectores já soldados nas faces.

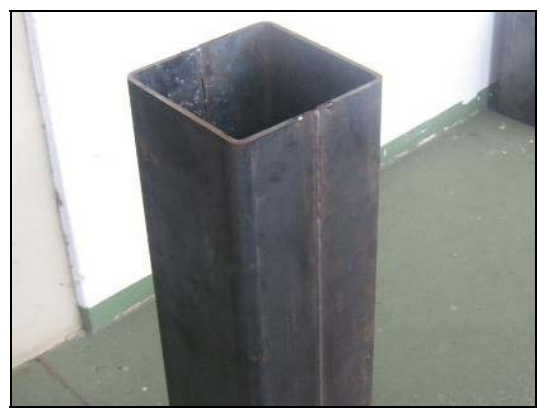

d) Perfil de aço: seção final

Figura 5-6 - Montagem do tubo de aço para o pilar misto.

As vigas de aço foram confeccionadas a partir da soldagem de chapas em aço ASTM A36. Foram soldados conectores de cisalhamento tipo pino com cabeça na mesa superior da viga em número tal que resultasse em uma viga mista com interação total.

Tanto dos perfis que compõem o pilar misto como das vigas de aço foram extraídos corpos de prova para determinar as propriedades mecânicas do aço (resistência ao escoamento, resistência à ruptura e módulo de elasticidade). Estas propriedades foram obtidas via ensaios de tração axial, especificados pela ASTM 370:1992. Os corpos-de-prova empregados na caracterização possuíam as dimensões mostradas na Figura 5-7. 


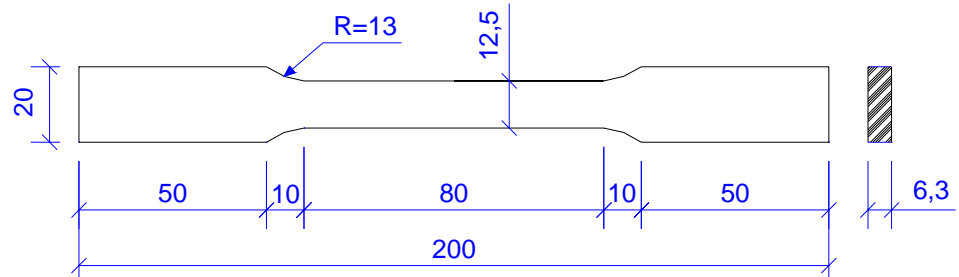

Figura 5-7 - Dimensões dos corpos de prova para caracterização do aço.

Foram retirados corpos-de-prova de todas as faces do perfil de aço, inclusive da face com solda. Para a viga de aço foram retirados corpos-de-prova das mesas e alma, e da chapa de extremidade utilizada na ligação viga-pilar. A Figura 5-8 mostra a realização do ensaio de tração uniaxial dos corpos de provas de aço. Para cada elemento foram ensaiados três corposde-prova. A Tabela 5-2 traz as propriedades mecânicas do aço, obtidas com o ensaio de tração uniaxial, os resultados expostos são valores médios dos três ensaios. Alguns resultados do comportamento tensão $x$ deformação dos corpos-de-prova de aço ensaiados são mostrados na

\section{Erro! Fonte de referência não encontrada..}
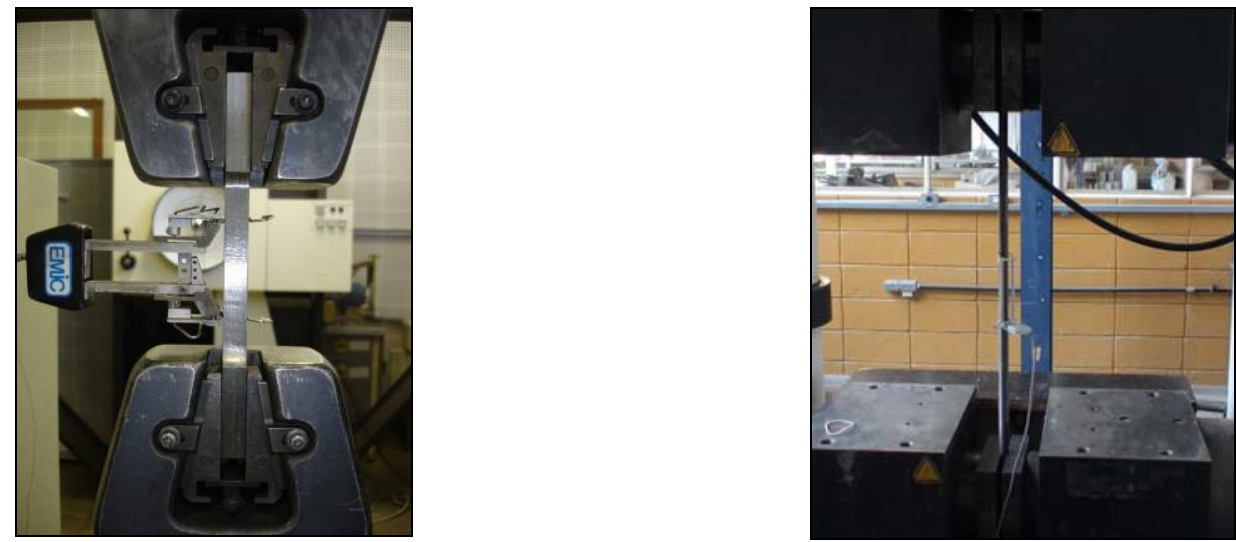

Figura 5-8 - Ensaio de tração uniaxial para caracterização mecânica do aço. 
Tabela 5-2 - Propriedades mecânicas do aço.

\begin{tabular}{cccc}
\hline Corpos-de-prova & Aço & $\begin{array}{c}\text { Resistência ao escoamento } \\
(\mathrm{MPa})\end{array}$ & $\begin{array}{c}\text { Resistência à Ruptura } \\
(\mathrm{MPa})\end{array}$ \\
\hline Perfil - Pilar & SAE 1020 & 216,5 & 349,5 \\
\hline Viga - Mesa & ASTM & 313,7 & 452,7 \\
& A36 & & 414,9 \\
\hline Viga - Alma & ASTM & 274,7 & 423,8 \\
& A36 & & \\
\hline Chapa de & ASTM & 327,2 & 608,6 \\
\hline extremidade & A36 & & \\
\hline Parafusos & ASTM & 510,8 & \\
\hline
\end{tabular}

\subsubsection{Concreto}

O concreto utilizado na investigação experimental, tanto para o preenchimento do perfil de aço do pilar quanto na laje de concreto armado, possuía resistência média à compressão de 50MPa.

Foram utilizados os seguintes materiais para a confecção do concreto:

- Cimento: CP-V ARI, cimento Portland com alta resistência inicial da marca Holcim fabricado pela Ciminas.

- Agregado Graúdo: Agregado de origem basáltica, da pedreira Morada do Sol, Araraquara - SP.

- Agregado Miúdo: Areia quartzosa.

- Sílica Ativa: Silmix fabricad

- a pela Camargo Correia.

A proporção em massa, utilizada na dosagem do concreto foi de 1: 1,5: 2,7 (cimento, areia e brita) com relação água/cimento de 0,55. Foi realizada a adição de 5\% de sílica ativa, em relação à massa de cimento. 
Foram determinadas algumas propriedades mecânicas do concreto, tais como, resistência à compressão, resistência à tração, módulo de elasticidade e energia de fraturamento. A resistência à compressão, módulo de elasticidade e resistência à tração foram obtidos por meio de ensaios mecânicos em corpos de prova cilíndricos de $10 \mathrm{~cm} \mathrm{x} 20 \mathrm{~cm}$. A resistência à tração foi obtida com ensaios de tração por compressão diametral. A Figura 5-9 mostra a realização dos ensaios de resistência à compressão, módulo de elasticidade e resistência à tração.

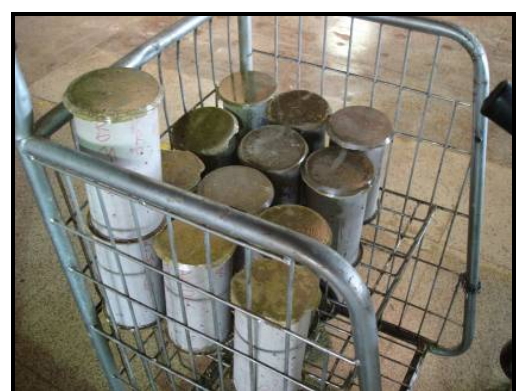

a) Corpos-de-prova $(10 \mathrm{~cm} \times 20 \mathrm{~cm})$

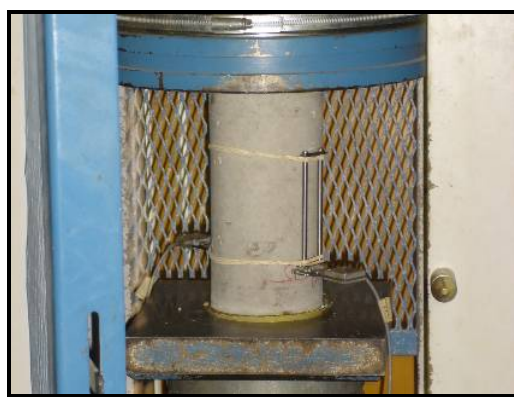

c) Realização do ensaio de resistência à compressão e módulo de elasticidade

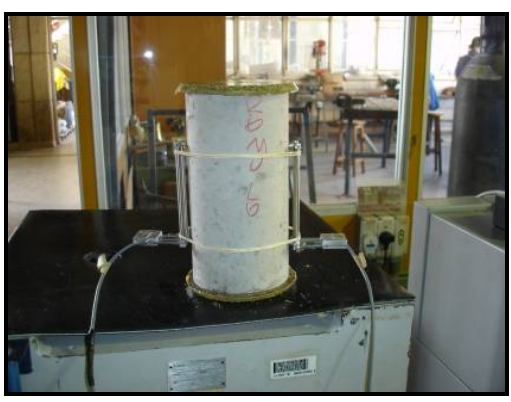

b) Instrumentação para determinação do modulo de elasticidade

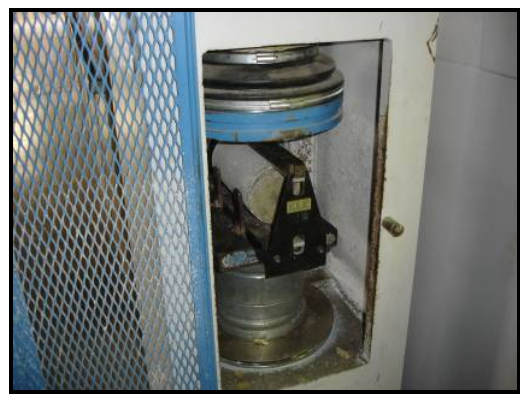

d) Ensaio de tração por compressão diametral

Figura 5-9 - Ensaios para caracterização mecânica do concreto.

Foram moldadas vigas prismáticas com as dimensões de $15 \mathrm{~cm}$ x $15 \mathrm{~cm}$ x $50 \mathrm{~cm}$, para a realização do ensaio para a obtenção da energia do fraturamento do concreto. A quantificação experimental da energia de fraturamento é realizada de acordo com os procedimentos da RILEM (Comitê Técnico n. 50, 1990), ensaio este baseado no modelo da fissura fictícia de HILLERBORG (1976). A partir deste ensaio é possível obter também o 
módulo de elasticidade e a resistência à tração do concreto. A Figura 5-10 mostra a realização do ensaio de energia de fraturamento e a Tabela 5-3 reúne os valores médios obtidos nos ensaios de caracterização do concreto.

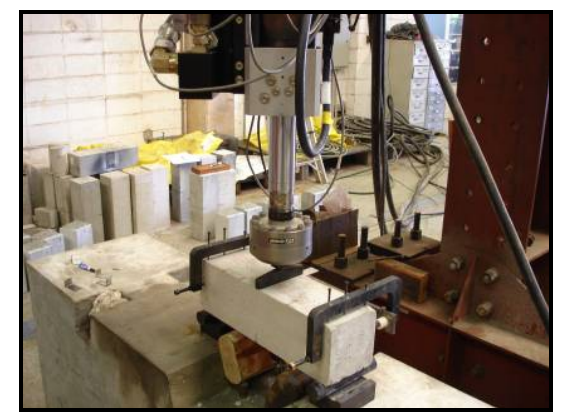

a) Realização do ensaio para determinação da energia de fraturamento.

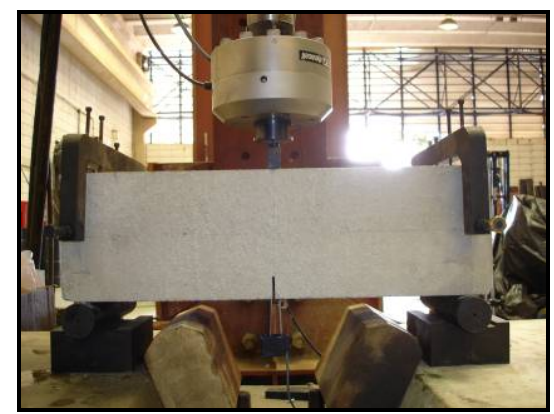

b) Ensaio de energia de fraturamento.

Figura 5-10 - Ensaio para a obtenção da energia de fraturamento do concreto.

Tabela 5-3 - Propriedades Mecânicas do concreto.

\begin{tabular}{cc}
\hline Resistência média à compressão (MPa) & 51,3 \\
\hline Resistência média à tração (MPa) & 3,7 \\
\hline Módulo de Elasticidade (MPa) & 45699 \\
\hline Energia de fraturamento (N/m) & 96,23 \\
\hline
\end{tabular}

\subsection{Instrumentação}

Os modelos físicos foram instrumentados com extensômetros elétricos para o registro das deformações em diversos pontos do modelo. Externamente, no perfil de aço foram posicionados 12 extensômetros ao longo do comprimento do pilar. Os extensômetros foram dispostos nas faces que receberam os conectores, externamente, entre os conectores, permitindo observar a transferência de forças entre o concreto e o aço ao longo do comprimento do pilar. Com esta instrumentação também foi possível avaliar a contribuição dos conectores de cisalhamento para a transferência de forças. A Figura 5-11 indica o posicionamento dos extensômetros no tubo de aço. 

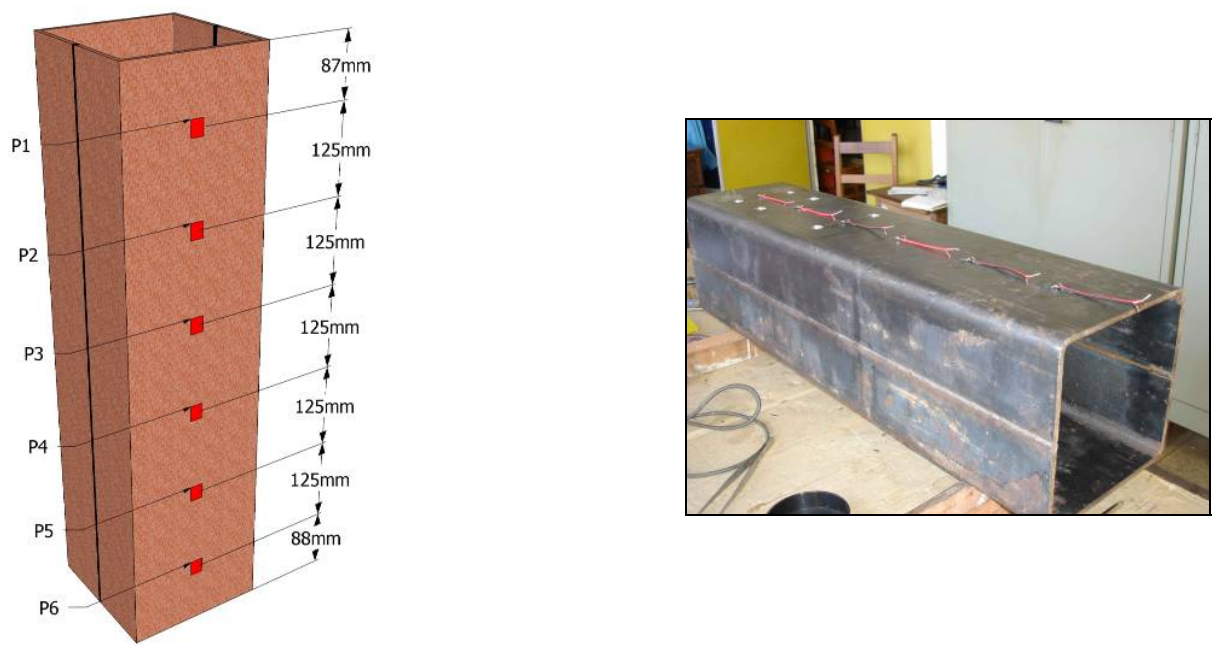

Figura 5-11 - Pontos de instrumentação externa no perfil de aço.

O núcleo de concreto do pilar foi instrumentado com o uso de uma barra lisa de aço, de pequeno diâmetro, imersa na massa de concreto. Os pontos da barra de aço instrumentados (Figura 5-12) correspondem àqueles instrumentados no perfil de aço, desta forma, é possível observar e avaliar a transferência de forças entre os dois materiais.
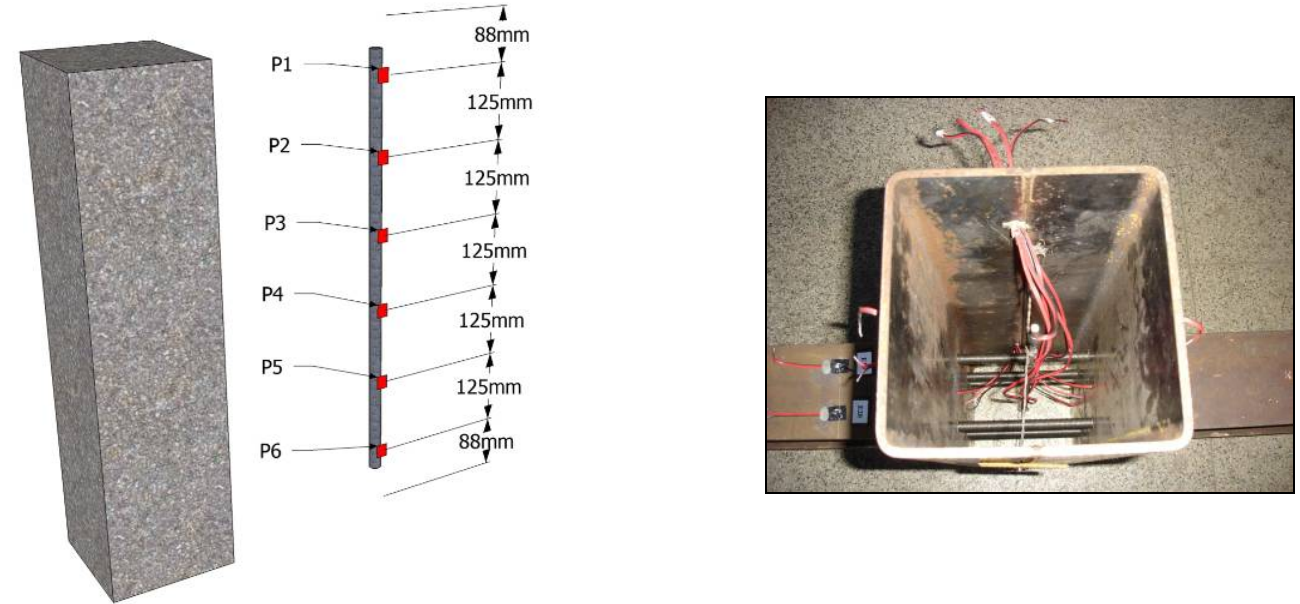

Figura 5-12 - Pontos de instrumentação da barra inserida no núcleo de concreto do pilar misto.

As vigas de aço foram instrumentadas com extensômetros posicionados nas mesas superiores e inferiores e na alma, a uma distância de $12,5 \mathrm{~cm}$ da face do pilar. Os extensômetros na alma foram colocados ao longo da altura da viga, possibilitando obter a posição da linha neutra ao longo do carregamento aplicado. A Figura 5-13 mostra o posicionamento dos extensômetros na viga de aço. 

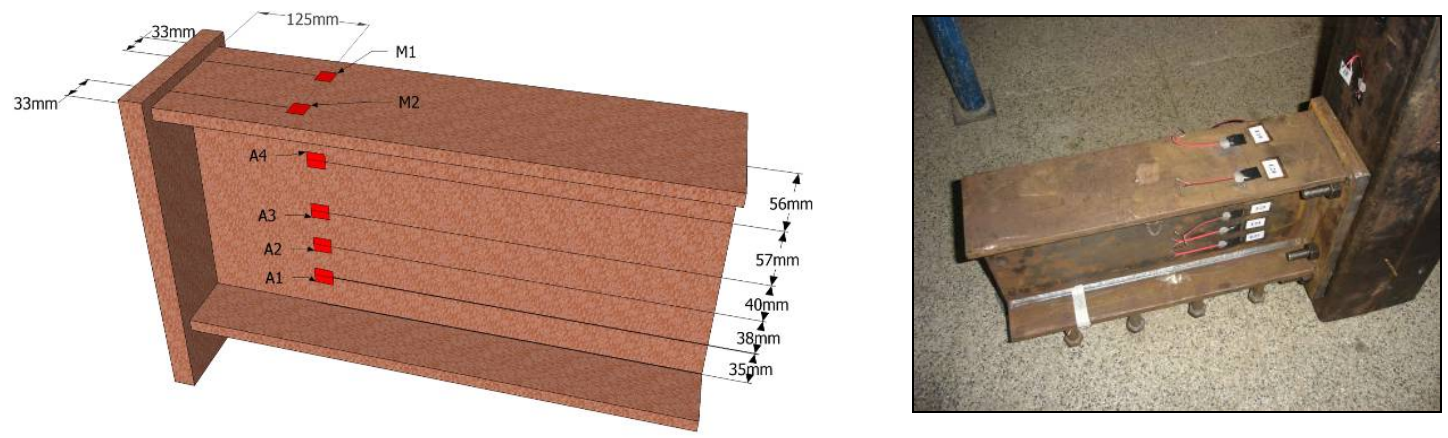

Figura 5-13 - Pontos de instrumentação da Viga metálica da ligação mista.

Os pontos instrumentados nas armaduras de aço da laje de concreto correspondem à mesma linha de instrumentação utilizada nas vigas de aço, ou seja, a uma distância de 12,5 cm da face do pilar preenchido. Foram instrumentadas tanto as armaduras posicionadas na face superior quanto inferior e considerada a simetria do modelo para reduzir a instrumentação das vigas e da laje de concreto armado. Desta forma, para cada modelo só uma viga e um único lado da laje de concreto armado foram instrumentados. A partir da análise dos resultados obtidos, foi possível reduzir a instrumentação da laje de concreto armado. A Figura 5-14 mostra as armaduras da laje de concreto armado que foram instrumentadas.

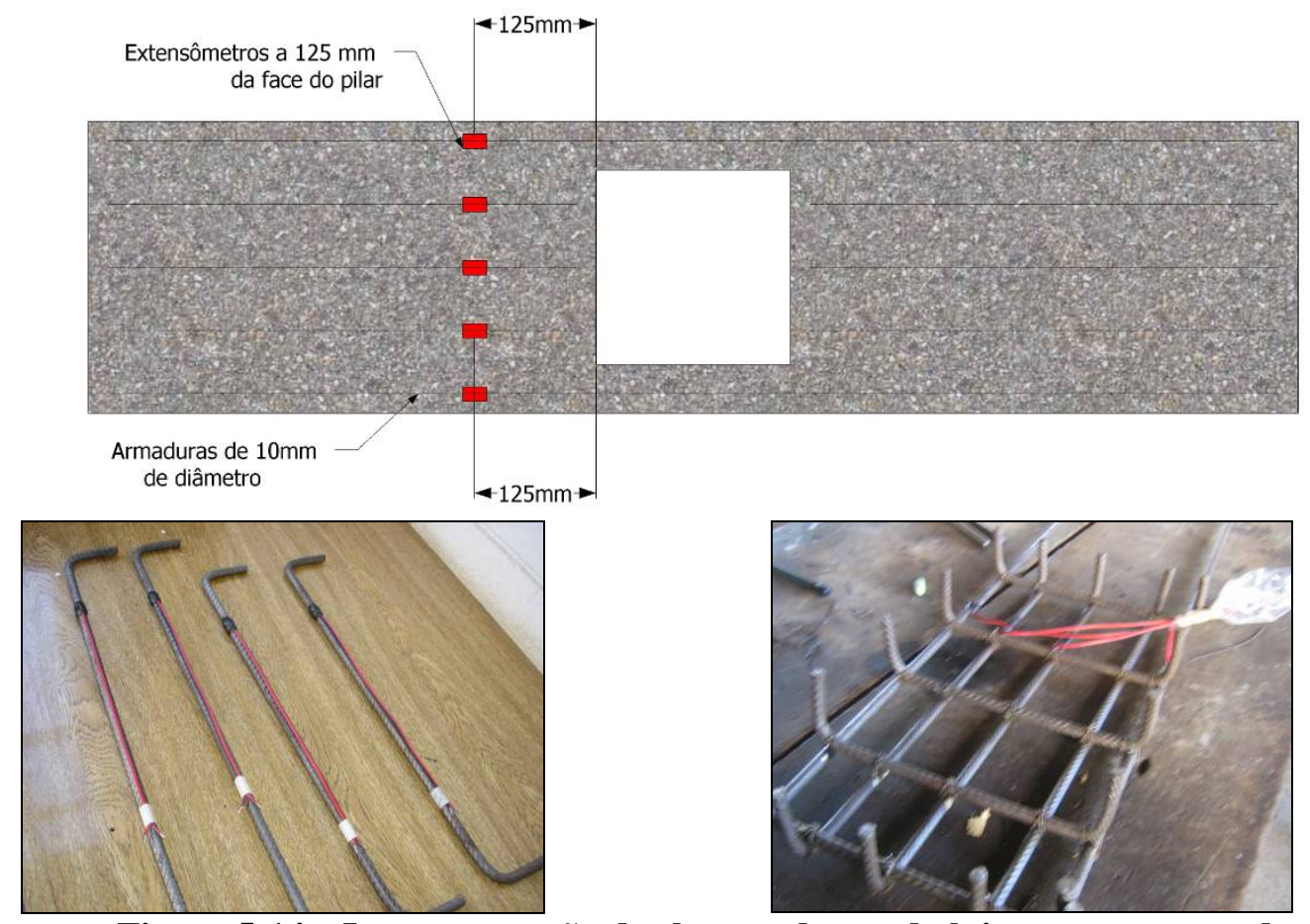

Figura 5-14 - Instrumentação das barras de aço da laje concreto armado. 
Para medir o deslocamento do núcleo de concreto em relação ao perfil de aço, foram utilizados transdutores de deslocamento, tanto na seção de concreto da parte superior (onde a força de compressão foi aplicada) quanto da parte inferior (Figura 5-15).
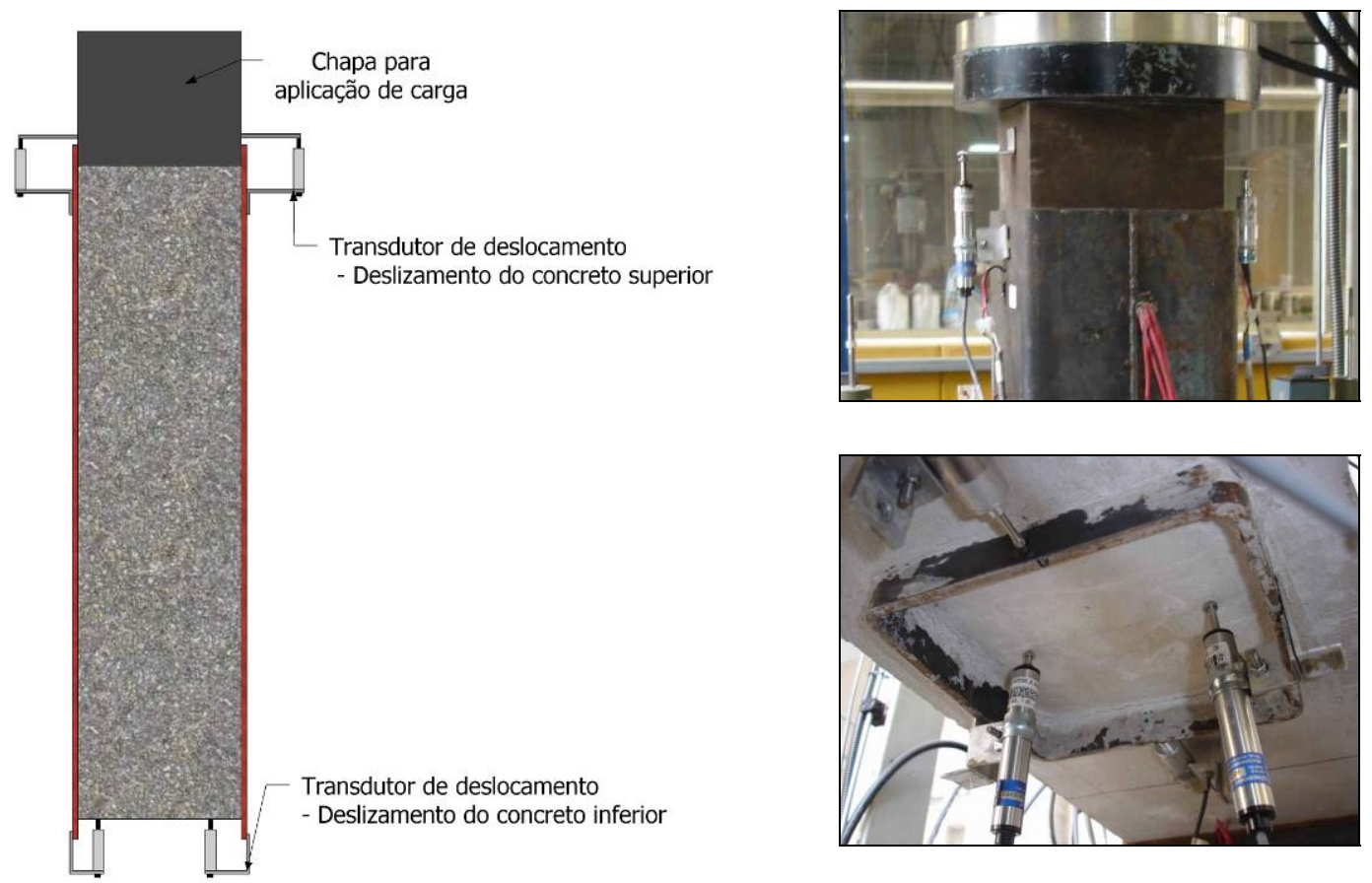

Figura 5-15 - Transdutores de deslocamento para obtenção do deslizamento do concreto.

\subsection{Moldagem do concreto}

Depois dos componentes dos modelos instrumentados (viga de aço, armadura, perfil tubular) a montagem do modelo e o posicionamento das armaduras na fôrma foram realizados. Após a produção do concreto foram moldados corpos-de-prova cilíndricos para a caracterização mecânica do concreto e vigas prismáticas para a realização do ensaio de energia e fraturamento.

Os ensaios de caracterização das propriedades mecânicas do concreto foram realizados no mesmo dia do ensaio do modelo físico. O abatimento do tronco de cone, slump, do concreto foi de 10,1 cm. A Figura 5-16 apresenta alguns detalhes da produção do concreto. 


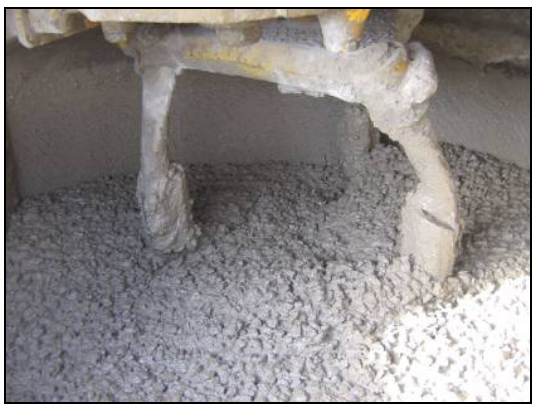

a) Concreto fresco

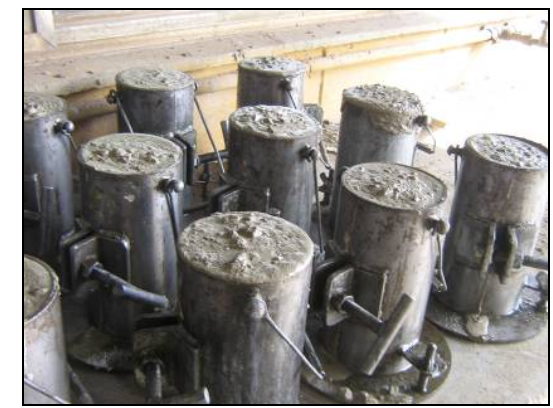

c) Corpos-de-prova cilíndricos para caracterização do concreto

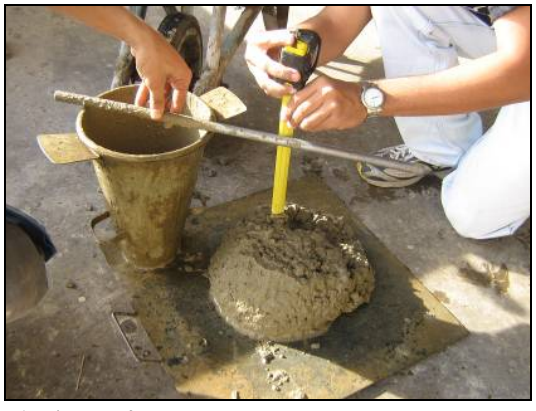

b) Abatimento do tronco de cone

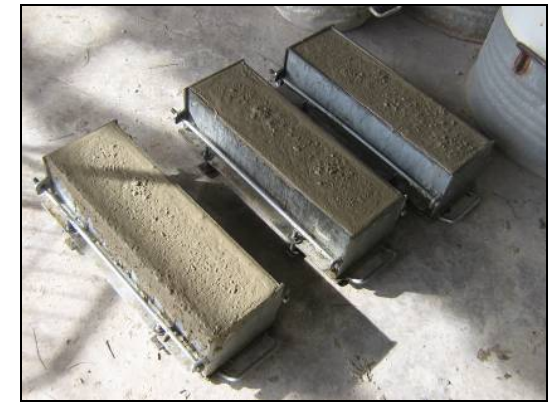

d) Vigas prismáticas para o ensaio de energia de fraturamento

Figura 5-16 - Moldagem e adensamento do concreto.

O adensamento do núcleo de concreto do pilar misto foi realizado com um vibrador de agulha. Destaca-se aqui a relevância do adensamento neste tipo de ensaio, já que a vibração tem uma grande influência na aderência aço-concreto. $O$ vibrador de agulha também foi utilizado no adensamento do concreto da laje. Após a moldagem, a cura do concreto foi realizada ao ar livre, com a laje protegida por uma lona plástica. A retirada das fôrmas e escoramentos foi realizada sete dias após a concretagem. A Figura 5-17 mostra as etapas de moldagem e adensamento do concreto no modelo de ligação.

Os ensaios dos modelos físicos foram realizados na máquina servo-controlada INSTRON 8506, com capacidade de carga de 2500 kN. A aplicação da carga foi realizada com controle de deslocamento do atuador com velocidade de 0,05 mm/s. A Tabela 5-4 traz um resumo dos equipamentos utilizados ao longo da análise experimental. 


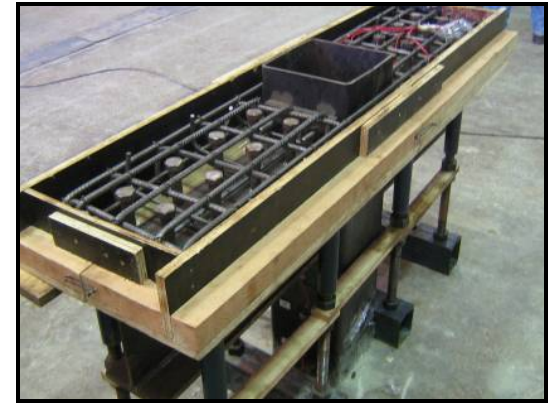

a) Modelo físico antes da moldagem do concreto

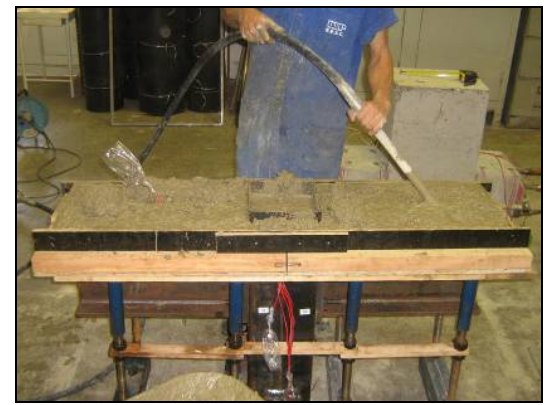

c) Adensamento do concreto da laje

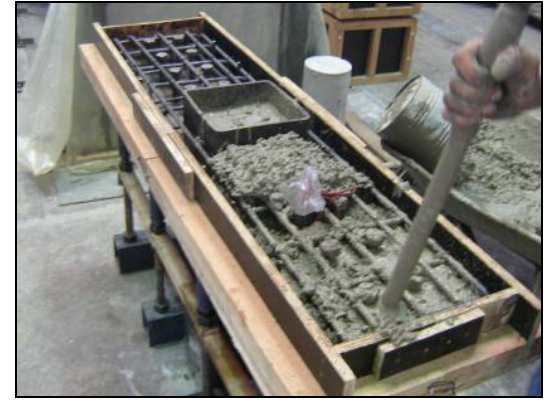

b) Adensamento do concreto da laje e do núcleo de concreto

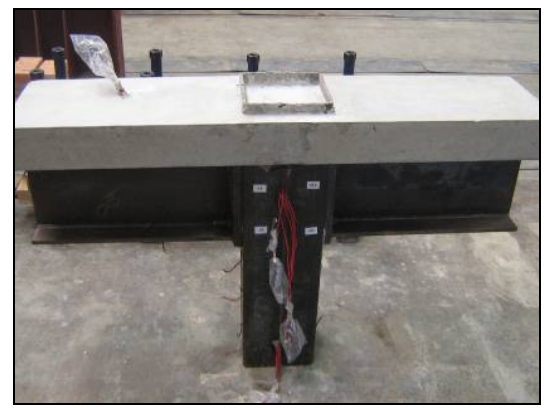

d) Modelo experimental após a cura do concreto

Figura 5-17 - Moldagem e adensamento do concreto.

Tabela 5-4 - Equipamentos utilizados na investigação experimental.

\begin{tabular}{|c|c|c|}
\hline Equipamento & Função & Utilização \\
\hline $\begin{array}{l}\text { Máquina de aplicação de força } \\
\text { ELE - Capacidade de } 500 \mathrm{kN} \text {. }\end{array}$ & Aplicação de força & $\begin{array}{l}\text { Ensaios de resistência à compressão, } \\
\text { módulo de elasticidade e resistência à } \\
\text { tração do concreto. }\end{array}$ \\
\hline $\begin{array}{l}\text { Maquina de ensaio EMIC - } \\
\text { Capacidade de } 1000 \mathrm{kN}\end{array}$ & Aplicação de força & $\begin{array}{l}\text { Ensaio de tração uniaxial para } \\
\text { caracterização do aço }\end{array}$ \\
\hline $\begin{array}{c}\text { Maquina servo-controlada } \\
\text { INSTRON } 8506 \text { - Capacidade } \\
\text { de } 2500 \mathrm{kN}\end{array}$ & Aplicação de força & Ensaio dos modelos físicos \\
\hline $\begin{array}{l}\text { Módulo de aquisição de dados } \\
\text { - VISHAY SYSTEM } 5000\end{array}$ & $\begin{array}{l}\text { Aquisição dos dados dos } \\
\text { extensômetros e } \\
\text { transdutores }\end{array}$ & $\begin{array}{l}\text { Registro de deformação e } \\
\text { deslocamento nos modelos físicos }\end{array}$ \\
\hline $\begin{array}{l}\text { Extensômetros elétricos de } \\
\text { resistência - KYOWA }\end{array}$ & Medição de deformação & $\begin{array}{l}\text { Medição das deformações no concreto } \\
\text { e no aço }\end{array}$ \\
\hline $\begin{array}{c}\text { Transdutores de deslocamento } \\
\text { - KYOWA }\end{array}$ & Medição de deslocamento & $\begin{array}{l}\text { Medição do deslocamento relativo do } \\
\text { concreto e rotação da ligação }\end{array}$ \\
\hline
\end{tabular}




\subsection{Procedimento de ensaio}

Após a cura do concreto, os modelos foram transportados para a realização do ensaio experimental. A força de compressão foi aplicada apenas na seção de concreto, visando promover o deslocamento relativo entre perfil de aço e núcleo de concreto e, com isso, mobilizar os mecanismos de aderência na interface aço-concreto. Para a aplicação da força foi utilizada uma chapa rígida em contato apenas com a seção de concreto. Para a regularização da superfície de aplicação da força foi utilizada areia; esta foi uma tentativa de evitar a ocorrência de algum efeito localizado e melhorar a distribuição da força aplicada. A velocidade adotada para o carregamento foi de $0,05 \mathrm{~mm} / \mathrm{s}$.

\subsubsection{Modelo CC_W}

O primeiro modelo, apesar da ausência de conectores de cisalhamento no pilar, apresentou um desempenho superior ao esperado. Deve-se isso, provavelmente, ao efeito benéfico da laje de concreto armado na rigidez da ligação. A Figura 5-18 mostra o modelo CC_W durante a realização do ensaio.
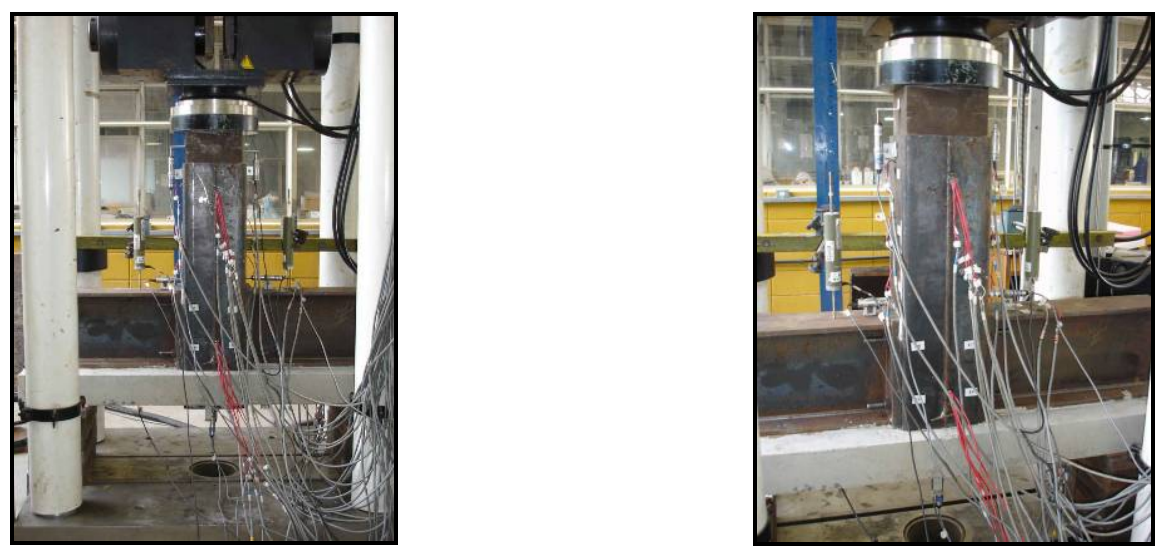

Figura 5-18 - Ensaio do Modelo CC_W 
No início do carregamento, até $300 \mathrm{kN}$, praticamente não foram registradas deformações nos extensômetros. Até esta etapa, o deslocamento relativo do núcleo de concreto e a rotação da ligação apresentavam valores muito baixos. Acredita-se que até este ponto a laje forneceu grande rigidez ao modelo diminuindo, assim, as deformações nas vigas e perfil de aço. Superado este valor de carregamento, ocorreu o aparecimento das primeiras fissuras na laje de concreto, localizadas na parte inferior da laje, próximo ao pilar. As primeiras fissuras ocorreram também na face superior da laje próxima a região de apoio, nas proximidades da viga de aço. A Figura 5-19 ilustra claramente as primeiras fissuras que surgiram nas duas regiões: região central e região próxima ao apoio.
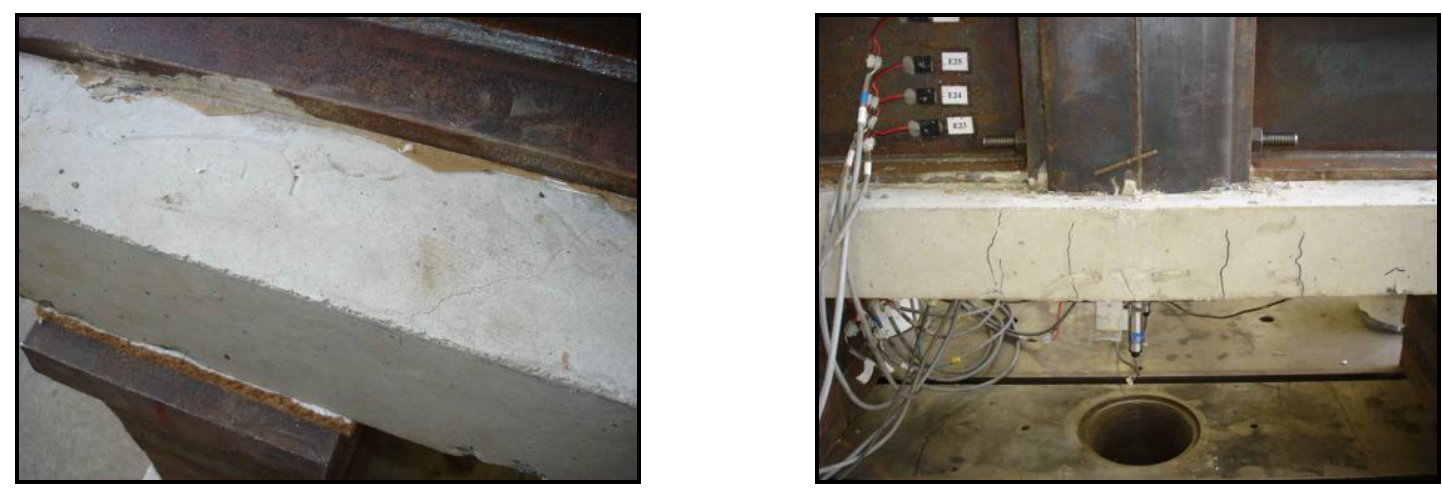

Figura 5-19 - Aparecimento das primeiras fissuras no modelo CC_W

Quando a força aplicada atingiu cerca de $370 \mathrm{kN}$, a fissuração da laje de concreto tornou-se mais intensa e começaram a aparecer deformações significativas nas armaduras. A deformação de outros componentes do modelo de ligação (viga de aço e pilar) começa a se intensificar a partir deste instante, ou seja, passa a ocorrer perda de rigidez da laje devido à fissuração e sua contribuição para a rigidez da ligação diminui. A Figura 5-20 mostra a fissuração da região de apoio e as fissuras na parte inferior da laje, junto ao pilar preenchido. Após esta etapa de carregamento, apesar da intensa fissuração do concreto da laje, o modelo ainda apresentou ganho de capacidade resistente. 

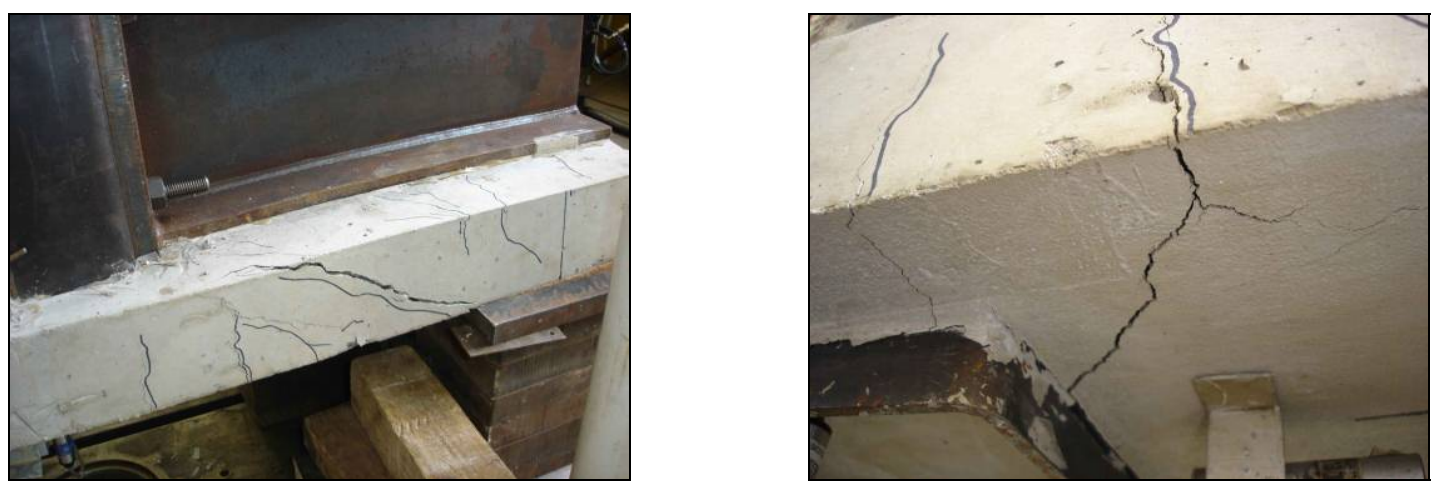

Figura 5-20 - Fissuração na laje do modelo CC_W

Para uma força de $370 \mathrm{kN}$, as armaduras da laje e os componentes de aço da ligação contribuem com uma parcela significativa da resistência à flexão do modelo. O ensaio do Modelo CC_W prosseguiu até atingir uma força de compressão de 874 kN. Após atingir este valor, o modelo não apresentou mais ganho de resistência com a aplicação de deslocamento no núcleo de concreto. Acredita-se que a plastificação das armaduras da laje foi a responsável pelo avanço das deformações no modelo, sem ganho adicional de resistência e sem o aumento no deslizamento do núcleo de concreto em relação ao perfil de aço. A Figura 5-21 mostra o deslizamento do núcleo de concreto e o deslocamento do pistão no modelo CC_W.

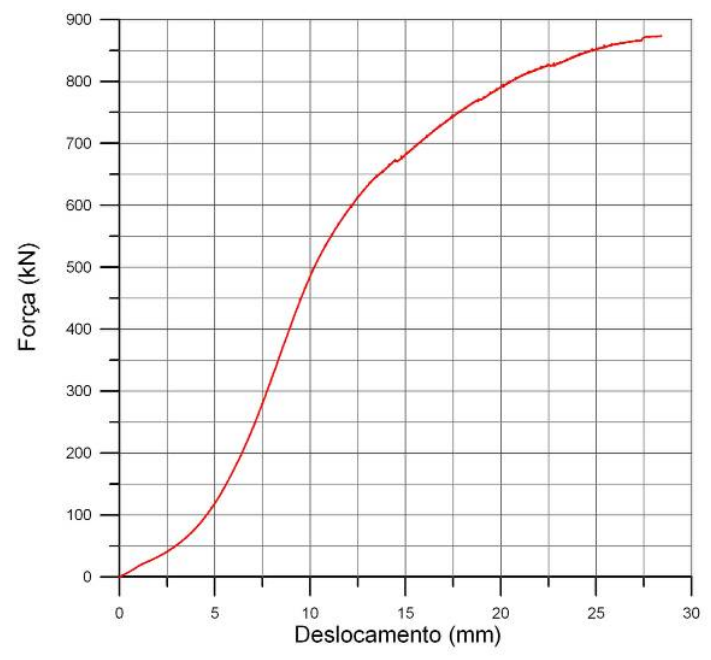

a) Deslocamento do pistão

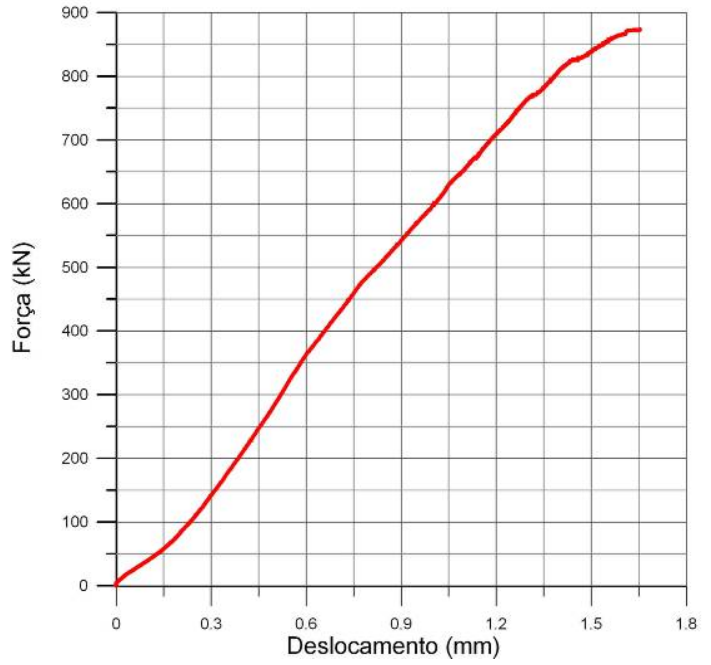

b) Deslizamento na face superior do concreto

Figura 5-21 - Deslizamento do núcleo de concreto e deslocamento do pistão no modelo CC_W 
A partir da análise das deformações nas armaduras da laje foi possível perceber que aquelas mais próximas ao eixo das vigas foram menos solicitadas que aquelas localizadas nas extremidades da laje. A Figura 5-22 mostra a relação entre a força aplicada no núcleo de concreto e as deformações nas armaduras da laje. Foi representado graficamente limite elástico teórico de deformação das armaduras por uma reta.

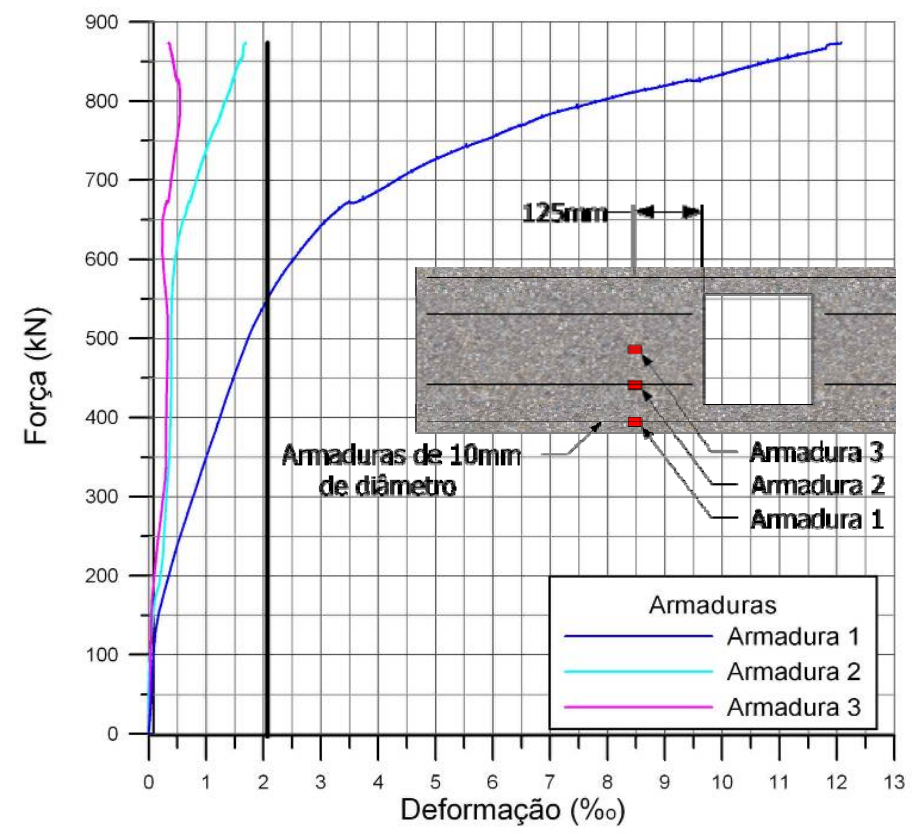

Figura 5-22 - Deformação axial nas armaduras da laje de concreto

A partir das deformações registradas na alma e na mesa da viga, é possível estimar a posição da linha neutra na viga mista e compreender melhor o comportamento da ligação com o avanço do carregamento aplicado. A Figura 5-23 mostra as deformações nas mesas e na alma da viga de aço. A configuração da linha neutra na viga de aço, para vários níveis de carregamento é exposta na Figura 5-24. 


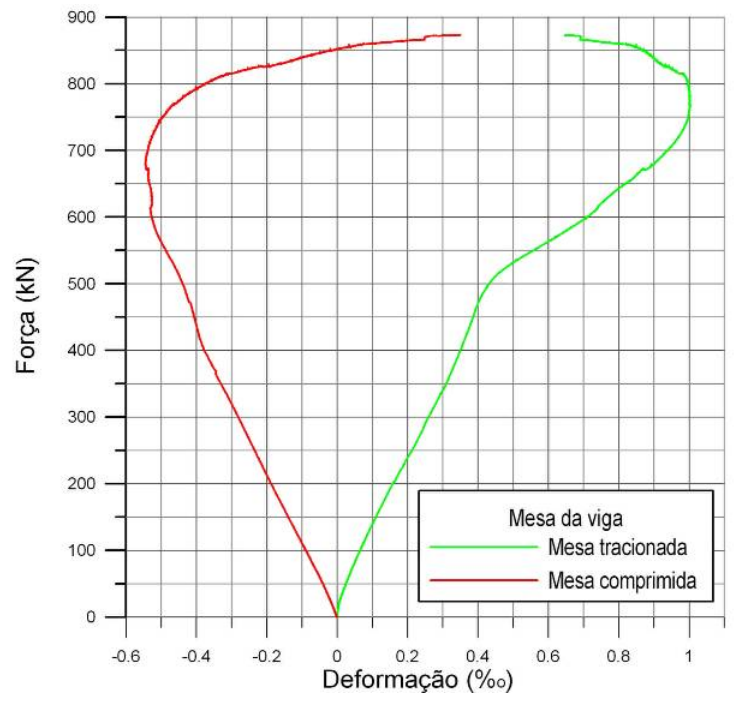

a) Deformações nas mesas da viga

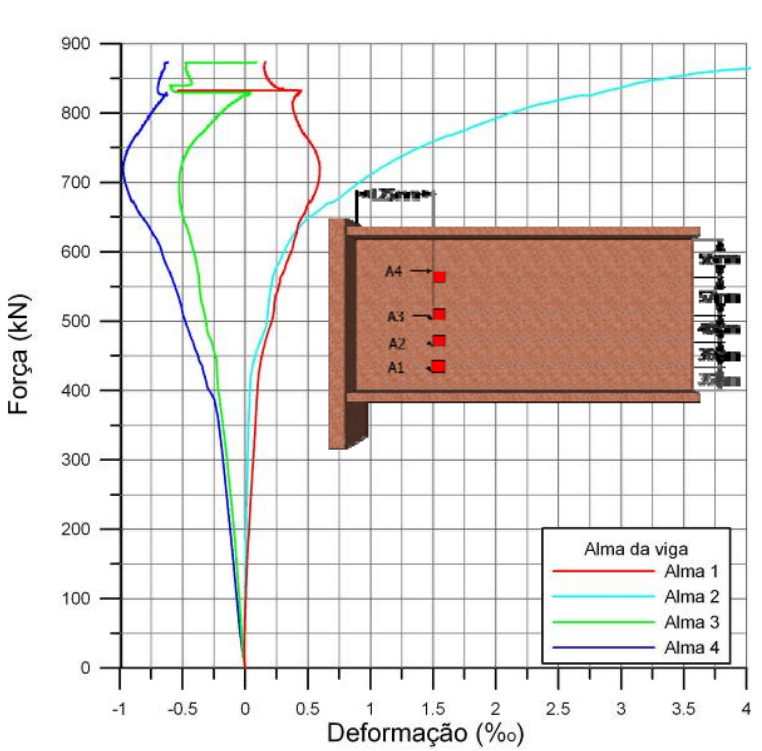

b) Deformações na alma da viga

Figura 5-23 - Deformações na viga metálica - Modelo CC_W.

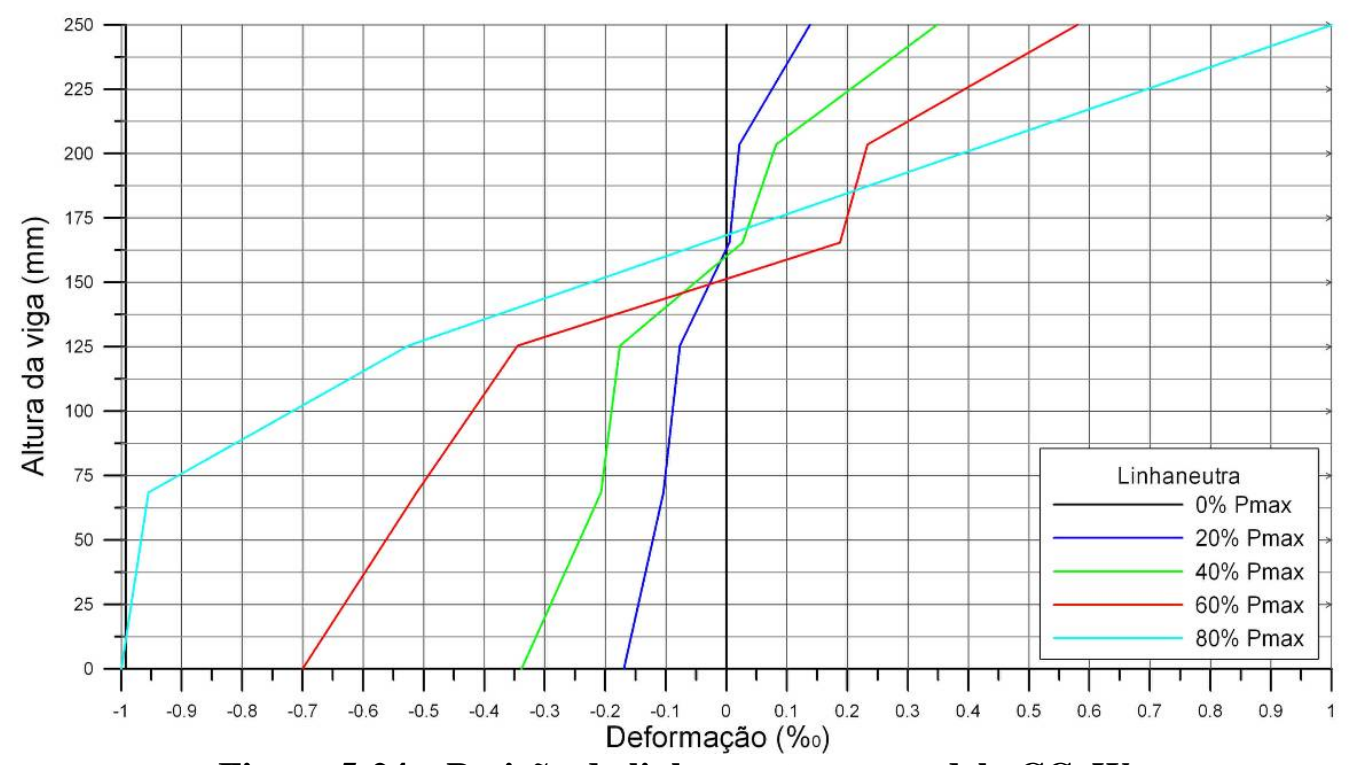

Figura 5-24 - Posição da linha neutra no modelo CC_W.

As leituras de deformação no tubo de aço e no núcleo de concreto do pilar preenchido possibilitaram observar a transferência de tensões entre os dois materiais. Entretanto, os valores de deformação no tubo de aço, na região da ligação, apresentaram grande variação, provavelmente devido à perturbação da flexão da viga. Desta forma, estes valores foram desprezados ou corrigidos. A Figura 5-25 apresenta a transferência de tensões entre aço e 
concreto, para diferentes níveis de carregamento e em função do comprimento do perfil de aço.

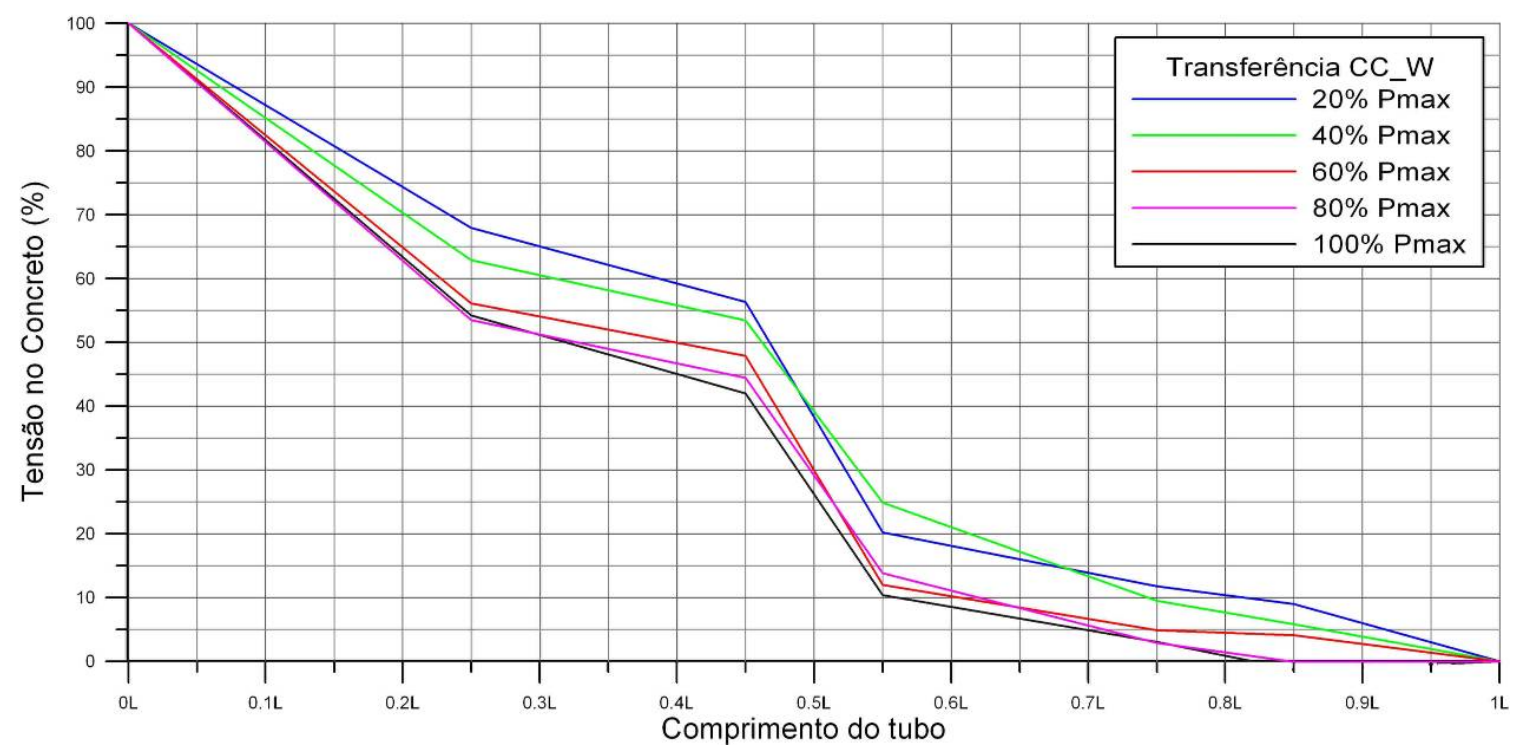

Figura 5-25 - Transferência de tensões em função do nível de carregamento e do comprimento da altura do pilar: modelo CC_W

Observa-se que a transferência de tensões ocorre de forma mais acentuada na região inicial do pilar preenchido, nos trechos entre 0,4L e 0,6L, onde L representa a altura do pilar. Nos estágios finais de carregamento, a transferência de tensões entre os dois materiais também é mais intensa; deve-se isto, provavelmente, à fissuração do concreto no pilar, ao nível das tensões no mesmo ou à rotação mais acentuada da ligação, o que ocasiona um aumento na parcela de aderência mecânica.

\subsubsection{Modelo CC_SB}

O modelo CC_SB é idêntico ao modelo CC_W, apenas com a presença de conectores de cisalhamento do tipo pino com cabeça (“stud-bolt”) no pilar misto. O uso dos conectores de cisalhamento nesta região tem a função de promover a transferência de forças entre o concreto e o aço no pilar misto preenchido, promovendo o trabalho conjunto entre os dois 
materiais. Os códigos normativos determinam o uso de conectores de cisalhamento no pilar misto, na região correspondente à ligação, para que não ocorra deslizamento relativo significativo entre os materiais. Sendo assim, espera-se que os modelos CC_SB e CC_AN apresentem um melhor desempenho quando comparado ao modelo CC_W (sem conectores).

O aparecimento das primeiras fissuras na laje do modelo CC_SB ocorreu na região próxima ao pilar misto para uma força aplicada de aproximadamente 230 kN (Figura 5-26a). Este valor é inferior ao registrado no modelo anterior, sem conectores de cisalhamento. Semelhante ao que ocorreu no modelo CC_W, as primeiras fissuras apareceram na região próxima ao pilar e próximo ao apoio (na região superior da laje). A Figura 5-26 mostra o modelo CC_SB com as primeiras fissuras.

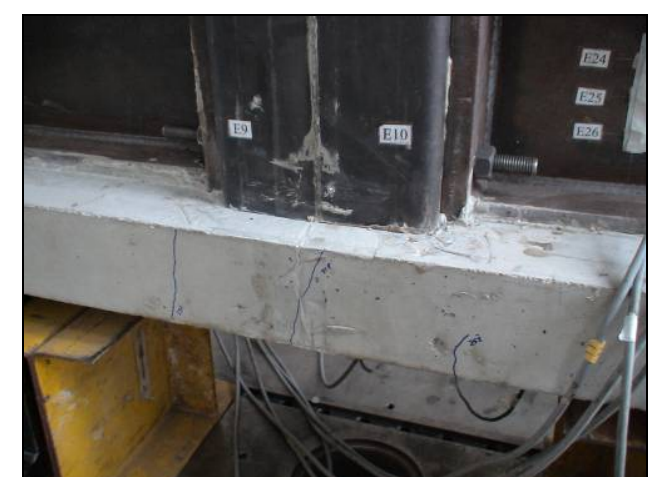

a) Aparecimento das primeiras fissuras Modelo CC_SB

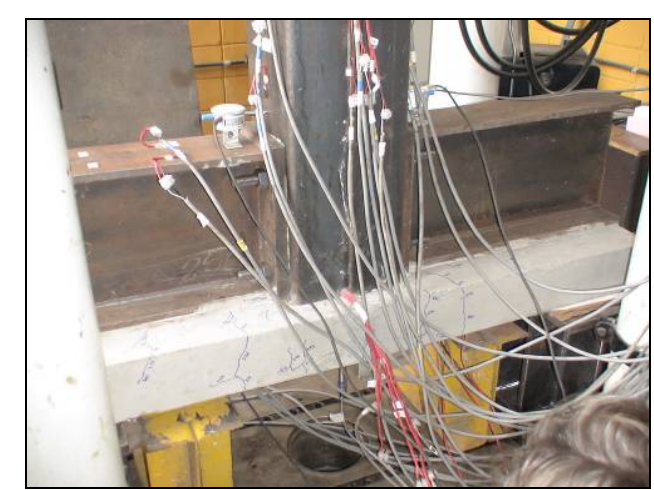

b) Fissuras na região próxima ao pilar e próxima ao apoio

Figura 5-26 - Fissuras iniciais no modelo CC_SB

O ensaio do Modelo CC_SB prosseguiu até ser atingida uma força de $790 \mathrm{kN}$. Antes de atingir esta carga o Modelo CC_SB apresentou comportamento bastante variável, apresentou-se instável com queda e aumento do ganho de resistência ao longo da aplicação do deslocamento, sempre atingindo o pico de carga de $790 \mathrm{kN}$. Nesta etapa do ensaio, a laje de concreto já se encontrava totalmente fissurada e as armaduras da extremidade estavam em regime de escoamento. A Figura 5-27 mostra curvas relacionando a força aplicada com o deslocamento do pistão e com o deslizamento relativo do concreto. 


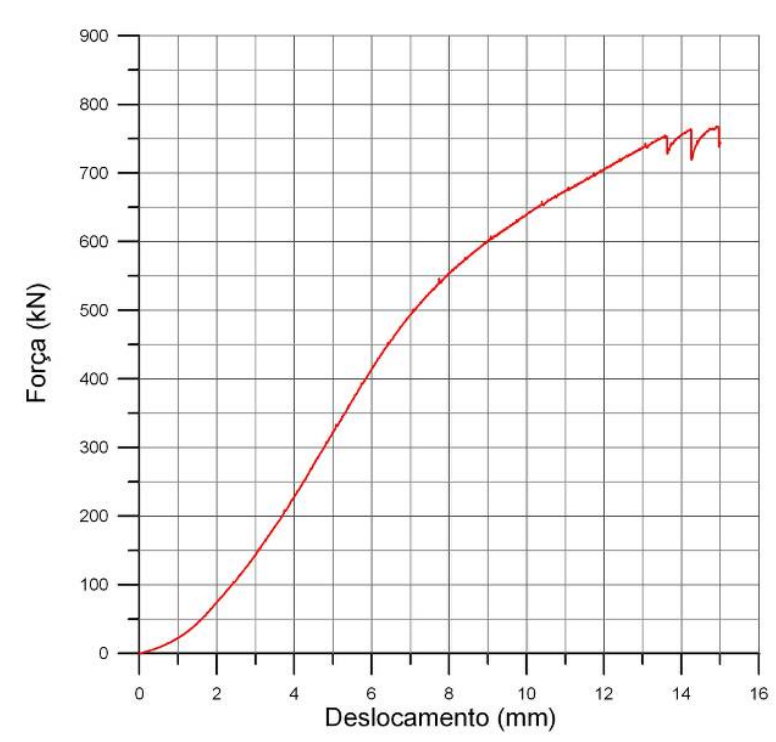

a) Deslocamento do pistão

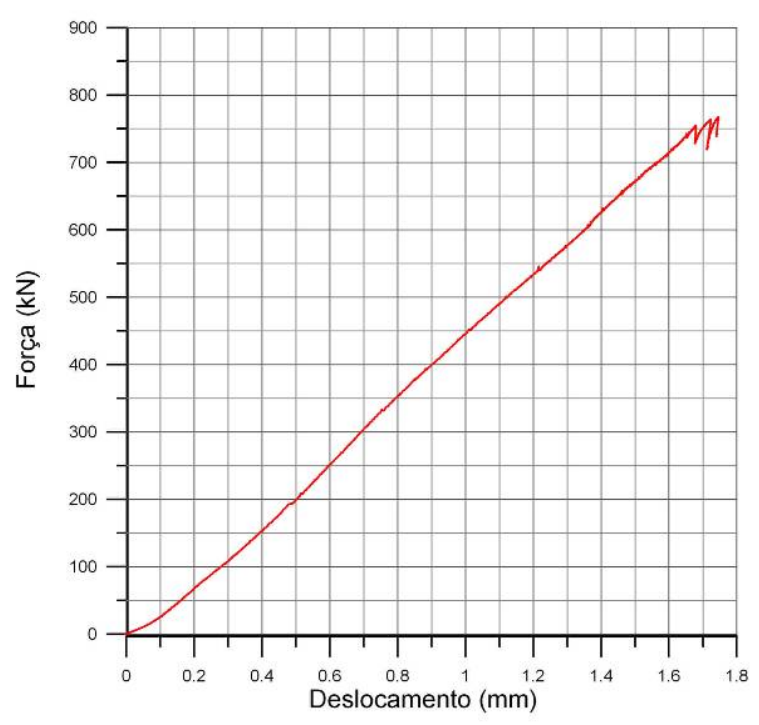

b) Deslizamento na face superior do concreto

Figura 5-27 - Deslizamento do núcleo de concreto e deslocamento do pistão no modelo CC_SB

Da mesma forma que o modelo CC_W, a deformação das armaduras da laje do modelo CC_SB foi mais intensa nas extremidades (Figura 5-28).

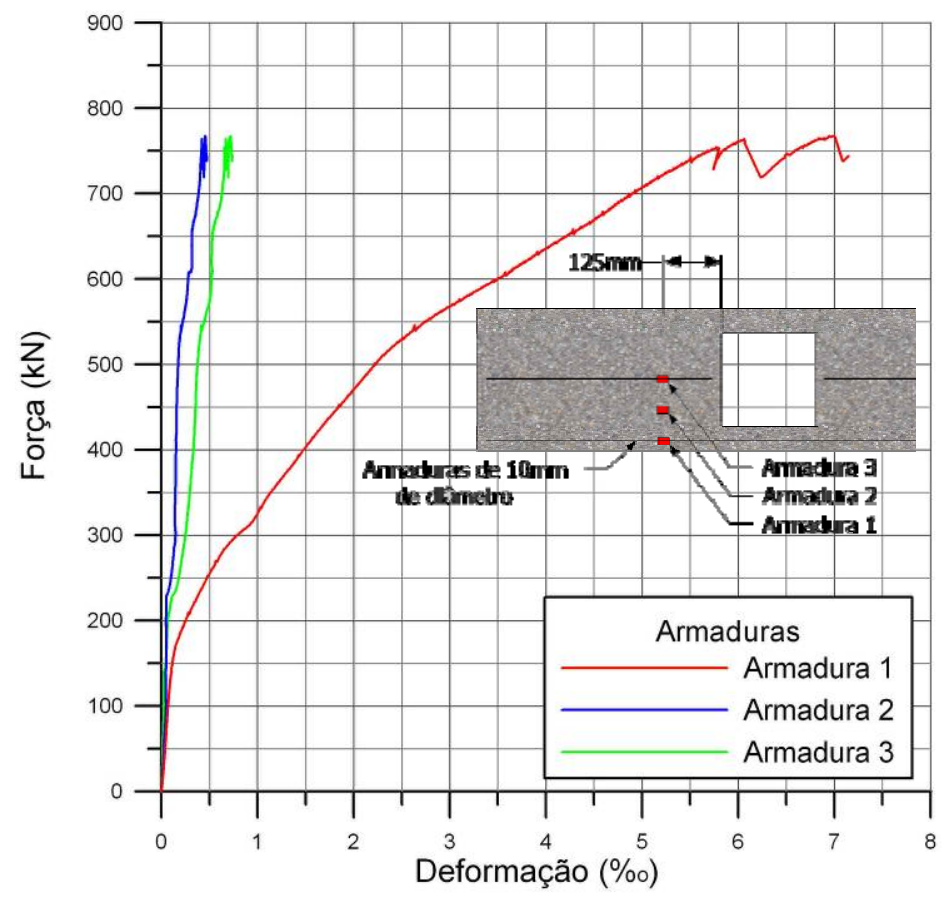

Figura 5-28 - Deformação nas armaduras da laje

As deformações nas vigas metálicas do modelo CC_SB apresentaram comportamento bastante diferente do modelo anterior. A partir das deformações pode-se estimar a posição da 
linha neutra na viga metálica em função do carregamento aplicado no pilar. A Figura 5-29 mostra a distribuição das deformações nas almas e mesas da viga e a Figura 5-30 traz a variação da posição da linha neutra.

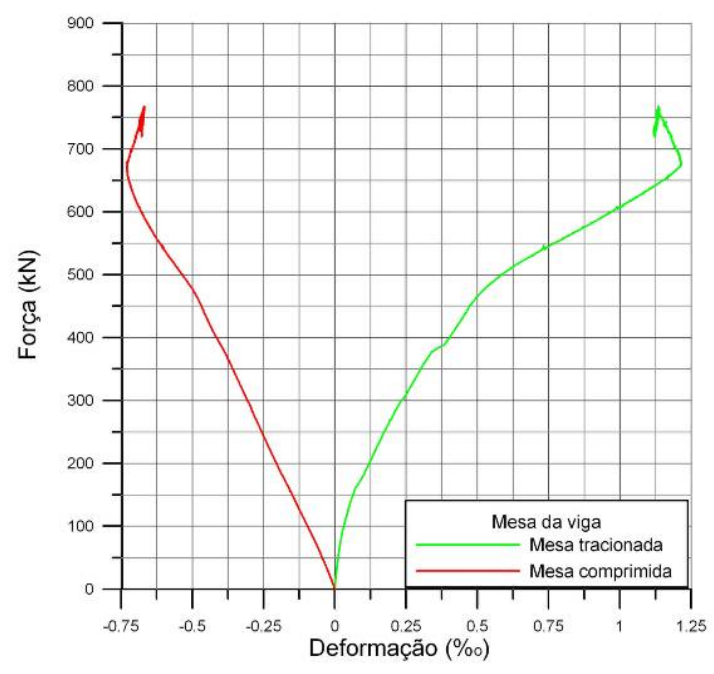

a) Deformações médias nas mesas

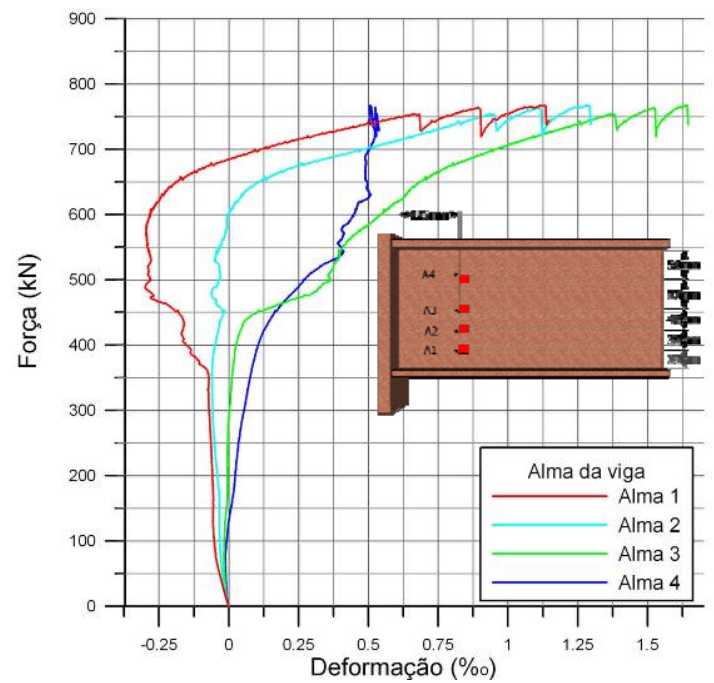

b) Deformações na alma

Figura 5-29 - Deformações medidas na viga de aço - Modelo CC_SB.

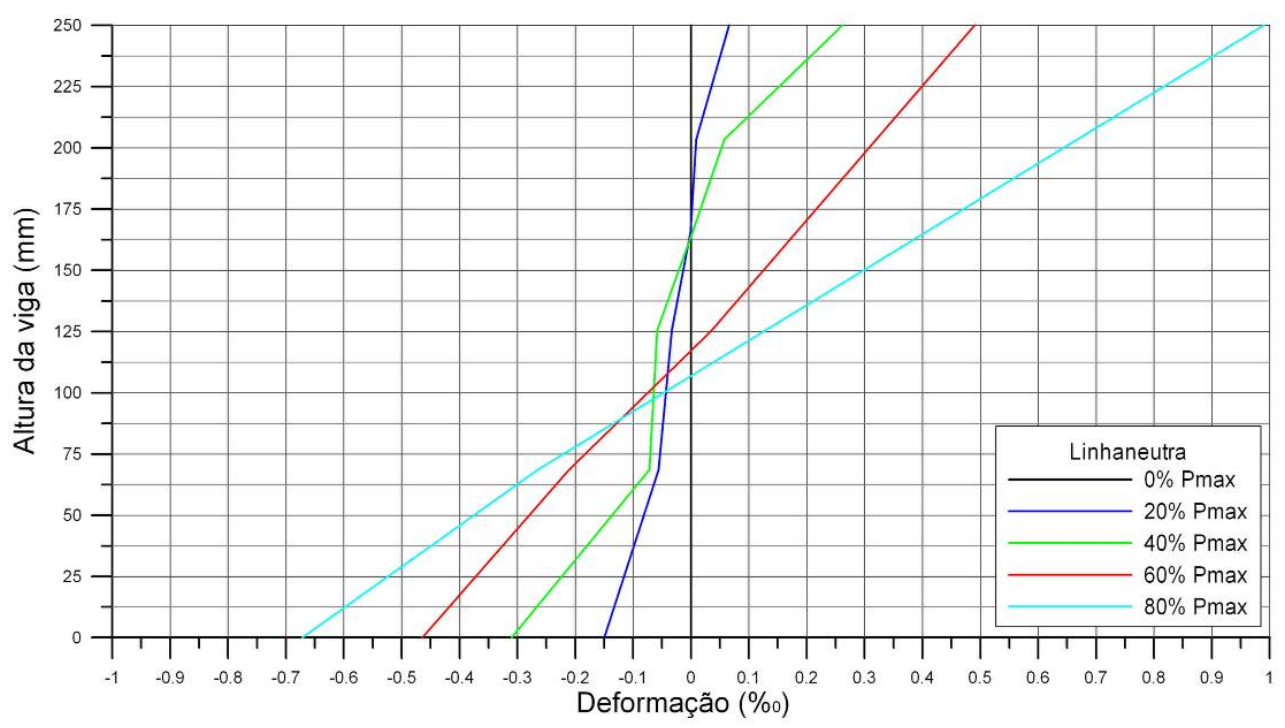

Figura 5-30 - Estimativa da linha neutra na viga metálica - Modelo CC_SB.

As leituras de deformação no perfil de aço do pilar preenchido e no núcleo de concreto permitiram estimar a transferência de forças entre os dois materiais em função do aumento da força aplicada. A Figura 5-31 mostra a estimativa da transferência de tensões entre os dois materiais ao longo do comprimento do pilar. 


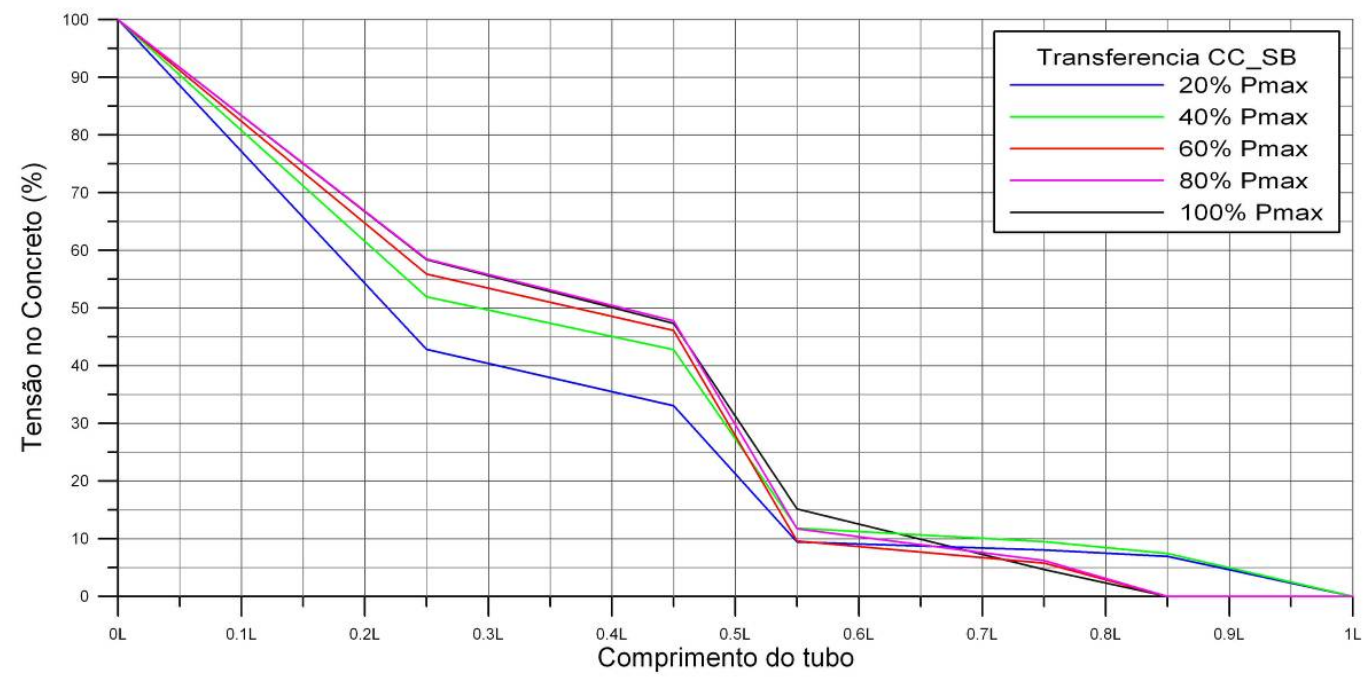

Figura 5-31 - Transferência de forças entre o concreto e o aço - Modelo CC_SB.

A transferência de forças do núcleo de concreto para o perfil é mais acentuada no trecho entre $0,4 \mathrm{~L}$ e $0,6 \mathrm{~L}$, que corresponde à região que está localizada no topo do pilar. A comparação destes valores com os dos outros modelos pode prever a influência dos conectores. Nota-se que para os estágios finais de carregamento a transferência de tensões ocorre de forma completa logo após o trecho de 0,8 L.

\subsubsection{Modelo CC_AN}

O modelo CC_AN se diferencia do demais apenas pelo tipo de conector; neste caso são perfis cantoneira como conectores de cisalhamento no pilar misto. A distribuição das cantoneiras no interior do pilar é idêntica à utilizada no modelo com conectores tipo pino com cabeça. O objetivo da inserção das cantoneiras é melhorar a transferência de forças entre o núcleo de concreto e o perfil tubular.

A fissuração da laje de concreto se iniciou com baixas cargas, entre 120 kN e 170 kN e as primeiras fissuras apareceram na região próxima ao apoio na parte superior da laje. Outras fissuras nas proximidades do pilar misto também surgiram para este nível de carregamento. 
Embora a fissuração da laje tenha iniciado para uma força aplicada de valor inferior ao observado nos demais modelos, a intensificação da fissuração ocorreu apenas para uma força de aproximadamente 570 kN. A Figura 5-32 mostra a formação das primeiras fissuras no Modelo CC_AN e a sua intensificação.

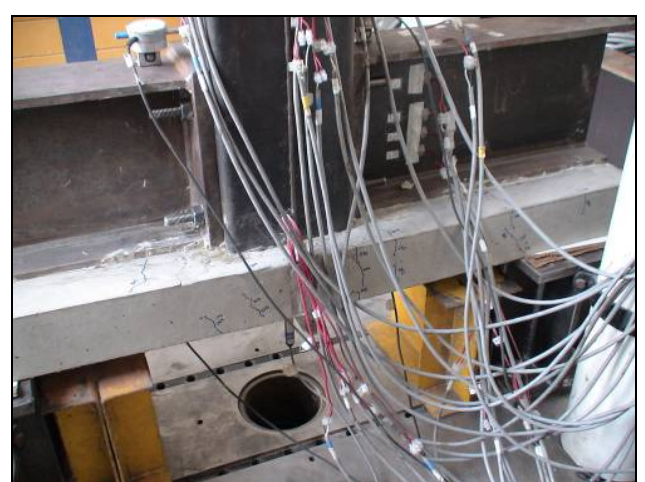

a) Fissuras iniciais na laje de concreto

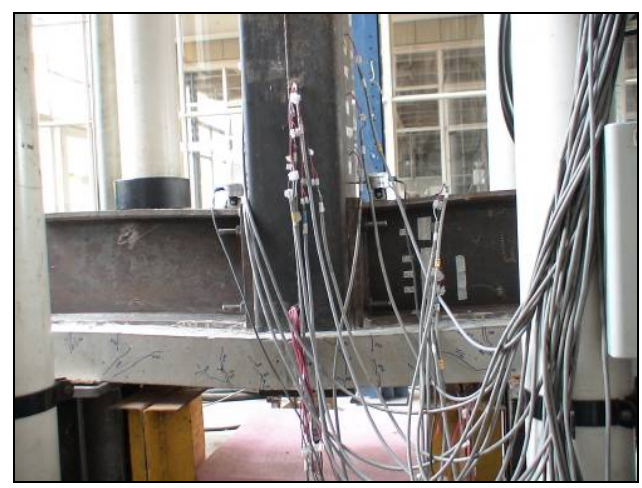

b) Intensificação das fissuras

Figura 5-32 - Fissuração da laje do modelo CC_AN

O ensaio do Modelo CC_AN foi realizado até atingir a força máxima de 820 kN e foi encerrado pois já não havia mais acréscimo na força aplicada, somente nos deslocamentos e deformações registrados. Este modelo apresentou, aparentemente, fissuração mais intensa que a observada na laje do modelo CC_SB. No estágio final de carregamento, a viga apresentou grande deformação e ocorreu também a plastificação das armaduras. Na Figura 5-33 são mostrados o comportamento do deslocamento do pistão e do deslizamento relativo do núcleo de concreto, ambos em função da força aplicada. 


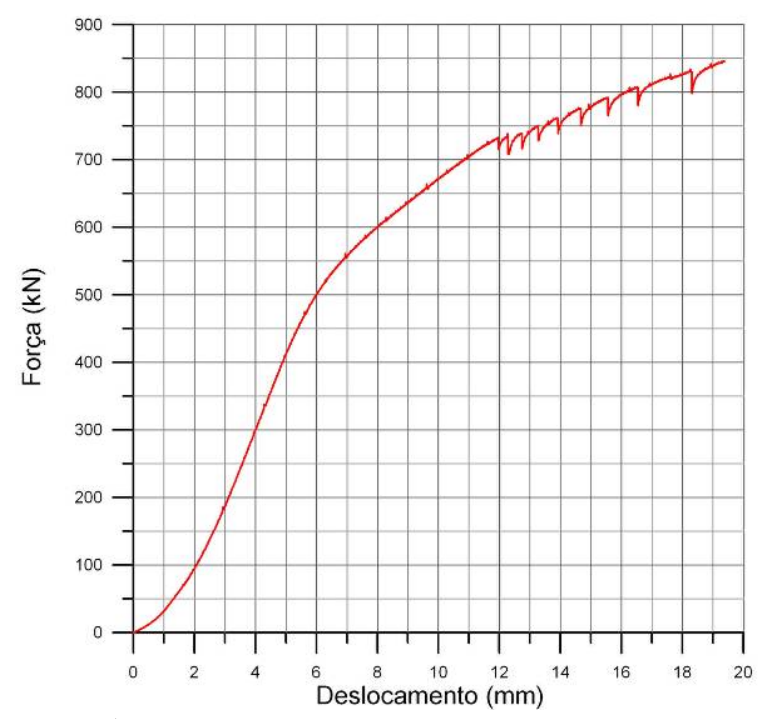

a) Força $x$ Deslocamento do atuador

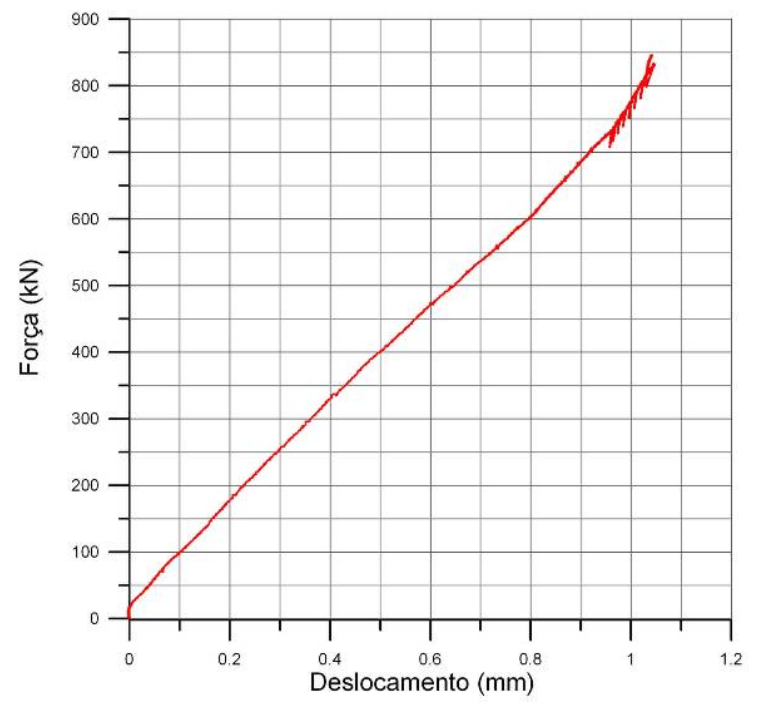

b) Força $x$ Deslizamento do concreto

Figura 5-33 - Gráficos de Força aplicada versus Deslocamento: modelo CC_AN

A deformação nas armaduras da laje foram superiores nas armaduras localizadas nas bordas. A Figura 5-34 apresenta a deformação nas armaduras da laje do modelo CC_AN.

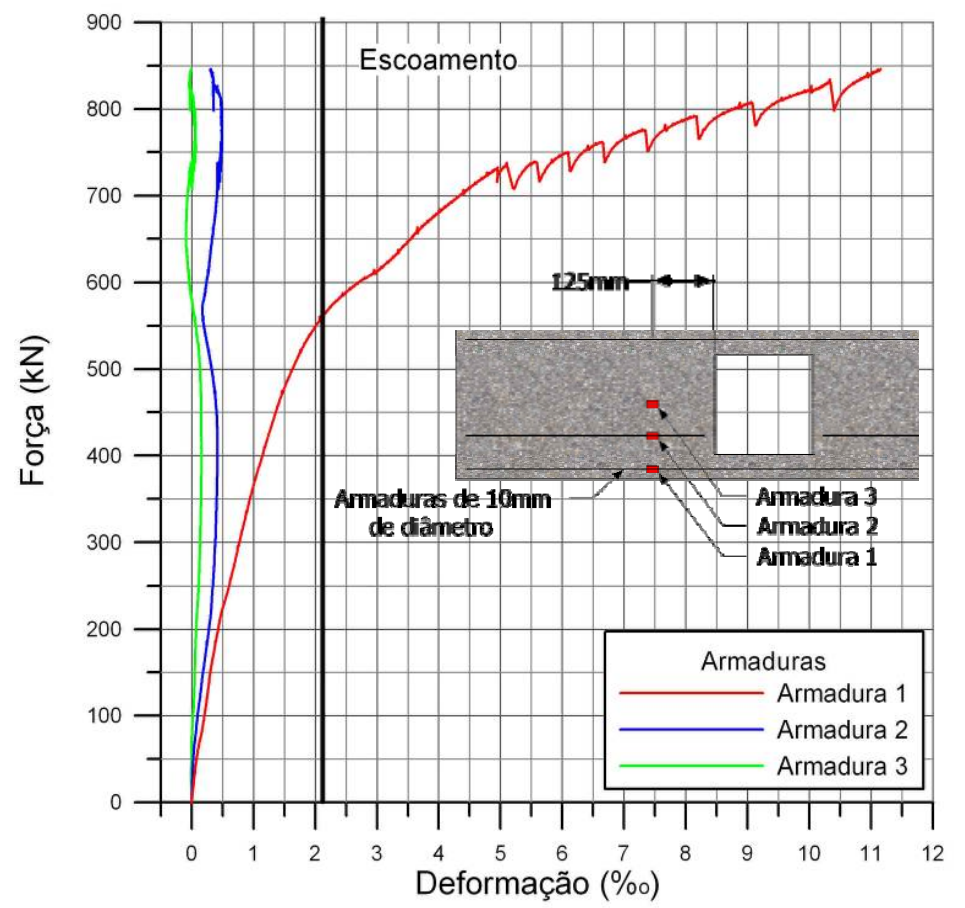

Figura 5-34 - Deformação das armaduras no modelo CC_AN

As deformações nas vigas de aço do modelo CC_AN foram diferenciadas do modelo anterior. A partir das deformações nas mesas e alma é possível estimar a posição da linha 
neutra para diferentes etapas de carregamento. A Figura 5-35 mostra a distribuição das deformações nas mesas e alma da viga e a Figura 5-36 traz a variação na posição da linha neutra.

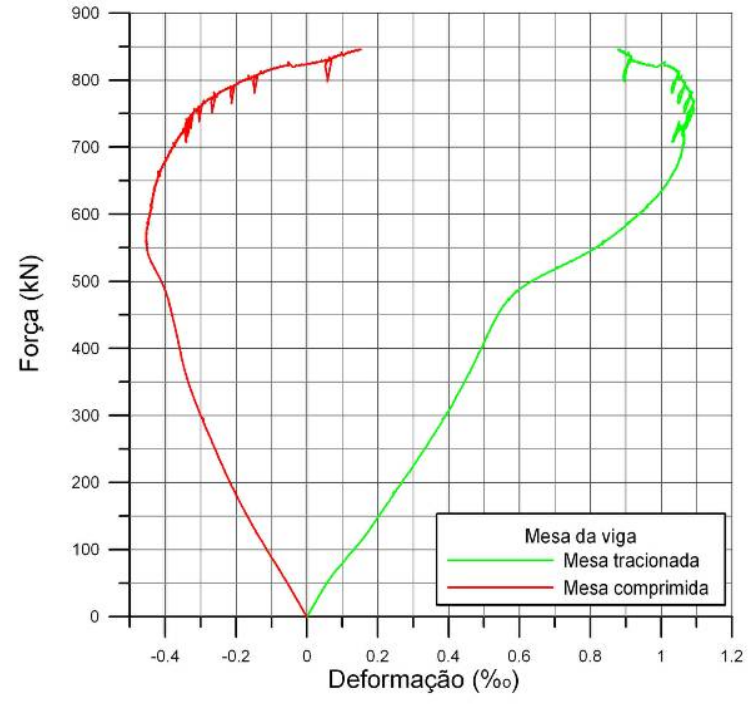

a) Deformações nas mesas

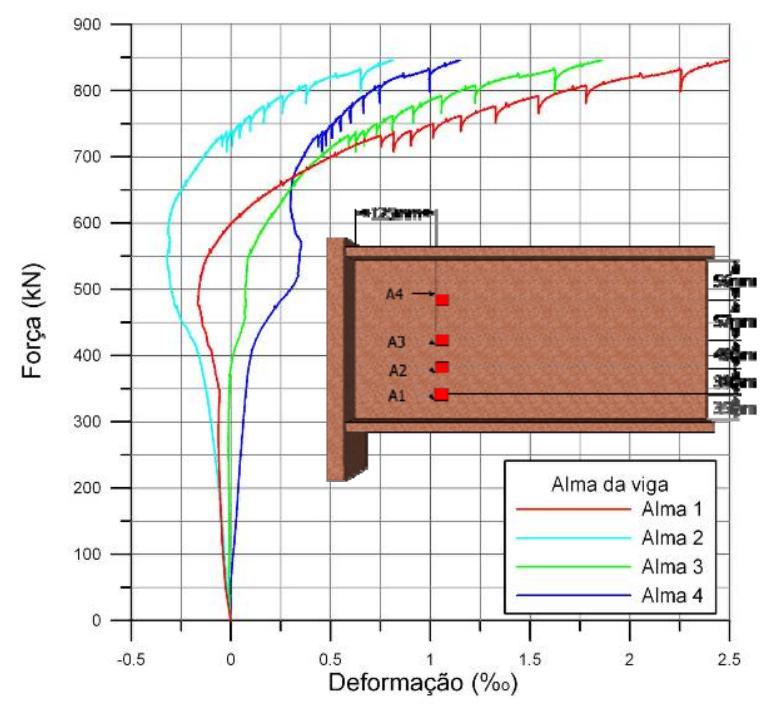

b) Deformações na alma

Figura 5-35 - Deformações na viga de aço - Modelo CC_AN.

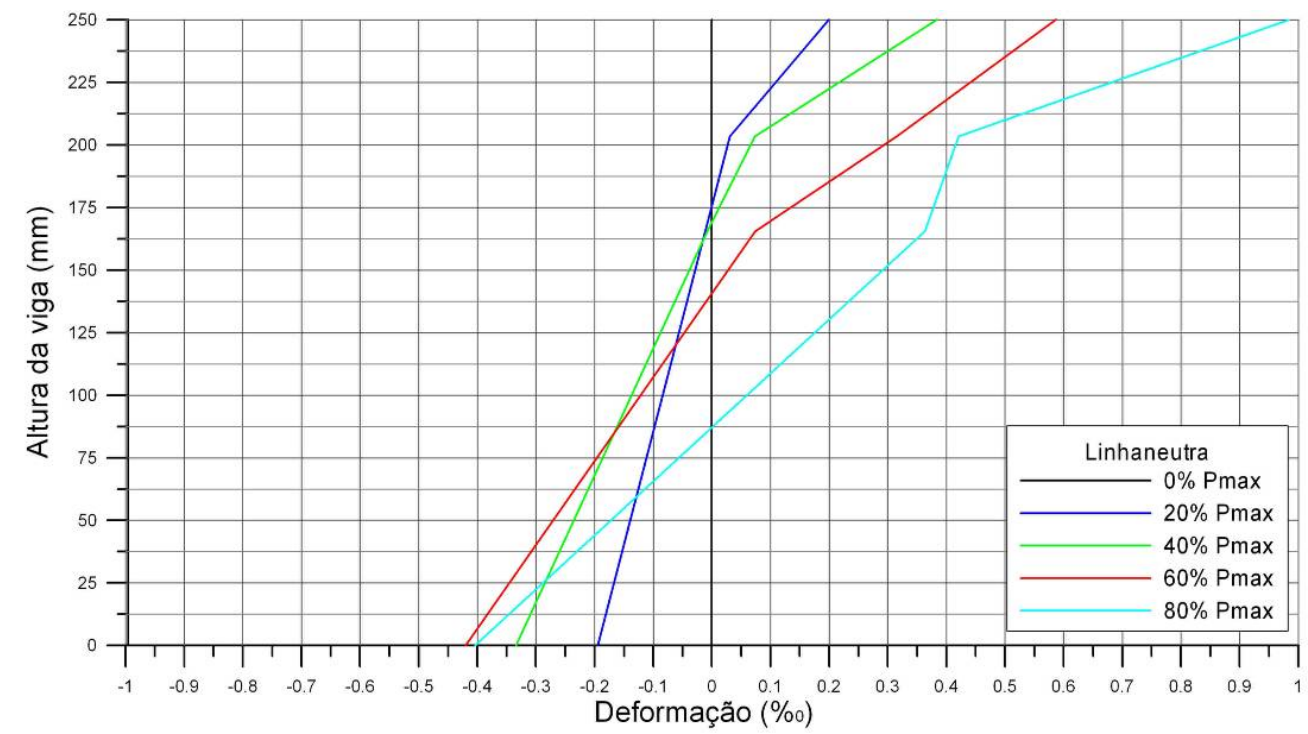

Figura 5-36 - Estimativa da linha neutra na viga de aço - Modelo CC_AN.

Da mesma forma que nos outros dois modelos, as leituras de deformação no perfil de aço e no núcleo de concreto do pilar foram utilizadas para avaliar a transferência de forças entre os dois materiais ao longo do pilar, para vários níveis de carregamento (Figura 5-37) 


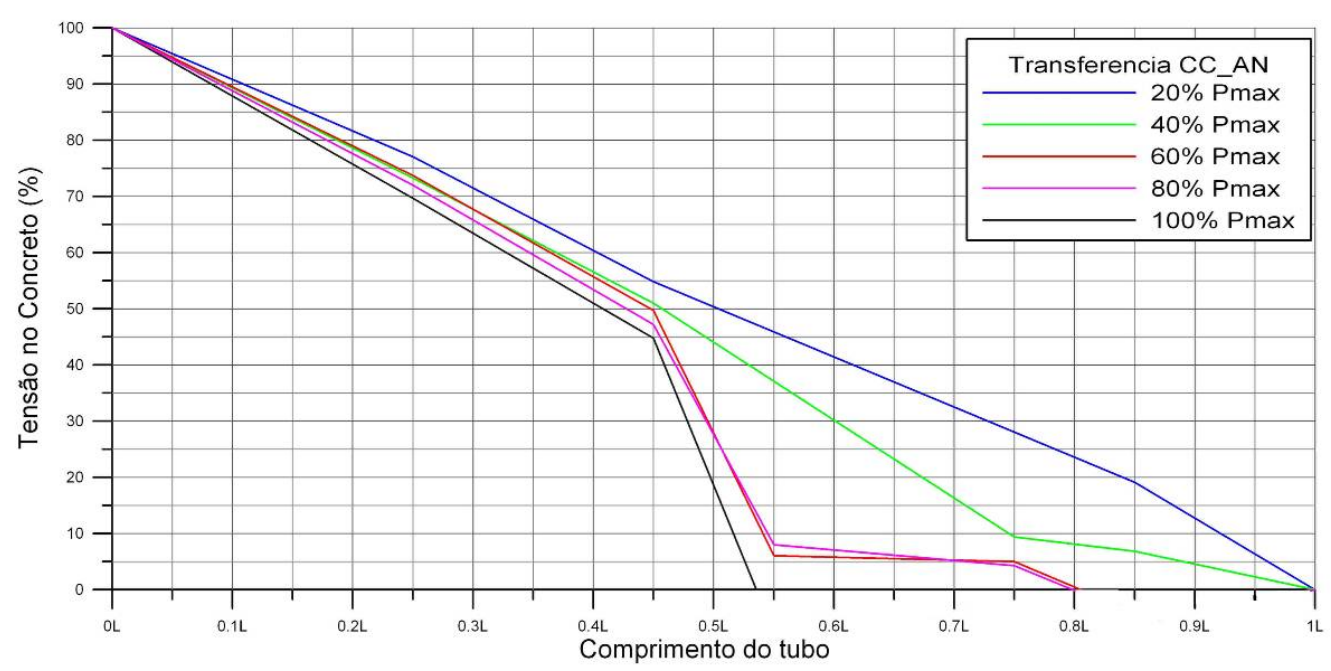

Figura 5-37 - Transferência de forças entre o concreto e o aço - Modelo CC_AN.

De acordo com os valores de transferência de forças entre os dois materiais no pilar misto, é possível perceber que o modelo com as cantoneiras atuando como conectores de cisalhamento é mais eficiente que os demais neste aspecto. Na fase inicial de carregamento até $40 \%$ da força última, as cantoneiras parecem não ter influência expressiva no comportamento mas, para valores superiores, grande parte da força aplicada é transferida do concreto para o aço, antes mesmo de atingir o inicio da ligação, ou seja, antes de atingir a meia altura do pilar. Quanto mais próximo da força última, mais eficiente é a transferência de forças entre concreto e aço.

\subsection{Análise comparativa dos resultados}

\subsubsection{Deformação no núcleo de concreto e no perfil de aço do pilar}

\section{preenchido}

As medidas de deformação no perfil de aço e no núcleo de concreto, ambos componentes do pilar preenchido, foram realizadas com o intuito de avaliar a transferência de 
forças entre os dois materiais e analisar a eficiência da aderência natural (no modelo CC_W) e dos conectores de cisalhamento para tal.

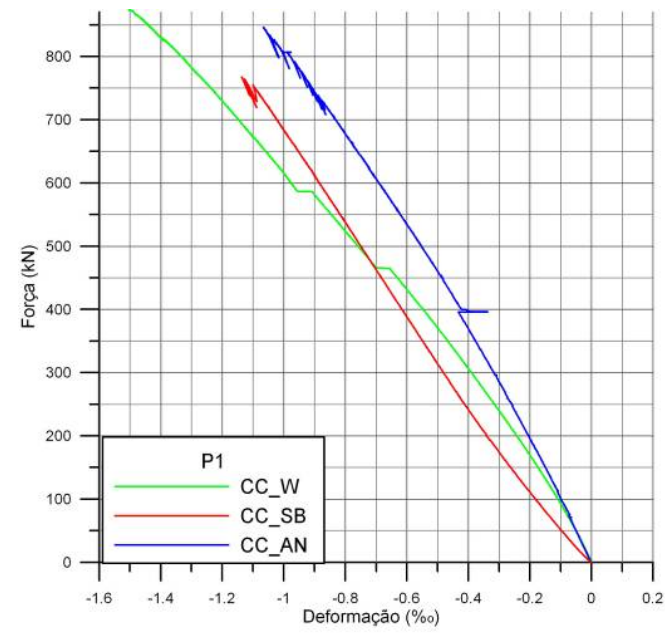

a) Deformação no ponto P1

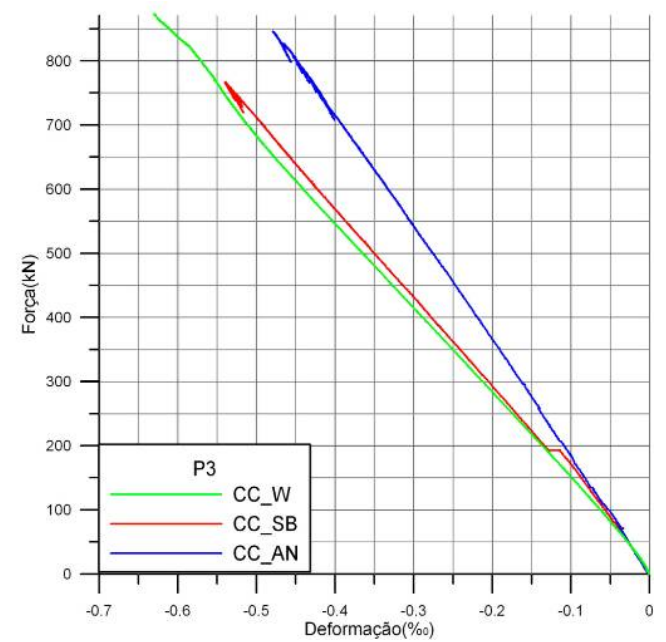

c) Deformação no ponto P3

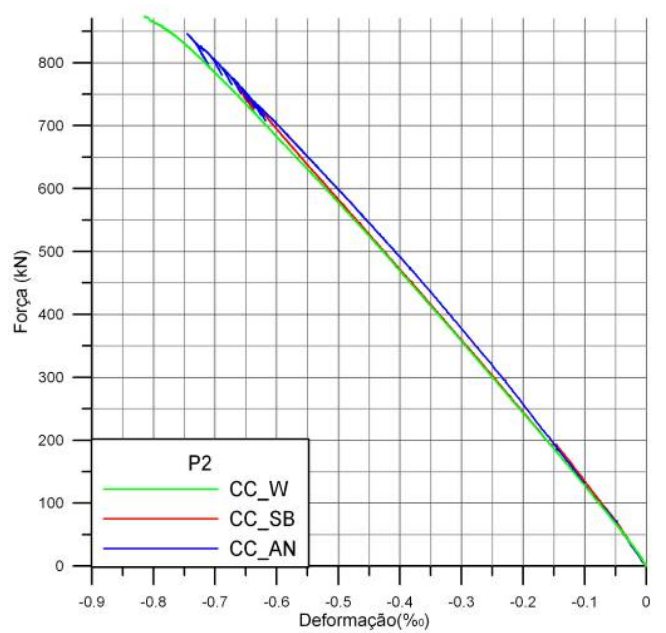

b) Deformação no ponto P2

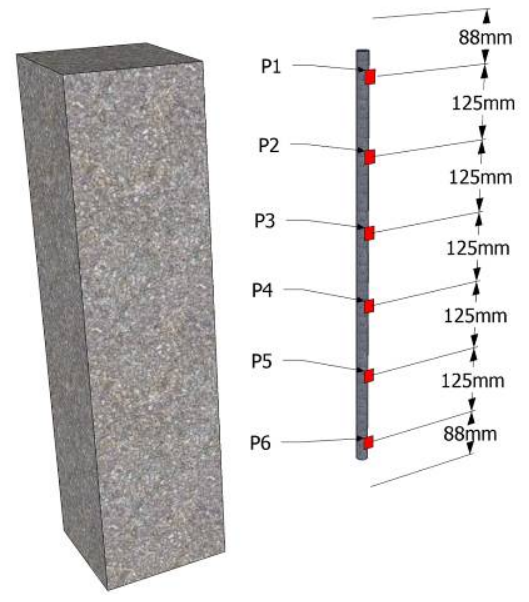

d) Pontos no núcleo de concreto

Figura 5-38 - Deformação axial no núcleo de concreto dos pilares mistos preenchidos.

Foram dispostos extensômetros ao longo de todo o comprimento do perfil e do núcleo de concreto. As leituras registradas no perfil na região da ligação com a viga foram descartadas, pois se acredita que o fato da região de ligação apresentar diversos tipos de solicitações ocasionou perturbações localizadas, comprometendo as leituras de deformação axial no perfil. A Figura 5-38 mostra a deformação do núcleo de concreto nos pontos P1, P2 e P3. As deformações nos pontos P4, P5 e P6 apresentaram valores muitos baixos porque, neste 
trecho, parte da força já foi transferida para a viga mista, desta forma não serão apresentados aqui.

A partir dos valores de deformação registrados no núcleo de concreto, conclui-se que o uso dos conectores de cisalhamento permite melhorar a transferência de forças entre os dois materiais, haja vista que nos modelos com conectores a deformação no concreto foi relativamente menor. Apesar de a deformação no concreto ser ligeiramente menor nos modelos com conectores, principalmente no modelo CC_AN (com cantoneiras), esta diferença não parece ser relevante para o comportamento do modelo, pois, além de ser pequena, esta diferença não modifica o modo de ruína do modelo.

Apesar do uso dos conectores não modificar o modo de falha do modelo, os conectores influenciam na transferência de tensões entre os dois materiais, principalmente para forças elevadas. Na Figura 5-39 é mostrada a transferência de forças nos três modelos ensaiados, para diferentes níveis de carregamento.

Os resultados expostos na Figura 5-39 indicam que o modelo CC_AN, que utiliza cantoneiras, apresenta melhor desempenho quanto à transferência de forças, principalmente nas etapas finais de carregamento. No entanto, este fator não indica melhor desempenho do modelo quanto à ruína, já que esta transferência de forças não é preponderante na definição do modo de falha do modelo. A alta variação das deformações no perfil não permitiu verificar, de forma eficaz, a contribuição dos conectores, apenas em alguns pontos foi permitido verificar a eficiência dos conectores, como ilustrado na Figura 5-40, onde é dada a deformação do perfil de aço nos pontos localizados logo abaixo dos conectores de cisalhamento. 

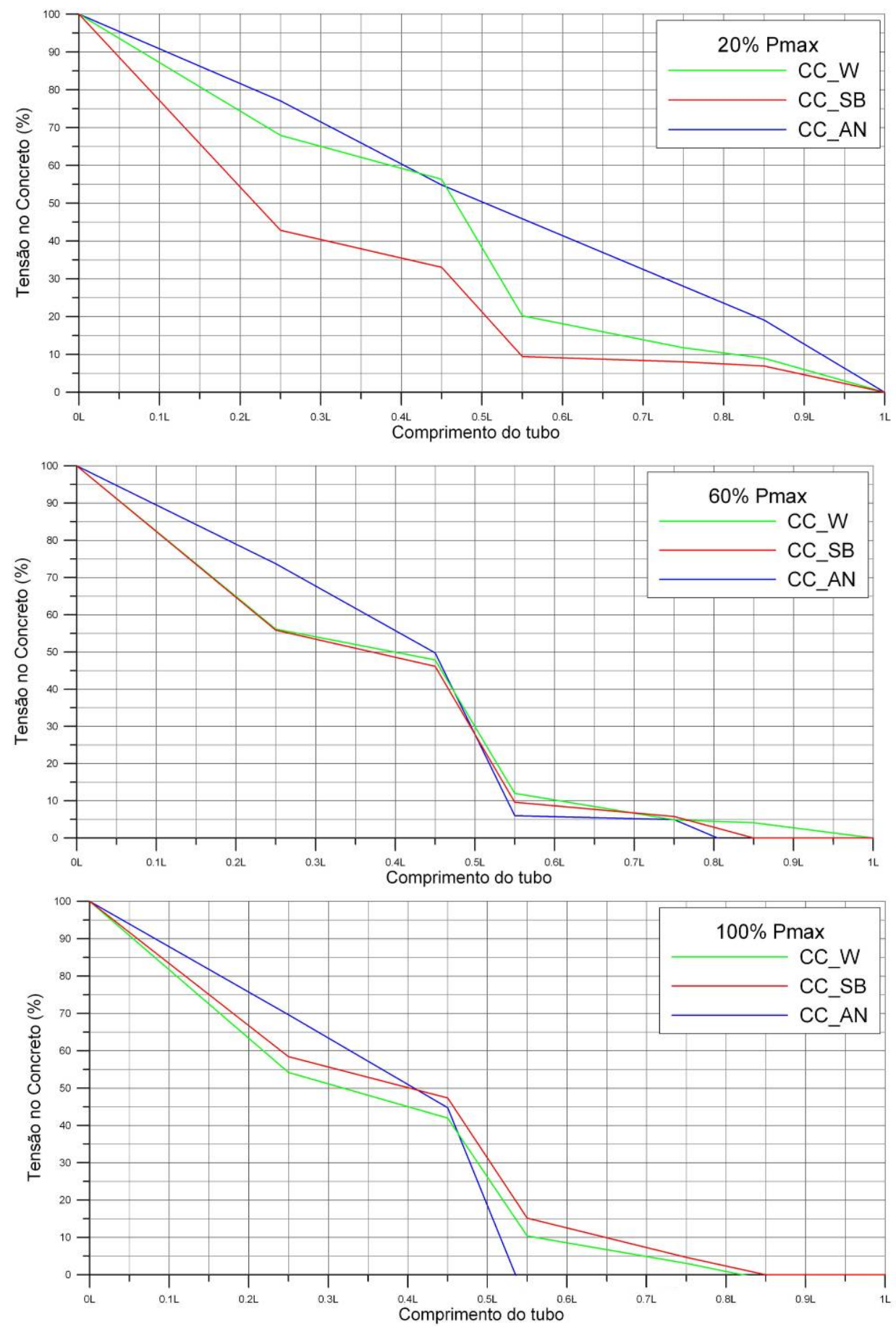

Figura 5-39 - Transferência de forças nos modelos ensaiados, para 20\%, $60 \%$ e $100 \%$ da força última. 


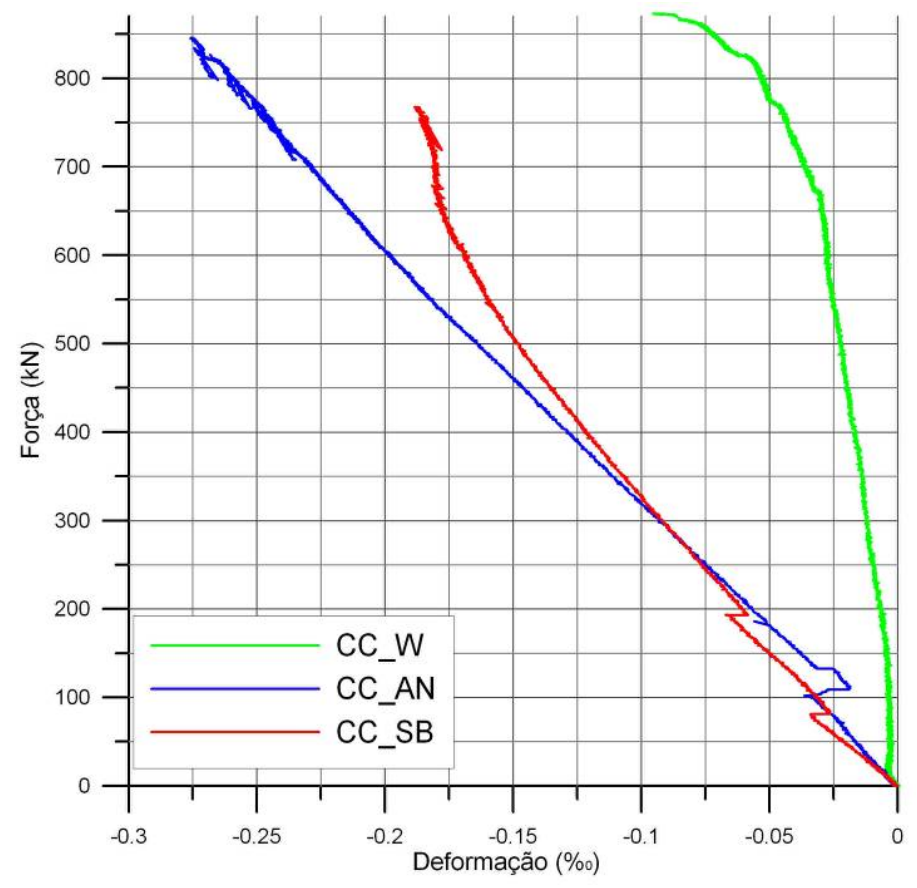

Figura 5-40 - Deformação medida no perfil abaixo do primeiro conector de cisalhamento

Se a concentração de tensões no perfil fosse o fator preponderante no modo de ruína do modelo, a transferência de força dos conectores e a aderência teriam maior relevância e o estudo desta transferência poderia fornecer resultados mais expressivos.

\subsection{Deformações na viga de aço}

O comportamento das deformações nas mesas e almas das vigas dos três modelos foi similar, com pequena variação de intensidade. Nos ensaios ficou evidente a ocorrência de uma deformação localizada nas mesas da viga, principalmente nas etapas finais de carregamento e nas proximidades da ligação da viga com o pilar. A Figura 5-41 mostra a deformação nas mesas da viga em um dos modelos ensaiados. 


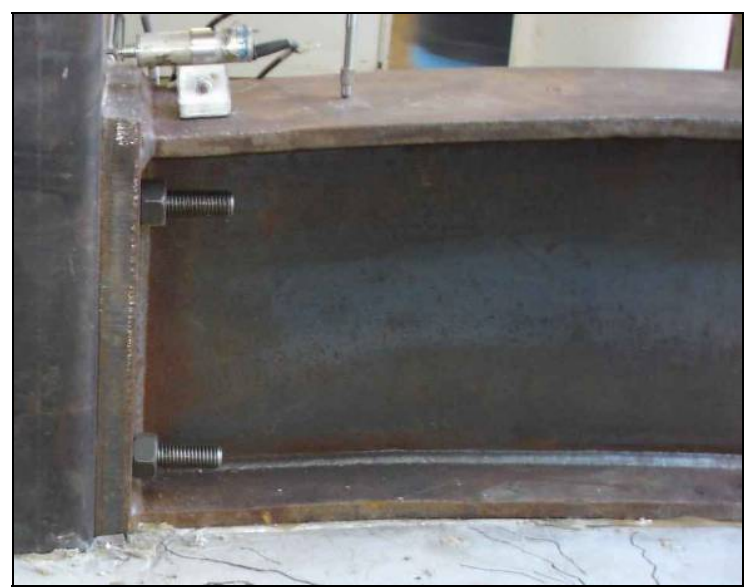

Figura 5-41 - Deformação localizada na mesa da viga de aço

Nota-se que a deformação nas mesas tem comportamento linear até atingir um pico e, neste ponto, ocorre redução das deformações. Acredita-se que efeitos localizados na flexão da viga de aço ocasionaram esta mudança de comportamento neste ponto. A Figura 5-42 apresenta a comparação das deformações das mesas comprimidas e tracionadas dos modelos físicos.

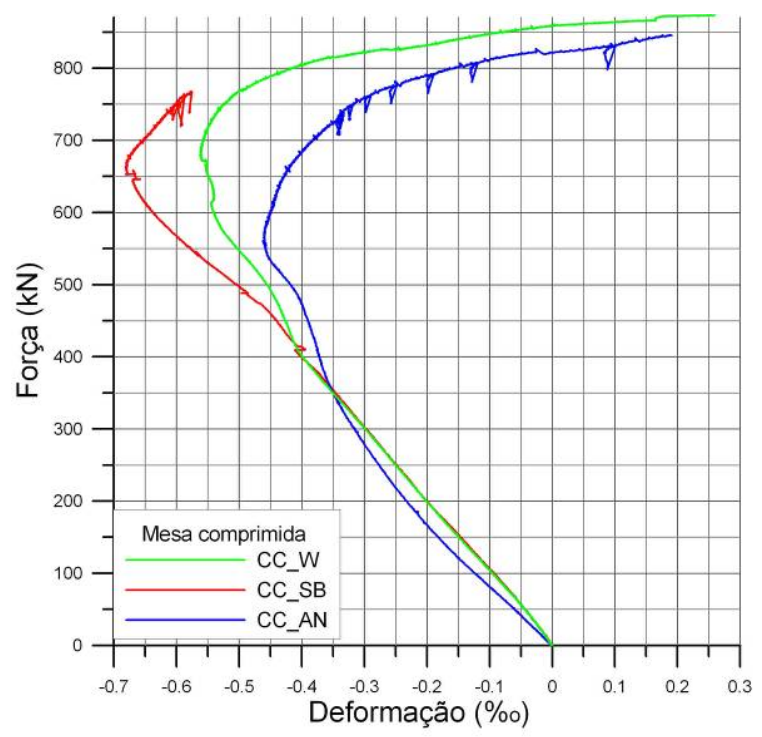

a) Deformação da mesa comprimida

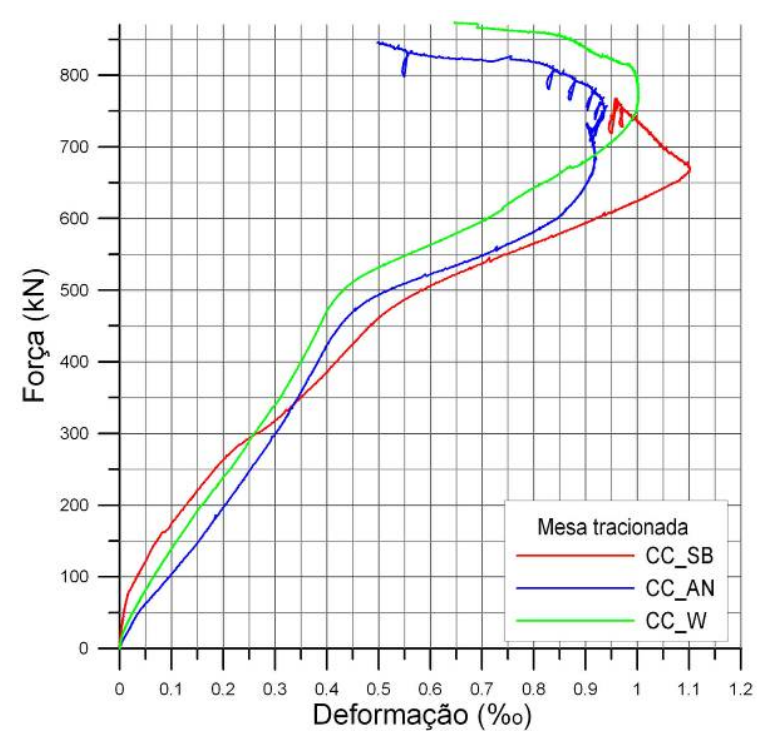

a) Deformação da mesa tracionada

Figura 5-42 - Deformações nas mesas das vigas de aço

Aparentemente, não há mudanças no comportamento das deformações nas mesas das vigas em função da presença de conectores ou cantoneiras no pilar preenchido, apenas na intensidade das deformações. A deformação nas mesas das vigas do modelo CC_SB foi mais 
intensa se comparada aos outros dois modelos. A redução das deformações nas mesas ocorreu, nos três modelos ensaiados, para forças entre $80 \%$ e $90 \%$ da força última.

Apesar da pouca diferença no comportamento das deformações na viga para os três modelos ensaiados, a análise da posição da linha neutra permitiu perceber que a distribuição da linha neutra nos modelos CC_SB e CC_AN pareceu mais adequada quando comparado ao modelo CC_W. No modelo CC_W, a ausência de qualquer tipo de conector prejudicou e reduziu a transferência de tensões entre os dois materiais, resultando em transferência inadequada de esforços do pilar misto para a viga de aço.

O comportamento das deformações na alma da viga foi similar nos três modelos, apenas com variação da intensidade e da linha neutra, que no modelo CC_W foi diferente dos demais. A Figura 5-43 mostra o comportamento das deformações nos quatro pontos instrumentados na alma das vigas.

O comportamento das deformações na região tracionada das vigas é praticamente idêntico nos três modelos; em contrapartida, para os pontos A1 e A2, localizados na região comprimida, o modelo CC_W apresenta maior deformação. Acredita-se que a ausência dos conectores de cisalhamento prejudica a transferência de esforços na região de ligação. Para os modelos ensaiados este fato não foi preponderante no modo de ruptura, embora isto não descarte a possibilidade de ruína por transferência de esforços inadequada em modelos com configurações geométricas diferentes. 


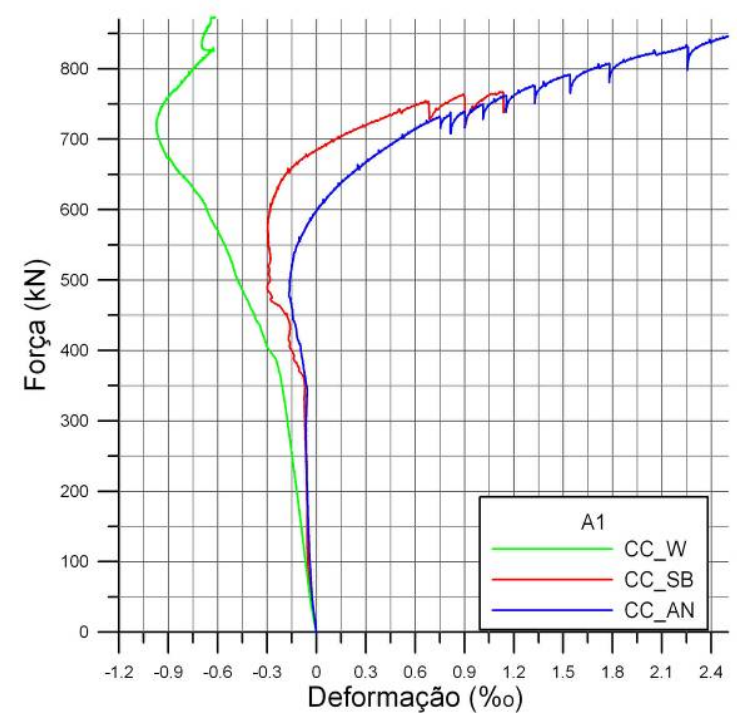

a) Deformação na Alma da viga - A1

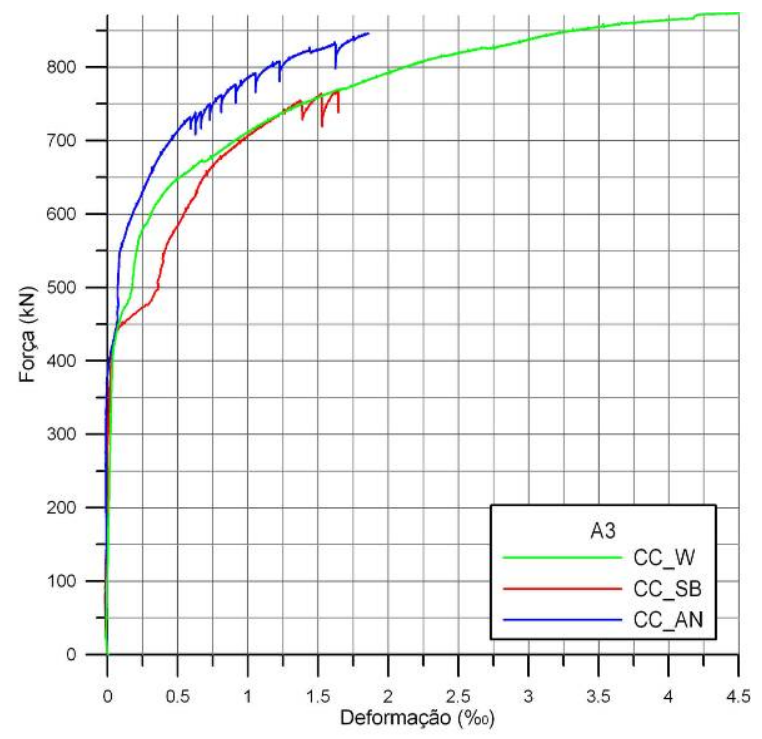

a) Deformação na Alma da viga - A3

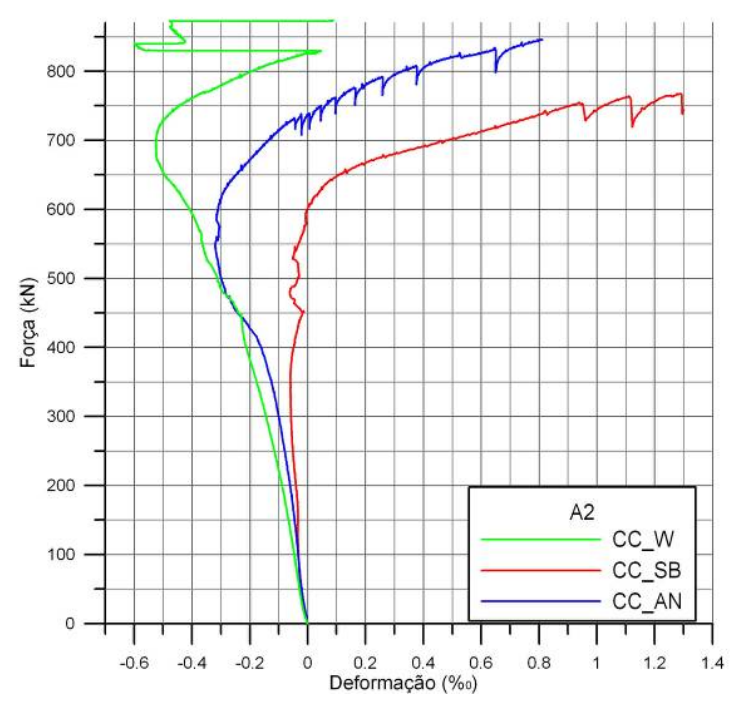

a) Deformação na Alma da viga - A2

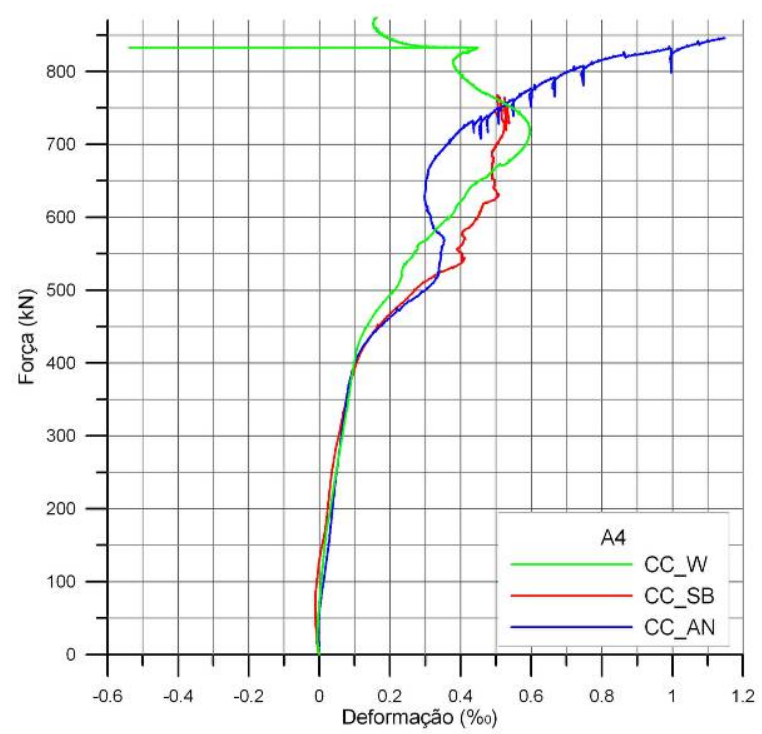

a) Deformação na Alma da viga - A4

Figura 5-43 - Deformações nas almas das vigas

\subsubsection{Deformações nas armaduras}

De acordo com os resultados obtidos experimentalmente, as armaduras da laje de concreto constituem o componente determinante para o comportamento da ligação mista. Nos três modelos ensaiados ocorreu o escoamento das armaduras localizadas nas bordas da laje. Após o escoamento das armaduras, não houve ganho de resistência, apenas acréscimo nos 
deslocamentos. Uma vez concluídos os ensaios, foi realizada a escarificação da laje de concreto para verificação da aparência das armaduras. Em nenhum dos modelos ocorreu ruptura de alguma barra de armadura. A Figura 5-44 mostra o comportamento das armaduras localizadas na borda das lajes dos três modelos ensaiados.

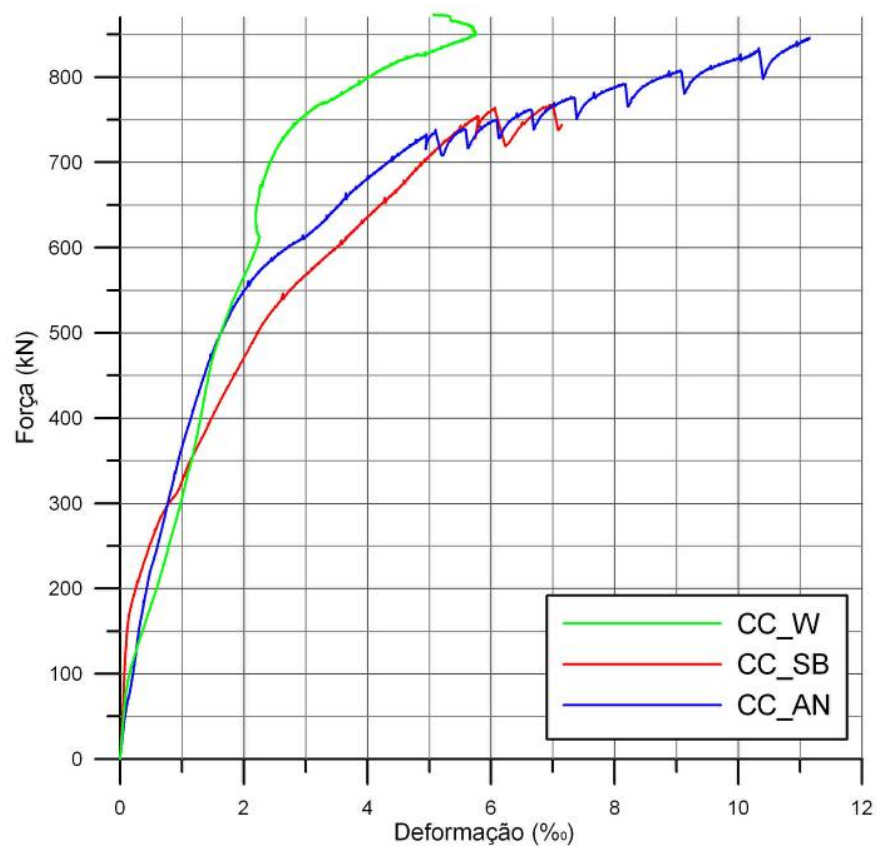

Figura 5-44 - Deformações das armaduras da borda da laje

No modelo CC_W, as armaduras apresentaram deformações menores que as registradas nos demais modelos. Com a análise da posição da linha neutra realizada anteriormente, foi verificado que no modelo CC_W a linha neutra se localiza abaixo da posição observada para os demais modelos. Isto indica que as armaduras do referido modelo são menos solicitadas porque o braço de alavanca é menor.

As armaduras localizadas na região central do modelo foram pouco solicitadas. Uma alternativa para a mobilização das armaduras deste neste trecho é melhorar as condições de ancoragem destas armaduras. 


\subsection{Comparações com SILVA (2006)}

Um dos objetivos do trabalho foi analisar a influência da inclusão da laje no comportamento da ligação a partir da comparação dos resultados com aqueles obtidos por SILVA (2006), já que o modelo de ligação analisado por ele foi idêntico ao aqui apresentado, diferindo apenas na ausência de laje de concreto armado na ligação.

Acreditava-se inicialmente que a inclusão da laje poderia aumentar a capacidade resistente e melhorar o comportamento da ligação quanto à rigidez e ao modo de ruptura, já que no modelo de SILVA (2006) a ruptura ocorreu de forma inadequada, pela ruptura dos parafusos da ligação metálica.

A Figura 5-45 mostra a curva força aplicada e deslocamento do modelo CC_W, confrontando com o modelo experimental BCFT_S de SILVA (2006).

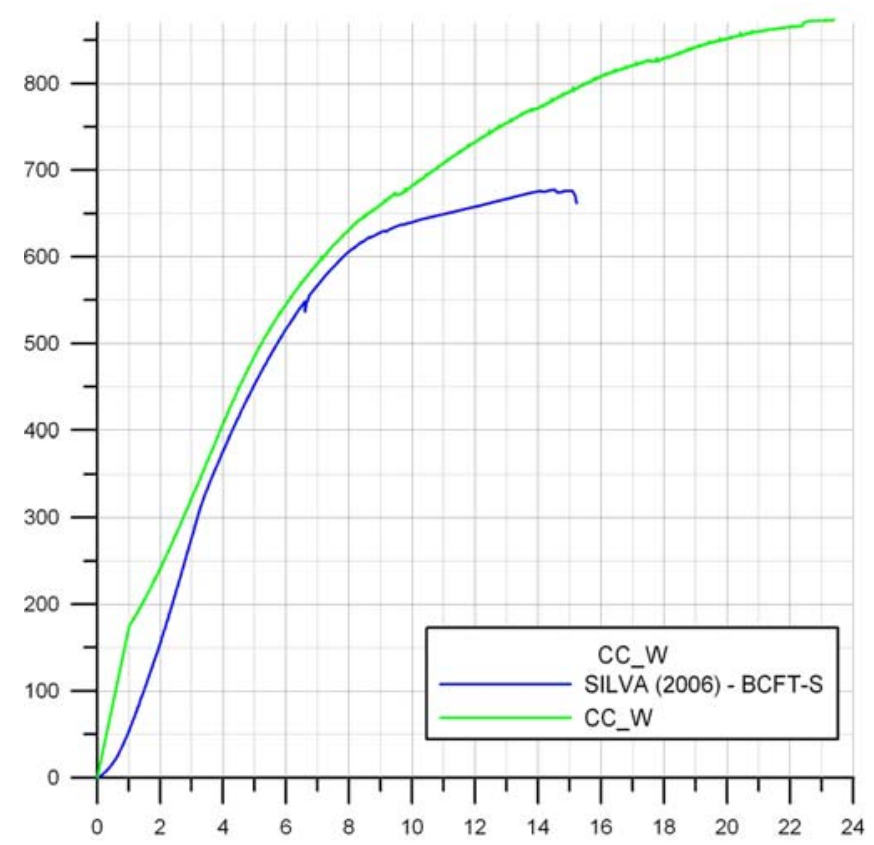

Figura 5-45 - Comparações entre o modelo CC_W e BCFT_S de SILVA (2006)

A inclusão da laje adicionou resistência ao modelo sem conectores de cisalhamento. O modelo BCFT-S apresentou uma resistência bastante inferior ao modelo CC_W, devido provavelmente à inclusão de laje no modelo. Para os modelos restantes, a diferença entre os 
valores de resistência não foram tão significativas. A Figura 5-46 ilustra a comparações entre os modelos CC_SB e BCFT_SB de SILVA (2006), sendo estes modelos com conectores de cisalhamento do tipo pino com cabeça.

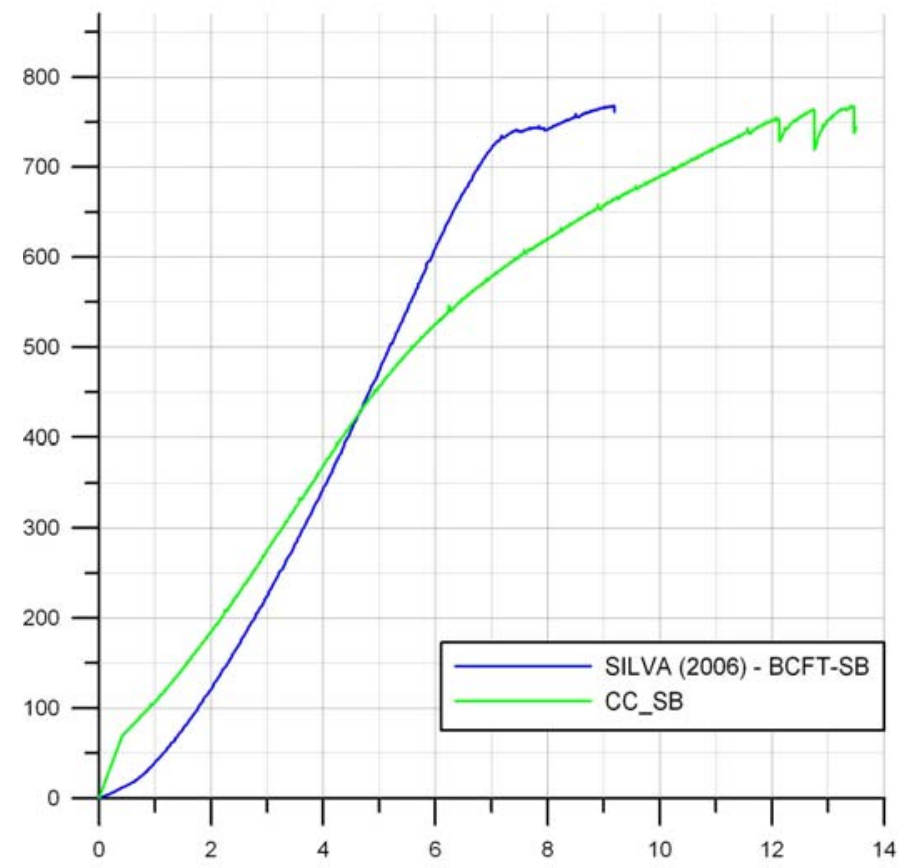

Figura 5-46 - Comparações entre o modelo CC_SB e BCFT_SB de SILVA (2006)

Os resultados para estes modelos indicam que não houve mudança brusca na resistência do modelo, mas sim uma mudança na rigidez. O comportamento do modelo com a laje de concreto se apresenta mais dúctil. Outro aspecto positivo diz respeito à forma da ruptura do modelo, atingida por deformação excessiva da armadura, ao contrário do ocorrido nos modelos estudados por SILVA (2006). Para o modelo com cantoneiras o comportamento do deslocamento perante a força aplicada, bem como a comparação dos resultados, pode ser observado na Figura 5-47. 


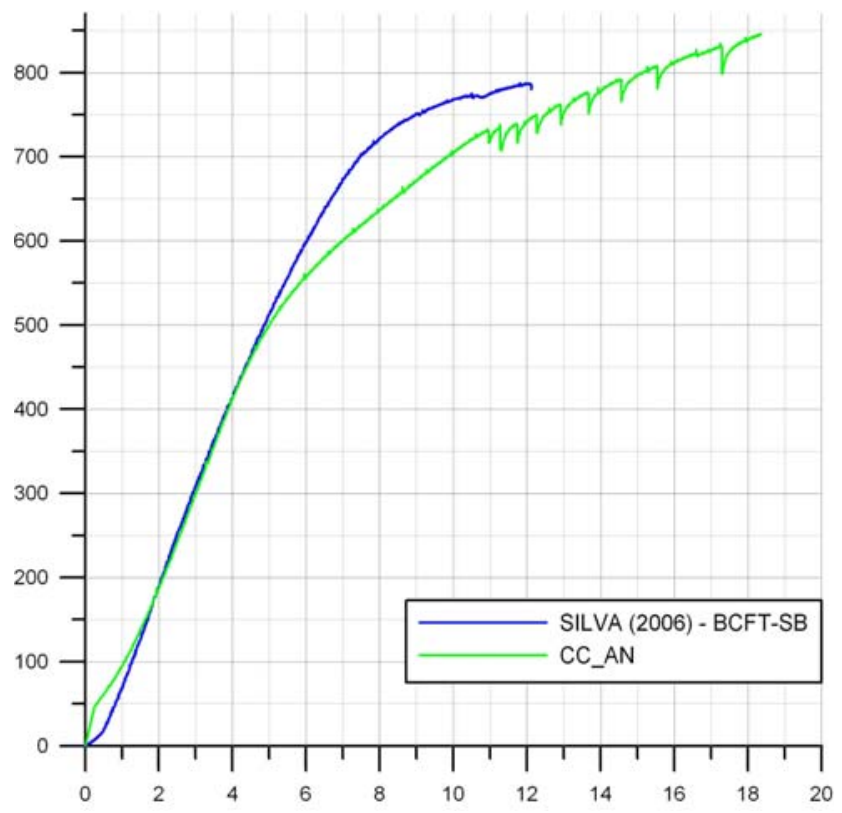

Figura 5-47 - Comparações entre o modelo CC_AN e BCFT_A de SILVA (2006)

Da mesma forma que no modelo apresentado anteriormente, os modelos CC_AN e BCFT_AN não apresentaram quanto à resistência uma diferença tão significativa, mas o modelo com a laje de concreto apresentou um comportamento superior.

$\mathrm{Na}$ análise dos três modelos, apenas o modelo sem a presença de conectores apresentou diferença de resistência, quando comparado os modelo com e sem a presença da laje de concreto. Mas na comparação dos três modelos, a rigidez e a ductilidade são superiores nos modelos com a presença da laje. Vale salientar que o modo de ruptura nos modelos com a laje de concreto foi mais adequado, com a deformação excessiva das armaduras, já que nos modelos de SILVA (2006) a ruptura ocorreu de forma brusca nos parafusos da ligação.

\subsection{Comentários finais}

A partir dos resultados oriundos da investigação experimental, algumas considerações merecem destaque: 
- A presença da laje de concreto armado é determinante para o comportamento da ligação, principalmente no que se refere à capacidade de transmitir momento fletor. Portanto, as armaduras da laje constituem o componente principal da ligação e determinam o comportamento da ligação mista, tanto na resistência como na rigidez.

- Os conectores de cisalhamento apresentam importância quanto à capacidade de transferência de força entre o concreto e o aço do pilar misto.

- A presença dos conectores e o tipo de conector não teve influência significativa na resistência ou no modo de ruína da ligação mista, pois o que fator predominante para a ruptura foi a armadura da laje. Provavelmente, em um modelo com maior taxa de armadura os conectores poderiam ser determinantes, permitindo a ruptura da interface aço-concreto do pilar preenchido antes do escoamento das armaduras da laje (ruptura no pilar misto), o que seria de qualquer modo indesejável.

- Os conectores de cisalhamento influenciaram na transferência de esforços do pilar misto para a ligação, já que o modelo CC_W (sem conectores) apresentou comportamento diferente quanto à posição da linha neutra.

- A comparação entre os modelos experimentais e os modelos estudados anteriormente em SILVA (2006) permitem concluir que a presença da laje pode acrescentar resistência à ligação, além de permitir um modo de ruptura adequado. 


\section{Capítulo 6}

\section{Análise numérica}

\subsection{Apresentação}

É apresentado, neste capítulo, todo o desenvolvimento da análise numérica. Para tal fim, foi utilizado o método dos elementos finitos e o pacote computacional DIANA.

Inicialmente, é feita a apresentação do problema específico da ligação estudada e da estratégia utilizada para a sua representação numérica e posterior análise. Foram feitos testes iniciais a fim de calibrar o modelo numérico e facilitar a compreensão do comportamento. Algumas das principais características deste modelo inicial são apresentadas e discutidas.

Também constam, no decorrer do capítulo, alguns detalhes dos elementos finitos e dos modelos constitutivos utilizados, dando atenção especial ao modelo constitutivo do concreto. O modelo numérico denominado final e utilizado para a análise numérica é, então, avaliado mediante comparações com os resultados advindos do modelo experimental.

\subsection{Modelo inicial}

Na modelagem numérica foi definido, como passo inicial, o desenvolvimento de um modelo plano simples para o pilar misto preenchido, com o intuito de verificar o comportamento da aderência aço-concreto no pilar.

Para a modelagem da aderência foi utilizado um elemento de interface entre os dois materiais, caracterizando a transferência de tensões e o deslizamento relativo por meio de 
curvas "bond-slip". Este procedimento é utilizado com mais freqüência em análises de aderência entre barras de aço e concreto, como em SPACONE (2001) e NETO (2007).

Este procedimento também pode ser encontrado em alguns trabalhos na área de estruturas mistas de aço e concreto onde, por meio de ensaios do tipo "push-out”, é possível obter o comportamento da interface, implementando esta propriedade em análises posteriores, como em JEONG, KIM e AHN (2005).

Esse tipo de análise se mostrou superior em desempenho computacional quando comparada ao uso de elementos de contato utilizando o modelo de atrito de Mohr, mas deve ser utilizada apenas para problemas específicos. Desta forma, como estratégia inicial, foram implementados modelos de pilares mistos preenchidos submetidos a cisalhamento direto, para observar o comportamento da aderência entre aço e concreto. Dois tipos de modelagem foram utilizados: um modelo plano e um modelo tridimensional com elementos sólidos. A Figura 6-1 mostra os modelos iniciais analisados.

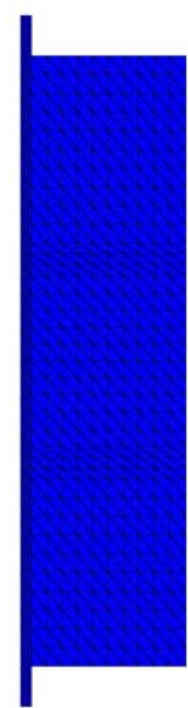

a) Modelo plano do pilar misto

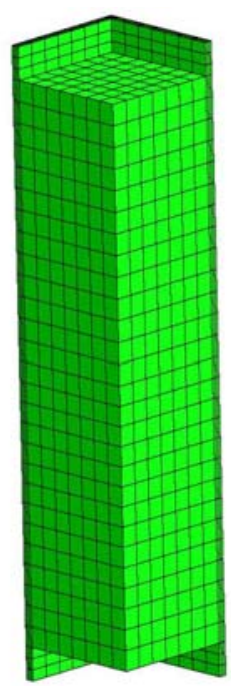

b) Modelo de pilar misto com elementos sólidos

Figura 6-1 - Modelos iniciais de elementos finitos 
Os resultados obtidos com estes modelos foram confrontados com os resultados experimentais de SILVA (2006), que realizou ensaios do tipo "push-out” em pilares mistos preenchidos.

Estas análises foram utilizadas para aferir a curva numérica que caracteriza a transferência de tensões entre o aço e concreto no pilar preenchido, possibilitando seu uso posterior no modelo numérico final da ligação.

Para todos os modelos foi utilizado plano de simetria, ou seja, apenas $1 / 4$ do modelo foi modelado e analisado. Isto possibilitou a diminuição do custo computacional e do tempo de processamento. Tanto o modelo plano quanto o modelo sólido apresentaram resultados satisfatórios quanto à transferência de tensões. Embora os resultados referentes às deformações nos componentes não tenham sido satisfatórios, foi decidido permanecer com o modelo de deslizamento obtido para as análises posteriores. Os modelos iniciais possibilitaram a criação de um modelo mais completo e coerente para a resolução do problema analisado. O modelo final será apresentado posteriormente.

\subsection{Elementos finitos}

Nesta seção serão apresentados detalhes a respeitos dos elementos finitos utilizados na análise numérica e que fazem parte da biblioteca de elementos do software DIANA. Na análise numérica foram utilizados elementos sólidos, elementos de casca, de viga e elementos de interface.

Para a modelagem da laje de concreto, do núcleo de concreto e da chapa de extremidade foi utilizado o elemento sólido HX24L, que é um elemento finito isoparamétrico, de 8 nós, com aproximação linear para os deslocamentos. 
Os elementos sólidos geralmente apresentam um alto custo computacional devido ao tamanho da matriz de rigidez e da necessidade de um bom refinamento da malha para obter soluções adequadas, devendo ser utilizados apenas onde não é possível utilizar elementos menos robustos. Os elementos sólidos apresentam apenas deslocamentos como graus de liberdade nos nós. A Figura 6-2 apresenta o elemento HX24L, seus graus de liberdade e a função aproximadora para os deslocamentos.

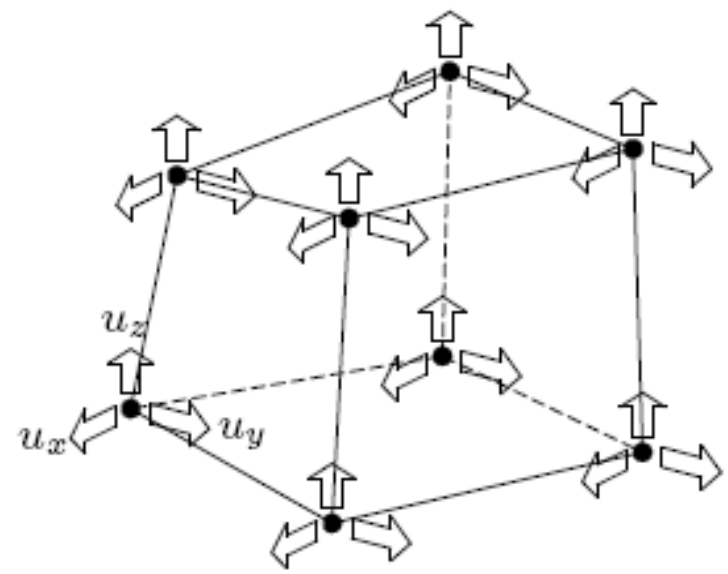

a) Graus de liberdade nodais

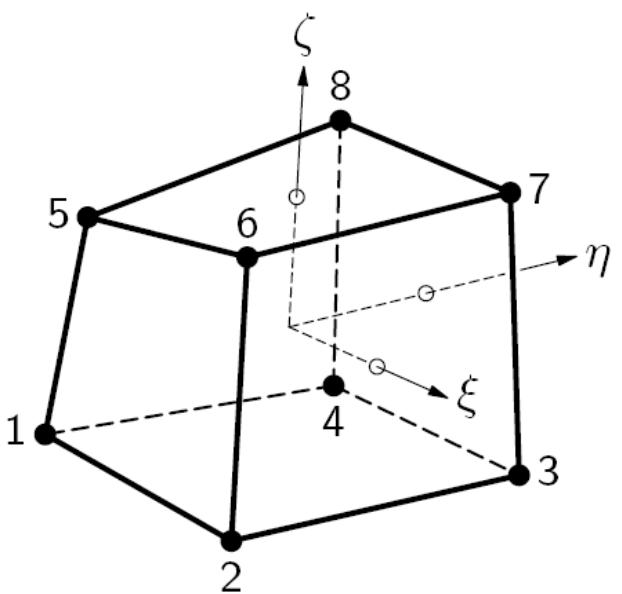

b) Elemento HX24L

$$
u_{i}(\xi, \eta, \zeta)=a_{0}+a_{1} \xi+a_{2} \eta+a_{3} \zeta+a_{4} \xi \eta+a_{5} \eta \zeta+a_{6} \zeta \xi+a_{7} \xi \eta \zeta
$$

c) Função aproximadora dos deslocamentos para o elemento HX24L

Figura 6-2 - Detalhes dos elementos HX24L

A partir das derivadas nos pontos de integração do elemento finito e conhecendo os deslocamentos nodais, podem ser obtidas as deformações de Green-Lagrange. As tensões de Cauchy também são obtidas nos pontos de integração do elemento finito.

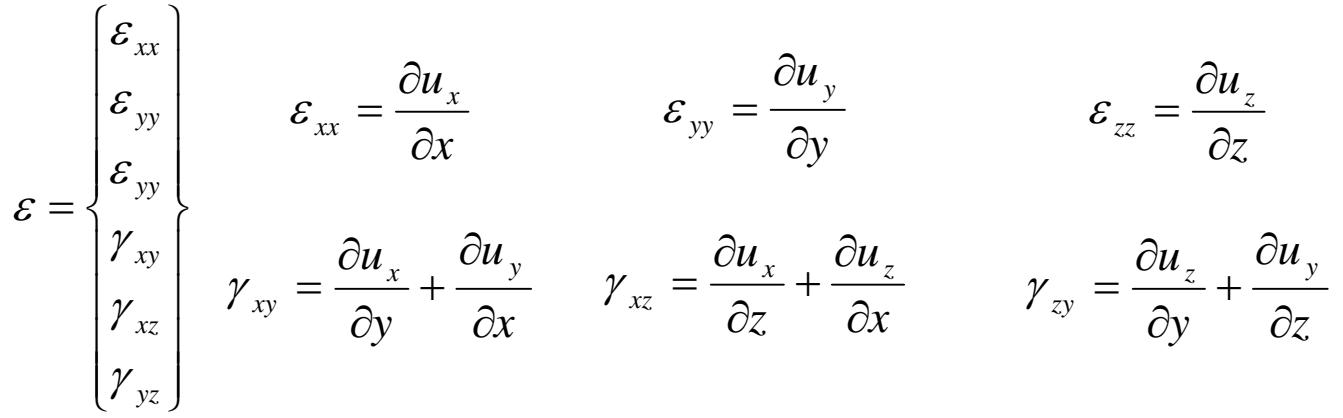




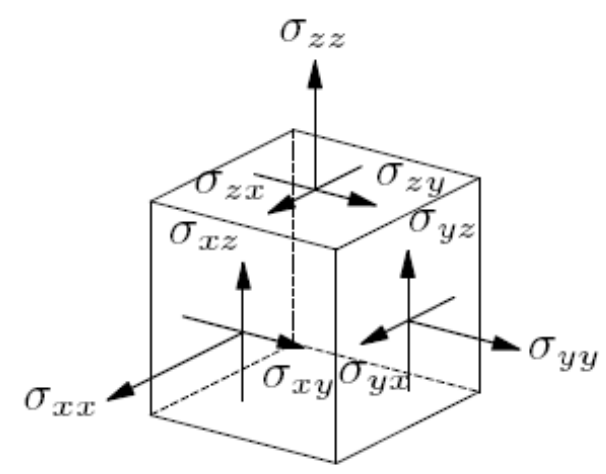

a) Tensões de Cauchy
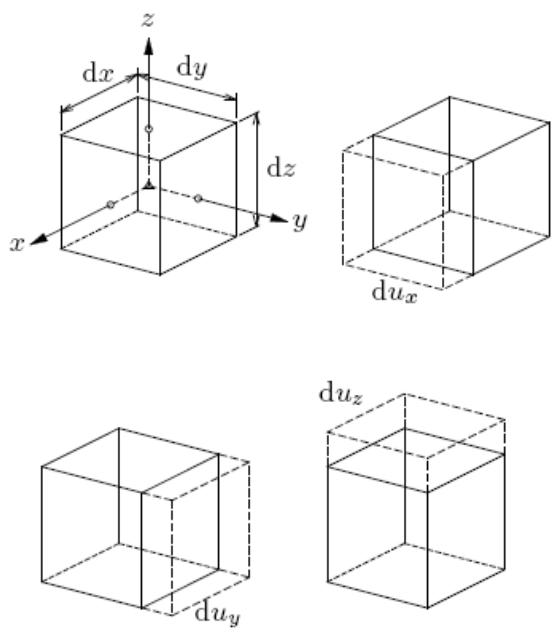

b) Deformação

Figura 6-3 - Detalhes referentes ao elemento sólido

Para a modelagem do perfil de aço do pilar misto e da viga metálica foi utilizado o elemento de casca Q20SF, da biblioteca de elementos finitos do software DIANA. Tal elemento de casca tem aproximação linear para os deslocamentos e 4 nós. O elemento de casca é a combinação de um elemento finito de chapa (estado plano de tensões) com um elemento de placa (Figura 6-4). A formulação utilizada no comportamento de placa do elemento de casca é a da teoria de Mindlin-Reissner. Os graus de liberdade nodais neste elemento finito de casca são os deslocamentos nas três direções e a rotação no plano do elemento, como indicado na Figura 6-5, onde também são indicados graus de liberdade do elemento de casca, descrição do elemento Q20SF e a sua função aproximadora.

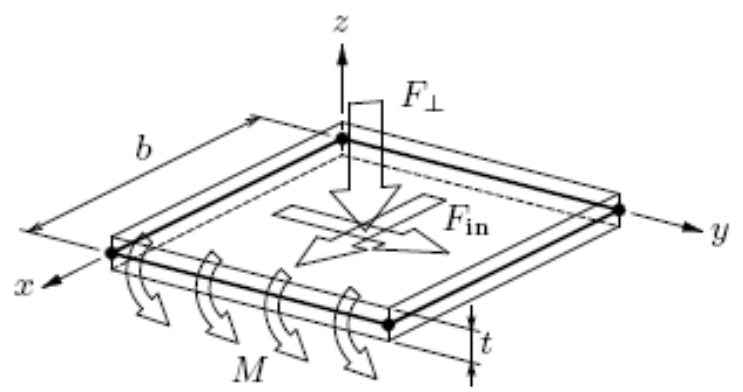

Figura 6-4 - Descrição do elemento de casca 


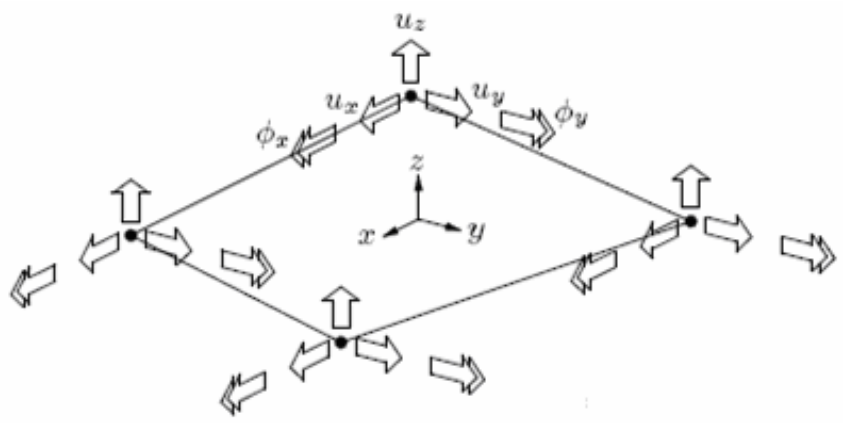

a) graus de liberdades nodais

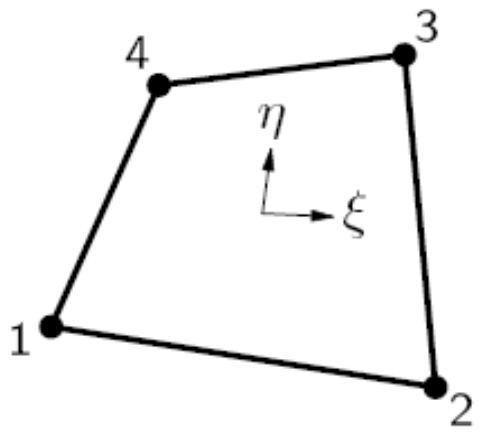

b) Elemento Q20SF

$$
\begin{aligned}
& u_{i}(\xi, \eta)=a_{0}+a_{1} \xi+a_{2} \eta+a_{3} \xi \eta \\
& \phi_{i}(\xi, \eta)=b_{0}+b_{1} \xi+b_{2} \eta+b_{3} \xi \eta
\end{aligned}
$$

c) Função aproximadora dos deslocamentos e da rotação do elemento Q20SF

Figura 6-5 - Detalhes do elemento Q20SF

As deformações no elemento finito são obtidas empregando a equação (6.2), sendo que, na Figura 6-6 é apresentada a convenção de sinais para as deformações no elemento finito. As tensões presentes no elemento finito de casca, calculadas pelo software DIANA, são as tensões de Cauchy, momentos e forças, apresentados na Figura 6-6..

$$
\varepsilon=\left\{\begin{array}{c}
\varepsilon_{x x} \\
\varepsilon_{y y} \\
\varepsilon_{y y} \\
\gamma_{x y} \\
k_{x x} \\
k_{y y} \\
k_{x y} \\
\Psi_{y z} \\
\Psi_{x z}
\end{array}\right\} \quad \varepsilon_{x x}=\frac{\partial u_{x}}{\partial x} \quad \varepsilon_{y x}=\frac{\partial u_{y}}{\partial y} \quad \varepsilon_{z z}=\frac{v\left(\varepsilon_{x x}+\varepsilon_{y y}\right)}{1-v}
$$




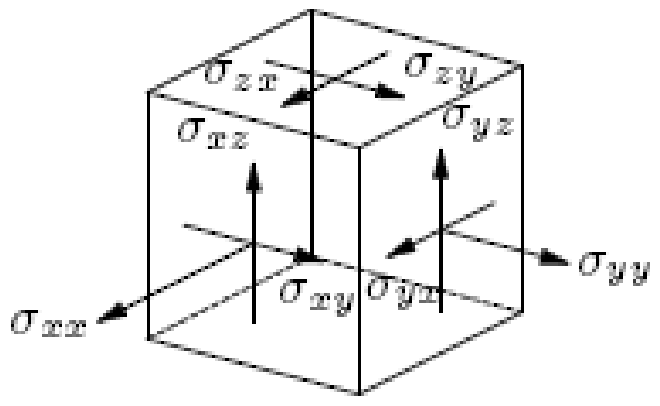

a) Tensões de Cauchy
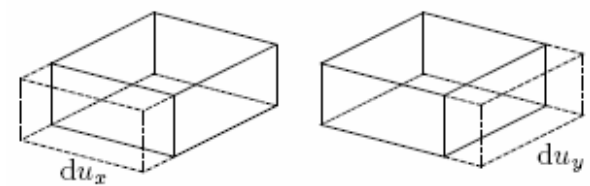
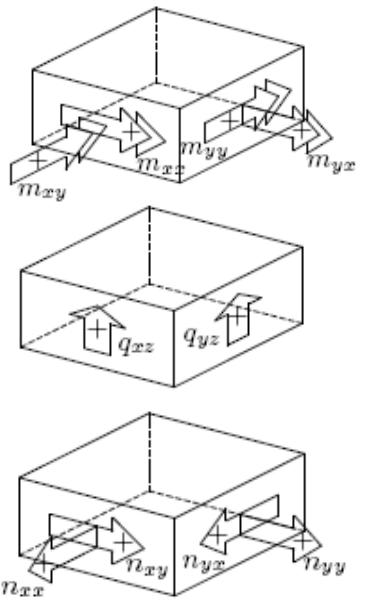

b) Convenção dos esforços

c) Deformações do elemento finito

Figura 6-6 - Convenção adotado pelo DIANA das deformações e tensões

Os elementos de interface são capazes de representar o comportamento de uma interface relacionando tensão normal e tensão de cisalhamento na interface com o deslizamento relativo nas duas direções. Outras não-linearidades são possíveis de representar com os elementos de interface, como a inclusão do atrito de Mohr-Coloumb e o comportamento “bond-slip”. A Figura 6-7 mostra os graus de liberdade do elemento de interface. O elemento de interface utilizado foi o Q24IF, elemento que representa a interface entre dois planos em uma configuração tridimensional. O elemento Q24IF tem 8 nós, sua representação encontra-se na Figura 6-8. 


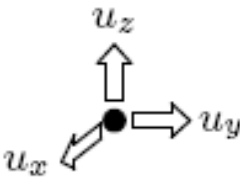

$$
\mathbf{u}_{e}=\left\{\begin{array}{l}
u_{x} \\
u_{y} \\
u_{z}
\end{array}\right\}
$$

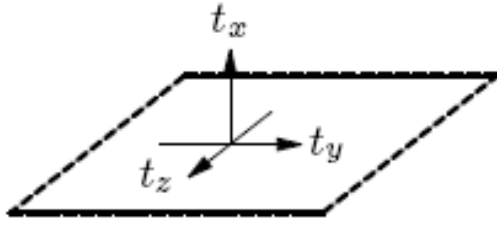

$\mathbf{t}=\left\{\begin{array}{l}t_{x} \\ t_{y} \\ t_{z}\end{array}\right\}$

Figura 6-7 - Graus de liberdade no elemento de interface
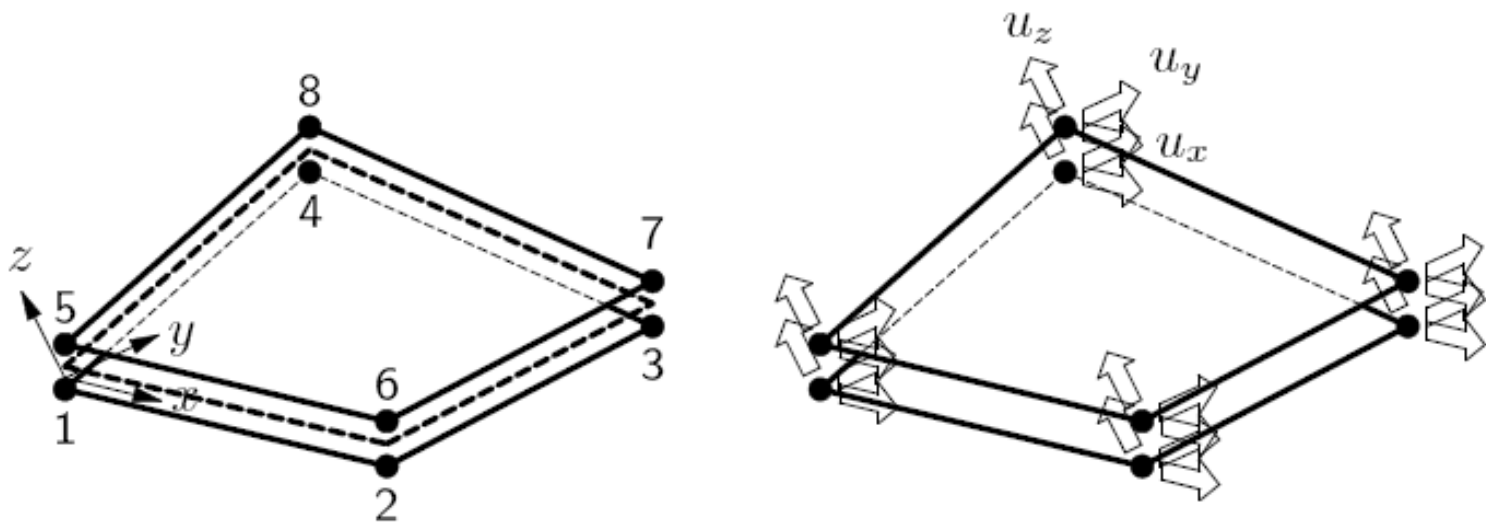

Figura 6-8 - Detalhes do elemento Q24IF

Para a modelagem dos parafusos da ligação foi utilizada uma simplificação que consistiu na inclusão de elementos de viga na região correspondente aos parafusos, ligando a viga metálica ao pilar misto. Na região de contato entre a chapa de extremidade e o tubo de aço inicialmente foram utilizados elementos de contato. Posteriormente, ao longo das análises percebeu-se que a não inclusão destes elementos não ocasionava prejuízos aos resultados e permitia a simplificação do modelo.

O software DIANA possui elementos que permitem simular o comportamento das armaduras. Os elementos de armadura (Embedded reinforcements) não possuem nós e funcionam como enrijecedores dos elementos finitos aos quais estão conectados (comumente chamados de "mother elements"). Desta forma, estes elementos não possuem graus de liberdade e seu comportamento é habilitado na direção axial da armadura. A aderência entre a armadura e o concreto é considerada perfeita, apenas com a inclusão de elementos de 
interface para simular a aderência não perfeita. É possível a inclusão de não-linearidades no comportamento das armaduras como encruamento e plastificação do aço.

\subsection{Modelos constitutivos}

Para o aço foi utilizado como modelo constitutivo o modelo elasto-plástico perfeito com o critério de plastificação de Von-Misses.

Para o concreto o modelo constitutivo utilizado é denominado pelo software Diana “Total Strain Crack Model”. Este modelo constitutivo foi originalmente proposto por Vecchio \& Collins (1986) e a sua formulação tridimensional foi apresentada pela primeira vez em Selby \& Vecchio (1993). Dois modelos constitutivos são possíveis de serem utilizados para o concreto: o modelo “Total Strain Fixed Crack” e o “Total Strain Rotate Crack”.

Tanto na tração como na compressão o concreto apresenta redução da capacidade de carga com o acréscimo da deformação após atingir o valor de pico, fenômeno conhecido como amolecimento ou "strain-softening”. Este efeito de amolecimento ocorre em uma região localizada. O software DIANA utiliza a teoria da mecânica da fratura nos modelos de fissuração do concreto para considerar isto.

Neste caso, o software utiliza dois tipos de modelos: o modelo de fissuração discreta e o modelo de fissuração distribuída. O “Total Strain Crack Model” se trata de um modelo de fissuração distribuída, onde os parâmetros são: a energia de fraturamento, o comprimento equivalente e a largura de banda da fissura. Os modelos com fissuração discreta têm a necessidade da mudança da malha a cada ocorrência de danificação de um elemento finito, impossibilitando que aquele local participe do meio contínuo do domínio do problema. Para o modelo de fissuração distribuída, o elemento danificado permanece como um meio contínuo, 
integrando o domínio com as respectivas relações tensão-deformação, sem a necessidade da mudança da malha a cada passo de carga aplicado.

A diferença entre os modelos “Fixed Crack" e o "Rotate Crack” está relacionada apenas com a propagação das fissuras. No modelo "Rotate Crack" é permitida a mudança da direção da fissura durante sua propagação, enquanto para “Fixed Crack” isto não é possível, ocorrendo apenas para uma variação do ângulo de 90 graus.

O software DIANA permite utilizar diversas leis constitutivas para o modelo "Total Strain Crack Model”, tanto no comportamento do material à tração quanto à compressão, sendo que algumas destas aproximações são mais refinadas e podem tornar o modelo mais robusto.

Para o comportamento no cisalhamento, o modelo pode admitir a redução do módulo de elasticidade transversal após a fissuração através da redução da rigidez transversal. Esta redução após a fissuração é opcional, podendo ser completa, constante ou variável. A redução da rigidez é realizada utilizando o coeficiente de redução de rigidez " $\beta$ " e depende, geralmente, da abertura da fissura. A influência de tal parâmetro é maior em problemas onde a ruptura do modelo ocorre por cisalhamento.

No comportamento à tração, são oferecidos sete modelos pré-definidos. As funções lineares, exponenciais e a formulação de Hordyk são baseadas na energia de fraturamento à tração do concreto (Gf). O conceito de energia de fraturamento pode ser entendido como a energia necessária para produzir um efeito irreversível de dano no material. Outro parâmetro de importância para tal modelo é o comprimento de banda da fissura, que caracteriza este efeito irreversível num dado elemento finito. Para facilitar o entendimento, a Figura 6-9 mostra graficamente estes conceitos. 


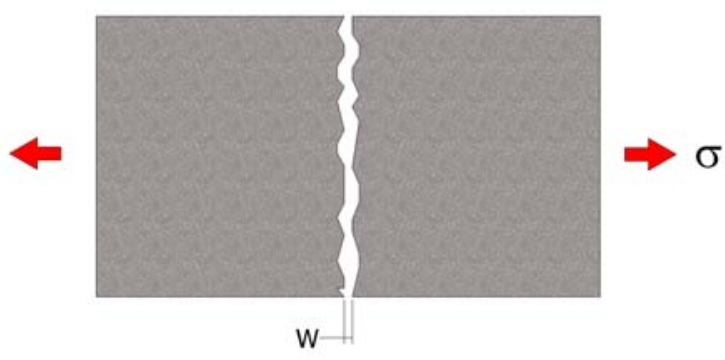

Figura 6-9 - Energia de fraturamento

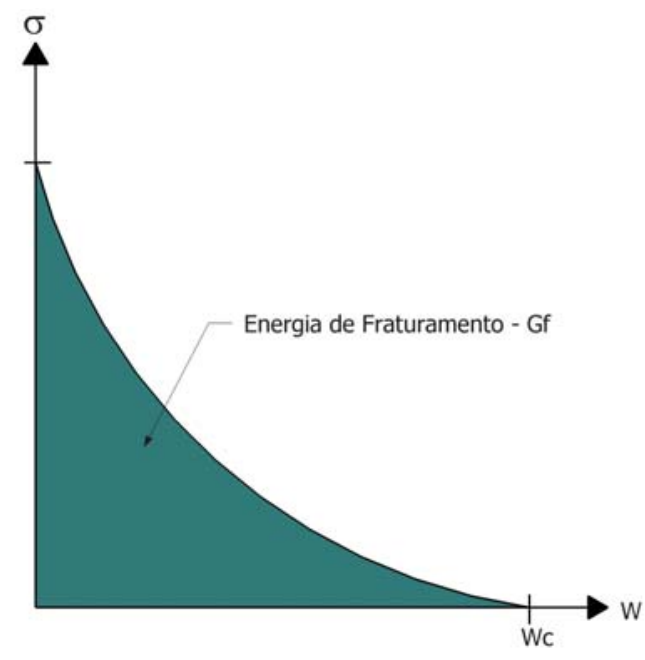

O parâmetro "h” é a largura de banda da fissura do elemento finito e é utilizado para suprir a dependência de malha do modelo. Desta forma, a caracterização do surgimento da fissura e do efeito de dano irreversível pode ser feita no determinado elemento finito. Este parâmetro pode ser fornecido pelo usuário ou calculado automaticamente utilizando o volume do elemento finito. O conjunto de Equações (6.3) mostra como o parâmetro "h” é calculado pelo software e, a Equação (6.4), como a conversão da energia de fraturamento é calculada para a fissuração do concreto.

$h=\sqrt{2 A_{e}}$ - Para elementos bidimensionais de ordem linear

$h=\sqrt{A_{e}}$ - Para elementos bidimensionais de

alta ordem

$h=\sqrt[3]{V_{e}}$ - Para elementos tridimensionais

$g_{f}=\frac{G_{f}}{h}$

$A_{e}=$ Área do elemento finito

$V_{e}=$ Volume do elemento finito

Para o comportamento à compressão, o software DIANA oferece sete modelos predefinidos, que podem ser implementados para a consideração ou não do efeito do confinamento lateral no concreto e da expansão lateral do concreto. As funções lineares e 
exponenciais são baseadas na energia de fraturamento na compressão do concreto (Gc). Da mesma forma que o parâmetro Gf, Gc caracteriza a energia necessária para o fraturamento e a ocorrência do dano irreversível na região. A Figura 6-10 exemplifica a energia de fraturamento na compressão.
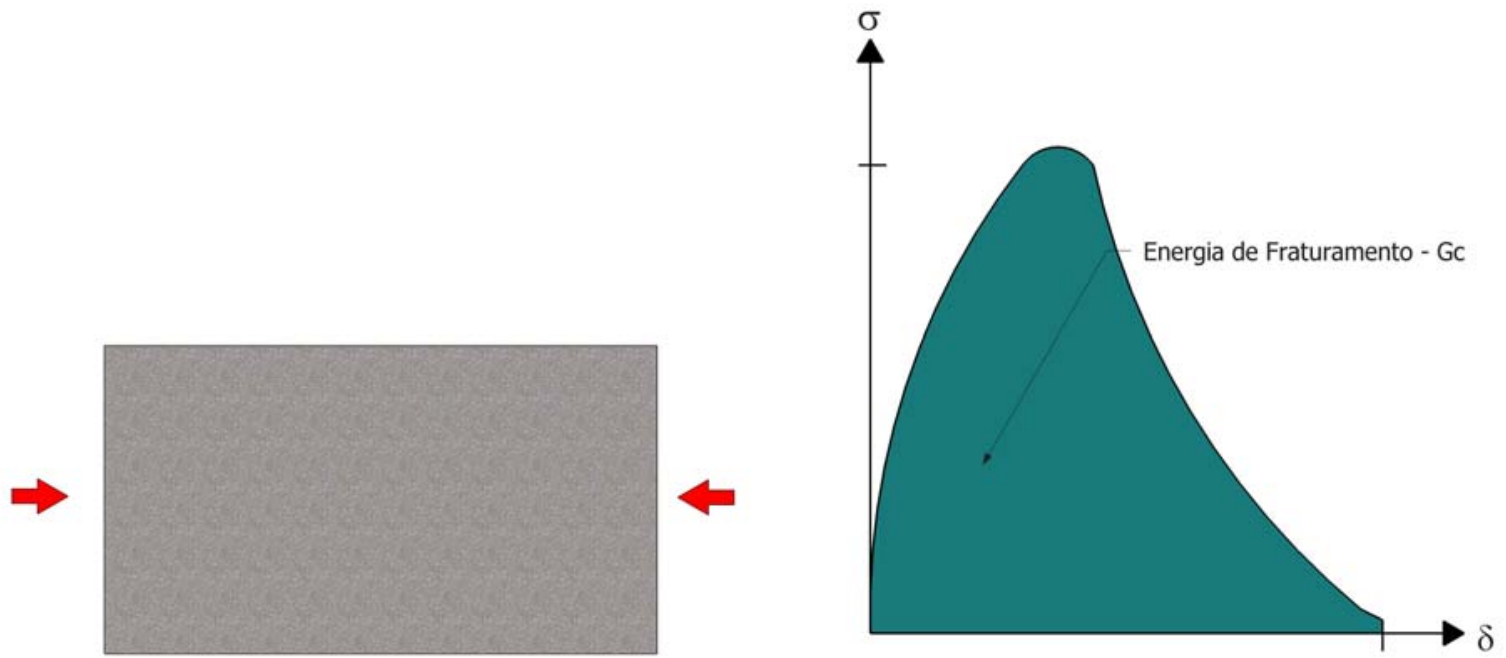

Figura 6-10 - Energia de fraturamento e comprimento de banda da fissura

Foi utilizada para o comportamento à compressão, uma função parabólica e, para o comportamento à tração, a função exponencial. Ambas as funções são caracterizadas pela energia do fraturamento (na compressão e na tração) e pela largura de banda da fissura. A Figura 6-11 mostra os modelos utilizados para simular o comportamento do concreto.

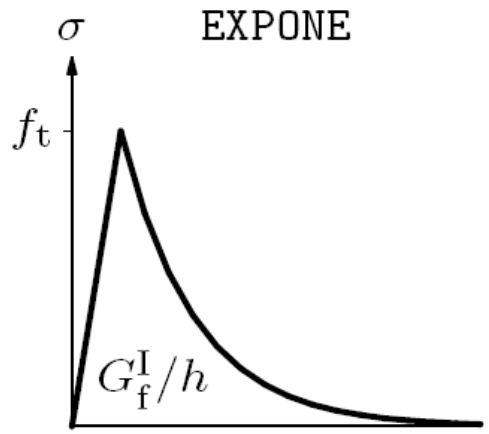

a) Função exponencial Comportamento na tração do concreto

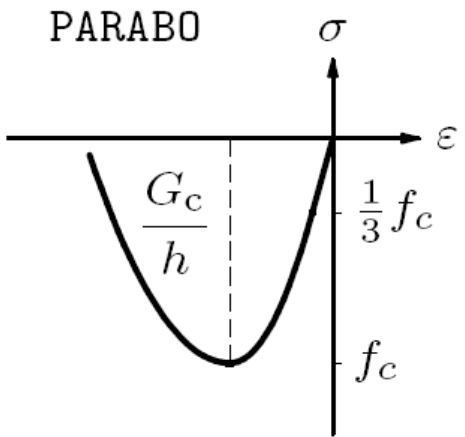

b) Função parabólica Comportamento da compressão

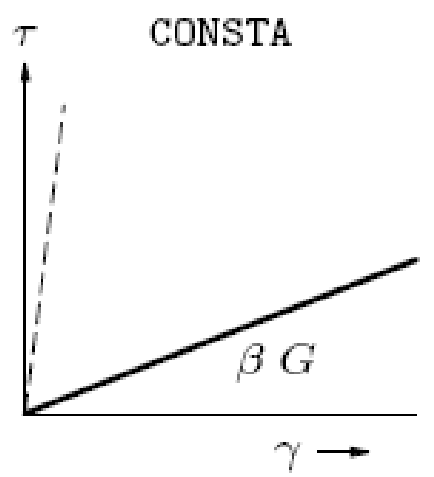

c) Função linear - redução da rigidez transversal Cisalhamento

Figura 6-11 - Comportamento do modelo constitutivos do concreto 
Na implementação do elemento de interface é necessária a introdução da rigidez linear de interface, que relaciona a tração normal e o cisalhamento na interface com o deslizamento relativo nas direções normal e tangencial. Para simular a interação entre o concreto e o aço, foi utilizada a propriedade não-linear da interface "bond-slip". O modelo não-linear de interface “bond-slip” descreve a relação entre transferência de tensões de cisalhamento na interface e o deslizamento tangencial relativo. Quando implementado o modelo não-linear “bond-slip”, a rigidez linear no cisalhamento passa a ser desconsiderada, mas a rigidez linear na direção normal à interface permanece inalterada. .

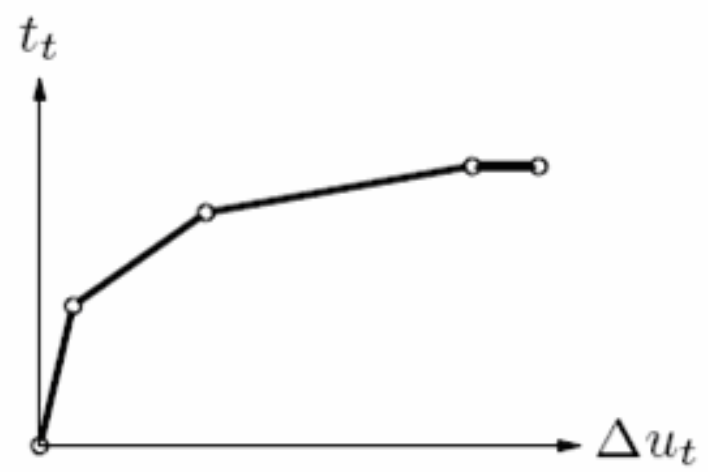

Figura 6-12 - Modelo não-linear de interface Bond-slip

Este modelo de interface é uma ferramenta importante para descrever o comportamento de interface entre armaduras e concreto, mas não se descarta a possibilidade da sua utilização em outros problemas. Deve-se atentar para o fato de que a consideração de um modelo de interface não-linear com a consideração de “Bond-slip” acaba desprezando outras variáveis importantes no comportamento da interface aço-concreto devendo, assim, ser utilizado com bastante cautela. 


\subsection{Modelo numérico final}

O modelo geométrico final se trata de um modelo tridimensional construído com elementos sólidos para o concreto e de superfície com elementos de casca para o tubo de aço e a viga metálica. São incluídos ainda elementos de armadura para simular as armaduras presentes na laje de concreto e elementos de viga para simular os parafusos.

Na modelagem foram utilizados elementos com aproximação linear na função dos deslocamentos. No decorrer do trabalho, diversos outros tipos de aproximação foram testados, desde a variação quadrática na função aproximadora dos deslocamentos, a elementos de função polinomial para os deslocamentos. O uso destes elementos finitos decorreu da intenção de utilizar elementos que fornecessem resultados adequados por um pequeno custo computacional. Para tal, foram realizadas análises com a variação dos tipos de elemento, de forma que pudessem ser testados os que pareciam mais adequados para representar o problema. A Figura 6-13 mostra os elementos utilizados para as diversas regiões do modelo de ligação.

Tabela 6-1 - Elementos finitos utilizados para as diversas regiões do modelo

\begin{tabular}{|c|c|c|c|}
\hline Região & Tipo de elemento & Graus de liberdade & $\begin{array}{c}\text { Nomenclatura } \\
\text { (DIANA) }\end{array}$ \\
\hline Núcleo de concreto & $\begin{array}{l}\text { - Sólido } \\
\text { - } 8 \text { nós } \\
\text { - Isoparamétrico } \\
\text { - Aproximação linear }\end{array}$ & $\begin{array}{l}3 \text { graus por nó - Deslocamentos } \\
\text { nas } 3 \text { direções }\end{array}$ & HX24L \\
\hline Tubo de aço & $\begin{array}{l}\text { Casca } \\
\text { - } 4 \text { nós } \\
\text { - Isoparamétrico } \\
\text { - Aproximação linear }\end{array}$ & $\begin{array}{l}5 \text { por nó - Deslocamento nas } 3 \\
\text { direções e rotação nas duas } \\
\text { direções do plano do elemento }\end{array}$ & Q20SF \\
\hline $\begin{array}{l}\text { Interface aço- } \\
\text { concreto (Pilar) }\end{array}$ & $\begin{array}{l}\text { - Interface } \\
\text { - } 8 \text { nós } \\
\text { - Isoparamétrico } \\
\text { - Aproximação linear }\end{array}$ & $\begin{array}{l}3 \text { graus por nó - Deslocamentos } \\
\text { nas } 3 \text { direções }\end{array}$ & Q24IF \\
\hline $\begin{array}{l}\text { Viga metálica - } \\
\text { Alma e Mesas }\end{array}$ & $\begin{array}{l}\text { Casca } \\
\text { - } 4 \text { nós } \\
\text { - Isoparamétrico } \\
\text { - Aproximação linear }\end{array}$ & $\begin{array}{l}5 \text { por nó - Deslocamento nas } 3 \\
\text { direções e rotação nas duas } \\
\text { direções do plano do elemento }\end{array}$ & Q20SF \\
\hline Viga metálica - & - Sólido & 3 graus por nó - Deslocamentos & HX24L \\
\hline
\end{tabular}




\begin{tabular}{|c|c|c|c|}
\hline $\begin{array}{l}\text { Chapa de } \\
\text { extremidade }\end{array}$ & $\begin{array}{l}\text { - } 8 \text { nós } \\
\text { - Isoparamétrico } \\
\text { - Aproximação linear }\end{array}$ & nas 3 direções & \\
\hline Parafusos & $\begin{array}{l}\text { - Viga } \\
\text { - } 2 \text { nós } \\
\text { - Aproximação Linear }\end{array}$ & & \\
\hline $\begin{array}{l}\text { Interação Laje - } \\
\text { Viga metálica }\end{array}$ & $\begin{array}{l}\text { - Interface } \\
\text { - } 8 \text { nós } \\
\text { - Isoparamétrico } \\
\text { - Aproximação linear }\end{array}$ & $\begin{array}{l}3 \text { graus por nó - Deslocamentos } \\
\text { nas } 3 \text { direções }\end{array}$ & Q24IF \\
\hline Laje de concreto & $\begin{array}{l}\text { - Sólido } \\
\text { - } 8 \text { nós } \\
\text { - Isoparamétrico } \\
\text { - Aproximação linear }\end{array}$ & $\begin{array}{l}3 \text { graus por nó - Deslocamentos } \\
\text { nas } 3 \text { direções }\end{array}$ & HX24L \\
\hline
\end{tabular}
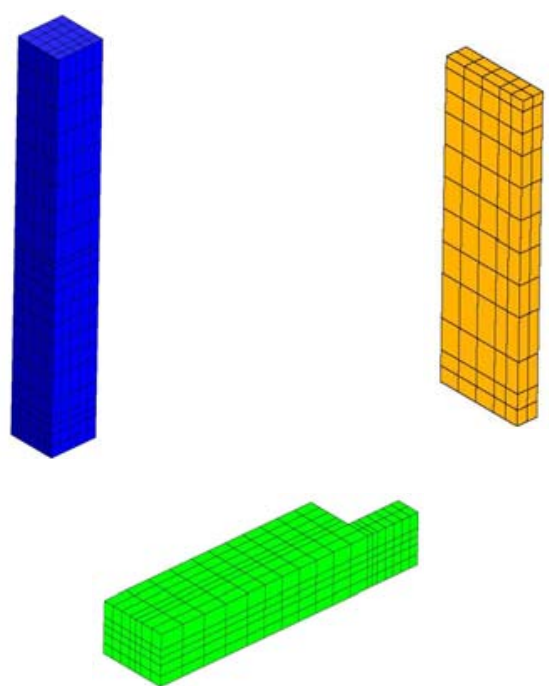

a) Elementos sólidos - HX24L - Laje de concreto, núcleo de concreto, chapa de extremidade
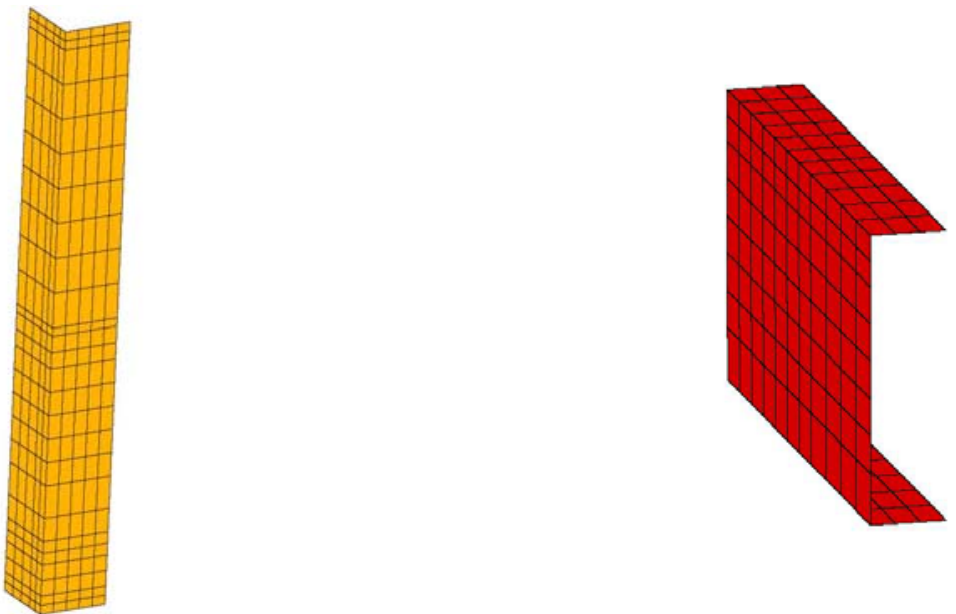

c) Elemento de casca - Q20SF - Tubo metálico do pilar e viga metálica da ligação

Figura 6-13 - Detalhes dos elementos utilizados para cada material 
As variáveis necessárias para alimentar o modelo numérico de cada material foram obtidas, na sua grande maioria, nos ensaios experimentais de caracterização dos materiais. Algumas das variáveis foram calibradas de acordo com os resultados obtidos ou com formulações da literatura. A Tabela 6-2 reúne as variáveis e os valores numéricos utilizados para os modelos constitutivos.

Tabela 6-2 - Modelos constitutivos da simulação numérica

\begin{tabular}{cc}
\hline & Concreto \\
Comportamento na compressão & Parabólico \\
\hline Resistência a compressão & $50 \mathrm{MPa}$ \\
\hline Gc & $5 \mathrm{Nmm} / \mathrm{mm}^{2}$ \\
\hline Comportamento na Tração & Exponencial \\
\hline Resistência a tração & $3,2 \mathrm{MPa}$ \\
\hline Gf & $0,01 \mathrm{Nmm} / \mathrm{mm}^{2}$ \\
Retenção ao cisalhamento & Linear \\
\hline$\beta$ & Aço \\
\hline Plastificação & Elasto-plastico perfeito - Von Misses \\
\hline Tensão de escoamento & $350 \mathrm{MPa}$ \\
\hline Plastificação & Armadura \\
\hline Tensão de escoamento & Elasto-plastico perfeito - Von Misses \\
\hline
\end{tabular}

Para relacionar a transferência de tensões entre o aço e o concreto foi utilizado um modelo de comportamento do tipo "bond-slip", que foi calibrado com os resultados experimentais de SILVA (2006) e verificado a partir das análises iniciais citadas anteriormente. A Figura 6-14 mostra a curva bond-slip adotada.

No modelo experimental foi considerada a interação total entre a viga metálica e a laje de concreto. Embora esta hipótese seja válida, a rigidez inicial dos conectores de cisalhamento soldados à viga de aço permite que ocorra inicialmente um deslizamento relativo entre a viga e laje, até que estes conectores sejam mobilizados e a interação entre os dois materiais se desenvolva e seja total. 


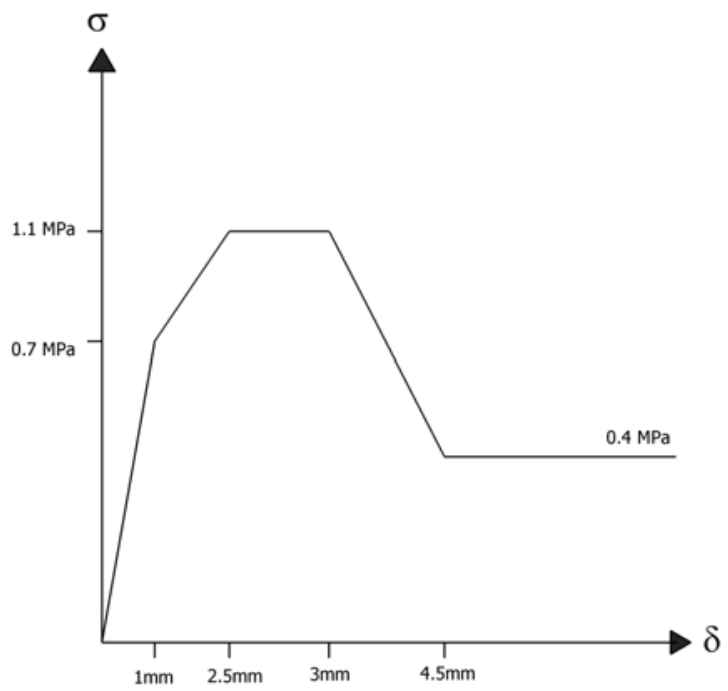

Figura 6-14 - Modelo "Bond-slip” utilizado na análise numérica

Nos primeiros modelos analisados foi percebido que o uso da interação total entre a laje e a viga tornava o modelo numérico muito rígido. Desta forma, foi permitido um deslizamento mínimo inicial a fim de representar melhor a interação entre a laje de concreto e a viga de aço. Este deslizamento foi implementado utilizando elementos de interface na região.

Da mesma forma que no modelo experimental, a introdução das forças externas ocorreu via núcleo de concreto do pilar misto. Por problemas de convergência, no entanto, o procedimento foi o inverso, inserindo as vinculações na seção de concreto e aplicando o carregamento na laje de concreto.

A carga foi aplicada no modelo numérico por meio de deslocamento imposto, já que este procedimento fornece processamentos mais estáveis e evita problemas de convergência, de acordo com o "solver” utilizado.

Conforme comentado anteriormente, foi utilizado plano de simetria no modelo numérico. Para introduzir a simetria são inseridas condições de contorno nos planos simétricos. Para a simetria no eixo X são vinculados os graus de liberdade de deslocamento no eixo $\mathrm{X}$ e rotação nos eixos $\mathrm{Y}$ e Z. Procedimento similar foi adotado para o eixo $\mathrm{Y}$, 
restringindo o deslocamento no eixo Y e a rotação nos eixos X e Z. A Figura 6-15 mostra a aplicação das cargas externas, condições de contorno e planos de simetria adotados no modelo numérico.

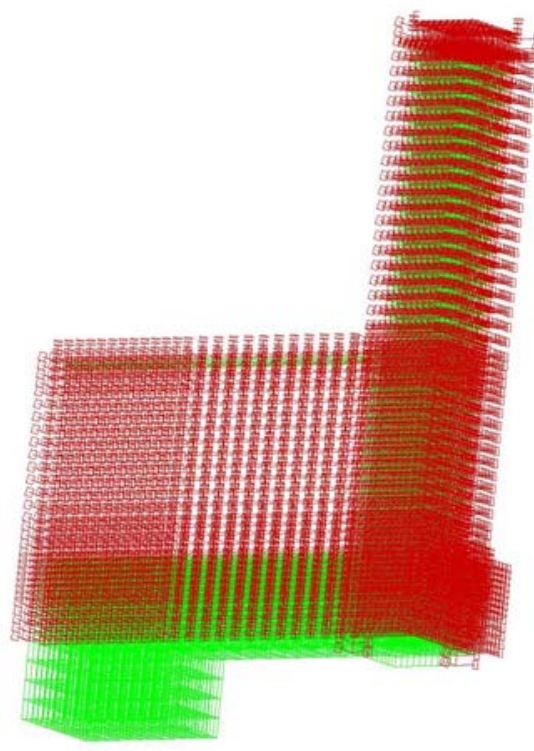

a) Condições de contorno para plano de simetria

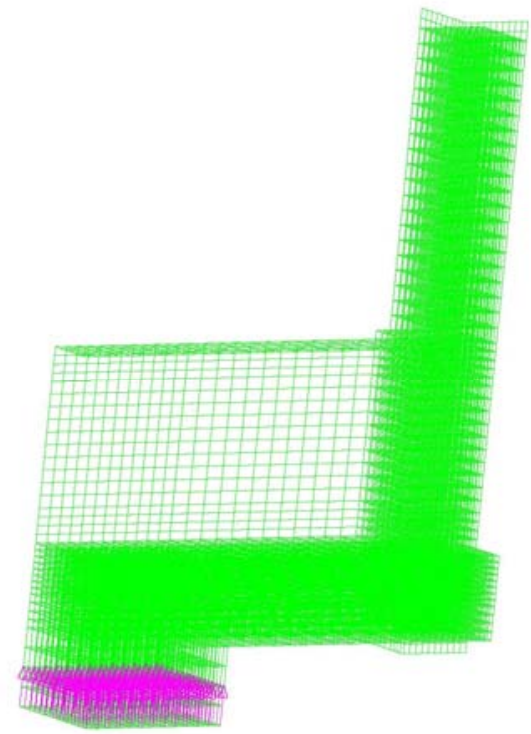

b) Carregamento aplicado

Figura 6-15 - Condições de contorno, ações externas e planos de simetria do modelo numérico.

O “solver" utilizado foi baseado no método de Newton-Rapson. A aplicação do deslocamento foi realizada por meio de passos de carga específicos de 0,0075 mm, e a tolerância da norma de convergência foi de 0,01, tanto para a força como para o deslocamento. Em alguns pontos de perda de convergência do modelo foi necessário reduzir o passo de carga ou aumentar a tolerância de 0,01 para 0,015 ou 0,02 para que o processamento pudesse continuar. A não-linearidade geométrica foi habilitada no processamento, apesar de seu uso aumentar substancialmente o custo computacional.

No total o modelo possui de 16216 a 20000 nós e de 14968 a 18000 elementos, variando de acordo com o refinamento necessário. Para verificar a adequação do refinamento da malha de elementos finitos, foram processados alguns modelos com diferentes graus de refinamento para assim obter aquele que fornecesse resultados adequados (quando comparado 
ao modelo menos refinado) e com baixo custo computacional. A Figura 6-16 mostra o modelo numérico final.

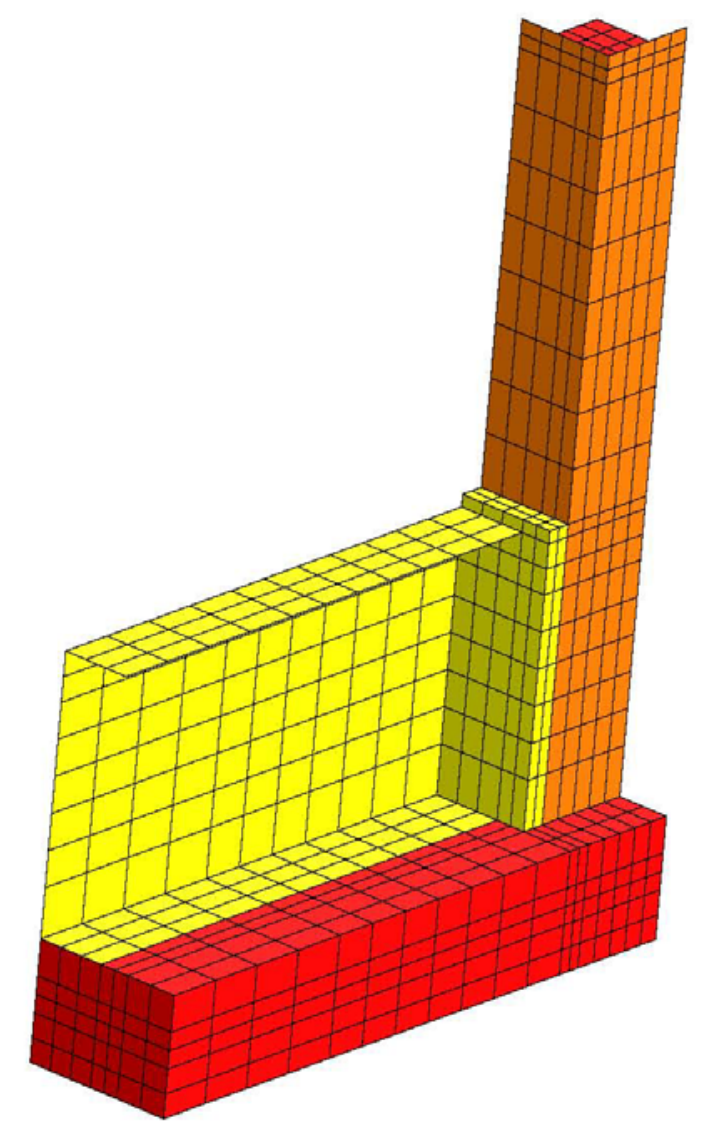

Figura 6-16 - Modelo final de elementos finitos.

\subsection{Resultados do modelo numérico}

O modelo numérico final foi avaliado e calibrado a partir dos resultados obtidos experimentalmente para o modelo CC_W. A partir desses resultados foi possível melhorar a representatividade do modelo numérico para que o seu comportamento, quando confrontado com os resultados obtidos experimentais, fosse o melhor possível.

Diversas limitações acabaram prejudicando estes resultados, tais como o tempo de processamento, que não permitiu a realização de um número maior de análises. 
O modelo numérico apresentou comportamento mais rígido que o modelo experimental, para todos os componentes da ligação. Os resultados de deslizamento relativo do concreto foram bastante satisfatórios, pois apresentaram coerência e se aproximaram bastante dos valores do modelo experimental. Quanto à carga de ruptura, o valor obtido numericamente, apesar de menor que o experimental, foi bastante próximo deste. A carga máxima atingida no modelo numérico foi de $810 \mathrm{kN}$, enquanto a carga do modelo experimental foi cerca de $870 \mathrm{kN}$. O modelo numérico não atingiu nenhum modo de falha específico mas, neste patamar de carga, não se conseguiu atender aos critérios de convergência. Acredita-se que, neste instante, a fissuração intensa da laje de concreto e a plastificação das armaduras contribuíram para a não convergência do modelo numérico. A Figura 6-17 mostra a comparação entre resultados numéricos e experimentais de deslizamento relativo do concreto.

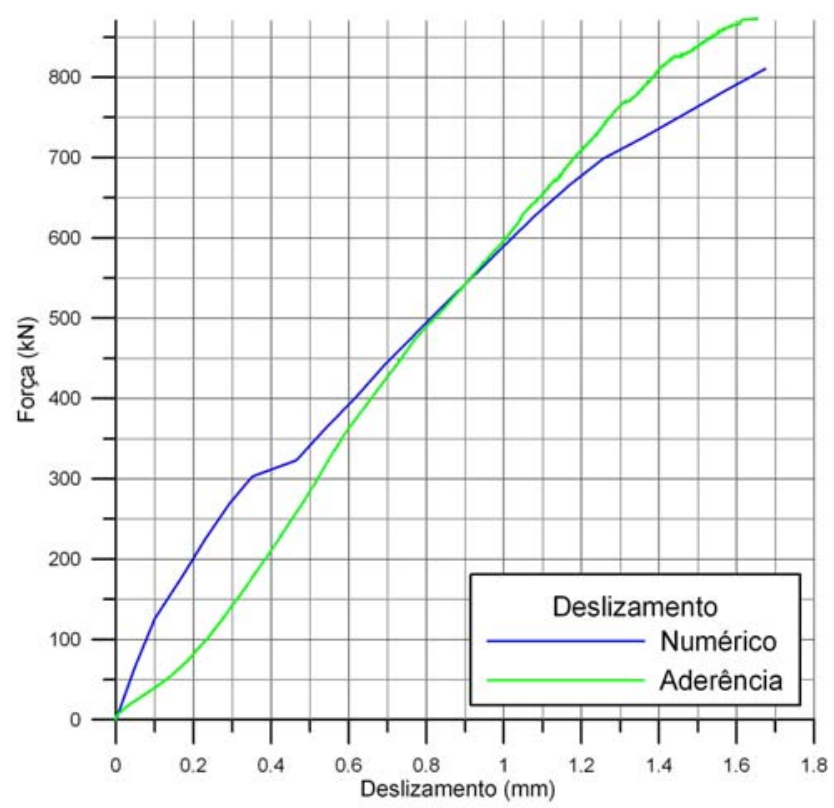

Figura 6-17 - Deslizamento relativo do núcleo de concreto

A transferência de tensões entre os dois materiais também pôde ser observada pelas medições realizadas experimentalmente no núcleo de concreto do pilar. Quanto à transferência de tensões, o modelo numérico apresentou resultados mais coerentes, já que na 
análise experimental a medição dos extensômetros não forneceu resultados satisfatórios, concluindo-se que os efeitos concentrados no tubo metálico prejudicaram a análise. Para o modelo numérico, a presença da ligação e dos parafusos também prejudicou a análise da transferência de tensões, pois a concentração de esforços provenientes dos parafusos e da rotação da viga metálica perturbou os resultados de tensão axial no perfil tubular. A Figura 6-18 evidencia o ocorrido destacando a concentração destes esforços.
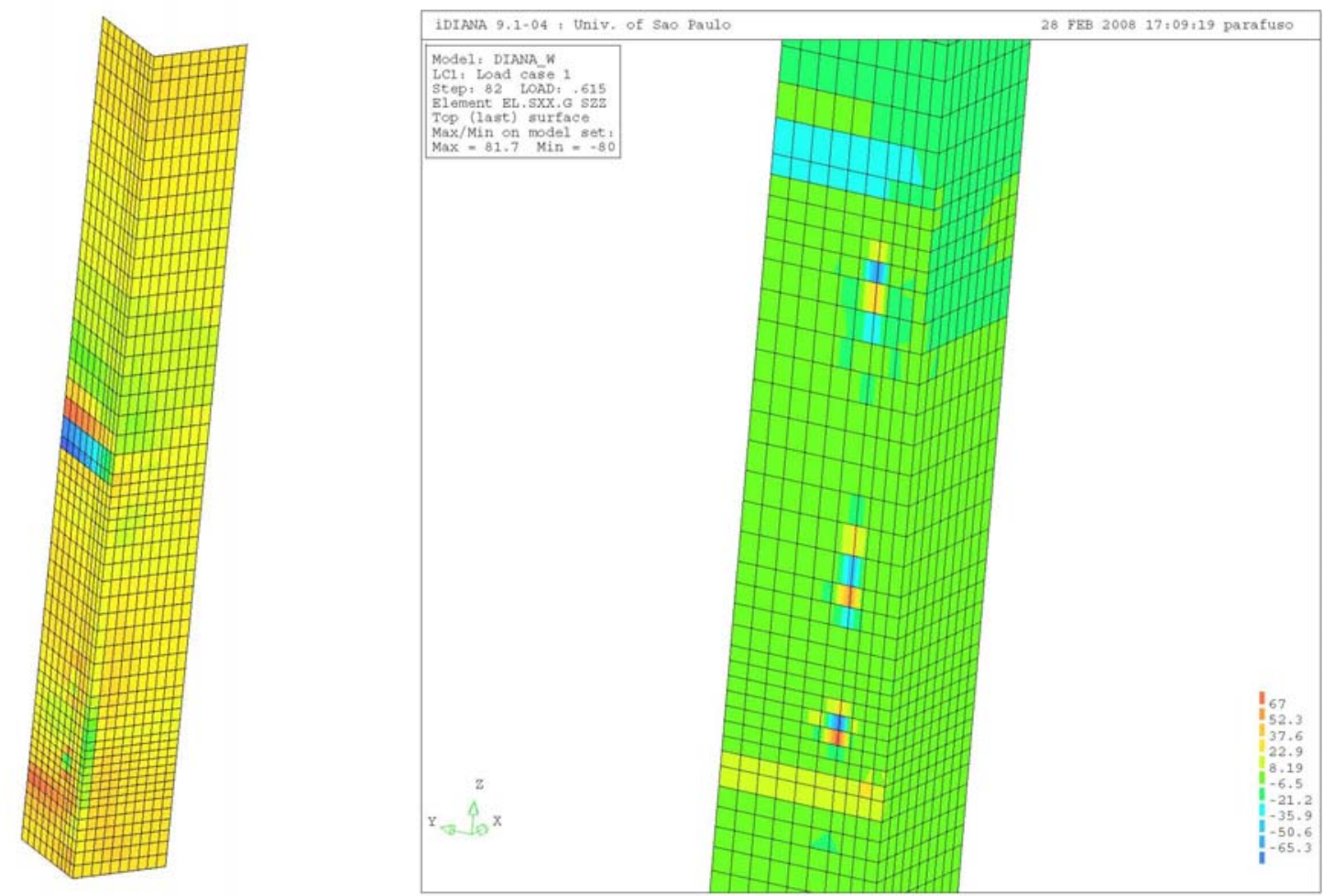

Figura 6-18 - Tensão cisalhante no tubo metálico e concentração de tensões dos parafusos e da ligação.

Entretanto, a transferência de forças pode ser observada acompanhando a evolução do deslizamento relativo na interface e de suas reações. As deformações no núcleo de concreto do modelo numérico também possibilitaram analisar a transferência de forças entre os dois materiais. A forma de implementar a transferência de forças usando elementos de interface pareceu bastante adequada pois, mesmo sendo mais simples que as demais alternativas analisadas, forneceu resultados bastante satisfatórios e coerentes. A Figura 6-19 mostra o deslizamento relativo do núcleo de concreto em relação ao perfil de aço. 


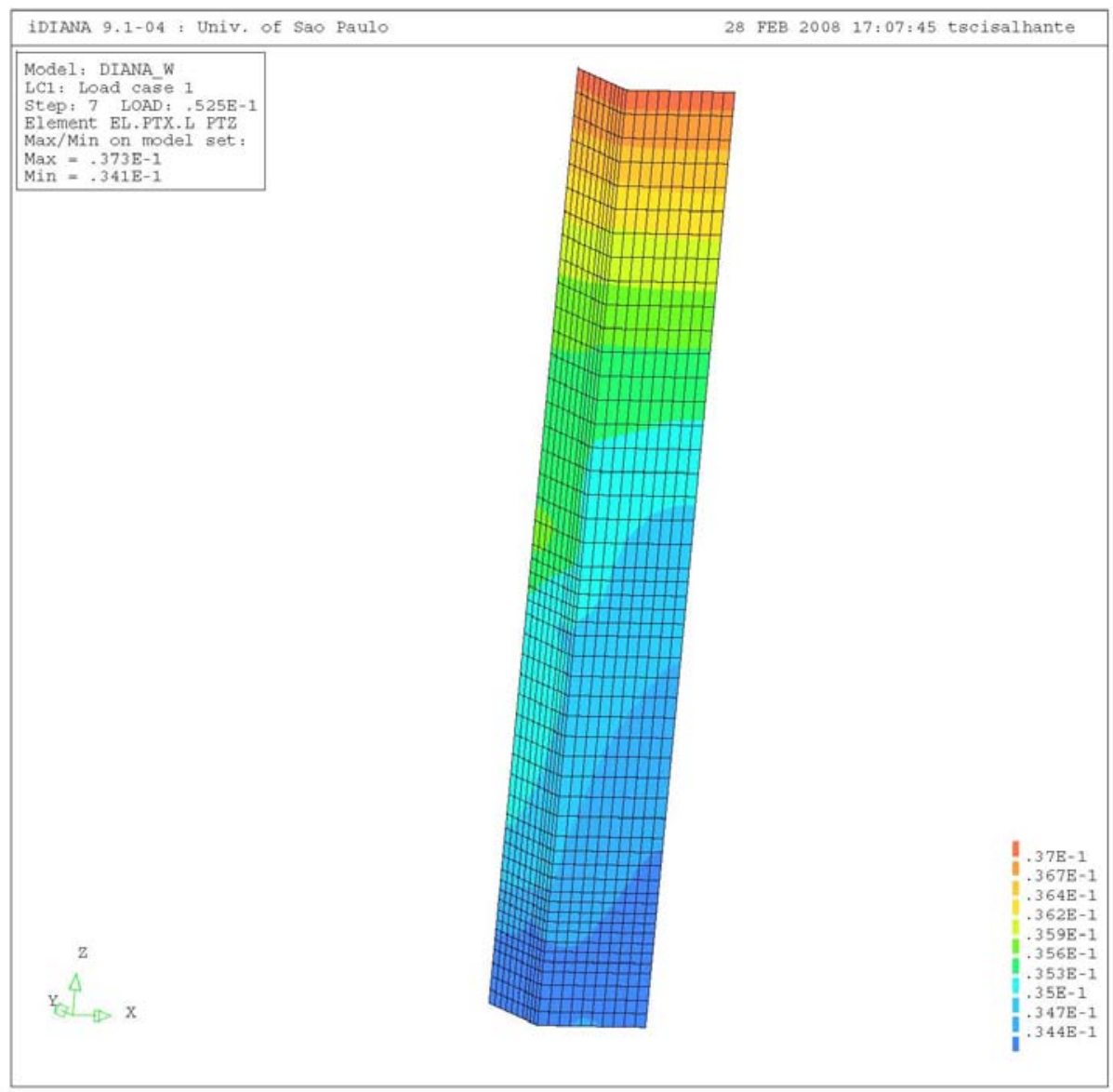

Figura 6-19 - Deslizamento relativo do perfil de aço em relação ao núcleo de concreto.

Um dos principais problemas do modelo numérico foi a representação da interação da laje de concreto com a viga metálica, pois os parâmetros de interface nesta região causavam grande influência na distribuição de esforços na laje. Para a resolução deste problema, foi permitido um deslizamento inicial entre os dois componentes para que, posteriormente, se desenvolvesse a sua interação total.

Apesar deste problema, o comportamento da laje de concreto e os resultados obtidos para as armaduras foram bastante satisfatórios, principalmente quanto à localização inicial da fissuração. Como no modelo experimental, as armaduras localizadas nas extremidades da laje foram as mais solicitadas, chegando a entrar no trecho plástico. A Figura 6-20 mostra o comportamento das armaduras da laje de concreto no final do carregamento onde, a armadura principal, localizada na extremidade da laje, encontra-se na fase plástica. 


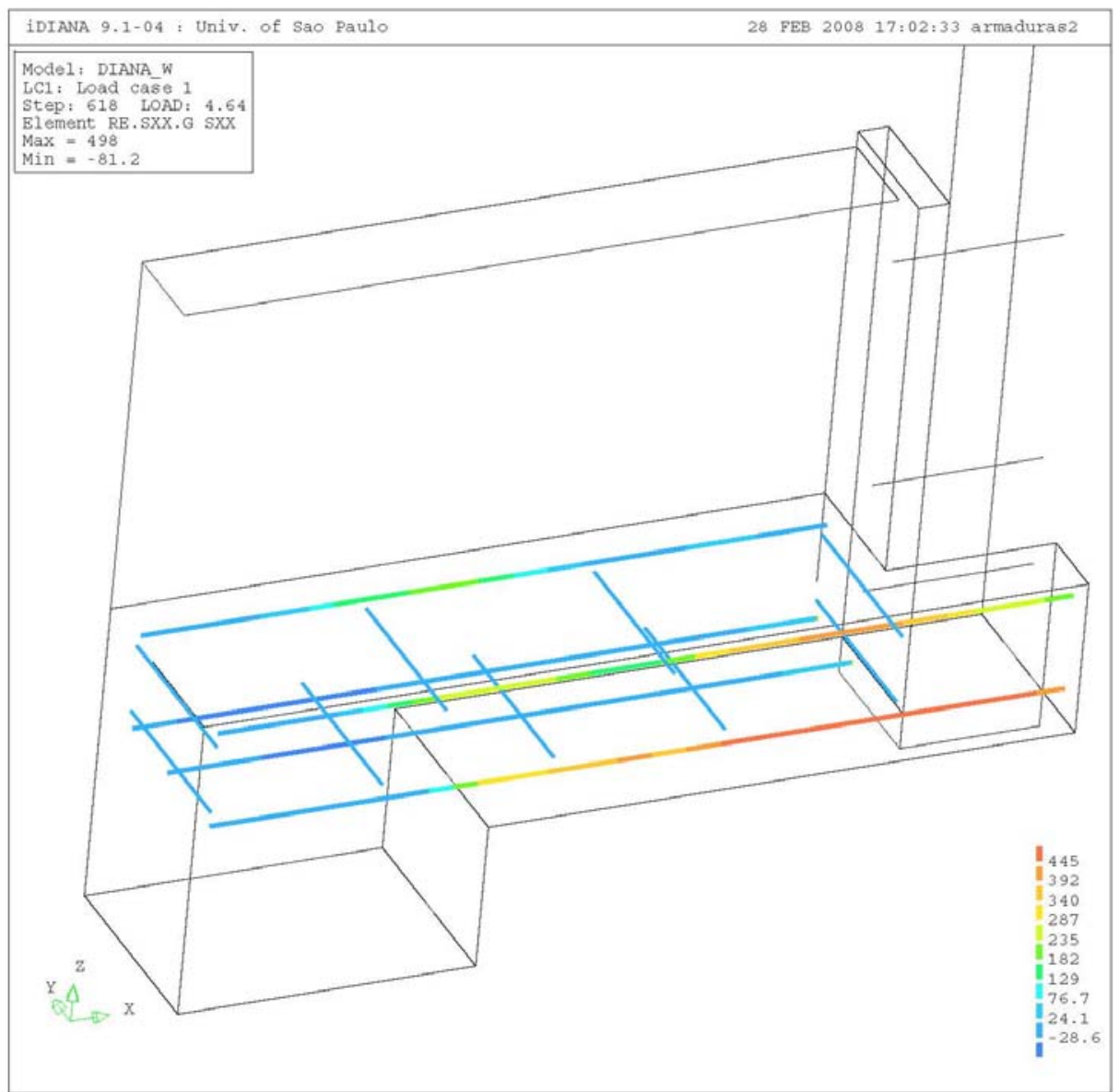

Figura 6-20 - Armaduras da laje de concreto no modelo numérico

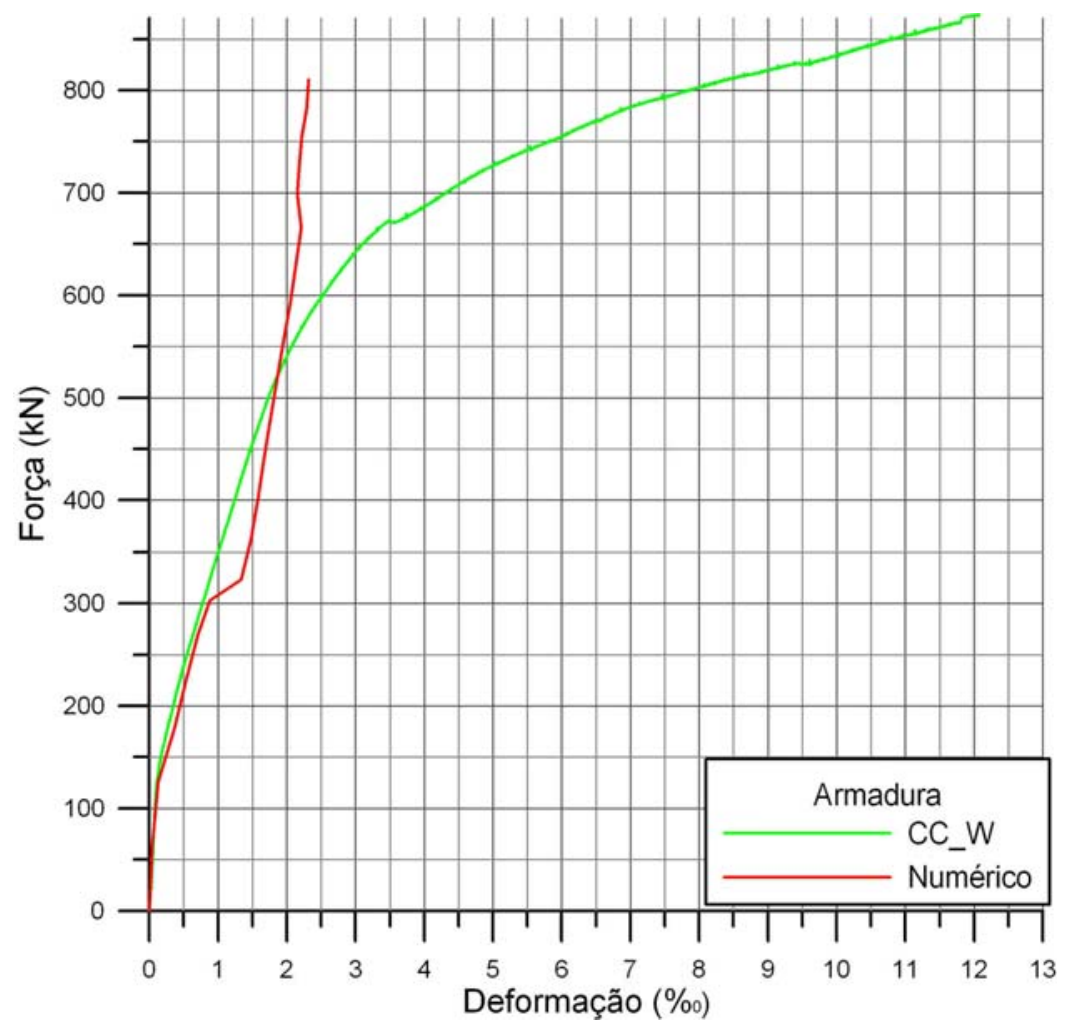

Figura 6-21 - Deformações das armaduras. Numérico e experimental 
No modelo numérico, inicialmente a região da laje não se encontra totalmente tracionada, com o posicionamento da linha neutra em dois pontos da seção mista, um na laje e outro na viga metálica, indicando interação parcial aço-concreto. O comportamento se assemelha a um modelo de bielas e tirantes, e acredita-se que isto se deve isto ao tamanho reduzido do vão. Entretanto, isto ocorre apenas no trecho inicial do carregamento, quando a interação da laje de concreto com a viga metálica ainda é parcial. Para cargas superiores, a seção mista assume apenas uma linha neutra. Com a fissuração da laje de concreto ocorre um prejuízo na visualização de resultados das tensões no concreto da laje propriamente dita, e a análise dos resultados passa a ser realizada com a verificação do comportamento das armaduras. A Figura 6-22 mostra a região tracionada e comprimida da laje de concreto nas etapas iniciais do carregamento, sendo que a região em vermelho indica tração na laje. Notase, pela distribuição de tensões, que a linha neutra corta a laje de concreto.

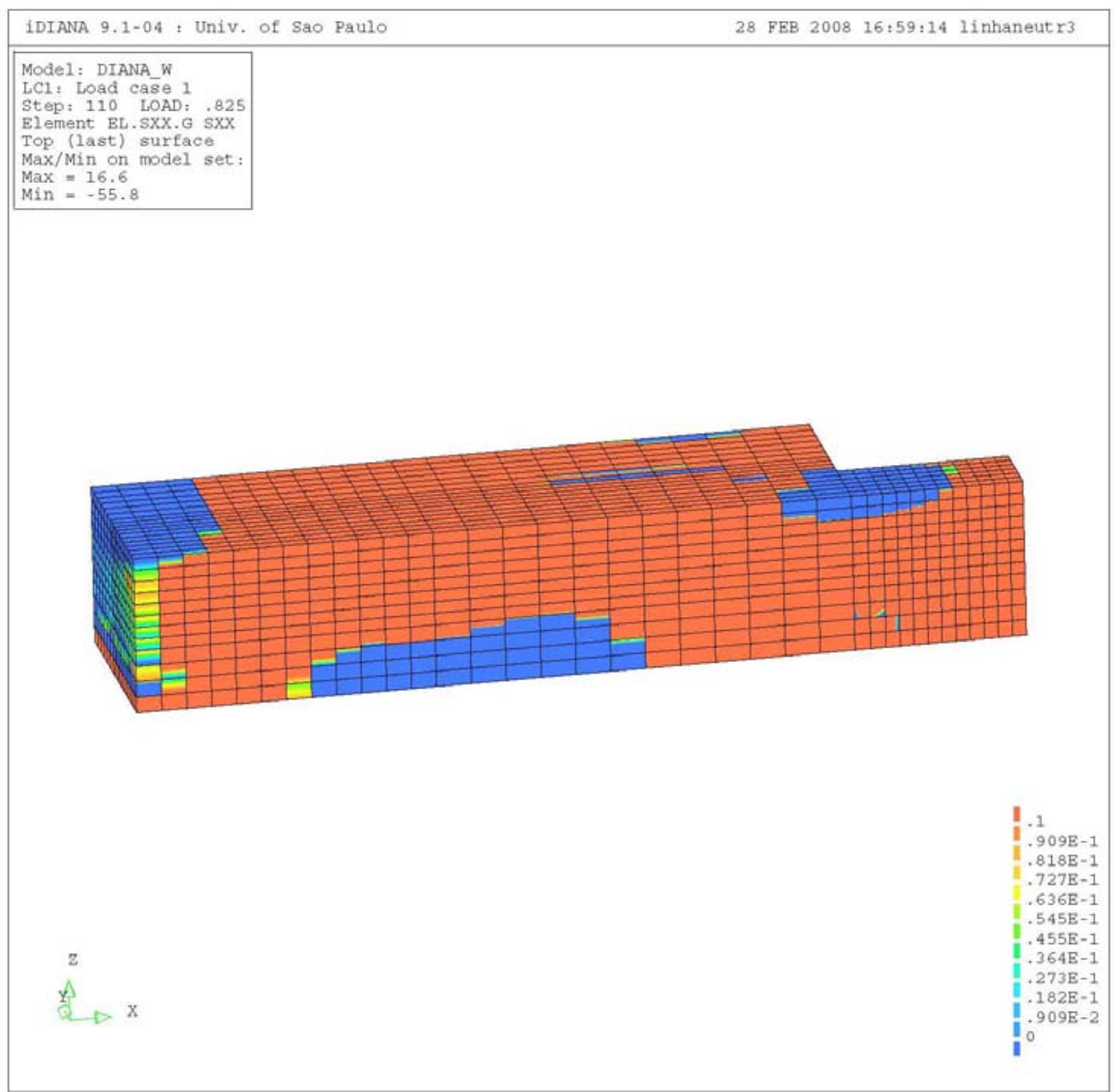

Figura 6-22 - Comportamento da laje de concreto. 
Apesar de o modelo numérico apresentar maior rigidez em todos os seus componentes quando comparado com o modelo experimental, a fissuração da laje de concreto foi mais acentuada na simulação numérica. No modelo experimental, os primeiros sinais de fissuras começaram a aparecer quando a carga aplicada atingia por volta de $300 \mathrm{kN}$. Para o modelo numérico, a fissuração da laje começou a ocorrer de forma mais acentuada um pouco depois de atingidos $210 \mathrm{kN}$. Para uma carga de $100 \mathrm{kN}$, apareceram as primeiras fissuras no modelo numérico, mas de valores não significativos. A Figura 6-23 mostra a evolução da fissuração no modelo numérico com as respectivas cargas.

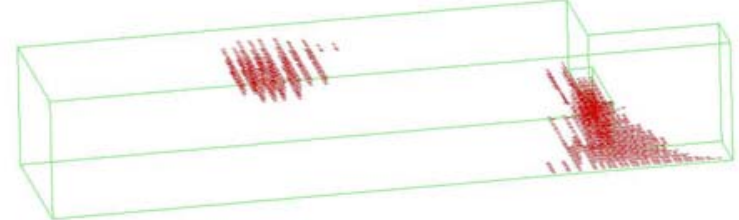

a) $106 \mathrm{kN}$

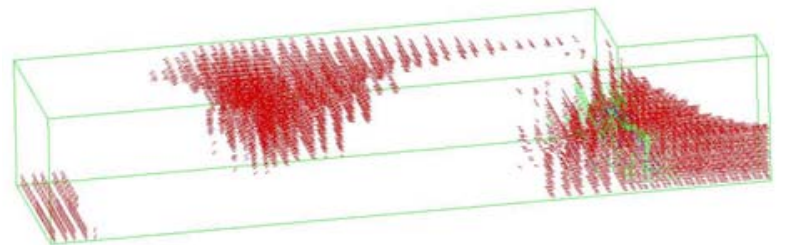

c) $200 \mathrm{kN}$

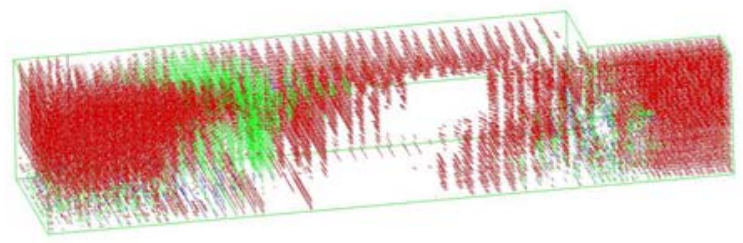

e) $320 \mathrm{kN}$

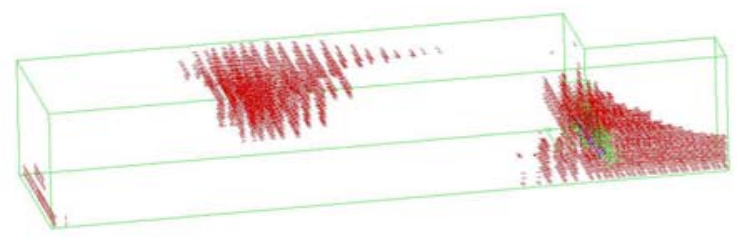

b) $154 \mathrm{kN}$

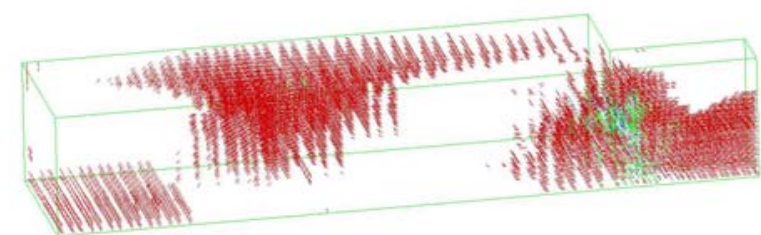

d) $270 \mathrm{kN}$

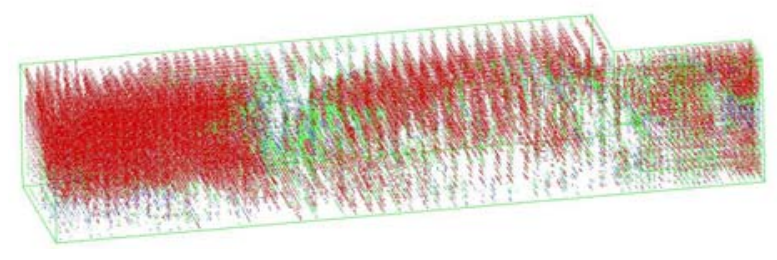

f) $820 \mathrm{kN}$

Figura 6-23 - Fissuração da laje de concreto no modelo numérico.

O panorama de comportamento da fissuração da laje no modelo numérico se assemelha, em muito, ao modelo experimental, sobretudo na localização das fissuras iniciais. Nos dois casos, as fissuras se concentraram nas proximidades do pilar, do apoio e na parte superior da laje no meio do vão. 

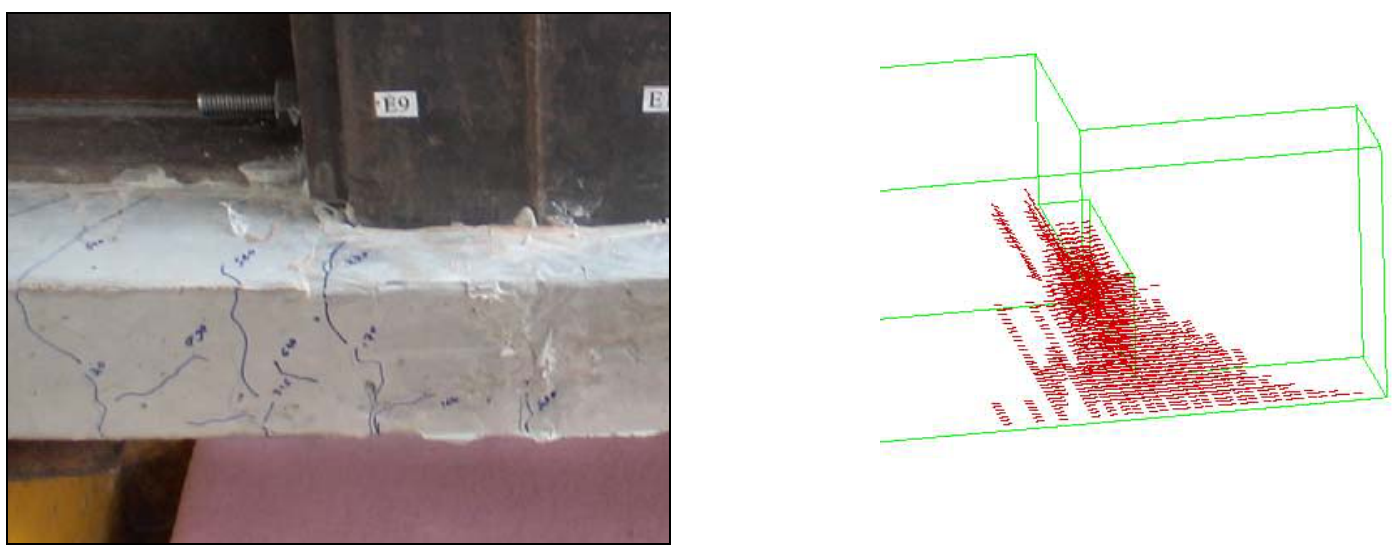

a) Fissuras nas proximidades do pilar
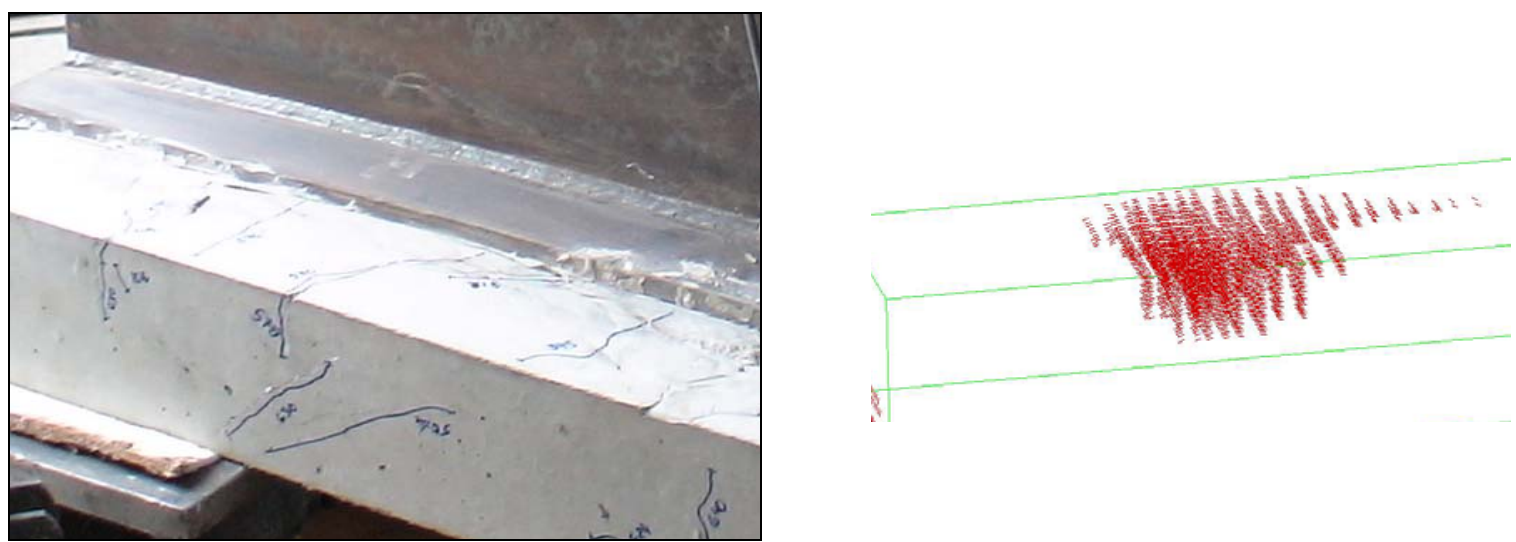

b) Fissuras na parte superior da laje (proximidade com a viga de aço)

Figura 6-24 - Comparação de fissuração do modelo numérico com experimental.

A variação da linha neutra ao longo do deslocamento aplicado no modelo numérico atravessou a viga metálica. O comportamento da viga metálica em função do carregamento foi sempre elástico sem atingir, em nenhum momento, o limite elástico. Desta forma, nas etapas iniciais de carregamento, os valores de deformação na viga metálica foram muito similares aos valores registrados experimentalmente. Nas etapas finais de carregamento, o comportamento experimental se diferenciou do numérico, enquanto que o numérico apresentou-se linear. No estudo experimental foi observada uma deformação localizada na viga de aço e estes efeitos localizados podem ter perturbado as deformações obtidas pelo extensômetros. A Figura 6-25 mostra as deformações em dois trechos da alma da viga metálica, nos pontos A1 e A4 e a comparação com os resultados numéricos, enquanto a 
Figura 6-26 mostra a configuração deformada da viga (juntamente com as tensões normais na seção da viga metálica) e os resultados de deformações numéricas da mesa da viga metálica.
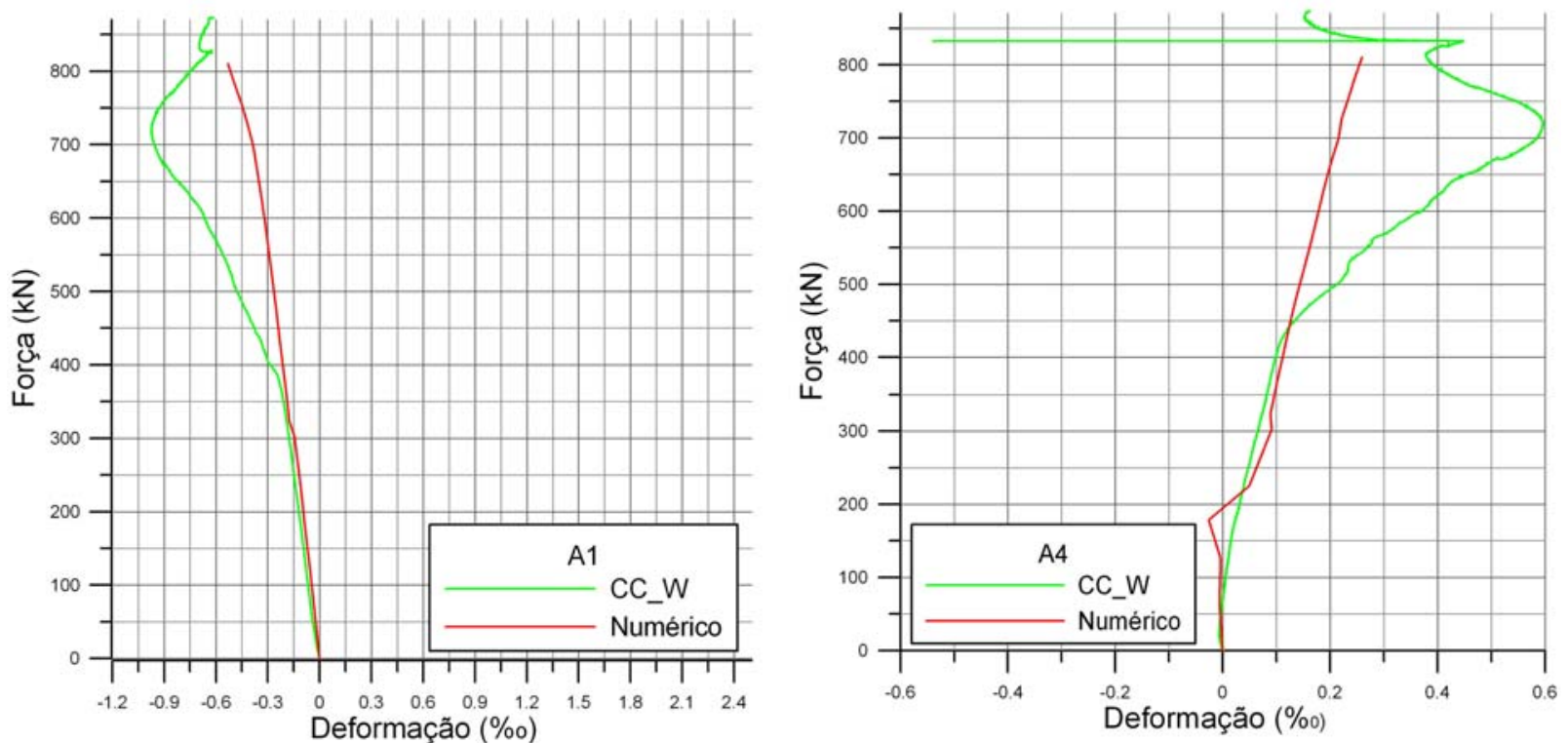

Figura 6-25 - Deformação na alma da viga metálica.
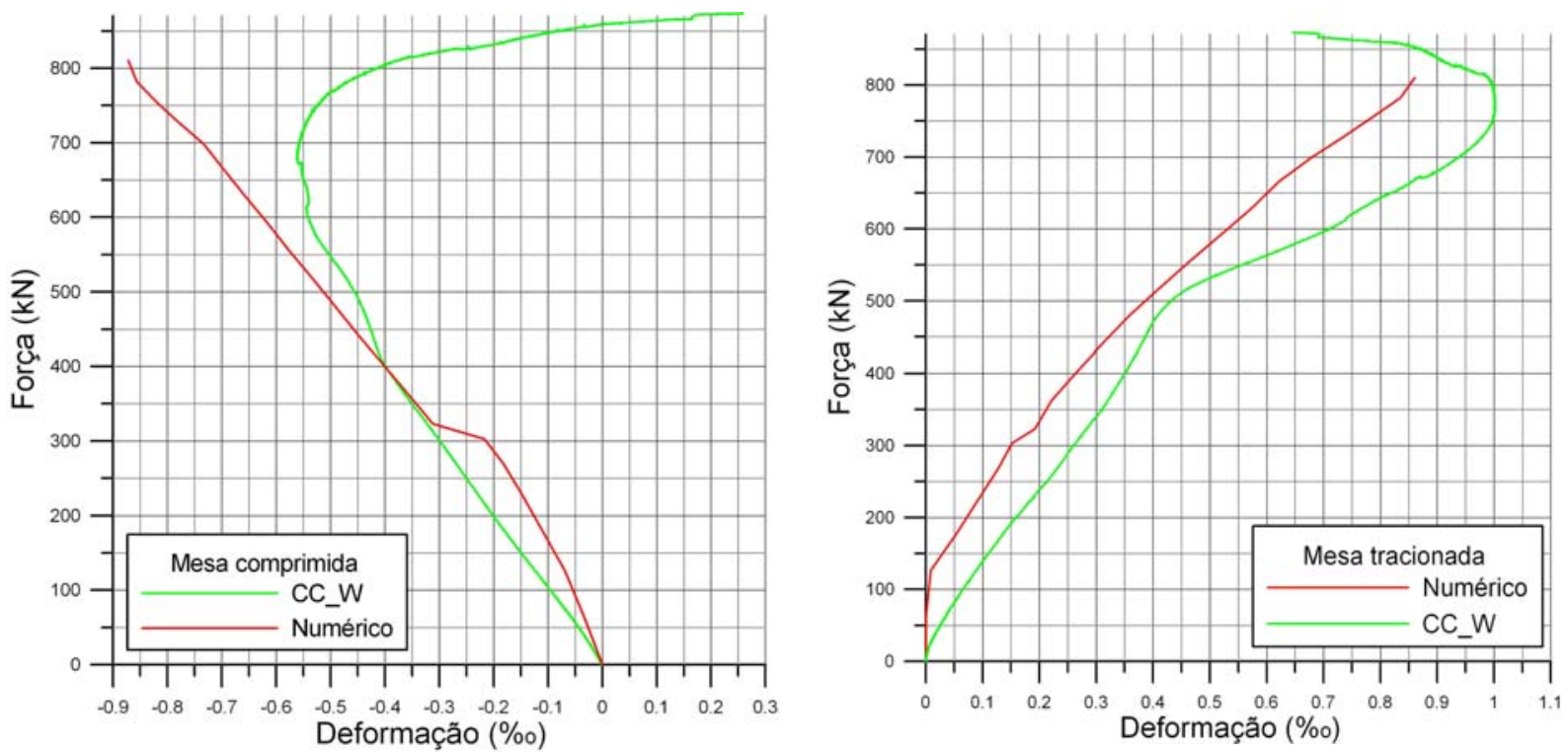

Figura 6-26 - Deformação da viga metálica

Os resultados fornecidos pela análise numérica foram bastante satisfatórios, já que, para os principais pontos analisados, o modelo numérico se assemelhou muito ao modelo experimental. A carga atingida pelo modelo numérico se aproximou da carga de ruptura do modelo experimental. 
A partir dos resultados obtidos no do modelo numérico pôde-se concluir que as armaduras constituem o componente determinante no comportamento da ligação, já que os demais componentes, tais como o perfil tubular e a viga metálica, foram pouco solicitados e não ultrapassaram o limite elástico.

\subsection{Análise paramétrica}

A partir dos resultados satisfatórios e da representatividade do modelo numérico em relação ao experimental, foi possível extrapolar a análise numérica, variando alguns parâmetros e, desta forma, ampliando as conclusões e permitindo o entendimento mais completo do modelo estudado.

Procurou-se não estender muito o número de modelos analisados, devido ao alto custo computacional exigido e à perda de objetividade da análise. Como as armaduras da laje foram o principal componente no comportamento da ligação e fator determinante para a sua ruína, este foi o principal parâmetro considerado. Desta forma, foram realizadas apenas três variações: variação na taxa de armadura da laje de concreto, variação da disposição das armaduras (ancoragem) e verificação da influência da resistência do concreto no comportamento global do modelo.

Os demais parâmetros, como os modelos constitutivos, tipos de elementos, métodos de resolução, geometria, condições de contorno e outros, foram mantidos idênticos ao modelo proposto. Os resultados obtidos na análise paramétrica serão analisados via deformação nas armaduras principais dos modelos e considerando a curva Reação vs. Deslocamento aplicado. 


\subsubsection{Análise da influência da taxa de armadura}

A armadura da laje foi o componente determinante para a ruptura do modelo de ligação estudado. A fim de avaliar a influência deste parâmetro, foram analisados mais três modelos com taxas de armadura distintas do modelo inicial avaliado experimentalmente, sendo dois deles com taxa de armadura superior e um terceiro com taxa de armadura inferior. Com a variação de tal parâmetro, foi possível verificar se a inclusão ou retirada de área de armadura pode influir no comportamento do modelo quanto à sua resistência e rigidez. O modelo original possui uma taxa de armadura de 0,85\%. A Tabela 6-3 mostra a taxa de armadura dos modelos considerados na análise paramétrica.

Tabela 6-3 - Modelos numéricos - Variação de taxa de armadura

\begin{tabular}{cc}
\hline Modelo (nomenclatura) & Taxa de armadura (\%) \\
\hline CC_W_num & $0,85 \%$ \\
\hline CC_W_tax075 & $0,75 \%$ \\
\hline CC_W_tax105 & $1,05 \%$ \\
\hline CC_W_tax160 & $1,6 \%$ \\
\hline
\end{tabular}

O aumento da taxa de armadura promoveu apenas um pequeno aumento da resistência do modelo. Apesar das armaduras serem o componente preponderante para o comportamento da ligação, a inclusão das armaduras não resultou em vantagens significativas, apenas em um aumento discreto de resistência. A Figura 6-27 mostra o comportamento do modelo perante o deslocamento aplicado, para as várias taxas de armadura consideradas. 


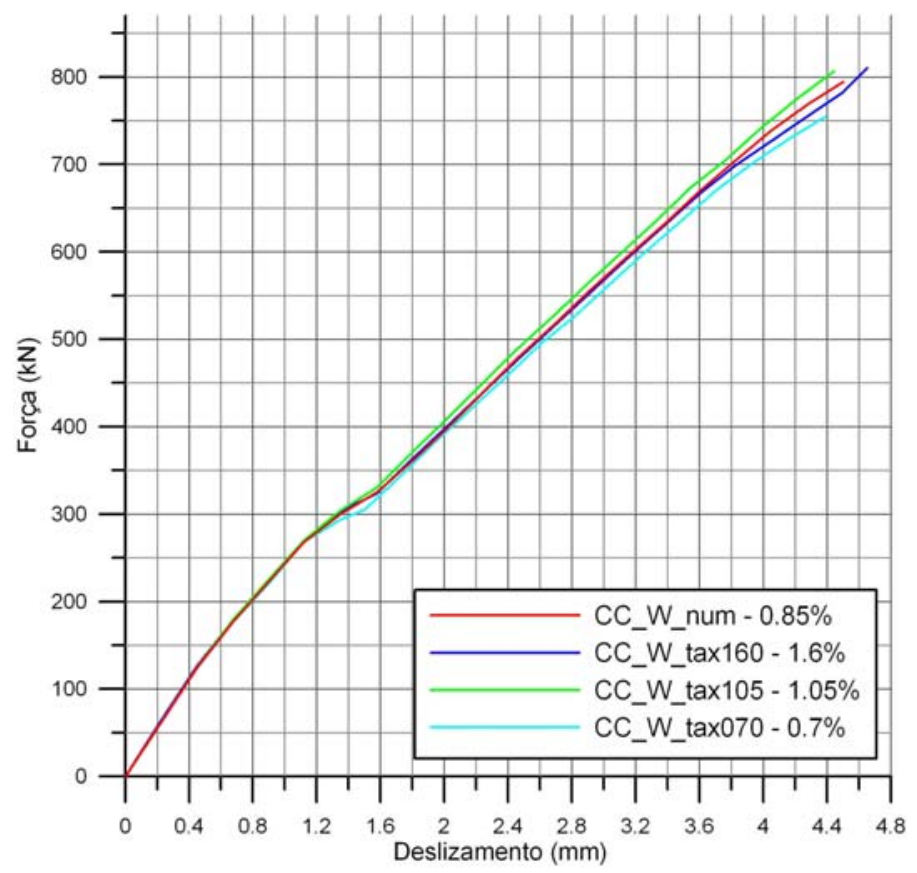

Figura 6-27 - Deslocamento aplicado e reação nos modelos numéricos

O modelo CC_W_num070 apresentou baixa resistência, já que tinha menor taxa de armadura que os demais modelos analisados. A partir do aumento da taxa de armadura, houve um pequeno ganho de resistência. O comportamento das armaduras nestes modelos pode ser observado por meio da análise das deformações nas mesmas. A Figura 6-28 mostra o comportamento das armaduras perante a força aplicada.

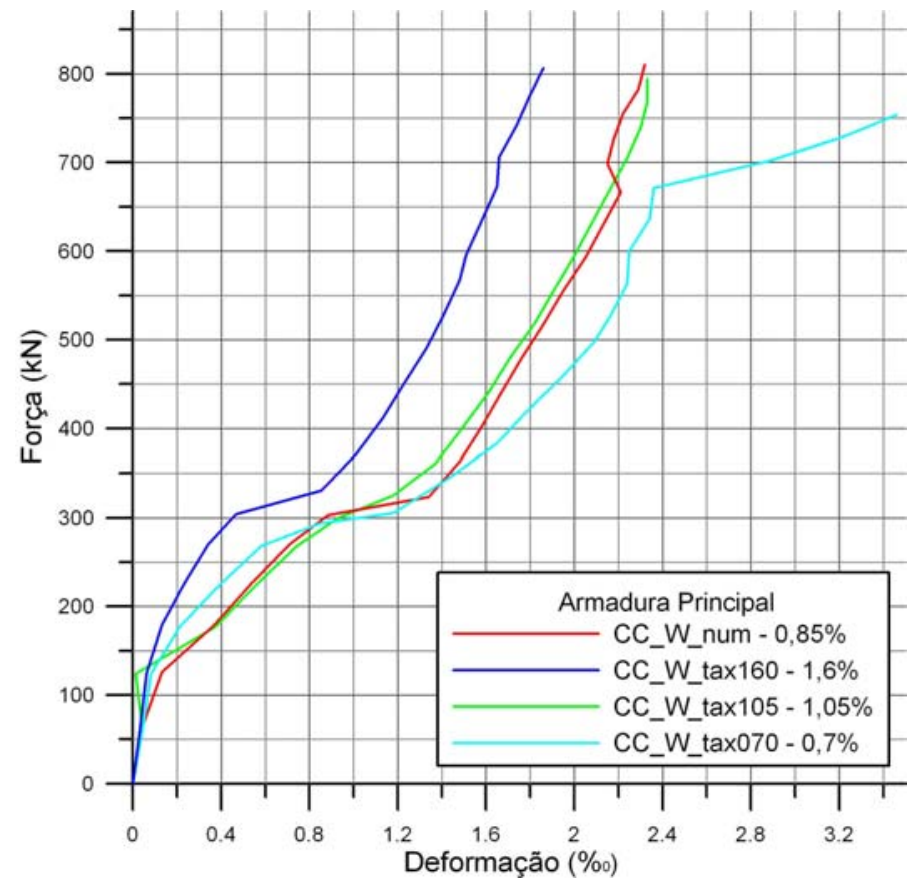

Figura 6-28 - Deformação das armaduras - Variação da taxa de armadura 
A Figura 6-28 indica que a ruptura de todos os modelos de ligação ocorre por plastificação das armaduras, a menos do modelo CC_tax160, que não atingiu a ruína para um carregamento maior devido a problemas de convergência que não foram sanados. O modelo CC_W_tax070 apresentou plastificação excessiva nas armaduras devido à pequena taxa de armadura; isto explica a baixa resistência deste modelo de ligação. Conclui-se, pelos gráficos mostrados anteriormente, que o acréscimo de armadura adiciona rigidez ao modelo, sendo este também um parâmetro importante controlado pelas armaduras da laje de concreto.

Quanto ao deslizamento relativo do concreto, foi constatado que o acréscimo das armaduras também influenciou este parâmetro. Acredita-se que o acréscimo de rigidez devido ao acréscimo na taxa de armadura contribua neste aspecto e também na transferência de tensões entre os dois materiais. A Figura 6-29 mostra o deslizamento relativo entre aço e concreto nos modelos analisados.

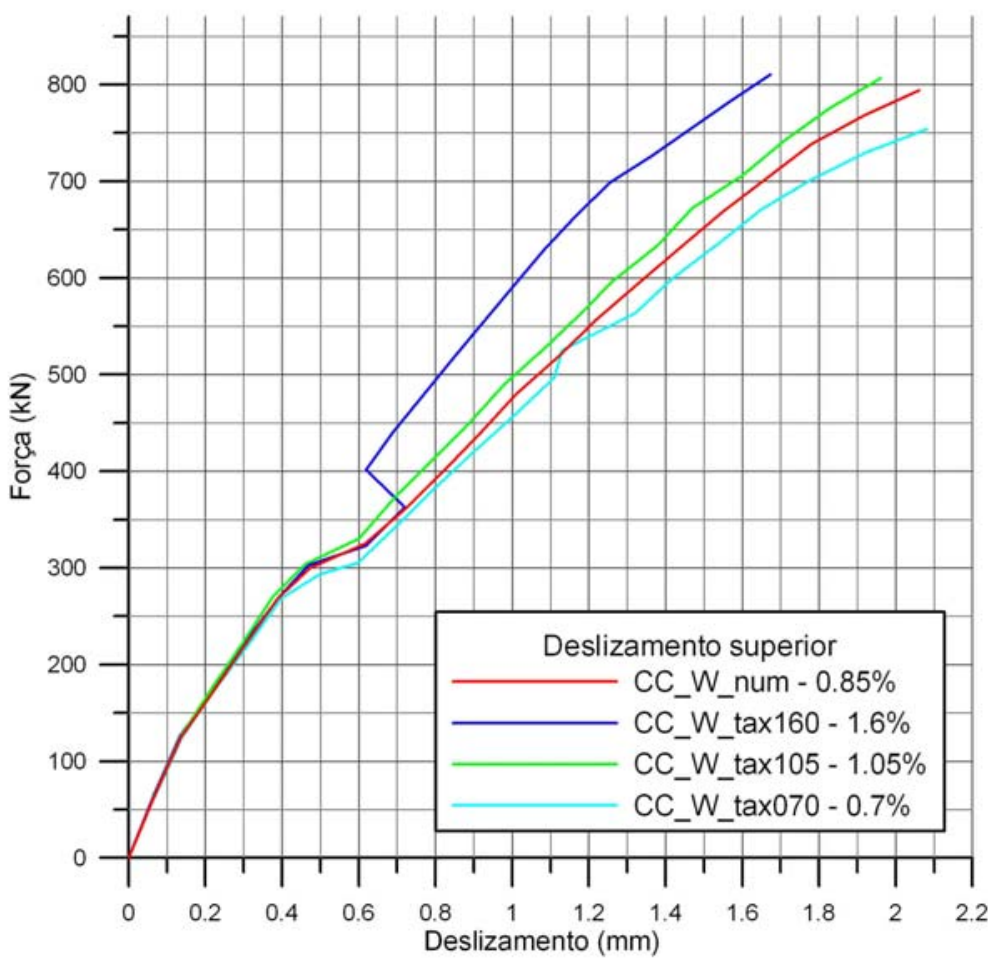

Figura 6-29 - Deslizamento relativo dos modelos numéricos 
O acréscimo na taxa de armadura influenciou o deslizamento relativo, mas não de maneira significativa. Para o modelo com a maior taxa de armadura ocorreram valores de deslizamento relativamente superiores aos verificados nos demais modelos. Acredita-se que a taxa de armadura não seja um parâmetro significante quanto ao deslizamento relativo do concreto, apesar da sua alta influência na rigidez do modelo.

\subsubsection{Análise da influência da ancoragem das armaduras}

Na análise experimental e numérica do modelo de ligação proposto, foi possível notar que as armaduras localizadas na extremidade da laje foram as mais solicitadas e, consequentemente, os componentes preponderantes para o comportamento mecânico, sendo que as armaduras presentes na região central da laje foram pouco solicitadas. Desta forma, visando melhorar isto, foram idealizados dois modelos nos quais houve variação do posicionamento das armaduras centrais, de forma que pudessem ser mobilizadas para a capacidade resistente da ligação.

No primeiro modelo (CCW_ANC1), a opção foi o prolongamento das armaduras centrais, de forma que estas atravessassem o pilar misto. Para o segundo modelo (CC_W_ANC2), as armaduras centrais foram prolongadas de forma a circundar o pilar misto. A continuidade das armaduras na laje destes dois modelos poderia melhorar o desempenho da ligação mista, a partir do melhor aproveitamento da resistência destes elementos. A Figura 6-30 mostra um esquema indicando os dois modelos idealizados. 


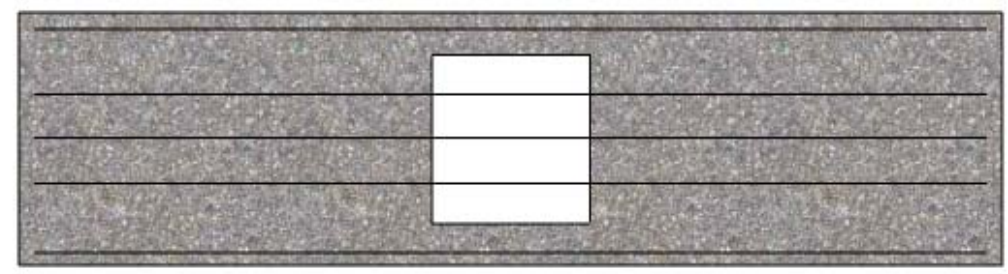

a) CC_W_ANC1

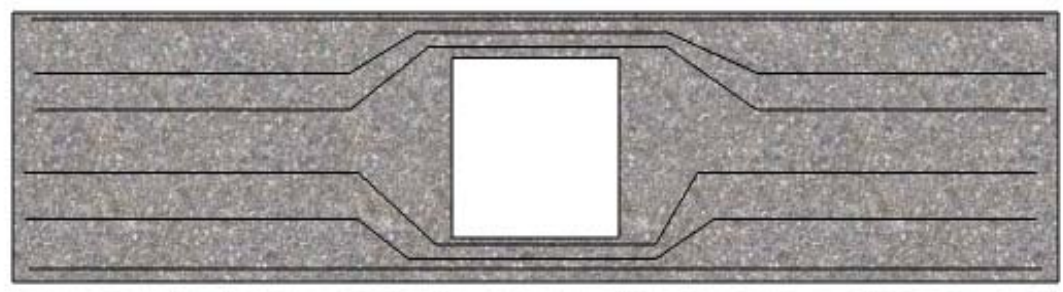

b) CC_W_ANC2

\section{Figura 6-30 - Esquema da ancoragem das armaduras nos modelos numéricos}

O maior beneficio no uso da configuração do segundo modelo (CC_W_ANC2) seria na praticidade de execução, quando comparada ao modelo anterior. É necessário salientar que a taxa de armadura nos dois modelos permaneceu a mesma, mas no modelo CC_W_ANC1 houve o prolongamento das armaduras e, no modelo CC_W_ANC2, o deslocamento da armadura concentrando toda a área na borda da laje, conforme indicado na Figura 6-30.

Quanto à rigidez da ligação, a mudança do esquema de ancoragem das armaduras não pareceu modificar significativamente o comportamento. Isto pode ser evidenciado pelo gráfico de Força aplicada vs. Deslocamento, apresentado na Figura 6-31.

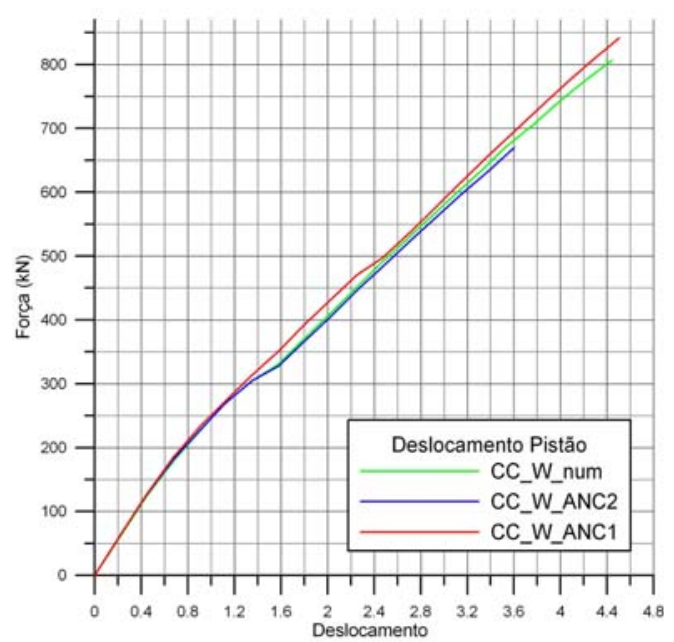

Figura 6-31 - Força aplicada versus deslocamento do modelo 
A modificação da ancoragem e da distribuição das armaduras não resultou em alteração do comportamento quanto à rigidez. Quanto à resistência, o modelo CC_W_ANC1 apresentou ganho de resistência, mas o modelo CC_W_ANC2 não apresentou bons resultados, sofrendo ruptura prematura para uma carga em torno de 670 kN. Na Figura 6-32 são apresentados os resultados de deformações da armadura e estes são comparados com o modelo numérico final (CC_W_num); os resultados são apresentados em função da deformação axial da armadura localizada mais externamente.

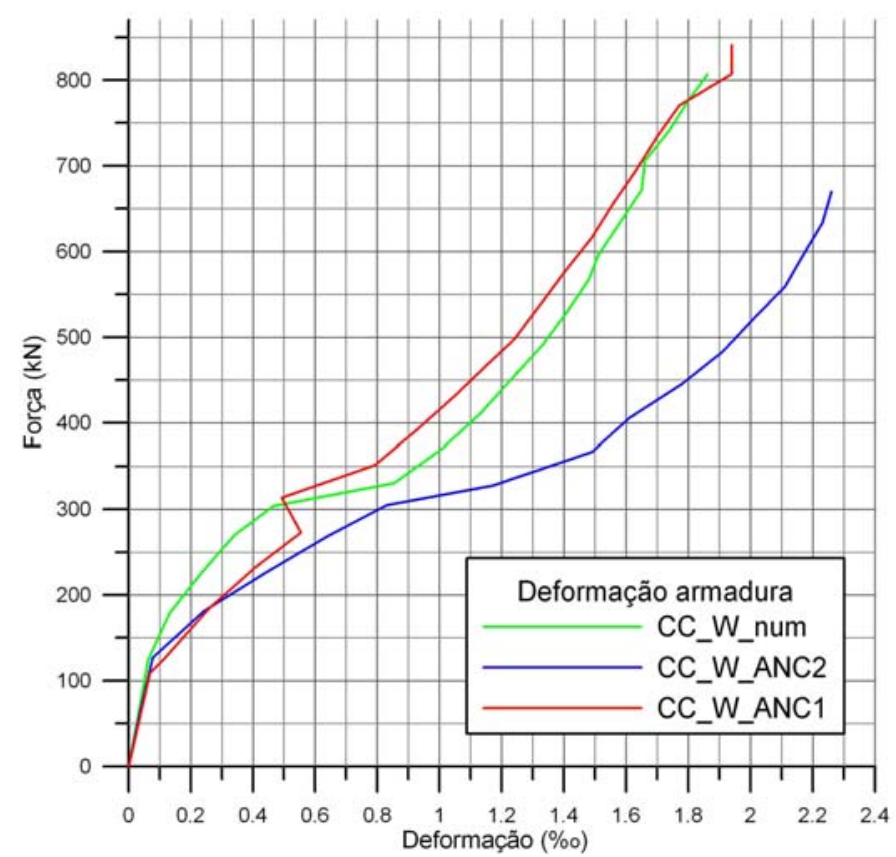

Figura 6-32 - Deformação das armaduras com a variação da ancoragem

O modelo CC_W_ANC2 não apresentou bom comportamento para as armaduras, embora a concentração de armaduras na extremidade tenha diminuído consideravelmente as suas deformações, a ausência de armaduras na região central da laje ocasionou a ruptura prematura.

O modelo CC_W_ANC1 apresentou comportamento melhor quando comparado ao modelo numérico final CC_W_num, mas o prolongamento das armaduras aumentou pouco a resistência final da ligação. Apesar de um melhor comportamento, o fator preponderante para 
a resistência do modelo continuou sendo a armadura localizada na borda da laje, também para este caso.

\subsubsection{Resistência do concreto}

A variação da resistência do concreto da laje também foi avaliada, isto porque foi utilizado um concreto com classe de resistência não usual nos modelos experimental e numérico. Desta forma, visando avaliar a influência deste parâmetro foi considerada a variação da resistência do concreto de $50 \mathrm{MPa}$ para $25 \mathrm{MPa}$.

Para o modelo experimental, acreditava-se que o uso de um concreto de maior resistência não traria influência significativa para o comportamento da ligação, já que a laje de concreto seria tracionada e as armaduras da laje seriam o componente preponderante no comportamento.

Para o modelo numérico foi percebida uma modificação de comportamento com a variação da resistência, provavelmente pela diminuição da resistência à tração do concreto e pela influência do cisalhamento, já que a ligação é solicitada, preponderantemente, por esforço cortante.

O baixo desempenho do modelo com concreto de resistência inferior ficou evidenciado na Figura 6-33, na qual a ligação com laje de 25 MPa (CC_W_fck25) apresentou maiores deformações na armaduras para cargas menores e, consequentemente, ruptura prematura. 


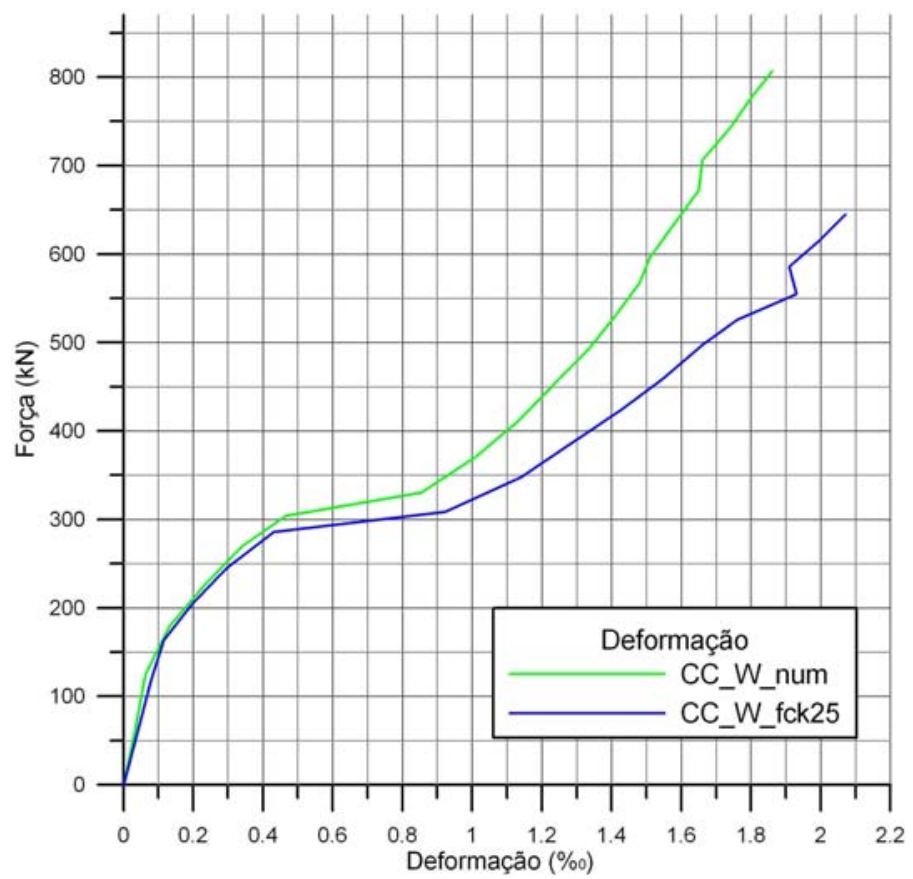

Figura 6-33 - Deformação das armaduras com a variação da resistência do concreto

Quanto à rigidez, o modelo CC_W_fck25 apresentou menor rigidez, mas a diferença não foi tão significativa. A Figura 6-34 mostra o deslocamento aplicado versus a reação de apoio. A resistência do concreto não interferiu na rigidez, mas a deformação excessiva da armadura ocasionou a ruptura da ligação para uma carga de 645 kN.

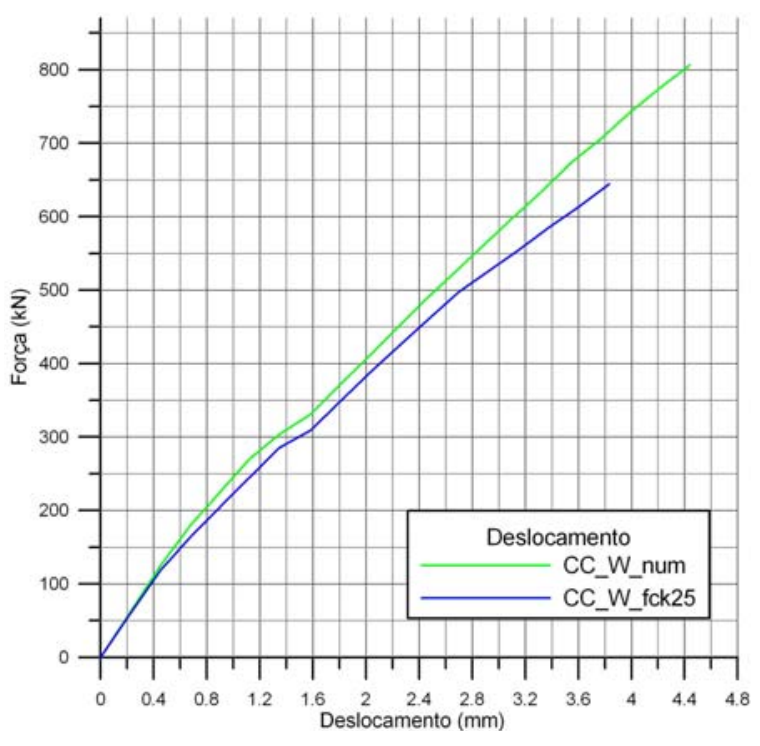

a) Deslocamento dos modelos numéricos

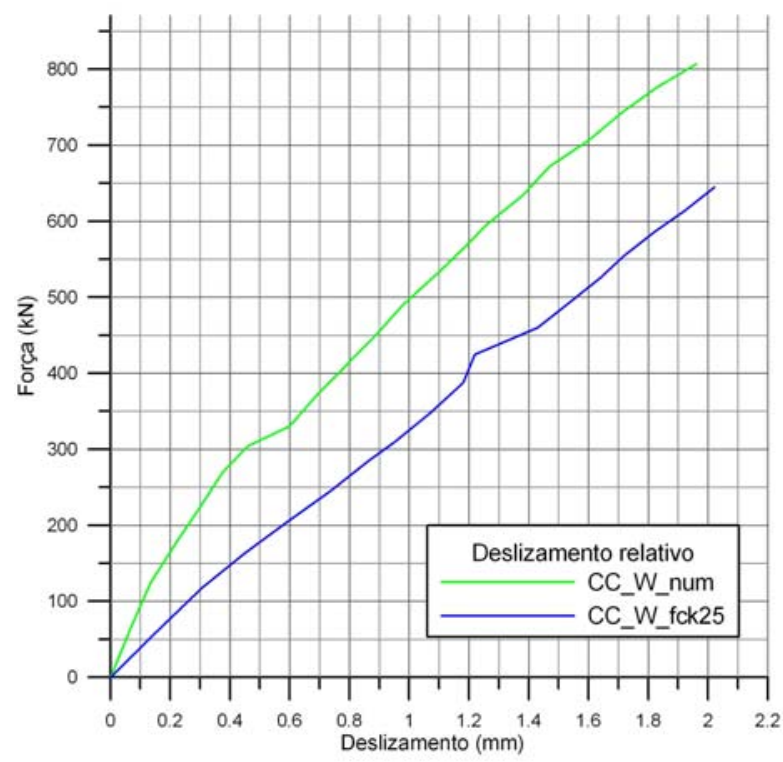

b) Deslizamento relativo do concreto

Figura 6-34 - Deslocamento e deslizamento relativo do concreto 


\subsection{Considerações finais}

Os resultados do modelo numérico quando confrontados com os resultados experimentais foram bastante satisfatórios, principalmente nas etapas iniciais de carregamento. Para as etapas finais, no entanto, em alguns pontos os resultados se distanciaram bastante dos obtidos experimentalmente. Acredita-se que efeitos localizados inerentes à análise experimental tenham mascarado estes resultados e o alto grau de nãolinearidade do modelo tenha contribuído de forma negativa.

Apesar desta diferença nas etapas finais do carregamento, os resultados apresentaram coerência e boa representatividade. Foi possível confirmar, através da análise numérica, que as armaduras são, de fato, o componente determinante para o comportamento da ligação mista.

Quanto à simulação numérica da aderência utilizando elementos de interface com propriedades “bond-slip”, pareceu um procedimento bastante adequado, pois apresentou facilidade de convergência e os resultados da transferência de tensões foram bastante satisfatórios.

A análise paramétrica possibilitou ampliar algumas conclusões. A variação da taxa de armadura possibilitou um aumento de resistência e desempenho da ligação mista.

Fica claro nos resultados que a armadura localizada na borda é preponderante para a resistência deste tipo de ligação, pois, em todos os modelos, a ruptura ocorreu neste componente.

A modificação do tipo de ancoragem não apresentou resultados animadores. O aproveitamento das armaduras centrais para circundar o pilar misto prejudicou o desempenho da ligação como um todo. O prolongamento das armaduras através do pilar misto melhorou o desempenho da ligação, mas, também para este caso, a ruptura ocorreu por deformação 
excessiva da armadura localizada na borda da laje, levando a concluir que este tipo de ancoragem só é eficaz se associado ao aumento da taxa de armadura. 


\section{Capítulo 7}

\section{Aspectos Conclusivos}

\subsection{Considerações finais}

\subsubsection{A respeito do tema e da revisão bibliográfica}

A revisão bibliográfica e a observação das diversas fontes consultadas a respeito do tema possibilitaram algumas considerações quanto ao assunto abordado e estas são relatadas a seguir:

- A união de aço e concreto na forma do pilar misto preenchido traz vários ganhos do ponto de vista estrutural, econômico e construtivo. Os efeitos benéficos do confinamento do concreto e a diminuição de problemas de flambagem no perfil tubular são exemplos claros destes ganhos estruturais.

- A grande maioria dos trabalhos publicados a respeito dos pilares mistos é de caráter experimental e mostram grande eficiência do sistema. Os códigos normativos, entretanto, ainda negligenciam alguns dos efeitos benéficos do sistema, prejudicando sua popularização.

- Outro beneficio do uso do pilar misto é a industrialização do processo construtivo, característica bastante providencial para o seu uso visando diminuir o desperdício de materiais (o uso de fôrmas quando comparado a pilares de concreto) e inserir o sistema construtivo no conceito de desenvolvimento sustentável. 
- Na literatura a respeito da ligação do pilar misto com a viga de aço podem ser encontrados diversos detalhes de ligação. A falta de padronização dos detalhes de ligação e de códigos normativos para seu dimensionamento e verificação pode ser a razão para que estes estudos não sejam direcionados para um objetivo comum, prejudicando a evolução do conhecimento a respeito.

- Dos detalhes de ligação viga-pilar misto nota-se que as ligações externas (ligação direta no perfil tubular) são as mais simples de serem executadas e possuem um baixo custo de execução, mas têm como desvantagem a baixa rigidez e a possibilidade de uma ruptura prematura. Em contrapartida, as ligações que apresentam melhor desempenho são as ligações internas (com ancoragem de algum elemento no núcleo de concreto), que na sua grande maioria são ligações com alto custo e que apresentam diversos problemas de execução.

- A importância da aderência nos pilares mistos preenchidos é um fator importante e citado por diversos autores, sendo responsável por melhorar a rigidez e a ductilidade do elemento misto. O principal problema é a caracterização da aderência entre o concreto e o tubo de aço. Além do comportamento da aderência ser de grande variabilidade, a forma de caracterizar este comportamento com ensaios do tipo "push-out” não é a ideal, pois este tipo de ensaio negligencia a rotação da ligação (região de maior interesse).

- Os modelos desenvolvidos por diversos autores para realizar a modelagem numérica da aderência nos elementos mistos tem apresentado uma evolução natural com o passar dos anos. Colaboram para isto a introdução de novas técnicas de modelagem e de elementos que permitem simular o fenômeno da aderência de forma mais realista. A tendência de uso de elementos de interface para a 
modelagem deste comportamento é notada pelo grande número de trabalhos recentes a esse respeito.

- O estudo das ligações mistas está bastante consolidado já que foram realizados ao longo dos últimos anos estudos experimentais em diversos países da União Européia, no Japão, na Austrália e nos EUA, e muitos dos conceitos a respeito destes elementos já se encontram nos últimos códigos normativos.

- Com a análise dos trabalhos experimentais da literatura, foi possível comprovar a influência da armadura da laje no comportamento geral (rigidez, ductilidade e resistência) das ligações mistas. Parâmetros como a taxa de armadura, a ancoragem e o arranjo da armadura são preponderantes no desempenho das ligações mistas. Grande parte dos estudos realizados se refere a determinados detalhes de ligações. Ligações inovadoras além de não estares normalizados, são abordadas de forma superficial nos trabalhos científicos.

- Além da armadura da laje, outros parâmetros merecem importância e são analisados nos estudos experimentais sobre ligações mistas disponíveis na literatura, como o grau de interação entre a laje de concreto e a viga de aço, e a posição do primeiro conector de cisalhamento em relação à face do pilar.

- A influência do pilar no comportamento das ligações mistas é negligenciada na literatura, já que a contribuição para a ruptura é insignificante. Neste sentido são encontradas na literatura e em códigos normativos formulações que consideram a contribuição de pilares mistos revestidos para a rigidez na ligação mista, mas praticamente não há trabalhos com o uso de pilares mistos preenchidos neste tipo de estudo. 
- Finalmente, foi observado que, em relação às ligações mistas, são escassos os trabalhos de modelagem numérica.

\subsubsection{A respeito da análise experimental}

Da análise feita a partir da investigação experimental pôde-se concluir que:

- Os três modelos físicos analisados tiveram comportamento semelhante, com uma diferença relevante foi verificada entre o modelo CC_W e os demais.

- O uso dos conectores de cisalhamento no pilar misto não interferiu de forma significativa no comportamento do modelo. Entretanto, tais conectores são necessários, pois melhoram a capacidade de transferência de forças entre o concreto e o aço do pilar misto, e funcionam como uma reserva de resistência de ligação.

- Os modelos com conectores de cisalhamentos apresentaram desempenho superior quanto à transferência de forças entre o núcleo de concreto e o perfil de aço, mas este fator não influenciou o modo de ruptura do modelo. Entretanto, o modelo CC_W, que não possuía conectores de cisalhamento no pilar misto, apresentou deslocamento muito superior quando comparado aos demais modelos.

- A viga de aço não teve influência significativa no comportamento da ligação mista uma vez que a ruína foi caracterizada por escoamento da armadura da laje. Entretanto, foram registradas grandes deformações nas mesas comprimidas. Seria interessante avaliar a influência da viga de aço no comportamento da região de ligação, principalmente no que se refere à variação da altura, pois aumentar a altura da viga resulta em aumento do braço de alavanca. 
- Os conectores de cisalhamento foram determinantes na transferência de esforços do pilar misto para a ligação, já que houve mudança no comportamento da linha neutra entre o modelo CC_W e os modelos com conectores ou cantoneiras.

- A presença da laje de concreto armado influenciou significativamente o comportamento dos modelos. O fator preponderante na resistência da ligação foi a armadura de flexão da laje. Isto porque, a partir da plastificação das armaduras, os modelos passam a não apresentar ganho de resistência. Para avaliar melhor este aspecto seria necessário ensaiar um modelo com maior taxa de armadura para mobilizar os outros componentes da ligação e ampliar as conclusões a respeito do tema, embora a situação representada seja a mais usual.

- As armaduras longitudinais posicionadas na extremidade da ligação foram as mais solicitadas, enquanto que as armaduras localizadas próximas à viga não contribuíram para a resistência e a rigidez da região de ligação. Talvez a ancoragem destas armaduras no pilar misto ou a sua distribuição de forma a circundar o pilar misto possam aumentar sua contribuição para a ligação e melhorar seu desempenho

- O modo de ruína foi caracterizado pelo escoamento das armaduras da laje e este é o modo de falha ideal para o modelo estudado. Os outros componentes do modelo permaneceram com sua segurança preservada. Para este tipo de modelo, prefere-se que a ruptura realmente aconteça na laje de concreto, tanto pela ruptura dúctil como pela segurança global do restante da estrutura e pela capacidade de redistribuição dos esforços.

- A comparação dos resultados obtidos neste trabalho com aqueles obtidos por SILVA (2006) permitiu avaliar que a inclusão da laje torna o modelo mais realista 
e com um desempenho superior. Salienta-se que no estudo realizado por SILVA (2006) o modo de ruptura da ligação aconteceu de forma prematura e de modo não ideal. Desta forma acredita-se que foram cumpridos os objetivos iniciais da análise experimental através da inclusão da laje na ligação com parafusos passantes.

\subsubsection{A respeito da análise numérica}

Em relação à análise numérica foram observadas as seguintes conclusões:

- A opção pelo uso de elementos de interface em substituição aos elementos de superfície de contato para a simulação da aderência mostrou-se adequada, já que diversas vantagens resultaram de seu uso, como a facilidade de convergência e a simplicidade de aplicação.

- O modelo constitutivo do concreto baseado na mecânica da fratura mostrou-se interessante, pois possibilitou a calibração do modelo numérico com resultados experimentais e com isso foi possível observar características de comportamento (fissuração) não possibilitadas por outros modelos constitutivos. Entretanto, percebeu-se a excessiva sensibilidade do modelo de concreto quanto à fissuração.

- O modelo numérico final, apesar de simplificado, apresentou diversos problemas de convergência e de custo computacional, mas apesar destas dificuldades os resultados foram satisfatórios.

- Apesar da diferença de alguns resultados da análise numérica em relação aos resultados experimentais, principalmente nas etapas finais de carregamento, o modelo numérico se apresentou coerente e com resultados bastante satisfatórios. 
- Os resultados da análise numérica demonstraram que as armaduras, de fato, é o principal componente da ligação, o que também foi observado na análise experimental. No modelo numérico foi observada a plastificação da armadura posicionada na borda da laje nas etapas finais de carregamento.

- A transferência de tensões entre o perfil tubular e o concreto pôde ser observada na análise numérica. Percebeu-se que este parâmetro apresentou bom comportamento, fato que não ocorre em uma análise experimental devido à variabilidade do fenômeno da aderência. O uso dos elementos de interface possibilitou este bom comportamento.

- O modelo numérico não foi capaz de captar os efeitos localizados no comportamento da viga metálica. Apesar destes efeitos terem sido presenciados na análise experimental; entretanto, este fator não causou diferenças significativas de comportamento entre o modelo numérico e o experimental.

- A análise paramétrica realizada com o modelo numérico e considerando, a variação da taxa de armadura, indicou que a armadura da borda da laje foi o elemento preponderante na ruptura. Com o acréscimo da taxa de armadura houve um aumento da resistência da ligação. Acredita-se que uma taxa de armadura muito elevada pode possibilitar a mobilização de outros componentes da ligação, podendo levar a outros modos de ruptura.

- A modificação da forma de distribuição da armadura na análise paramétrica implica em mudança de comportamento do modelo, mas esta mudança não se refletiu no modo de ruptura, que continuou sendo governada pelo escoamento da armadura localizada na borda da laje. 
- O modelo numérico CC_W_ANC1 apresentou desempenho superior ao modelo numérico final. O prolongamento das armaduras centrais por toda a laje aumentou levemente a resistência e a rigidez da ligação, mas esta diferença não foi significativa, pois a ruptura ocorreu da mesma forma observada nos outros modelos.

- O modelo numérico CC_W_ANC2 não apresentou o desempenho almejado, com a ruptura ocorrendo de forma prematura. A ausência das armaduras centrais pode ter ocasionado a instabilidade numérica do modelo, devido à deformação por tração do concreto da laje na região central.

- A diminuição da resistência do concreto à compressão na análise paramétrica realizada via modelo numérico, reduziu a resistência e a rigidez da ligação. Acredita-se que o mesmo não ocorreria em uma análise experimental. A sensibilidade numérica do modelo constitutivo do concreto pode ter ocasionado esta perda de resistência.

\subsection{Conclusão}

O objetivo inicial do trabalho era investigar a influência da laje de concreto na transferência de forças no modelo de ligação viga - pilar misto proposto por PRIAN e MCLELLAN (1996). Esta ligação foi estudada em trabalhos anteriores como em DE NARDIN (2004) e SILVA (2006). No estudo realizado por SILVA (2006), a ruptura prematura e de forma inadequada sugeriam a continuidade do estudo com a inclusão do elemento de laje no modelo, a fim de simular um comportamento mais realista da região de ligação. 
O objetivo do trabalho foi alcançando, sendo comprovado que a inclusão da laje de concreto insere um comportamento diferente do apresentado do modelo estudado por SILVA (2006). A ruptura considerando a laje ocorreu por plastificação das armaduras, e de forma dúctil.

Além de cumprir o objetivo inicial, outros aspectos importantes foram concluídos através da análise experimental e numérica, podendo contribuir para estudos realizados posteriormente, dando continuidade à pesquisa.

Vale salientar que este trabalho foi proposto para dar continuidade a pesquisas realizadas anteriormente, e que certamente serão realizados estudos posteriores para dar continuidade ao modelo de ligação apresentado.

\subsection{Sugestões para futuros trabalhos}

- Analisar experimentalmente a ligação proposta com variação da taxa de armadura e de formas de ancoragem.

- Investigar a influência da largura da laje de concreto em modelos de ligação similares ao proposto neste trabalho

- Investigar teoricamente o modelo de ligação com o uso do método dos componentes, avaliando a contribuição do pilar misto preenchido na rigidez da ligação.

- Estudar mais o modelo numérico, avaliando o uso de diversas estratégias para a modelo de interface aço-concreto, permitindo assim uma visão mais ampla do modelo ideal para a ligação. 
- Realizar um estudo numérico-experimental para calibrar curvas do tipo "bondslip” para serem utilizadas na simulação da aderência aço-concreto em elementos mistos, para os diversos elementos e com a variação das propriedades dos materiais.

- Investigar um modelo numérico mais simplificado da ligação a fim de possibilitar a realização de uma análise paramétrica mais ampla.

- Analisar a influência da relação entre a força cortante e o momento na ligação estudada, já que, para os diversos estudos realizados foi mantido o mesmo vão da ligação. 


\section{Referências Bibliográficas}

AHMED, B.; NETHERCOT, D. A. (1996) Effect of High Shear on the Moment Capacity of Composite Cruciform Endplate Connections. Journal of Construct Steel Ressearch Vol. 40, No. 2, pp. 129-163.

ALOSTAZ, Y. M.; SCHNEIDER, S. P. (1996). Analytical behavior of connections to Concrete-filled steel tubes. Journal of Constructional Steel Research, v.40, No 2 p.95-127.

AMERICAN SOCIETY FOR TESTING AND MATERIALS (1992). ASTM A370: Standard test methods for tension testing of metallic materials (metric). Philadelphia.

AN, L.; CEDERWALL, K. (1996). Push-out Tests on Studs in High Strength and Normal Strength Concretet. Journal of Constructional Steel Research, v.36, No 1 p.15-29.

AMERICAN INSTITURE OF STEEL CONSTRUCTION; (2005). AISC/ANSI 360 Specification for Structural Steel Buildings. Chicago

ANDERSON, D.; ARIBERT, J. M.; BODE, H.; KRONENBURGER, H. J.; (2000). Design rotation capacity of composite joints. The Structural Engineer Volume 78/No 6. March 2000. P. 25-29

ARIBERT, J.-M. (1995). Influence of slip on the shear connection on composite joint behavior. In: Connections in steel strucutures III - Behavior, strength e design - Procedings. Trento, Italy, 1995.

ASHADI, H.; BOUWKAMP, J. G. (1995). Behaviour of hybrid composite structural earthquake resistant joints In: EUROPEAN CONFERENCE ON EARTHQUAKE ENGINEERING, 10th Proceedings. Balkema. p.1619-1624.

ASSOCIAÇÃO BRASILEIRA DE NORMAS TÉCNICAS (2007). Projeto de revisão NBR 8800: Projeto de estruturas de aço e de estruturas mistas aço-concreto de edifícios. Rio de Janeiro.

AZIZINAMINI, A.; SHEKAR, Y.; SAADEGHVAZIRI, M. (1995). Design of through beam connection detail for circular composite columns. Engineering Structural, v. 17, n.3, p.209213.

BEUTEL, J.; THAMBIRATNAM, D.; PERERA, N. (2002) Cyclic behaviour of concrete filled steel tubular column to steel beam connections. Engineering Structures. Vol 24 (2002). p 29-38 
BERNUZZI, C.; NOÉ P.; ZANDONINI, R. (1991). Semi-rigid composite joints: experimental studies. In: Connections in steel strucutures II - Behavior, strength e design Procedings. Pesnsilvania, USA, 1991.

CEDERWALL, K.; ENGSTROM, B.; GRAUERS, M. (1990). High-strength concrete used in composite columns. In: HESTER, W. T., (Ed.) High-strength concrete: second international symposium. Detroit, ACI. p.195-214. (ACI SP-121).

DE NARDIN, S. (2003). Pilares mistos preenchidos: estudo da flexo-compressão e de ligações viga-pilar. São Carlos. 323 p. Tese (doutorado) - Escola de Engenharia de São Carlos, Universidade de São Paulo.

EUROPEAN COMMITTEE OF STANDARDDIZATION (1994). Env 1994-1-1: Eurocode 4: Design of composite steel and concrete structures. Part 1.1: General rules and rules for buildings. Brussels.

FRANCE, J.E. ; DAVISON, J.B. ; KIRBY, P.A. (1999a). Strength and rotationalstiffness of simple connections to tubular columns using flowdrill connectors. Journal of Constructional Steel Research, v.50, p.15-34.

FRANCE, J.E. ; DAVISON, J.B. ; KIRBY, P.A. (1999b). Moment-capacity and rotational stiffness of endplate connections to concrete-filled tubular columns with flowdrilled connectors. Journal of Constructional Steel Research, v.50, p.35-48.

FU, F.; LAM, D. (1996). Effect of High Shear on the Moment Capacity of Composite Cruciform Endplate Connections. Journal of Construct Steel Ressearch. Vol. 40, No. 2, pp. 129-163.

FUJIMOTO, T.; MUKAI, K.; NISHIYAMA, I.; SAKINO, K. (2004). Behavior of Eccentrically Loaded Concrete-Filled Steel Tubular Columns. JOURNAL OF STRUCTURAL ENGINEERING. ASCE / FEBRUARY 2004. p. 203-212.

GARDNER, A. P.; GOLDSWORTHY, H. M. (2004). Experimental investigation of the stiffness of critical components in a moment-resisting composite connection. Journal of Constructional Steel Research Vol. 61 (2005). P. 709-726.

GREEN, T. P.; LEON, R. T. RASSATI, G. A. (2004). Bidirectional Tests on Partially Restrained, Composite Beam-to-Column Connections. Journal Of Structural Engineering Asce / February 2004. P. 320-327.

HAJJAR, J. F.; SCHILLER. P. H.. MOLODAN, A. (1998). A distributed plasticity model for concrete-filled steel tube beam columns with interlayer slip. Engineering Structures, Vol. 20, No. 8, pp. 663-676,

HAN, L-H; YAO, G-H. (2003a). Influence of concrete compaction on the strength of concrete-filled steel RHS columns. Journal of Constructional Steel Research Vol. 59 (2003) P. 751-767 
HAN, L-H; YAO, G-H. (2003b). Behaviour of concrete-filled hollow structuralsteel (HSS) columns with pre-load on the steel tubes. Journal of Constructional Steel Research Vol. 59 (2003) P. 1455-1475.

HIGGINS, C.; MITCHELL, H. (2001). Behavior Of Composite Bridge Decks With Alternative Shear Connectors. Journal Of Bridge Engineering January/February 2001. P. 17-22.

HUANG, C. S.; YEH, Y. K.; LIU, G. Y.; HU, H. T.; TSAI, K. C.; WENG, Y. T.; WANG, S. H.; WU, M. H. (2002). Axial load behavior of stiffened concrete-filled steel columns. Journal of Structural engineering, v.128, n.9, p.1222-1230, September.

JEONG, Y. J; KIM, S. H; AHN J. H. (2005). Partial-interactive behaviour of steel-concrete members under static and fatigue loadings. Magazine of Concrete Research, 2005, 57, No. 5, June, 289-300

JOHANSSON, M. GYLLTOFT, K. (2001). Structural behavior of slender circular steelconcrete composite columns under various means of load application. Steel and composite structures. v.1, p.393-410. December.

JOHANSSON, M.; GYLLTOFT, K. (2002). Mechanical behavior of circular steel concrete composite stub columns. Journal of Structural Engineering, V.128, n.8, p.1073-1080, August.

KILPATRICK, E.; RANGAN, B. V. (1999). Tests on high-strength concrete filled steel tubular columns. ACI Structural Journal, V.96, n.2, p.268-274, March-April.

LEON, R. T. (1998). Composite connections. Progress in Structural Engineering and Materials I 998 Vol I(2): p159- 169.

LI, T.Q; NETHERCOT, D.A. LAWSON. R.M. (2000). Required rotation of composite connections. Journal of Constructional Steel Research 56 p151-173.

LIU, D.; GHO, W-M.; YUAN, J. (2003). Ultimate capacity of high-strength rectangular concrete-filled steel hollow section stub columns. Journal of Constructional Steel Research Vol. 59 (2003) P. 1499-1515.

LOH, H. Y.; UY, B.; BRADFORD, M. (1996) Behaviour Of Partial Strength Composite Steel-Concrete Joints Incorporating Various Novel Features (1992)

NETHERCORT, D. A. (1995). Design of composite connections. The Structural Engineer. Vol. 73. No 13. July 1995 P. 218-219.

NETO, J. M. (2007). Análise numérica não-linear de estruturas de concreto armado considerando o fenômeno da aderência entre o aço e o concreto. Campinas. 187 p. Tese (doutorado) - Faculdade de engenharia civil, arquitetura e urbanismo, Universidade estadual de Campinas. 
NISHIYAMA, I; FUJIMOTO, T; FUKUMOTO, T. YOSHIOKA, K. (2004). Inelastic ForceDeformation Response of Joint Shear Panels in Beam- Column Moment Connections to Concrete-Filled Tubes. Journal Of Structural Engineering. February 2004

PARSLEY, M. A.; YURA, J. A.; JIRSA, J. O. (2000). Push-out behavior of rectangular concrete-filled steel tubes. Michigan, Riyad S. Aboutaha and JOSEPH M. BRACCI ed. Composite and Hybrid systems, ACI. P.87-107. (ACI SP-196).

PRION, H. G. L.; McLELLAN, A. B. (1994). Through-bolt connections for concrete-filled hollow structural steel sections. In: ANNUAL TASK GROUP TECHNICAL SESSION 1994. Proceedings. Bethlehem. p.239-250.

PUHALI, R; SMOTLAK, I; ZANDONINI, R. Semi-Rigid Composite Action: Experimental Analysis and a Suitable Model. Journal Construct. Steel Research 15 (1990) 121-151

QUEIROZ, G.; PIMENTA, R. J.; MATA, L. A. C. (2001). Elementos das estruturas mistas aço-concreto. Ed. O Lutador, 336p.

RICLES, J. M.; PENG, S. W.; LU, W. L. (2004). Seismic Behavior of Composite Concrete Filled Steel Tube Column-Wide Flange Beam Moment Connections. Journal Of Structural Engineering Asce / February 2004 P. 223-233.

ROEDER, C. W.; MACRAE, G.; WATERS, C. (2000) Seismic Behavior of Steel Braced Frame Connections to Composite Columns.

SAKINO, K.; NAHAKARA, H.; MORINO, S.; NISHIYAMA, I. (2004). Behavior of Centrally Loaded Concrete-Filled Steel-Tube Short Columns. Journal Of Structural Engineering Asce / February 2004 P. 180-188.

SALARI, M. R.; SPACONE, E. (2001). Finite element formulations of one-dimensional elements with bond-slip. Engineering Structures 23 (2001) 815-826

SALARI, M. R.; SPACONE, E. (2001) Analysis Of Steel-Concrete Composite Frames With Bond-Slip. Journal Of Structural Engineering / November 2001 / P. 1243- 1250

SILVA, R. D. (2006). Estudo da aderência aço-concreto em pilares mistos preenchidos. São Carlos 136 p. Dissertação (mestrado) - Escola de Engenharia de São Carlos, Universidade de São Paulo.

SILVA, L.; SIMÕES, R; CRUZ, P. J. S. (2001) Experimental behaviour of end-plate beamto-column composite joints under monotonical loading. Engineering Structures $231383-$ 1409.

SHAKIR-KHALIL, H. (1993a). Pushout strength of concrete-filled steel hollow sections. The structural engineer, v.71, n.13/6, p.230-233, July. 
SHAKIR-KHALIL, H. (1993b). Resistance of concrete-filled steel tubes to pushout forces. The structural engineer, v.71, n.13/6, p.234-243, July.

SHAMS, M.; SAADEGHVAZIRI, M. ALA; (1997). State of the art of concrete filled steel tubular columns. ACI Structural Journal, v.94, n.5, p.558-571, September/October.

SHANMUGAM, N. E.; LAKSHMI, B. (2001). State of art report on steel concrete composite columns. Journal of Constructional Steel Research, V.57, p. 1041-1080.

SHIM, C.-S.; LEE, P.-G.; YOON, T.-Y. (2004). Static behavior of large stud shear connectors. Engineering Structures. Vol. 26 (2004). P. 1853-1860.

SOH, C. K; CHIEW S. P. DONG, Y. X.; (1999). Damage Model For Concrete-Steel Interface Journal Of Engineering Mechanics / AUGUST 1999. P. 979 -883.

SOH, C. K; CHIEW S. P. DONG, Y. X.; (2002). Concrete-steel bond under repeated loading. Magazine of Concrete Research, 2002, 54, No. 1. P. 35-43

TSCHEMMERNEGG. F. (1992). The Non-linear Behavior of Composite Joints. Journal of Construction Steel Research Vol. 21 (1992). P. 59-70

UY, B. (1998). Ductility, strength and stability of concrete-filled fabricated steel box columns for tall buildings. Structural Design of Tall Buildings, v.7, p.113-133.

UY, B. (2003). High-strength steel-concrete composite columns for buildings. Proceedings of the Institution of Civil Engineers Structures \& Buildings. Vol 156. February 2003 Issue 1. P. 3-14.

VALENTE, I.; CRUZ, P. J. S. (2004). Experimental analysis of Perfobond shear connection between steel and lightweight concrete. Journal of Constructional Steel Research. Vol. 60 (2004). P. 465-479.

VIRDI, K. S.; DOWLING, P. J. (1980). Bond strength in concrete filled steel tubes.IABSE-International Association for Bridge and Structural Engineering, n.03, p.125137, August.

XIAO, Y; CHOO B. S. NETHERCOT, D. A. (1994). Composite Connections in Steel and Concrete. Part I. Experimental Behaviour of Composite Beam-Column Connections. Journal of Construction Steel Research 31 p. 3 - 30.

XIAO, Y; CHOO B. S. NETHERCOT, D. A. (1996). Composite Connections in Steel and Concrete.Part 2 Moment Capacity of End Plate Beam to Column Connections. Journal of Construction Steel Research 31 p. $3-30$

YANKELEVSKY, D. Z; (1985) Analytical Model for Bond-slip Behavior Under Monotonic Loading. Building and Environrnent, Vol. 20, No. 3, pp. 163-168. 
ZANDONINI, R. (1994). Composite Construction Research and Practice: recent developments in Europe. In: ANNUAL TASK GROUP TECHNICAL SESSION 1994, Bethlehem Pennsylvania. Proceedings. Bethlehem, Reports on Current Research Activities. p.251-274.

WANG, Y. C (1999). Test on slender composite columns. Journal Constructional Steel Research, v.49, n.1, p.25-41. 